Historic, Archive Document

Do not assume content reflects current

scientific knowledge, policies, or practices. 

62.19

\section{WILLET'S 1919}

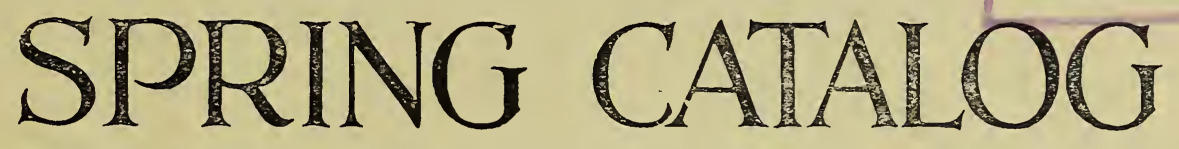

FIELD \& GARDEN SEED FOR THE SOUTH

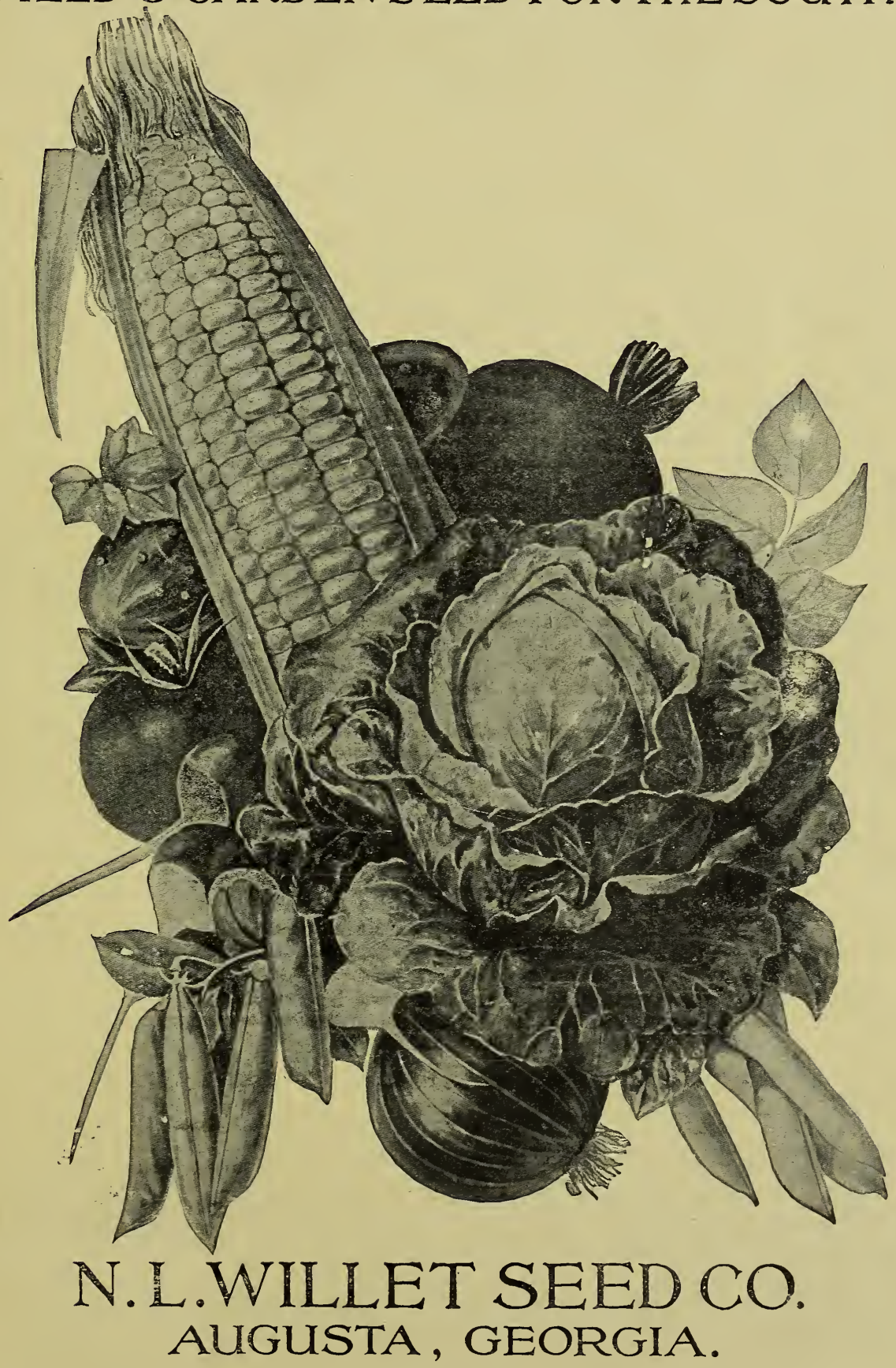




\section{Inoculate Your Alfalfa, Clovers, Cow Peas, Soy Beans, Vetches and all other legume crops with}

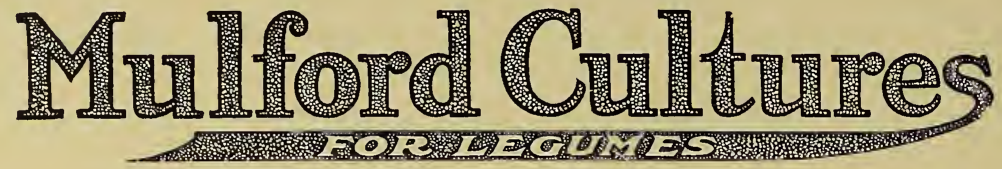

Small Cost

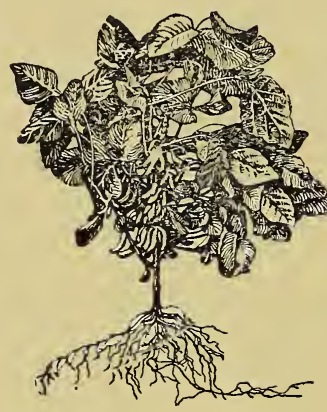

Large Returns

Easy to Use

No Labor Expense

MULFORD CULTURES contain pure tested strains of active, vigorous, nitrogen-fixing bacteria, for inoculating seeds of legumes or soil. Enormous numbers of these very valuable and desirable bacteria are thus available to you in every package of Mulford Culture and may readily be applied to your seed. The sealed bottle insures purity.

\section{Increase Your Crops Improve Your Soil}

LEGUMES OFFER THE BEST-KNOWN MEANS of maintaining soil fertility and rejuvenating overeropped and worn-out fields. They add both humus and nitrogen to your soil and thus increase your yield of wheat, cotton, corn and other non-legume crops.

THE U. S. DEPARTMENT OF AGRICULTURE and many State Agricultural Experiment Stations recommend inoculation of Uninoculated Soy Beans

Inoculated

Photographed on same scale. Plant un right not inoculated-Plant - $\eta$ left inoculated with Mulford Culture for Soy Beans. All other
conditions identical.

THE CONTRAST SPEAKS FOR ITSELF legumes with nitrogen-fixing bacteria to induce a prompt "catch" and increase your yield.

MULFORD CULTURES ARE SCIENTIFICALLY PREPARED and tested by experts, in the biological laboratories of $H . K$. Mulford Company, Philadelphia, U. S. A., with the same degree of care as Mulford Antitoxins, Serums, Vaccines, etc., which are standard all over the world.

Always specify on your order what crop you want to inoculate, as there is a different strain of bacteria for each legume.

ALFALFA

CRIMSON CLOVER

SWEET CLOVER

WHITE CLOVER

RED CLOVFR

ALSIKE CLOVER

Mammoth clover

\section{VETCH}

Yellow Clover

Berseem Clover

COW PEAS

SOY BEANS

Canada Field Peas

PEANUTS

\section{Horse Beans}

VELVET BEANS

Perennial Peas

SWEET PEAS

GARDEN PEAS

GARDEN BEANS
LIMA BEANS

Lupins

Sainfoin

Lespedeza

Beggar Weed

Kudzu

and others. prepared to order and can be supplied in a few days.

\section{PRICES}

MULFORD CULTURES are supplied for the varieties of legumes listed, at the following prices:

5-Acre Size, \$5.00 ("A Dollar per Acre")

1-Acre Size .................................................\$1.50

1-4 Acre Size..

Small Size (Supplied only in 4 varieties,

for Garden Peas, Garden Beans, Lima

Beans and Sweet Peas) .25

(These prices include delivery on freight shipments)

Why buy expensive commercial nitrates when you can grow legume crops and thus increase your yield and at the same time increase the nitrates and enrich and renovate your soil by Nature's own method.

FREE DESCRIPTIVE LITERA TURE SENT UPON REQUEST

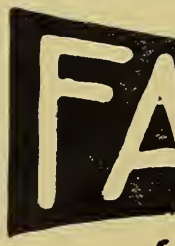

TME STANDARD INOCULATION

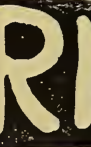
Mor (1)

HICH BRED NITROGEN GATHERING BACTERIA

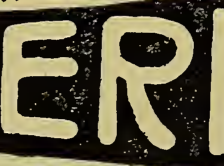

MES

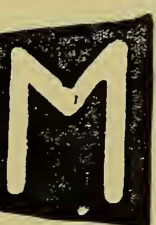

See Legume list above in Mulford's Culture. Farmogerm has been on the market for 10 Years UNIT PRICE TO CUSTOMER Garden Size Bottle

( $1 / 4$ Acre) …........ $\$ 50$ each One-Acre Size Bottle 1.50 “" Five-Acre Bottle........ 5.00 “" 


\section{N. L. WILLET SEED COMPANY}

\section{AUGUSTA, GEORGIA. \\ 1919-SPRING GATALOGUE-1919}

\section{INTRODUCTORY}

THIS CATALOG is informative and in a large and general way rather than the usual seed catalog, which is often only commercial and is only intended to stress and sell certain given seeds on which there is extra profit.

\section{THE "WHLET PLAN" IS TO SATISFY.}

Whether you are a new customer, or a patron of years' standing, we assure you of our earnest co. operation to satisfy you, to keep you satisfied and to retain you as a permanent buyer of "WILLET'S SOUND SEEDS.'

Our aim is to make our business improve, to grow better seeds every year so our customers will have better, more profitable gardens and farms, year after year.

We wish you to feel that we have a greater interest in you than merely filling your orders-we want you to feel that we are as much concerned about the success of your crops on your farm or in your garden as if we were in a partnership with you.

We want to so conduct our business and serve you that you will not only be a customer, but a friend.

We invite you to buy your seeds of us and get the benefits of the "WILLET PLAN." We feel sure that it will form business relations between us of long standing.

\section{WILLET'S SOUND SEEDS ARE TESTED SEEDS.}

Every lot of seeds that we receive is given a careful germinating test to enable us to ascertain its vitality. If any are found low in vitality they are destroyed or used for stock feed. The packets we put up contain seeds of the same good quality as those sold in larger quantities.

We try new varieties before we list them to the public. Many are offered to us each year, but few of them pass the critical tests which we give them. You may feel assured that the sorts listed in this catalog have good recommending qualities. Keep in mind the fact that "WILLET'S SOUND SEEDS" are especially selected for the South.

We thank our old customers for past patronage, and we beg a continuance of the same. We assure every new customer that our best endeavors will be given to orders from themselves. We conduct our business not only on scientific lines, but also on ethical lines. We try to give "best service."

The Willet Medal-The Willet Medal, given for meritorious agricultural work, is the only medal of its kind being given. We will be glad to be put in touch with workers who are deserving of it.

\section{FOR THE AGRICULTURAL STUDENT!}

An Agricultural Encyclopedia-Your farm and garden will be greatly benefited if you will read this catalog from cover to cover. By putting a string in it and hanging it up by the fireplace, you will have a ready reference throughout the year. This book is an agricultural encyclopedia, "and points a thousand ways for agriculture."

Agricultural Paper Subscriptions-For cash-taken by us at Publishers' yearly prices for following Weeklies, Semi-Monthlies, and Monthlies: Southern Cultivator (Ga.) (S.-M.), \$1 Florida Grower (W.), \$1.50; Progressive Farmer (N. C.), (W.), \$1; Southern Fruit Grower (Tenn.), (M.), 50c; Country Gentleman (W.), \$1; Hoard's Dairyman (W.), \$1.15; Breeder's Gazette (W.), \$1.50; Augusta Daily Chronicle, containing Willet's daily "Common Sense Comments," \$8.00. Also Mr. Willet's new book, just out, "The Divinity of the Undivine," \$1.35, postpaid.

N. L. WILLET SEED CO.

\section{INDEX}

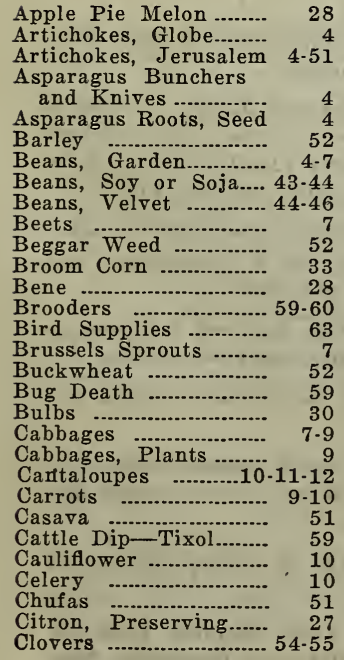

Lawn Mowers and Rollers, etc.............. 30 Lettuce ............................ . 15 Millet, German.............. 48 Millet, Japanese............ 48-49 Millet, Pearl, BrownTop -....................... 48 Milo Maize ..................... 48 Mustard ...................... 15-16 Mulford Cultures,

Front Cover. Inside.

New Things Stressed.- 63 Oats ................................ 52-53 Okra 16
$16-17$

Onion Seed and Sets.. 16-17 Parsley and Parsnip.... 17.18 Peas, Canada Field ... Peas, Cow or Field.... 41-43 Peas, Garden................. 18-19 Peas, Garden................. 18.19 Peanuts ..................... 49-50 Pecan Nuts.................... 52 $\begin{array}{lr}\text { Pepper ........................ } & 19 \\ \text { Planting Calendar... }\end{array}$ Plant Setters................. 9 Potatoes, Draws........... 21 Potatoes, Irish............. 19-20 Potatoes, Sweet.......... 20-21 Pots, Earthenware....... 30 Pots, Earthenware....... $\begin{array}{lll}\text { Poultry } & \text { Feeds.............. } & 62 \\ \text { Poultry Remedies........ } & 62\end{array}$
Poultry Supplies........ 59-62 Pumpkins \& Cushaw.. 21 Rumpkins \& Cushaw.. 21.21 Rafishes Tape................... 21-2 Rape, Essex................... 23-51 Rice, Upland.................... Romaine b...................... 15 Rye ............................... 53 Salsify Spinach .......................... Spinach ...................... $\quad 53$ $\begin{array}{ll}\text { Seed Sowers.................. } & 58 \\ \text { Shallu .......................... } & 48\end{array}$ Shallu ......................... $\quad 48$ Sorghum ......................... 46-47 Spraying Machines...... 59 Squash ......................... 23.24 Sugar Cane, Japanese 49 Sunflower ................... 51 Swiss Chard.................... Tomato .......................... 24-25 Tomato ......................... 24-25

Treosinte Fruit, Orna- 48 Trees, Fruit, Orna-
mentals ................. 30-64

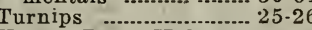
Velvet Bean Huller.... 44 Vetches ....................... 53-54 Water Melons...........26-27-28 Wheat .................. 53

Willet's Manufactures

- Rear Cover, Inside. 


\section{GENERAL INFORMATION AND TERMS OF SALE.}

The Prices Quoted in the Catalog Are Net-We offer nopremiums, discounts - or gratuities. This list cancels all

Remittances should be made by Express Money Order, P. O. Money Order, Bank Draft or Registered Letter. We must decine sending goods C. O. D unless 25 per cent of their value accompanies the order. We do not ship plants C. O. D. Accounts-Parties having no aceount with us-who order goods without remittance-must furnish satisfactory references. Augusta reference preferred.

We Forward as Customers Direct-By express, freight or parcel post. When no shipping instructions are given we send according to our judgment.

We Deliver Free-We will deliver free of expense to buyer all Vegetable and Flower Seed sold by the packet, ounce, and up to 1-4 pound. Purchasers pay transportation on one pound, pints, quarts, pecks, half-bushel, etc. If wanted sent by parcel post add postage as noted below:

We Do Not Guarantee Safe Delivery by parcel post unless sufficient postage is sent to insure, which is only five cents on packages amounting to $\$ 25.00$, as packages lost by mail we can not be responsible for, or make claim unless insured.

Special Express Rates-The American-Railway Express Company gives lowered express rate on seeds as second class. Shipment of 15 pounds seed in a 300 mile radius from Augusta, costs about 40 cents.

Catalog Prices-The prices quoted in this catalog are only those ruling at time it is printed. All Garden Ssed, and especially Field Seed, such as Grains, Clovers and Vetches, etc., are liable to fluctuate in price; and prices follow mar ket conditions and supplics. We will take pleasure at any time in quoting prices on request, or we will fill all orders entrusted to us at as low prices as possible for first-class seeds.

Errors in the Filling of Orders-We use the greatest care in filling, checking and packing orders. Should anything accidentally omitted we will prompty forward same when advised. Keep a dupicate copy of your order.

FOURTH CLASS (Domestic Parcel Post) ZONE RATES

\begin{tabular}{|c|c|c|c|c|c|c|c|c|c|}
\hline \multirow[b]{2}{*}{$\begin{array}{l}\text { Woight, } \\
\text { in } \\
\text { pounds }\end{array}$} & \multirow[b]{2}{*}{ Local } & \multicolumn{8}{|c|}{ ZONES } \\
\hline & & 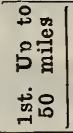 & 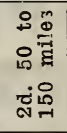 & 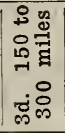 & 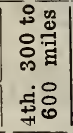 & 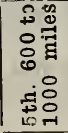 & 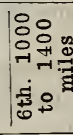 & 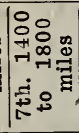 & 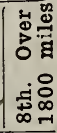 \\
\hline lb. & 0.05 & $\$ 0.05$ & $\$ 0.05$ & $\$ 0.06$ & $\$ 0.07$ & $\$ 0.08$ & $\$ 0.09$ & $\$ 0.11 \$$ & .12 \\
\hline lbs. & .06 & .06 & .06 & .08 & .11 & .14 & .17 & .21 & .2 \\
\hline lbs.. & .06 & .07 & .07 & .10 & .15 & .20 & .25 & .31 & \\
\hline $\mathrm{lbs}$ & .07 & .08 & .08 & .12 & .19 & .26 & .33 & .41 & .4 \\
\hline lbs.. & .07 & .09 & .09 & .14 & .23 & .32 & .41 & .51 & .60 \\
\hline lbs.. & .08 & .10 & .10 & .16 & .27 & .38 & .49 & .61 & .7 \\
\hline lbs & .08 & .11 & .11 & .1 & .31 & .44 & .57 & .71 & .8 \\
\hline lbs & .09 & .12 & .12 & .20 & .35 & .50 & .65 & .81 & .9 \\
\hline lbs & .09 & .13 & .13 & .22 & .39 & .56 & .73 & .91 & 1.0 \\
\hline & .10 & .14 & .14 & .24 & .43 & .62 & .81 & 1.01 & 1.2 \\
\hline lbs & .10 & .15 & .15 & .26 & .47 & .68 & .89 & 111 & 1.32 \\
\hline $1 b$ & 11 & .16 & .16 & .28 & .51 & .74 & .97 & 1.21 & 1.4 \\
\hline & .11 & .17 & .17 & .30 & .55 & .80 & 1.05 & 1.31 & 1.5 \\
\hline lbs & .12 & .18 & .18 & .32 & .59 & .86 & 1.13 & 1.41 & 1.6 \\
\hline $1 \mathrm{~b}$ & 2 & .19 & .19 & .3 & .63 & .92 & 1.21 & .51 & $1 . \varepsilon$ \\
\hline & .13 & .20 & .20 & .36 & .67 & .98 & 1.29 & 161 & 1.9 \\
\hline lbs & .13 & .21 & .21 & .38 & .71 & 1.04 & 1.37 & 1.71 & 2.0 \\
\hline & 4 & .22 & .22 & .40 & .75 & 1.10 & 1.45 & 1.81 & 2.1 \\
\hline & & .23 & .2 & .42 & .79 & 1.16 & 1.53 & 91 & 2.2 \\
\hline $1 \mathrm{~b}$ & 5 & .24 & .24 & .4 & .83 & 1.22 & 1.61 & .01 & 2.4 \\
\hline & & .25 & .25 & .46 & .87 & 1.28 & 1.69 & 2.11 & 2.5 \\
\hline $1 \mathrm{~b}$ & .16 & .26 & .26 & .48 & .91 & 1.34 & 1.77 & 2.21 & 261 \\
\hline & 6 & .27 & .27 & .50 & .95 & 1.40 & 1.85 & 31 & 2.7 \\
\hline & & .28 & .28 & .52 & .99 & 1.46 & 1.93 & 2.41 & 2.8 \\
\hline & .17 & .29 & .29 & .54 & 1.03 & 1.52 & 2.01 & 2.51 & 3.0 \\
\hline & 8 & .3 & & .5 & 1.07 & 1.58 & 9 & 61 & 3.1 \\
\hline & & .31 & & .5 & 1.11 & 1.64 & 2.17 & 2.71 & 3.2 \\
\hline & 9 & .32 & & .60 & 1.15 & 1.70 & 2.25 & 2.81 & 3.3 \\
\hline & & .3 & .3 & .6 & 1.19 & 1.76 & 2.33 & .91 & 4 \\
\hline & & .3 & .34 & .6 & 1.23 & 1.82 & 2.41 & 1 & 3. \\
\hline & & 35 & .35 & .66 & 1.27 & 1.88 & 2.49 & & 3.72 \\
\hline & 1 & .36 & .36 & .68 & 1.31 & 1.94 & 57 & 21 & 3.8 \\
\hline & 1 & .37 & .37 & .70 & 1.35 & 2.00 & 2.65 & 31 & 3.9 \\
\hline & & 381 & & .72 & 1.39 & 2.06 & 2.73 & 41 & 4.0 \\
\hline & & 9 & & .74 & 43 & 2.12 & 2.81 & 51 & 4.2 \\
\hline & & 40 & 0 & .76 & 7 & 2.18 & 2.89 & 1 & $4.3 \%$ \\
\hline & & & & & & 2.24 & 7 & 1 & 4 \\
\hline & 4 & .42 & .42 & .8 & & 2.30 & & 3.81 & 4.5 \\
\hline & 4 & 43 & 3 & .82 & 59 & 2.36 & 13 & & 46 \\
\hline & & & & .8 & 3 & 2.42 & & 1 & \\
\hline & 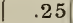 & .45 & .4 & .86 & 1.67 & 2.48 & 3. & 4.11 & 4.9 \\
\hline & 6 & .46 & .46 & .88 & 1 & 2.54 & 37 & 4.21 & 5.0 \\
\hline & & .47 & & .9 & 5 & 2.60 & 3 & 4 & \\
\hline & 7 & 4 & .4 & .92 & 9 & 2.66 & 3. & 4.41 & \\
\hline & & 49 & 9 & .94 & .83 & 2.72 & 3.61 & 4.51 & 5.4 \\
\hline & & & & .9 & 1.87 & 2.78 & 3. & 4.61 & 5 \\
\hline & & .5 & & .9 & 1 & 2.84 & 3.77 & 4.71 & 5.6 \\
\hline & & & & 1 & & 2.90 & 3.85 & 4.81 & \\
\hline & & & & 2 & 9 & 2.96 & 3.93 & 4.91 & 5.8 \\
\hline & & 5 & & 1.04 & 2.03 & 3.02 & 4.01 & 5.01 & 6.0 \\
\hline & & & & & & & & & \\
\hline & & & & & & & & & \\
\hline & & & & .10 & & & & & \\
\hline & & & & & Parc & & Is & to & fol \\
\hline & & 5 & & 4 & win & 11 & ints, & onside & $\lambda d$ \\
\hline & & 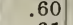 & .60 & 1.16 & & of & de 8 th & Zone. & \\
\hline & & & & 1.18 & lask & & $\mathrm{Cu}$ & & \\
\hline & & .6 & & 1.20 & Canas & & Gus & & \\
\hline & & .6 & & 122 & Canal & $1 \mathrm{Zo}_{0}$ & & 9 & [sls \\
\hline & & & & 1.24 & Mexi & & Phi & ilippin & \\
\hline $1 \mathrm{~b}$ & 35 & .65 & .65 & 1.26 & Repu & blic & of $\mathrm{Par}$ & nama & \\
\hline & 3 & .66 & .66 & 1.28 & Pago- & -Pago, & & tuila & lan \\
\hline & .36 & .6 & .6 & 1.30 & T & & $\mathrm{Ma}$ & nula & sland \\
\hline lb & 37 & .68 & .68 & 1.32 & & & & amoa) & \\
\hline & & .6 & .69 & 1.34 & ర. & & & Ag & \\
\hline & .38 & .70 & .70 & 1.36 & & Shan & ghai, & hina. & \\
\hline & 9 & .7 & $\because$ & 1.38 & & & & & \\
\hline & & .7 & & 1. & & & & & \\
\hline lbs.. & & .74 & \pm & 1.44 & & & & & \\
\hline
\end{tabular}

\section{NO WARRANTY!}

We Cannot Guarantee the Resuts of any seeds, plants or bulbs we send out-therefore:

N. L. Willet Seed Company give no warranty, ex press or implied, as to description, quality, produc tion, or any other matter of any seeds, bulbs or plants they send out, and they will not be in any way responsible for the crop. If the purchaser does not accept the goods on these terms, they are at once to be returned. This "No Warranty" clause is not only put thus prominently in our catalog, but is also printed on all of our bill heads, and is made a part of every sale of sceds in our house.

Germination Test-Never plant a crop of any kind of seed without first testing them yourself, for germination.

\section{SEEDS ARE SCARCE.}

The scarcity of seeds should make you get in your supplies at once of all garden and field seeds.

\section{CUSTOMERS PLEASE NOTICE}

If Goods Are Wanted by Parcel Post, Postage Must Be Added as Per Table Below Except for Those We Offe: to Deliver Free as Above.

The Parcel Post now includes Seeds, Plants, Bulbs and Roots.

Parcel Post Table-Consult same and remit extra for postage according to zone.

Insure Parcel Post Goods and include it extra in your remittance, as follows: $3 \mathrm{c}$ for ordor not over $\$ 5.00 ; 5 \mathrm{c}$ for order not over $\$ 25.00 ; 10 \mathrm{c}$ for order not over $\$ 50.00 ; 25 \mathrm{c}$ for order not over $\$ 100.00$.

We Pay War Tax-Special stamp of 1c where postage is $25 \mathrm{c}$ and $2 \mathrm{c}$ on a $26 \mathrm{c}$ to $50 \mathrm{c}$ postage, etc., and $1 \mathrm{c}$ for each $25 \mathrm{c}-$ We pay this.

Weight Limit Within 1st, 2nd and 3rd zone is 70 pounds, and within other zones 50 pounds.

Size Limit is 84 inches for combined length and girth.

4-oz. Package and less, takes postage rate of $1 \mathrm{c}$ per ounce; over $4 \mathrm{ozs}$. and up to $1 \mathrm{lb}$., takes first pound rate in Zone Table.

In Remitting Postage add it to the foot of the order.

Your Zone-Find your Zone (distance from Augusta) from your Postmaster or a Geography Map. 


\section{Calendar for Monthly Operations in the South What to Plant and When to Plant for Each Month in the Year}

\section{JANUARY}

For the Garden-Manure and prepare soil. Top dress asparagus beds with manure, also salt. Plant asparagus roots and cabbage plants; early crop of English Peas; otion sets, shallots, carrots, kale, radish, spinach, and turnips. Plant in hot beds or cold frames for later transplanting early cabbage, collards, lettuce, beets and cauliflower. Prune vines, fruit trees, hedges, etc. Spray fruit trees with Willet's Insecticides. Sow flower seed in hot beds for later transplanting.

For the Farm-Vetches oats and wheat can be sown, also re and bearded barley for grazing or for green erop. Top dress fall sown grain. Prepare land for spring crops. Send in orders for seed so as to have them on hand at proper time for sowing.

\section{FEBRUARY}

For the Garden-Plant asparagus roots and cabbage plants. Plant in hot beds, egg plant, pepper and tomatoes for later transplanting. Plant artichokes, Irish potatoes, English peas and onion sets. Later in the month early corn. Asparagus, beets, cabbage, carrots, collards, celery, mustard parsnip parsley radish salsify spinach and turnips can be sown. Finish pruning and transplanting rines and trees. Spray. Transplant strawberries. Hardy flower seed can be forwarded by sowing in hot beds, or in pots, seed can be forwarded by sowing in hot beds, or in pots,
or boxes in the house, for later transplanting. Sow Willet's evergreen lawn grass.

For the Farm-Bed sweet potatoes for slips. Sow Canada field peas, oats, rye and bearded barley. Towards end of month grasses and clovers can be put in. Sow beardless barley; cut in April makes an excellent crop for hay or grain, no danger in feeding, as it is free from beard. Comes off in time to plant cotton or corn. Sow dwarf Essex rape for early green grazing. Early corn can be planted.

\section{MARCH}

For the Garden-Active month for sowing all kinds hardy seed-the sooner the better. Set out asparagus roots. Plant Englísh peas. Transplant cauliflower, cabbage, lettuce from hot beds. Sow herbs. Plant asparagus, beets, early cabbage, corn, carrots, cauliflower, celery, collards, egg plant, Irish potatoes, kale, lettuce, mustard, okra, parsley, parsnips, pepper, radishes, spinach, spring turnips, tomatoes and salsify. Late in month plant a few turnips, tomatoes and salsify. Late in month plant a few snap beans. Tomato plants may be transplanted if protected. Prepare land for cantaloupes, cucumbers and
squash. Plant strawberries. Sow and transplant hardy squash. Plant strawberries. Sow and transpla
flower seed. Sow Willet's evergreen lawn grass.

For the Farm-Sow spring oats, Canada field peas, clover and grasses of all kinds, the earlier the better. Sow beardless barley, an excellent crop, comes off in time for cotton or corn. Plant artichokes, for hogs, also dwarf Essex rape. Put in first crop of Spanish peanuts. The month for plant ing corn. The majority of it should be put in by the 20 th Get land in condition for planting cotton.

\section{APRIL}

For the Garden-Replant any seeds necessary to secure good stand. Plant garden corn and snap beans every two or three weeks for succession. Transplant egg plant, pepper and tomatoes. Plant cantaloupes, squash and eucumbers; lawn grass; flower seed. Dahlias, gladiolus and canna bulbs can be set out. Plant sunflower seed in every vacant corner; beautifies; makes valuable seed for poultry in the fall.

For the Farm-The cotton planting month. Buy Willet's Cotton Planting Seed. Grasses and clovers can be planted early in the month. Plant corn, cotton, chufas, peanuts, rice, watermelons and all sorghums; millets and fodder corn can be planted during this month, likewise cow peas, velvet and soy beans. Plant sweet potato draws. Kaffir corn milo soy beans. Plant sweet potato for poultry in corn, milo maize and shallu make fine feed for poultry in
the fall. Plant Bermuda seeds or sets, bene for birds, feterita, sudan grass, dasheen, watermelons.

\section{MAY}

For the Garden-Transplant celery, Winter cabbage, to matoes, etc., can be set out, well watered and protected from the sun. Plant corn and snap beans, table peas and running beans. Late cabbage and cauliflower can be sown for transplanting in fall.

For the Farm-Plant sorghums, Millets, cow peas, corn, cotton, chufas, peanuts, rice and velvet beans and soy beans; also pumpkins. Get oats harvested and land in potato plants, sudan grass, kaffir and feterita, watermelons.
JUNE

For the Garden-Transplant winter cabbage, celery plants and tomatoes for late crop, water and protect from the sun; continue to plant corn and snap beans; running beans and table peas. Winter cabbage seed can be sown if protected and watered. Plant okra, salsify, New Zealand spinach an dsquash. Prepare ground for turnips.

Eor the Farm-Sow brown top millet and other millets sorghums, cow peas, soy beans, velvet beans, peanuts and chufas. Plant late corn and early cottons. Plant sweet potato cuttings, sudan grass, feterita and kaffir and beggar weed.

\section{JULY}

For the Garden-Gather and store onions, shallots and Irish potatoes. Plant rutabaga and turnips and beets. Replant cabbage and celery. Sow collards for transplanting in fall. Plant cucumbers for pickling.

For the Farm-Sow millets, cow peas and soy beans. Put in last crop Spanish peanuts. Plant Mexican June corn. Sow corn in drills for ensilage or fodder. Crimson and burr clover can be sown in the last plowing of corn and burr clover can be sown in the last plowing of corn Look Out Mountain potatoes.

\section{AUGUST}

For the Garden-Snap beans, lettuce, spinach, carrots, Romaine, salsify and turnips may be planted, also cucum bers for pickling. Set out late crop of tomato plants and earth up celery. Set out cabbage and collard plants for fall. Late in month English peas can be planted.

For the Farm-Crimson clover should be sown. Rye and bearded barley should be sown for fall and winter grazing. Rye can be planted as a cover crop and turned grazing. Rye can be planted as a cover crop and turned ander. and cut in October and November, followed by other grain
crops. Towards end of the month sow vetches and rape. crops. Towards end of the month sow vetches and rape
Grasses can be put in. Alfalfa and elovers can be planted. August 1st sow amber sorghum and sudan grass. Sow burr clover in cotton and corn middles.

\section{SEPTEMBER}

For the Garden-Carrots, kale, beets, chard, lettuce, Romaine, spinach, radishes, turnips, salsify, parsnip and parsley can be sown. Set out collards, winter cabbage. Put out onion sets for early crop. Strawberry beds should be prepared and plants set out. Sow Willet's evergreen lawn grass. Early flowering bulbs can be planted.

For the Farm-Sow beardless barley, cut in November. Cut in bloom makes excellent hay, and no beards can be fed to stock without danger. Comes off in time to be followed by other grain or clover or early crops. Sow crimson elover. Sow burr clover in Bermuda fields and in corn and cotton middles. Sow vetches, grasses and clover seed. Winter turf and grazing oats do well sowed clover seed. Winter turf and grazing oats do well sowed this month, as they get well rooted before the cold. Sow
barley and rye for winter grazing. Plant Dwarf Essex Rape and Willet's grazing mixture.

\section{OCTOBER}

For the Garden-Turnips ean be planted for winter use, but it is almost too late to bring roots to much perfection. Collards, kale, lettuce, mustard, spinach, chard, carrots, parsnips, cabbage plants, onion sets ean be sown Plant your strawberry beds. Plant hyacinth bulbs, tulips narcissus, jonquils, crocus, freezias and Chinese sacred lilies. Plant Willet's evergreen lawn grass.

For the Farm-All kinds of grasses and clovers can be sown. Clovers should be put in early in the month. Sow barley and oats, wheat, rye and vetches.

\section{NOVEMBER}

For the Garden-English peas may be planted this month also strawberry beds. Onion sets and cabbage plants can be planted. Begin to get ready to start spraying. Sow lawn grass and flower bulbs-see October.

For the Farm-Gather and bank sweet potatoes. Barley, oats, rye and wheat can be sown. Sow Canada field peas, vetches and clover and Willet's grazing mixture. Sow rye on all vacant land for fall grazing and cover crop to improve soil.

\section{DECEMBER}

For the Garden-Prepare hot beds and cold frames. Plant onion sets, cabbage and lettuce; beets can be sown in hot beds or cold frames for later transplanting. The winter growing of lettuce is very profitable. Prune trees and vines and spray for scale with Willet's spray materials. Plant asparagus roots.

For the Farm-Oats, wheat, vetches and clovers can be planted. Rye and barley for grazing and grain crops. Canada field peas can be sown, but must be planted deep. 


\section{SEFDS SOUTHERN STATES}

GARDEN SEEDS, 1919 PRICES :

YOTE! Of Help to Agriculture. It was our Mr. Willet who first exploited and practically gave to Southern Agriculture Fulghum Oats, Abruzzi Rye, Brown Top Millet, Georgia Hundred-Day Speckled Velvet Bean and Georgia Bush Velvet Bean. These matters are worth to the South today tens of millions of dollars.

All Garden Seeds, for many reasons, are h.gher than have ever been heretofore known. These prices are the very best that ca nbe given at the time of the issue of this catalog. Owing to the violent fluctuation in the market and great scarcity of certain types, these catalog prices are subject to change without notice. We advise all Garden Seed buyers to get in their orders at once, and very early, as many types of Garden Seeds in the latter part of the season, will not be available at any price.

\section{ASPARAGUS SEFD}

\section{Georgia Grown.}

Note-Largest dealers in Asparagus Seed and Roots. United States seed trade supplied.

Culture - Plant seed

by hand, March and

April, in $21 \frac{2}{\mathrm{ft}}$. rows, 2 deep; cultivate; use nitrogenous fertilizer, and salt; and in 12 months salt; and in 12 months set out plants-only
from best plants. One ounce of seed produces about 300 plants (roots) 16 pounds for one acre produce about 100,000 roots. Market Asparagus March to May 15 th. GIANT FRENCH ARGENTEUIL A S P A R AGU S-Of great reputation in France. We got our seed originally from France, and have care. fully grown it here in large amounts. A firstclass variety with beau. tiful smooth spears. Of large size and known everywhere over the

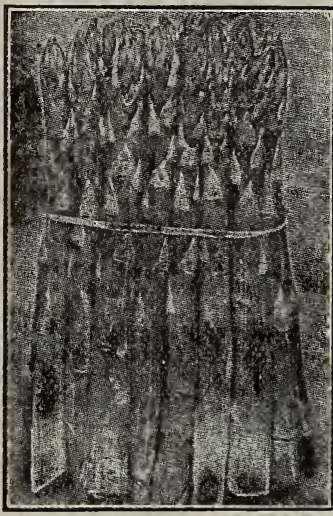

Giant Argenteuil Asparagus. world as a fancy high-priced asparagus, used by French canners. See prices below.

PALMETTO ASPARAGUS-Popular and grown extensively for a generation around Charleston. Possibly more Palmetto is grown than any other asparagus. See prices below.

BEN TILLMAN ASPARAGUS-Introduced by Senator Tillman. Now largely grown about Augusta. As early as the earliest, extremely vigorous, grows larger and more uniform stalks and spears than any other variety. Has a less percentage of culls. Spears are nice and smooth look well in bunches. The largest growers in America, who live near Augusta, pronounce this the best of all known asparagus. We have individual growers here who plant 300 acres of it. See prices below.

PRICES for all of the above kinds-Pkt. $5 \mathrm{c} ; 1 \mathrm{oz} .10 \mathrm{c}$; $1.4 \mathrm{lb} .20 \mathrm{c} ; 1 \mathrm{lb} .40 \mathrm{c} ; 5 \mathrm{lbs}, 30 \mathrm{c} ; 10 \mathrm{lbs}$. $25 \mathrm{c}$.

WASHINGTON RUST-RESISTANT ASPARAGUS-New. Introduced and developed by the Government. It has the largest spears, is more productive, is earlier and more uniform than other known asparagus, and is far more disease-resistant. It is the finest known asparagus! This grass created a great sensation in the Washington market

Price: 1 oz. $40 \mathrm{c} ; 4$ ozs. $\$ 1.25 ; 1$ lb. $\$ 4.00$.

\section{ASPARAGUS ROOTS}

Culture for Garden-Where soil is light and rich, open up furrows 3 inches deep, and 4 to 6 feet apart. Place roots in the bottom of furrow, 12 to 18 inches apart; cover with 2 or 3 inches of soil. As shoots appear, fill in get your beds too rich or use too much manure for the crop. One hundred root sets a bed $10 \times 40$ feet.

Culture for the Farm-Lay rows 6 feet apart. Scrape out soil in water furrow so that level of water furrow will be 7 or 8 inches below the ground. Plant crowns with eye up, straight in the row, and 27 or 28 inches apart, cover with 2 or 3 inches of soil. For first two years, cultivate and gradually throw soil over into water furrow until the water furrow is itself a raised bed. Soil needs to be rich - guano or stable manure. Plant roots from November to March; market March to May 15th. Roots ean not be dug and planted until after frost kills the tops.

NOTE! Augusta is the center of the largest Asparagus industry in United States. Within 20 miles of the city there is one single unbroken field of 400 acres, being not only the largest single field in the United States, but also in the world.

PRICES-We supply any variety in catalog from November to April. Will bear transportation to any part of United States. 1,000 roots weigh about 100 lbs. 4,000 to 5,000 per acre. Duration of beds from 12 to 15

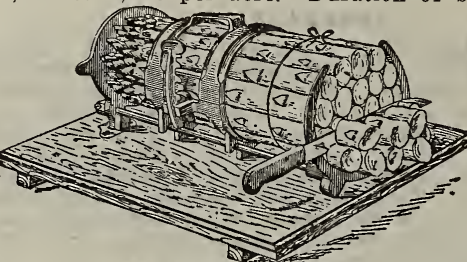

Asparagus Bunchers. years. 100 roots, $\$ 1.00 ; 500$ roots, $\$ 2.50 ; 1,000$ roots, $\$ 4.25 ; 5,000$ roots at $\$ 3.75$ per $M$. Write for prices on large amounts. "ASPARAGUS", Ge t Farmers' Bulletin 829 on Asparagus.

ASPARAGUS BUNCHERS-

No. 2,7 to 9 -inch Bunchers

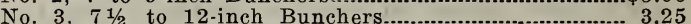
ASPARAGUS KNIVES-

Latest Improved, each.............................................\$0.50 NATURAL-COLOR PAPER RAFFIA-(Crimped.) A substitute for raffia (raffia can not be bought). 960 yards in one pound Price: $1 \mathrm{lb}, 60 \mathrm{c} ; 5 \mathrm{lbs}$ at $55 \mathrm{c} ; 25 \mathrm{lbs}$. at $50 \mathrm{c}$ per $\mathrm{lb}$. Postage extra, f. o. b. Pennsylvania.

\section{FRENCH ARTICHOKE}

GRFEN GIOBF-Grown for the undeveloped heads. Cooked like asparagus it makes a most tender and excellent vegetable; eat with butter sauce or French dressing. Once planted it lasts for several years. Sow in May and thin out to 4 inches, and following spring transplant to rows 5 feet apart each way. Pkt. $10 \mathrm{c} ; 1$ oz. $\$ 1.50 ; 4$ ozs. $\$ 4.00$.

JERUSALEM ARTICHOKE-Grown from roots or tubers. Sometimes used as a vegetable and for pickling. Plant and cultivate like potatoes. Fuller information is given under head of "Farm Seeds."

Prices-Quart 20c; peck $75 \mathrm{c}$; bushel $\$ 2.50 ; 5$-bushel lots and over, $\$ 2.25$ bushel.

\section{Garden Beans BUSH or SNAP BEANS}

USE MULFORD CULTURES-Garden Size, 25c and 1.4 acre, $50 \mathrm{c}$.

Culture-For earliest crop, plant first of March. For succession, plant every two weeks throughout summer until September Late Snaps make satisfactory crop; should be more generally grown. For field culture, plant in rows $2 \frac{1}{2}$ to 3 feet apart and 3 inches between the beans, cov ering about 2 inches. If cultivated by hand in small gardens, rows may be 2 feet apart. Up to time of blooming cultivate often, but never when the vines are wet, as pods and leaves would become discolored and rust. Ready in sixty days. Market, May 15 th to October 15th. Plant beans in Florida from January 15 th to April; also August and September. One quart plants 100 feet of drill; $11 / 2$ and September.

BEANS BY MAIL-For all beans, when sent by mail, add for postage; half pint $5 \mathrm{c}$; pint $10 \mathrm{c}$; quart $15 \mathrm{c}$

HOPKINS' IMPROVED VALFNTINE-Strain of Red Valentine perfected through many years of careful atten tion. Hardy, vigorous, upright in growth, holding pods well up from the ground. Early and remarkably uniform in height as wel las ripening. One of the finest beans grown for market gardeners, as a large proportion of crop can be secured at one picking. As early as any strain of Red Valentines, and fully as uniform of habit and ripening, with an almost entire absence of flat pods. Pods 5 to 6 inches long, round, thick and meaty, tender and of fine flavor. Seed similar in appearance to Extra Early Red Valentine, but of a darker shade of red, inclined toward square ends. Packet $5 \mathrm{c}$ and $10 \mathrm{c}$; $1 / 2$ pint $25 \mathrm{c}$; pint $45 \mathrm{c}$; quart $80 \mathrm{c} ; 1 / 2$ peck $\$ 2.70$; peck $\$ 4.75$; bushel $\$ 15.00$. 


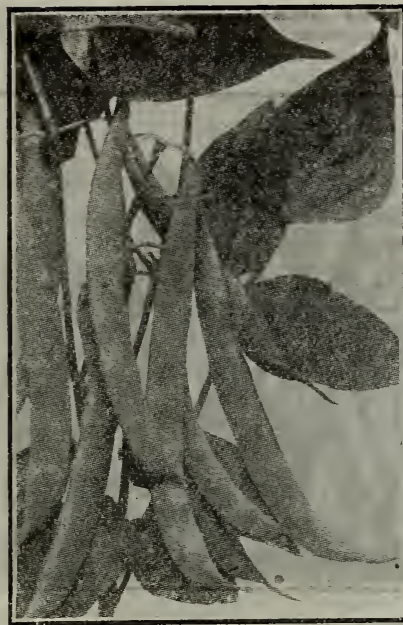

Valentine Beans.

B I A C K VALENTINE-Excellent bean for market gardeners, especially in earliness in abundance of pods and uniform ripening. Extensively used in the South as the pods retain their color and freshness. Fairly good flavor and handsome in appearance. Vines vig. orous and very hardy, orous and very hardy, holding pods well up 5 to $5 \frac{1}{2}$ inches long, round, thick, meaty, tender and stringless. seed mediu m size, black. Becoming more popular each season. Hardy, and will stand Hardy, and will stand more frost and cold winds, consequently can be planted earlier with less risk. Packet $5 \mathrm{c}$ and $10 \mathrm{c} ; 1 / 2$ pint $25 \mathrm{c}$; pint $45 \mathrm{c}$; quart $80 \mathrm{c} ; 1 / 2$ peck $\$ 2.70$ peck $\$ 4.75 ;$ bushel $\$ 15.00$.

GIANT STRINGLESS GREEN POD-A very early $\nabla$ riety; 1 o $n$ traight, roun $\begin{array}{lllll}\text { and } & e & h & y \\ \text { pods, } & r & e & e\end{array}$ from strings good bearer healthy grower. The dry b e a $n$ s are $\mathbf{v}$ a 1 , of $\mathrm{ch}$ he brown color and of a fleshy appeara $n$ c e. Packet, $5 \mathrm{c}$ and $10 \mathrm{c} ; 1 / 2$ pint, $30 \mathrm{c}$; pint, $50 \mathrm{c}$; quart, $85 \mathrm{c} ; 1 / 2$ peck, $\$ 3.00$ peck, $\$ 5.25$

bu., $\$ 16.00$. BURPEE'S STRINGLESS GREEN POD -Marked by extreme earliness and productiven e s s. saddlebac $\mathrm{k}$ s. Hardier a $n$ d will s $\mathrm{t}$ a $\mathrm{n}$ d will s $t$ a $n$

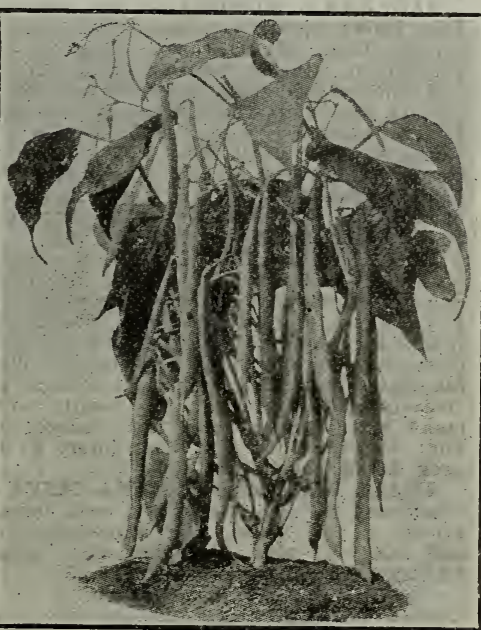

Giant Stringless Green Pod. than many other early kinds; entirely stringless. Makes a round podded snap, tender, and of excellent quality. Packet $5 \mathrm{c}$ and $10 \mathrm{c}$; $1 / 2$ pint $30 \mathrm{c}$; pint $50 \mathrm{c}$; quart $85 \mathrm{c}$; $1 / 2$ peck $\$ 3.00 ;$ peck $\$ 5.25 ;$ bushel $\$ 16.00$.

IMPROVED GOLDEN WAX-GRENELL'S-Pods large long, brittle and entirely stringless, and of a beautiful rich golden, wax color. As a snap bean it excels every

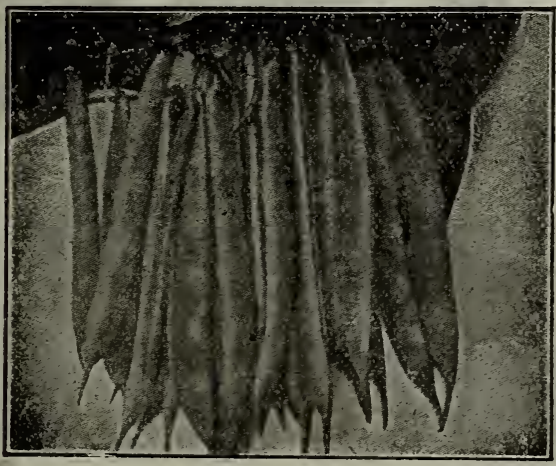

Bountiful Beans. other variety in tenderness and rich buttery flavor, while as a shell bean for winter use it has few or no superiors. It is very prolific, of dwarf, compact growth. Pods $3 \frac{1}{2}$ inches long, straight and flat; light cream wax color. Seed white splashed with purplish black. Packet $5 \mathrm{c}$ and $10 \mathrm{c}$ $1 / 2$ pint $30 \mathrm{c}$; pint $5 \mathrm{c} \mathrm{c}$; quart $95 \mathrm{c} ; 1 / 2$ peck $\$ 3.25 ;$ peck $\$ 5.50 ;$ bushel $\$ 16.50$.

BOUNTIFUI-Should have an extensive sale, as it is one of the best green podded beans on the market, especially for market gardeners; as hardy and productive as Six Weeks, with stringless pods of excellent quality. Pods 5 to 6 inch s long broad, flat, thick and meaty, ver stringless. Seed medium size, rellow. The stringless ten der flat green pods c me very early. Produce heavily and keep on bearing a great while. Practically a stringless early yellow six weeks. Packet $5 \mathrm{c}$ and $10 \mathrm{c} ; 1 / 2$ pint $25 \mathrm{c}$; pint $45 \mathrm{c}$; quart $80 \mathrm{c} ; 1 / 2$ peck $\$ 2.70$; peck $\$ 4.75$; bushe $\$ 15.00$.

CURRIE'S RUST-PROOF WAX-One of the earliest of the wax sort: vines strong robust and upright, holding the pods well off the ground. Pods are long, flat and tender, of a beautiful golden color, and of finest quality. Pods $4 \frac{1}{2}$ tot 5 inches long. Flat, tender, early to ripen. Seed larger than Black Wax, and are purplish black in $95 \mathrm{c} ; 1 / 2$ peck $\$ 3.25$; peck $\$ 5.50$; bushel $\$ 16.50$

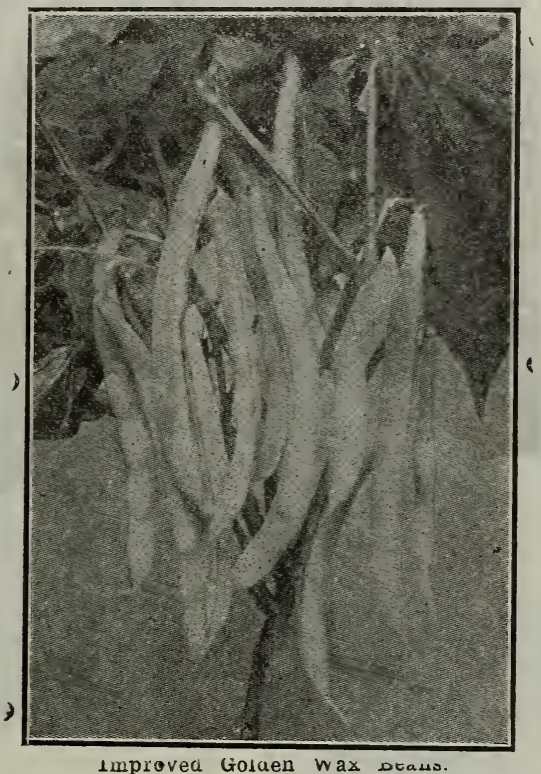

FARIY YELLOW SIX WEEKS-Hardy and very early reen pod; resembles Mohawk, save in color. Upright hery heavy cropper, uniform in ripening. $51 / 2$ inches long, nearly straight, flat, and of good quality. Seed long, yellow. $1 / 2$ peck $\$ 2.70 ;$ peck $\$ 4.75$; bushel $\$ 15.00$.

WARDWELL'S KIDNEY WAX-Early as the Golden Wax; pods very long, tender, stringless and of fine light colden color. Grows taller than Goluen Wax. The truckers' favorite in yellow wax beans. Packet $5 \mathrm{c}$ and $10 \mathrm{c}$. $1 / 2$ pint $35 \mathrm{c}$; pint $60 \mathrm{c}$; quart $\$ 1.00$; $1 / 2$ peck $\$ 3.75$; peck $\$ 6.25$; bushel $\$ 17.50$.

PIX WEEKS-Our hardiest bean. Perhaps the oldest of the green podded sorts, very hardy, resisting even a slight degree of frost. Foliage very coarse and straggling dark green, early and very prolific. Pods 4 to $4 \frac{1 / 2}{2}$ inches long, straight, flat, broad and of medium quality. Seed large, of purplish shade splashed with lighter color. Packet $5 \mathrm{c}$ and $10 \mathrm{c} ; 1 / 2$ pint $25 \mathrm{c}$; pint $45 \mathrm{c}$; quart $80 \mathrm{c} ; 1 / 2$ peck $\$ 2.70$; peck $\$ 4.75$; bushel $\$ 15.00$.

DWARF GERMAN BLACK WAX-Of prolific type. An old variety. Tender wax pods. Strong healthy foliage, pods, $4 \frac{1 / 2}{2}$ to 5 inches long; thick, curred, round, meaty and tender. Creamy white, excellent quality. Seed oblong, glossy black. Packet $5 \mathrm{c}$ and $10 \mathrm{c} ; 1 / 2$ pint $35 \mathrm{c}$; pint $55 \mathrm{c}$; quart $95 \mathrm{c}$ : $1 / 2$ peck $\$ 3.25$; peck $\$ 5.60$; bushel $\$ 17.00$.

EXTRA EARIY REFUGE, or 1000 to $1-A$ sevenweek plant, medium to late. Variation from the old Refugee or Thousand to One, more dwarf and compact in ugee or Thousand to fix growth, and earler, light green, nearly straight, solid, Weeks. Pods round, light green, nearly straight, solid, tender of good quality either for canning or pickling.
Seed resembles that of Refugee Wax. Packet 5c and $10 \mathrm{c}$; $1 / 2$ pint $25 \mathrm{c}$; pint $45 \mathrm{c}$; quart $80 \mathrm{c} ; 1 / 2$ peck $\$ 2.70 ;$ peck $\$ 4.75$; bushel $\$ 15.00$ 


\section{POLE, or CORNFIELD SNAP}

USE MULFORD CULTURES for legumes. 1-4 acre, 50c; garden size, $25 \mathrm{c}$.

Cuture-Pole beans are more sensitive to cold and wet than bush beans, and should not be planted before April Set poles 8 feet long firmly in the ground, 4 feet apart each way, and put five or six beans, eye downward, in each hill. One pint will plant about 100 hills, one or two pecks plant an acre. Also largely planted in corn. Some pant two Russian sunflower seeds to each hill for beans to train on; pick off lower sunflower leaves to give sunlight. Ready for market, 70 to 80 days.

SOUTHERN WHITE CREASEBACK, Or FAT HORSELarge, long, round pods, growing in clusters of from six to twelve: silver green; the best quality of snaps. A good corn-hill bean for late planting for fall market. Packet $5 \mathrm{c}$ and $10 \mathrm{c} ; 1 / 2$ pint $40 \mathrm{c}$; pint $60 \mathrm{c}$; quart $\$ 1.15 ; 1 / 2$ peck $\$ 4.00$; peck $\$ 6.40$; bushel $\$ 18.25$.

RED SPECKLE CUT SHORT or CORN-HILL-An old varicty; popular for planting among corn; gives fair crop without use of poles; vines medium, not twining tightly pods short, cylindrical and tender; bean nearly oblong, cut reddish-brown dots; makes until frost. Packet 5c and $10 \mathrm{c} ; 1 / 2$ pint $45 \mathrm{c}$; pint $70 \mathrm{c}$; quart $\$ 1.20 ; 1 / 2$ peck $\$ 4.35$; peck $\$ 6.75$; bushel $\$ 18.75$.

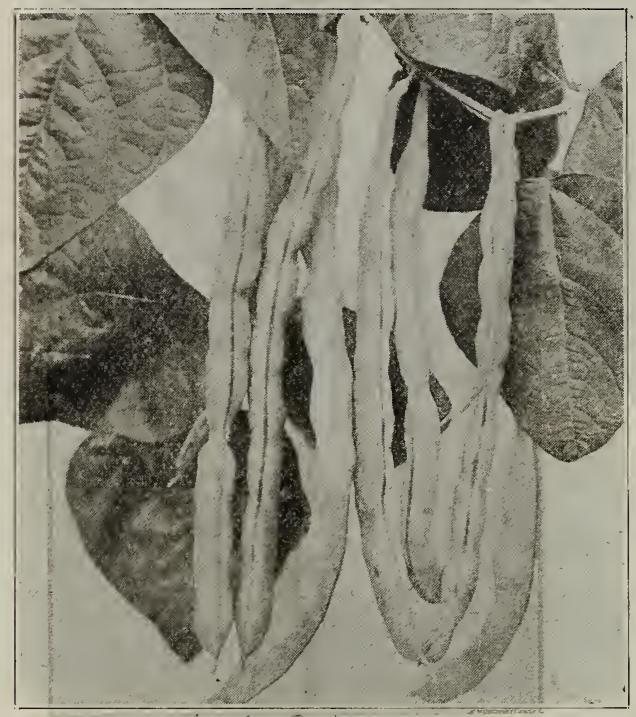

Kentucky Wonöer.

OLD HOMESTEAD, OR IMPROVED KENTUCKY woND - Pods seven to nine inches in length, saddlebacked and solidly meaty, and of finest quality. String less when young. Be sure to gather pods as they mature, and vines will continue bearing to end of season. Enormously productive. Pods in clusters. Bright green color. Packet $5 \mathrm{c}$ and $10 \mathrm{c}$; $1 / 2$ pint $35 \mathrm{c}$; pint $60 \mathrm{c}$; quart $\$ 1.05$; $1 / 2$ peck $\$ 3.75$; peck $\$ 6.25$; bushel $\$ 17.50$.

SOUTHERN PROLIFIC-A Southern bean. Stands Southern heat. Continues to bear until frost. Pods 7 inches long and flat; seed dark yellow. Standard in this latitude. Favorite way to plant in the South is in damp land among corn, and let the vines grow up the cornstalks. Packet 5c and $10 \mathrm{c} ; 1 / 2$ pint $35 \mathrm{c}$; pint $60 \mathrm{c}$; quart $\$ 1.05 ; 1 / 2$ peck $\$ 3.75$; peck $\$ 6.25$; bushel $\$ 17.50$.

\section{LIMA BEANS}

USE MULFORD CULTURES for Legumes. 1-4-acre 50c; garden size, $25 \mathrm{c}$

Culture-Lima Beans should not be planted before the weather gets warm in April. Of the large seeded sorts, one quart plants 100 hills; of the smaller sorts, one quart plants 200 hills. Poles 3 to 10 feet in length should be firmly set in center of hills before seed are planted. Bush Limas should be planted 3 feet apart, dropping two or three beans 15 inches apart in the rows. Cover about $1 \frac{1 / 2}{2}$ inches deep. About $1 \frac{1 / 2}{2}$ to 2 pecks plants an acre.

BURPEE'S LARGE BUSH IIMA-A bush form of the large pole Lima. Beans are large and flat, like those of that variety. Productive; its dwarf character is well esquart $\$ 1.20 ; 1 / 2$ peck $\$ 4.15 ;$ peck $\$ 7.25 ;$ bushel $\$ 19.75$.
HENDERSON'S DWARF SMALL LIMA-By successive plantings can get two or three crops; yield per acre, 100 bushels; plant same time as Bush Snap. Bush is dwarf

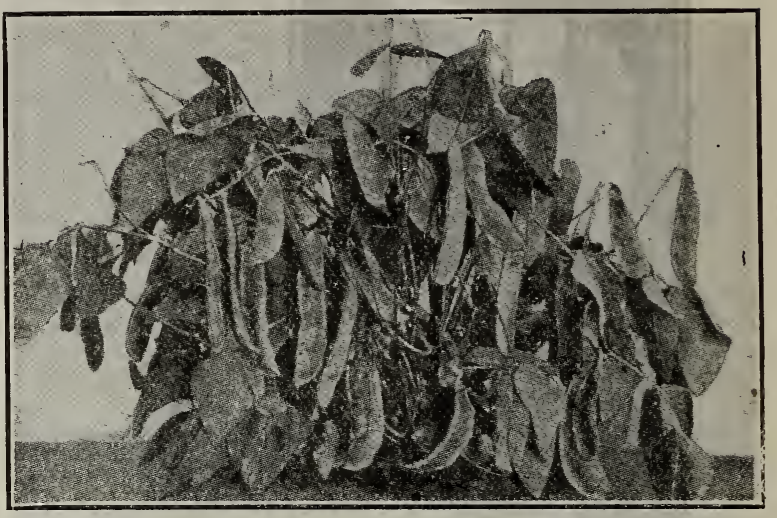

Henderson's Bush Lima Beans.

and beans are small Limas. Packet $5 \mathrm{c}$ and $10 \mathrm{c} ; 1 / 2$ pint $35 \mathrm{c}$; pirt $60 \mathrm{c}$; quart $\$ 1.05 ; 1 / 2$ peck $\$ 3.75 ;$ peck $\$ 6.25$; bushel $\$ 17.50$.

JACKSON'S WONDER-A flat brown bean, mottled, with deep brown spots; size somewhat larger than Sieva. Most prolific Bush Lima grown. Originated in Georgia; iully adapted to all the South. Flourishes in dryest weather and almost drought-proof. Flavor rich and delicious. perfect bush butterbean, growing 18 inches to 2 feet high. Begins blooming early, and if kept closely picked conBegins blooming early, and if kept closely picked con-
tinues to bear until frost kills plants. Good for summer tinues to bear until frost kills plants. Good for summer
use or as a winter shelled bean. One of the most valuable use or as a winter shelled bean. One of the most valuable introductions for Southern home gardens ever made. Packet $\$ 3.75$; peck $\$ 6.25$; bushel $\$ 17.50$.

FLORIDA BUTTER IIMA-A sure bearing Pole Lima bean. You can't beat it for bearing anywhere in the South. It grows and bears profusely all through the season. Makes fine on poor land; begins early and stays late. furnishing plenty of delicious butterbeans for fall use and furnishing plenty of delicious butterbeans for fall use and
then some for dry beans in winter. We have known Florthen some for dry beans in winter. We have known Florida Butter for 20 years. It's a bean you can depend on. Heaviest of bearers and the quality will please you. Will make where other sorts fail completely. Packet $5 \mathrm{c}$ an 10c; $1 / 2$ pint $35 \mathrm{c}$; pint $60 \mathrm{c}$; quart $\$ 1.05 ; 1 / 2$ peck $\$ 3.75$

SMALL LIMA, or CAROLINA SIEVA (Pole)-Similar in every way to large seeds, and pods being smaller. Largely grown in the South, and immensely popular. Packet $5 \mathrm{c}$ and $10 \mathrm{c} ; 1 / 2$ pint $40 \mathrm{c}$; pint $65 \mathrm{c}$; quart $\$ 1.15 ; 1 / 2$ peck $\$ 4.00$; peck $\$ 6.40$; bushel $\$ 18.25$.

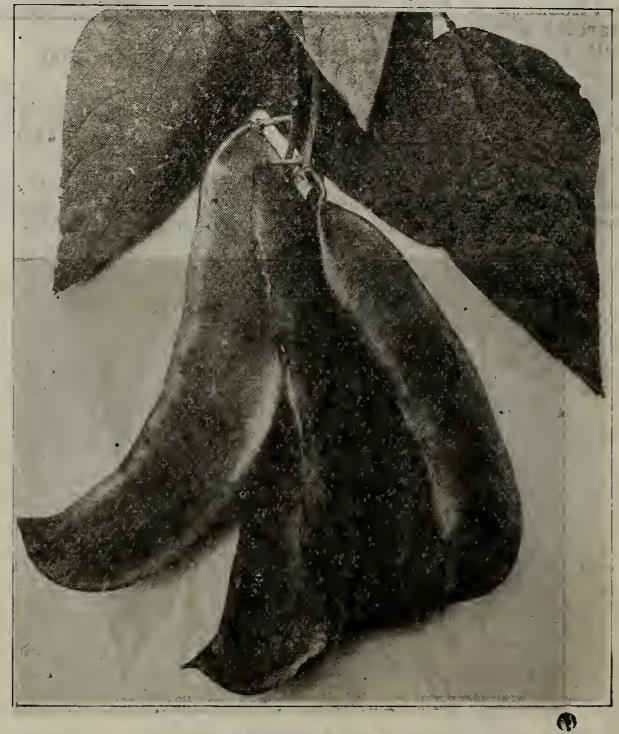

Small Lima, or Carolina Sieva. 
IARGE WHITE IIMA (Pole) - Either green or drv, this the standard table regetable and the best shell bean known. Give it rich ground and plenty of room. Packet $5 \mathrm{c}$ and $10 \mathrm{c} ; 1 / 2$ pint $40 \mathrm{c}$; pint $65 \mathrm{c}$; quart $\$ 1.15 ; 1 / 2$ peck $\$ 4.00$; peck $\$ 6.25$; bushel $\$ 18.25$.

\section{BEETS}

Culture- Sow as soon as ground can be worked. Ready in 75 days. Thrive best in light, loose, deeply worked oil, well manured. Winter beets and mangels should be sown in April or May, or as late as June. Seed should be soaked before sowing. For field culture, sow in drills 2 to $2 \frac{1}{2}$ feet apart, and cover 1 inch; thin out to 4 inches. One ounce sows 50 feet of drill; 6 to 8 pounds one acre. For small garden the drills need not be more than 15 inches apart. Garden beets can also be sown from June to October, for use during the fall and early w The young tops are superior to turnips and spinach for

For Succession-Beets, followed by snapbeans or okra in June, and by winter radishes, turnips, onions or spinach in October. Plant beets in Florida in December and May.

EARLY ECLIPSE-The handsomest of the very early beets. Globe-shaped, fine dark red color, rapid grower, small tops, purplish green foliage and red reins. Packet $5 \mathrm{c}$; ounce $15 \mathrm{c} ; 4$ ounces $40 \mathrm{c}$; pound $\$ 1.00$.

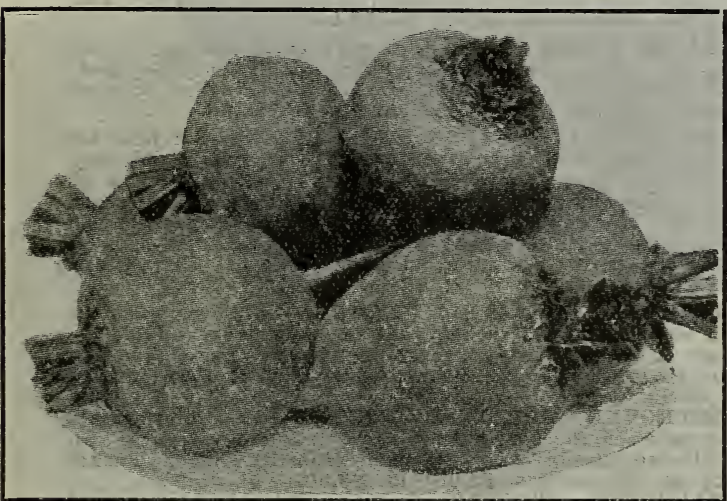

Early Eclipse Beets.

IMPROVED EARLY DARK BLOOD TURNIP-Trifle later than Eclipse; flesh deep blood red; tender and n̂ne flarored. The most generally used family beet. Packet $5 \mathrm{c}$; ounce $15 \mathrm{c} ; 4$ ounces $40 \mathrm{c}$; pound $\$ 1.00$

DARK RED EGYPTIAN-Highly prized by market gardeners everywhere; size about 3 inches. Slightly flattened; skin dark red; flesh fine, compact texture, tender, of superior flavor. Packet $5 \mathrm{c} ; 1$ ounce $15 \mathrm{c} ; 1-4$ pound of superior flavor.

EXTRA EARLY, or BASSANO-As early as Eclipse; flesh pink, with white streaks; very juicy. Packet 5c; ounce $15 \mathrm{c} ; 4$ ounces $40 \mathrm{c}$; pound $\$ 1.00$.

IMPROVED LONG SMOOTH BLOOD RED-Medium late; often used for late summer planting and winter use. Packet $5 \mathrm{c}$; ounce $15 \mathrm{c} ; 4$ ounces $40 \mathrm{c}$; pound $\$ 1.00$

HALF LONG BLOOD RED-Similar to Long Blood, but differ's in size, being half long. Packet $5 \mathrm{c}$; ounce $15 \mathrm{c} ; 4$ ounces $40 \mathrm{c}$; pound $\$ 1.00$.

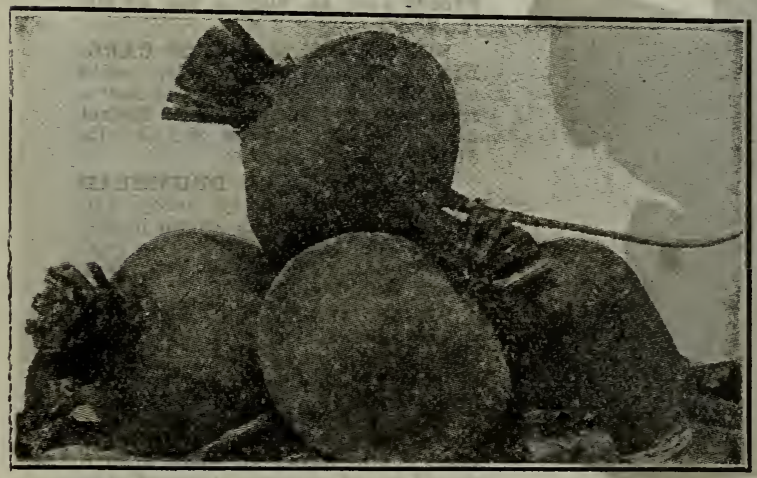

Improved Blood Turnip Beet.
SILESIAN SUGAR WHITE-A sweet white beet preferred by some: Packet 5c; ounce 15c; 4 ounces $40 \mathrm{c}$; pound $\$ 1.00$

SWISS CHARD, or SPINACH BEET-Sow spring and fall in drills 12 to 18 inches apart. Leaves can be cropped, six times during season. Plant grows $2 \frac{1 / 2}{2}$ feet high. In cutting keep the outside (only) leaves cut and the plant will continue to put out leaves as a continuous bearer, al most all the year. Poultry fond of it; take a dozen or two of the leaves; tie them in a bunch and hang them up so

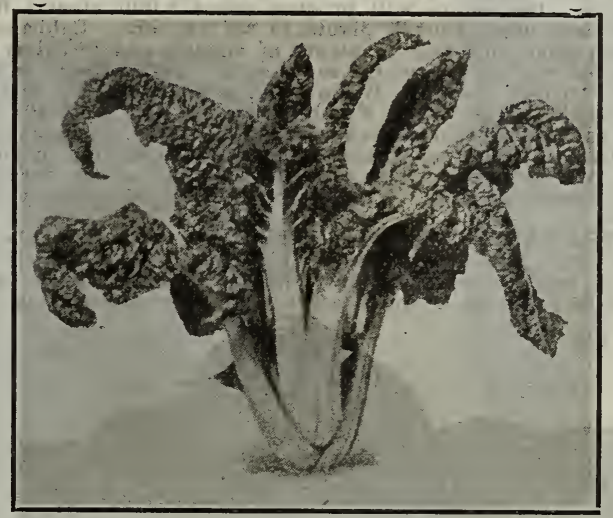

Swiss Chard.

that the chickens can pick at tliem easily. The birds are extremely fond of this kind of greens. Not grown for its roots, but as a salad; desirable because it combines two vegetables in one, the young leaves to use as greens, and later the broad, flat, beautiful waxlike leaf stems are cooked and used either as a salad or like asparagus; also makes desirable pickles. A very attractive plant, and should be grown in every garden. The new leaves are always put out from the center of the plant. The leaves are large, with heavy stems very tender and brittle. Plant February 1st to April 15th; July to September. Packet $5 \mathrm{c}$; ounce $20 \mathrm{c} ; 4$ ounces $50 \mathrm{c}$; pound $\$ 1.50$.

\section{BEETS FOR STOCK. \\ OR MANGEL WURZEL.}

NORBITAN GIANT-We have tried to get in this the largest stock beet that grows. A long red variety of great size. Flesh solid: 4 ounces $25 \mathrm{c}$; pound $50 \mathrm{c}$.

BRUSSELS SPROUTS Closely akin to the cab bage and collard. Treated in the South just like collards. It produces a peculiar erect stock, about 2 feet high and bears numerous little sprouts shaped like a head of cabbage. These set thickly on the close-jointed stalk, and develop to their entire height all at the same time.

PERFECTION - The $\mathrm{Va}$ riety for the South. Grows 2 feet high and produces from the stem numerous little sprouts, 1 or 2 inches in diameter, resembling cab bage. The sprouts are used as greens and become very aren and become ed by frost. Sow in May, or for succession through or for succession through the year, and cultivate same as cabbage. One ounce makes 1,000 or more plants. Packet $5 \mathrm{c}$; 1 ounce $-45 \mathrm{c}$

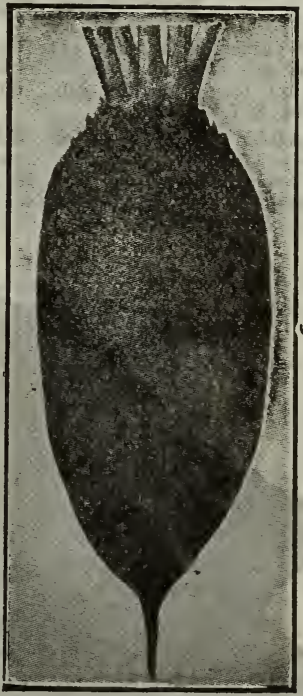

Norbitan Giant Beet.

\section{CABBAGFS}

Our Cabbage Seed.-We pay more for our cabbage seed than do the greater portion of the seed trade of America. Our Cabbages are grown for us by the best-known and most reliable cabbage sced growers in the United States. No better cabbage seed than those we offer.

Culture-For a succession sow the early varieties in cold frames in January, February, or early March; later, sow the early varieties out of doors, in March or April; for 
winter cabbage sow in April, May or June, transplanting in July or August to head up during the late fall and winter. Fall sowings, to make plants for setting out in the fall or early spring, should be made after September 20 th; if sown earlier they will likely shoot to seed, especially in if sown earlier they will likely shoot to seed, especially in the flat-headed kinds. $1 / 2$ tot 3 feet apart; late varieties, beinches apart in rows $21 / 2$ tot 3 feet apart; late varieties, be-
ing larger, should be set out 2 to 3 feet in row; rows 30 inches apart; 7,000 to 8,000 plants per acre; ready for use in 100 to 160 days. For drilling, 4 ounces seed 100foot row. One ounce will produce about 2,000 plants; 6 ounces will make enough plants to set an acre. Cabbage requires good, rich soil, or plenty of manure and fertilizer, and to be worked frequently and deeply. For cabbage and collard "Green Cabbage Worm" spray young plants with collard "Green Cabbage Worm spray young plants with Plant cabbage in Florida January and February, September and October. Seed sown, are ready for transplanting in 30 days. We make a specialty of selling cabbage seed to large cabbage plant growers. Cabbage seed are higher than ever known.

EXTRA EARLY JERSEY WAKEFIELD-Most desirable extra early; supposed to be the earliest of all cabbages; pointed head; excellent table qualities; sure heading; a satisfactory variety. Can plant close; not so large as some

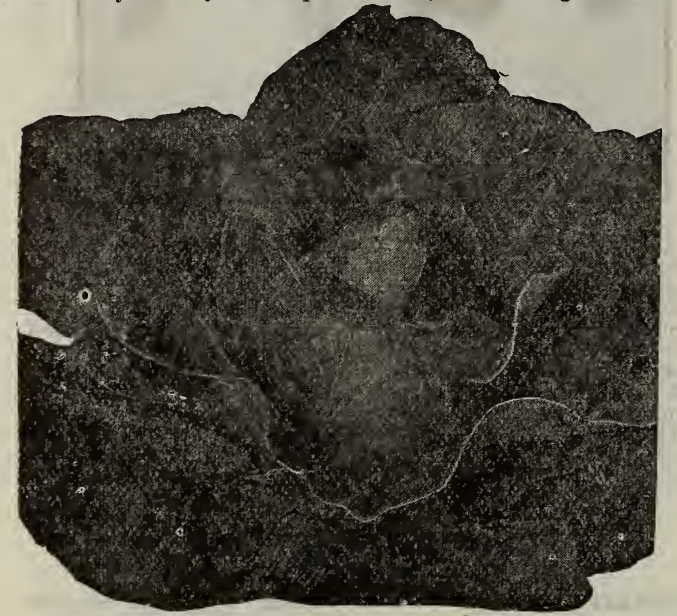

Early Jersey Wakefield Cabbage.

later varieties, but for extra earliness the best of all. The heads are of good size, cone form, broad at the base, with twisted top. Packet 10c; ounce $\$ 1.00 ; 4$ ounces $\$ 3.00$; pound $\$ 10.00$.

EARLY CHARLESTON WAKEFTELD-Early and well known favorite; heads are conical shaped; possibly the principal variety that is grown by truckers for early shipments, and by gardeners in general. Quantities of this

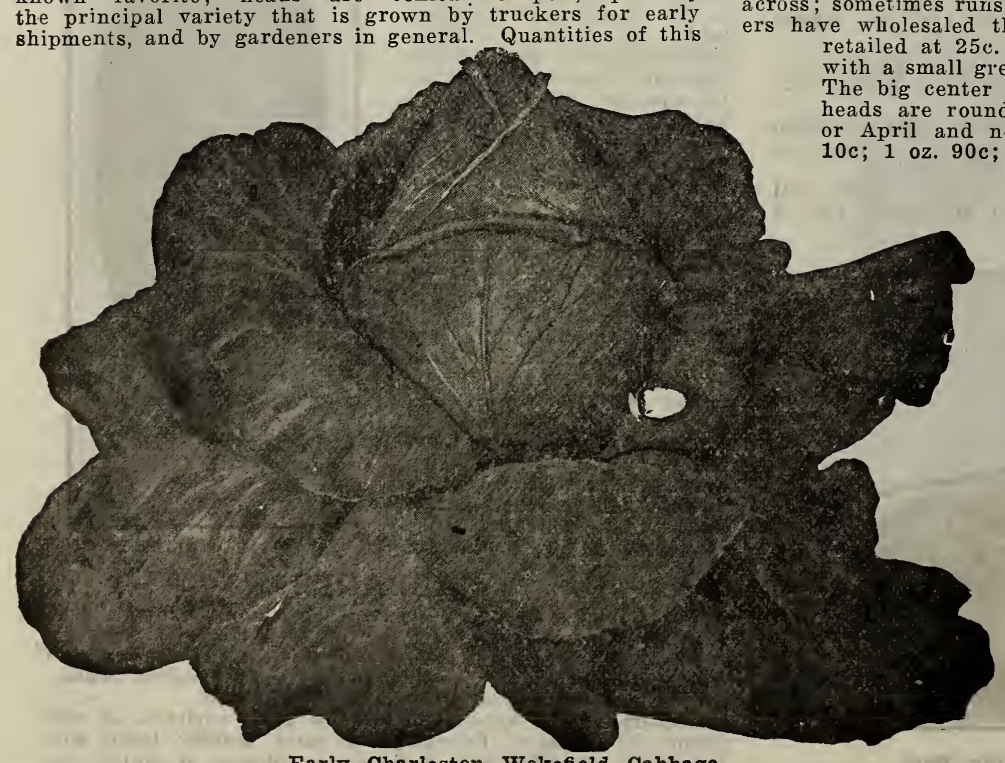

Early Charleston Wakefield Cabbage. $\$ 2.00 ; 1 \mathrm{~b} . \$ 6.00$. cabbage now off Charleston in 22 pounds weight, all solid heads; 10 days later in heading than Early Jersey Wakefield; one-third larger in size. It is the best and most profitable early variety to grow for either market or private gardens, as it is always sure to form fine, solid heads, and is the largest heading of all the early varieties. Produces about 300 barrel crates per acre. Not quite so hardy as Jersey Wakefield. A popular cabbage and grown quite scientifically in the South. Originated by a pioneer cab bage grower of South Carolina. Packet 10c; oz. $\$ 1.00 ; 4$ ozs. $\$ 3.00 ; 1$ lb. $\$ 10.00$.

COPENHAGEN MARKET-A new cabbage in enormous demand throughout the cabbage world and in limited supply. Three or four days later than Charleston Wakefield, but it is round-headed (and not cone-shaped), and are larger in size. They weigh an average of 10 pounds, and frequently 14 to 16 pounds. The earliest of all the roundheaded cabbages,. Our truckers are taking rapid and large hold of this splendid new cabbage. The field yield is high, and $95 \%$ head all at

GEORGIA EARLY TRUCKER-For market gardener or planter; one of the best; large size, handsome color; fin market flavor; does not run to seed; largely used by South Carolina sea coast shippers. Pkt. 10c; oz. 75c; 4 ozs.

EARLY WINNINGSTANDT-A Prussian cabbage; standard cone-shaped, solid head; second early variety. Pkt $10 \mathrm{c}$; oz. $90 \mathrm{c} ; 4$ ozs. $\$ 2.50 ; 1 \mathrm{~b}$. $\$ 8.00$.

EARLY IARGE YORK-For very early sowing; an old English variety; heads small and slightly heart-shaped; rather dwarf; can be planted cosely -8 inches in row. Packet 10c; oz. 90c; 4 ozs. $\$ 2.50 ; 1 \mathrm{~b}$. $\$ 8.00$.

WILLET'S ALL-SEASON SUREHEADER-Surehead has all the individual type of the large Flat Dutch and emanated from that variety by selection. Is popular with all for its size and sure heading. One of the finest for second early or late sowing. Grown quickly to a large size and heads surely. It is a true, sure, hard-header. Its name is an index of its character. Packet $10 \mathrm{c} ;$ oz. $75 \mathrm{c} ; 4$ ozs. $2.00 ; 1 \mathrm{~b} . \$ 6.00$.

IMPROVED EARLY FLAT DUTCH-Not so early as the very earlier and not so heavy as some, but very salable because of its flat shape; very extensively planted; weighs from 10 to 12 pounds. Packet $10 \mathrm{c} ;$ oz. $75 \mathrm{c} ; 4$ ozs. $\$ 2.00$; 3. $\$ 6.00$

IMPROVED EARLY DRUMHEAD-An intermediat kind between the cone-shaped early and late varieties; can be planted closely; takes its name from its shape. Packet $10 \mathrm{c} ;$ oz. $75 \mathrm{c} ; 4$ ozs. $\$ 2.00 ; 1 \mathrm{~b}$. $\$ 6.00$.

CAROLINA WINTER-Grown and highly prized for many years below Augusta. Deserves widest and universal use throughout all the South-dependent as we are upon the North and Europe for cabbage seedusually small-head cabbage. Exploited and only listed by this house. The largest of all cabbares and the only cabbage that for the grower seeds in the South and reproduces itself (cut off the heads and eat them and the plant duces itself (cut off the heads and eat them and the plant
will grow out and go to seed for saving). Absolutely never cold-killed. Is of immense size; often 3 to $3 \frac{1 / 2}{2}$ fee across; sometimes ruris 15 to 18 to $20 \mathrm{lbs}$. Augusta truckers have wholesaled them in Augusta at 15c per headretailed at $25 \mathrm{c}$. Have high (18 inches) stems, and with a small green outer fringe resembling a collard. aig center is hard, firm, white and solid. Th heads are round like Flat Dutch. Plant in March or April and no later than May 15th. Price, pkt. 2.5. 2.50. 1 lb. $\$ 8.00$

GREEN GLAZED-For late sowing; glossy green leaves; not so liable to insect attacks, and especially adapted for hot climates. Packet $10 \mathrm{c} ;$ oz. $90 \mathrm{c} ; 4$ ozs. $\$ 2.50$. ib. $\$ 8.00$.

BUNCOMBE, Or NORTH CARO LINA WINTER A firm, solid header, and keeps well; either a spring or winter cabbage. Packe 10c; oz. 90c; 4 ozs. $\$ 2.50$; 10 PREMIUM LATE DRUMHEAD - Sow in Sept.; very hardy and withstands cold; large round heads, though sometimes flattened on top well known. Packet $10 \mathrm{c}$; oz. 75c 4 ozs. $\$ 2.00$; 1 b. $\$ 6.00$.

PREMIUM LATE FLAT DUTCF -The old favorite for fall and win ter sowing; grows low to ground heads large, bluish green in color; broad and flat top. Packet 10c oz. $75 \mathrm{c} ; 4$ ozs. $\$ 2.00 ; 1 \mathrm{~b} . \$ 6.00$. One Acre in Cabbages should make 5,000 heads at about 4 to 5 pounds each, or ten tons of fine sounds each, or ten tons of fine 
cattle. What better could you ask? No food crop is more indicated for the farm than are cabbages, and cabbage plants are dirt cheap. Every farmer should grow at least plants are dirt cheap. The use of cabbage saves meat-eatin a not only for the family, but for the hands of the farm. ing, not only for the family, but for the hands of the farm. There can be no oret

Sog and cattle food. cabbage, pronounced by experts the most perfect type
Don't wait for showers, but keep the Planter going every day regardless of weather and by using water or liquid fertilizer you will produce the best stand of plants ever seen. This system of planting is guaranteed to be proof against cutworms or your money back.

Especially adapted for new land, either stumpy or stony. Satisfac-
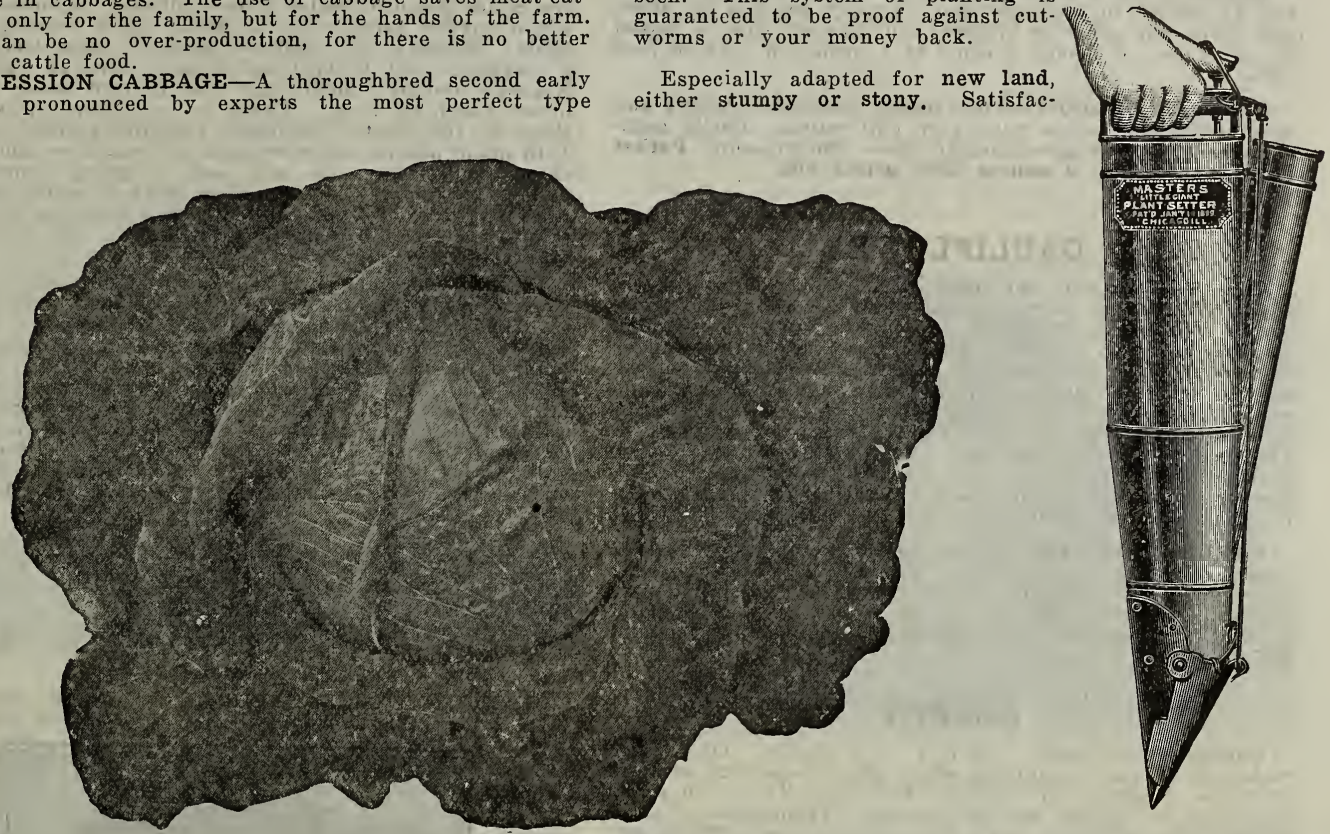

Succession Cabbage.

grown. Especially recommended on account of its uniform size. One of the surest varieties to make a crop under all conditions and does well in all seasons, no matter when planted. The earliest header among flat varieties; 10 days later than Charleston Wakefield; more delicate A popular later than Charleston Wakefiar cabbage, Sometimes have complaints in the market of this cabbage being too large (sometimes 20 pounds), but this fault can be easily overcome by planting them thicker. Packet $10 \mathrm{c} ; 0 \mathrm{oz}$. 75c; 4 ozs. $\$ 2.00 ; 1 \mathrm{~b}$. $\$ 6.00$.

WILLET'S EARLY CABBAGE PLANTS. BY EXPRESS (Frost Proof)

Delivery October to April 15th. Our plants are from seed sown in open fields on the Carolina and Georgia coasts, and are frost-proof. "Frost-proof"' refers to plants when just set out; it does not refer to plants that have grown off and have absorbed in warm weather a heavy succulent watery growth easily attacked by frost.

We ship millions of cabbage plants; do an immense business in them, and can figure on largest orders, October to April, also in midsummer. All varieties. Read "Cabbage plants-Parcel Post,' just below for method of growing. All cabbage plants are cash with order, and no plants are shipped C. O. D. $1,000 \$ 2.50 ; 2,000 \$ 2.25 ; 5,000$ to 10 ,$000 \$ 2.00$ per 1,000 f. 0 . b. grower, for express shipment.

\section{WILLET'S CABBAGE PLANTS}

\section{BY PARCEI POST PREPATD (Frost Proof)}

Grown from the best of Long Island grown seed and not imported seed; shipped direct from our growing station in Carolina by parcel post or express-shipment from November to April 15th. The plants will be somewhat wilted and have a hard, stunted appearance, disappointing to the sight, but regardless of appearance, they will produce results. Transplant deep, up to first leaf, in deep; rich soil, and water plants well. Set out 2 to 3 feet in row; rows 30 inches apart; 7,000 to 8,000 plants per acre; ready for use in 100 to 160 days. Varieties: Jersey Wakefield, Charleston Wakefield, Succession and Early Flat Dutch. Terms, cash with order. No plants shipped C. O D. Price: $100,200,300,50 \mathrm{c}$ per $100 ; 500$ for $\$ 2.00 ; 1,000$ for $\$ 3.25$ by parcel post, prepaid.

FOR A SUCCESSION, CABBAGE can be followed by pole or butter beans about June 15 th, and by kale or extra early peas in September.

\section{MASTER'S PLANT SETTER}

Can set, water and fertilize more plants than three men can set by hand. Every plant securely rooted by absorption-Nature's only way. No blank. No stooping. No more lame backs. tion guaranteed or money back. Get literature and see how it's done. Sets 5,000 to 10,000 plants a day-cabbages, sweet potatoes, tobacco, tomatoes, pepper, collards, etc. $\$ 5.50$ each.

\section{CARROTS}

Culture-One ounce plants a 100 -foot row; 3 pounds an acre. Soil must be fertile deeply dug and light or sandy.

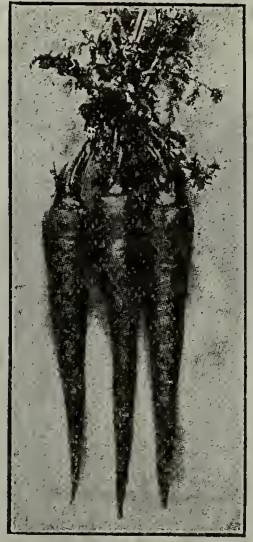

Improved Long Orange Carrot.

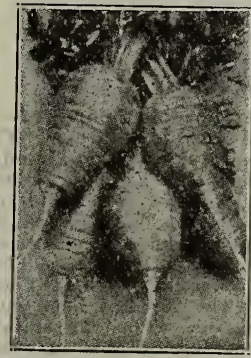

Chantenay Carrot. Soak seed well. Sow in drills from March to November; press down, thin out from 2 to inches so plants can b inches so plants can be worked. Best time for planting August to October.

Digestible, wholesome, with six times more nutriment by weight than Irish potatoes Boil without peeling. Valuable in stews and soups, as its pectin stews and soups, as its pectin makes them easily digested.

For Succession, Carrots, followed by egg plants in June, and by turnips or other greens for salad in the fall.

IMPROVED LONG ORANGE -A standard late variety; handsome and uniform in shape deep orange color; good flavor: yields heavily; requires deep soil; plants should stand 8 ins. apart in 18-in. drills for roots to attain full size. Packet $5 \mathrm{c}$; 1 oz. $15 \mathrm{c} ; 4$ ozs. $40 \mathrm{c}$; pound $\$ 1.00$.

CHANTENAY-Deep Scarlet of uniform shape; a heavy yielder and of fine table quality; grows 5 to 7 inches long. Packet $5 \mathrm{c}$; ounce $15 \mathrm{c}$; 4 ounces $40 \mathrm{c}$; pound $\$ 1.00$.

HALF-LONG DANVERS-One of the most productive, and suits all kinds of soils. The roots are smooth and handsome, a deep orange color, medium length, tapering to a blunt point. The flesh is sweet, crisp and ounces $40 \mathrm{c}$; pound $\$ 1.00$ tender. Packet 5c; ounce 15c; 4 


\section{CARROTS FOR STOCK}

Culture-Sow 3 pounds to the acre. These roots are often 15 inches in circuinference; greatly enjoyed by stock and gives fine color to butter. 500 bushels can be raised on one acre. 1 bushel is equal to 1 bushel of corn in feed value.

BELGIAN YELLOW-The largest, heaviest eropping and most nutritious yellow variety in cultivation. Easily gathered, as the roots grow largely above the ground. Packet $5 \mathrm{c} ; 1$ ounce $10 \mathrm{c} ; 4$ ounces $25 \mathrm{c}$; pound $50 \mathrm{c}$.

\section{CAULIFLOWER}

Culture-Grows on soil adapted to cabbage; same methods of cultivation answer. Seed should be sown in December in cold frame or hotbed, and plants wintered over and made as hardy as possible. Put out just as early as danger of hard freezes have passed. Rapid cultivation is necessary to bring the plants to head before hot weather. Heads will be improved if the leaves are tied over it when beginning to form. One ounce for 1,000 plants. Ready in 95 to 120 days. Market for May 15th to July 15th; October 15 th to November 15 th. Also plant September 1st for December and January and this fall planting (in large use in Louisiana) is the better one for the South.

EARLY SNOWBALI-Plant 30 inches apart each way; very early and very reliable for heading, besides being very dwarf in its habits of growth and very short outer leaves. Imported directly by us from the best Holland grower. Packet $25 \mathrm{c}$; ounce $\$ 2.50 ; 1 / 4$ pound $\$ 8.00$; pound $\$ 25.00$.

\section{CELERY}

Culture-Germinates within 1 to 2 weeks. One ounce makes 4,000 plants, 100 feet drill. Four ounces to an acre. Grown extensively for market. Sow April, May and June, and also in August and September. Transplant when 6
inches high in 3 -foot rows, 6 inches in row. When tall enough they should be covered with earth to bleach. Ready for use in 140 to 175 days. Market September to January 15th. Plant celery in Florida August to November.

BCSTON MARKET-Dwarf branching variety grown s ? extensively about Boston. Solid, crisp and of excellent flavor; its compact dwarf habit allows closer planting and requires less earthing up than taller sorts. Packet $5 \mathrm{c}$ ounce $30 \mathrm{c} ; 4$ ounces $75 \mathrm{c}$; pound $\$ 2.50$.

WFITE PLUME-The stalk and portions of inner leaves and heart are naturally white; needs very little earthing up; crisp, solid, and of a pleasing nutty flavor; its white, feather like foliage is very ornamental. Packet $5 \mathrm{c}$; ounce $\$ 2.50$.

G $O$ I D E N SELF BLANCHING - A selfblanching variety of the White Plume type; ready for use nearly as early; bleaches as easily and is larger in size, as well as finer in quality; of crisp, tender and of fine flavor, keeps well. Packet $10 \mathrm{c}$; lb. $\$ 5.00$.

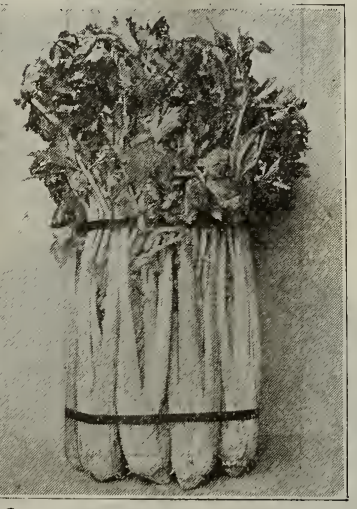

Celery.

\section{GEORGIA COLLARDS}

Georgia Grown Seed-United States Seedmen SuppliedGeorgia grows Collard Seed for the United States. We are large Collard Seed-growing contractors. We have made sales repeatedly, each carrying a sufficiency of seed to plant 60,000 acres in Collards. The Collard is a kind of cabbage that never forms a compact head. The Collard is among the most valuable of vegetables (and the cheapest kind known), growing in any kind of fertile soil. The vegetable is fit for food from a plant 10 inches in height up to a stalk of 3 to 5 feet. Then after the top has been cu off, the young, crisp sprouts springing out from the stalks are a delicious dish. The Collard is most palatable in winter after a keen frost. Properly boiled the winter-crisped leaves may be partaken of with keenest relish.
Planted in Augusta last of June they escape worms; cut and thin out in August and September, if drilled. Plants will keep growing till spring. Every farmer's garden in the South Atlantic States grows collards. Thousands of the negro garden patches in the South grow nothing but Collards. Negroes eat "Collard greens" three times a day; a market 5-cent Collard boiled lasts through three meals. Negroes moving North miss the Collard more than any Negroes moving North miss the Collard more than any other Southern food. There is no cheap equivalent for
them in the North. Cabbage Collards planted here July them in the North. Cabbage Collards planted here July three feet across the top and weighing sometimes 15 pounds per plant. The principal market garden crop about this city. Are by many liked better than the cabbage, or any other green boilcd stuff. Ready in 125 to 160 days. Market October to February.

Culture-An ounce produces about 1,000 plants 150 feet row. Sow spring or summer as for cabbage, either in beds, to transplant when large enough, or in rows where intended to stand. Rapid growers about Augusta; seeds planted in spring, thinned out April 20th, make plants by June 15 th, 3 feet in diameter, weighing $63 / 4$ pounds. Several fcet each way ought to be given the plants. Plant Collards in Florida, January and February, September and October. Sixteen ounces seed for one acre. For cabbage actober. Sixteen ounces seed for one acre. For cabbage with solution of arsenate lead. For lice use "Black Leaf 40 .,

For Succession-Collards can be followed by tomato, pepper, egg plant, about June 1st to June 15th; and by onion sets, turnips for salad, mustard or kale in September and October.

GEORGIA BLUE STEM COLLARD-The old-fashioned kind, known for a hundred years or more. Packet 5c; ounce $15 \mathrm{c} ; 4$ ounces $30 \mathrm{c}$; pound $\$ 1.00$.

GEORGIA WHITE CABBAGE COLLARD-Whiter and more tender than the Blue Stem. Introduced fifteen years

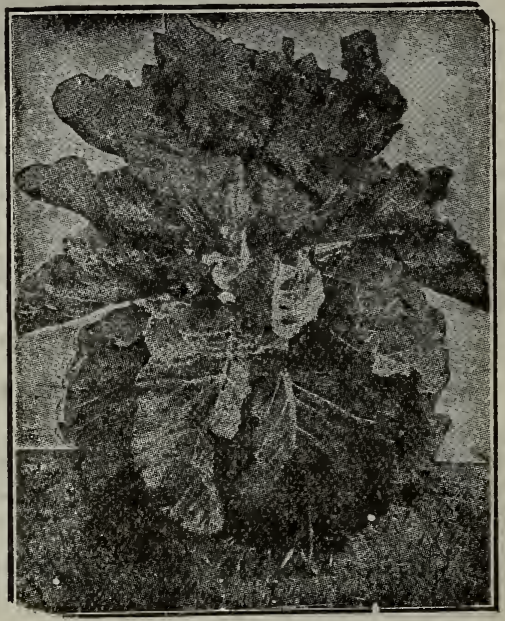

Georgia White Cabbage Collard.

ago. Three-fourths of them bunch or head up in winter weighing 10 pounds or more. Plants grow about 30 inches or more high -30 to 40 inches across. Read Collard culture above. Packet $5 \mathrm{c}$; ounce $15 \mathrm{c} ; 4$ ounces $30 \mathrm{c}$; pound $\$ 1.00$.

COLLARD PLANTS.

COILARD PLANTS delivered May 1st to November 1st; cash with order, as follows: By Express 500 for $\$ 1.00$; 1.000 for $\$ 1.75 ; 3,000$ at $\$ 1.65 ; 5,000$ at $\$ 1.50$ per 1,000 By Postal Pack 3,000 . By Postal Package, postage prepaid, $100,200,300,40 \mathrm{c}$ prepaid. No plants sent C. O. D. We sell enormous amounts prepaid. No plants sent C. O. D. We sell enormous amounts them yourself.

\section{CANTALOUPE or MUSKIMELON}

Culture-Prepare hills, 4 to 6 feet apart, in a rich, moderately dry sandy soil. When frost is over, plant 10 to 12 seeds in each hill and when well up, thin out, leaving 4 strong plants to the hill. To have more and better fruit, pinch off the ends of the vines. Give frequent shallow cul tivation till vines cover ground. Dust with sifted ashes or air-slacked lime to keep. off insects. Do not grow near cucumbers, squashes, etc. One ounce plants 50 hills; two pounds to one acre. Plant cantaloupes in Florida January to May. Plant April 1st to June. As against insects, plant every 16th row in squashes and also end of each row 
After crop is gathered turn in hogs. For leaf blight use Bordeaux Mixture. For Melon Aphis use Black Leaf 40. See insecticide page.

Note-A great commercial truck crop. Planted in open ground, March 25 th, ripening about June $22 \mathrm{~d}$; produces about 60 crates per acre; crates $12 \times 12 \times 24$, holding average 45 melons. Fertilizer is same and amount to same as given for truck cabbage. Up-to-date truckers plant pink flesh or

salmon varieties.
ROCKYFORD NETTED GEM CANTALOUPE-Our seed grown for us at Rockyford, Colorado, where we have the

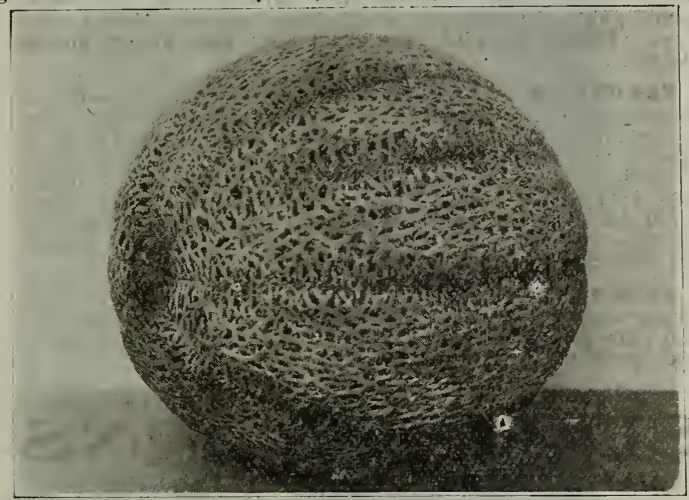

Rockyford Cantaloupe.

largest contracts. Melon is small, sweet and can be eaten to to the rind; distinctive flavor; prolific. Meat light green. Fine grain, spicy and sweet. Seed cavity triangular. Has made 300 standard crates from one acre. Continues long
in bearing. The melon is small. Packet $5 \mathrm{c}$ and $10 \mathrm{c} ; 4$ ounces $30 \mathrm{c}$; pound $\$ 1.00$. Special prices to heavy growers. EDEN GEM, or NETTED ROCK, or POLLOCK-Our seed from Colorado; big improvement over Rockyford Netted Gem: more solid and hard; stands shipping better, stays in condition longer, holding hardness and flavor; vines bear longer and more; small cavity; netting covers whole melon. The melon is small. Price per packet $5 \mathrm{c}$ and $10 \mathrm{c} ; 4$ ounces The melon is small. Price per packet $5 \mathrm{c}$ and $10 \mathrm{c}$;

HOODOO CANTALOUPE-Full large. Serves well cut halves. Deep salmon or orange, and colors to rind. In tremendous use in New York and Atlantic City hotels, and one of our choicest musk melons. Shape rounder than R. F. Gem: deep thick flesh, fine grained and of sweetest flavor. Prolific: resistant to blight. Fine shipper. Packet $10 \mathrm{c}$; 4 ounces $40 \mathrm{c}$; pound $\$ 1.25$.

NEW FORDHOOK, or SWEET MARTHA CANTALNUPE - The principal Cantaloupe used in Atlantic City. All hotels and restaurants using one-half melon for a "help,",

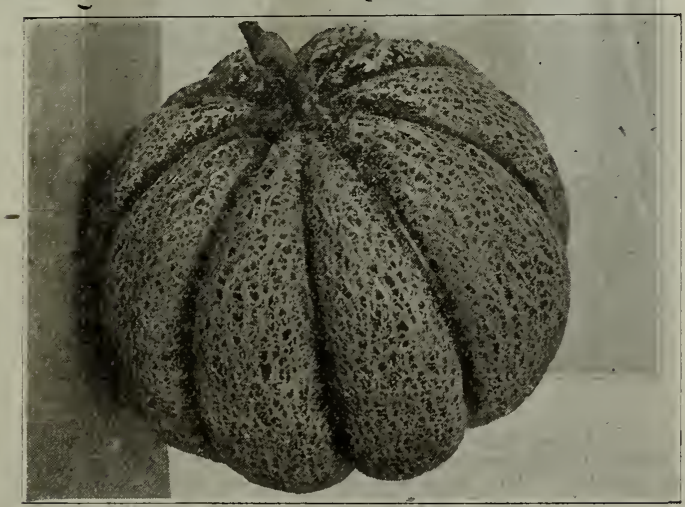

Sweet Martha Cantaloupe.

have discarded the small green flesh melons for the larger salmon flesh-the New Fordhook being the best of the types and large enough for two "helps" at restaurants.

A large grower says: "The New Fordhook Cantaloupe is the most perfect Cantaloupe I ever saw. It is about the same size as Improved Jenny Lind, very thick flesh, of orange yellow, very small seed cavity, comparatively few seeds, flesh very solid and of very high flavor, flesh staying solid and firm after melon has become quite yellow, making it an excellent long-distance shipper. The vines are ing it an excellent long-distance shipper. The vines are $1 / 2$ bushel measured; setting fruit close to hill and keeps on setting fruit throughout season to end of vine. Well ribbed, heavily netted, weigh about $1 \frac{1 / 2}{2}$ to 2 pounds apiece." " One-third larger than Rockyford, flavor quite different and better. Skin yellow, green markings. Sometimes weigh 4 pounds. Augusta truckers have discarded all else.

Hotel Chelsea, Atlantic City, N. J., writes: "'The cantaloupes have given us better satisfaction than any that we have been able to obtain heretofore. They have a most excellent flavor.

Our grower says: "All the big hotels in Atlanta, Ga., paid me a premium of $\$ 1.00$ per crate and used no other."

The best melon grower in N. J. says: "Fordhook is unlike in shape the Rockyford; considerably larger and a

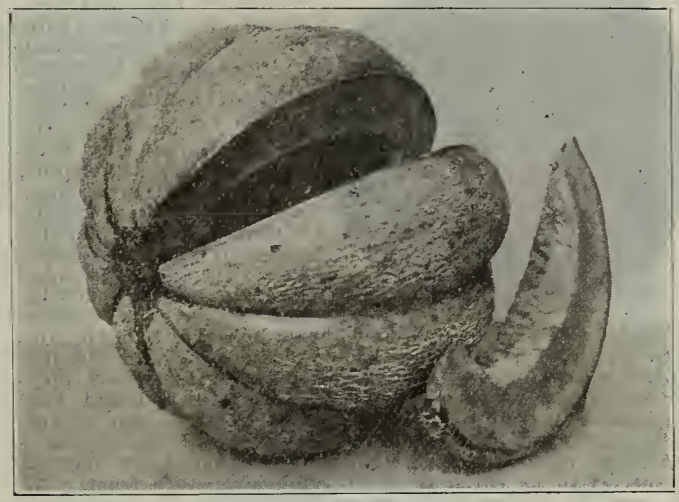

Nixon Cantaloupe.

much better melon in every way.', Price: Packet 10c; ounce $20 \mathrm{c} ; 4$ ounces $50 \mathrm{c} ; 1$ pound $\$ 1.50$

THE NIXON-(A Georgia Cantaloupe)-Georgia grown seed, pure type. Originated in this county. Weighs 7 to 10 pounds; flesh crisp and sweet; rough skin, good shipper; deep ribbed; rind and flesh green-yellow. The prime favorite for 20 years in the Augusta market. Is especially liked because of its large size, combined with the finest flavor. Sweetest and best home melon known. Too big for Northern shipping. Our seed are carefully selected and true, and Round shape, thick meat, purely a Southern melon, always Round shape, thick meat, purely a Southern melon, always
brings a fancy price wherever sold. No home or one's home market melon is comparable to it-size and sweetness and crispness considered. The market here is never half supplied, so large is the demand, and it retails quite frequently in Augusta at $25 \mathrm{c}$ each. Packet $5 \mathrm{c}$ and $10 \mathrm{c}$; ounce $20 \mathrm{c} ; 4$ ounces $60 \mathrm{c}$; pound $\$ 1.75$.

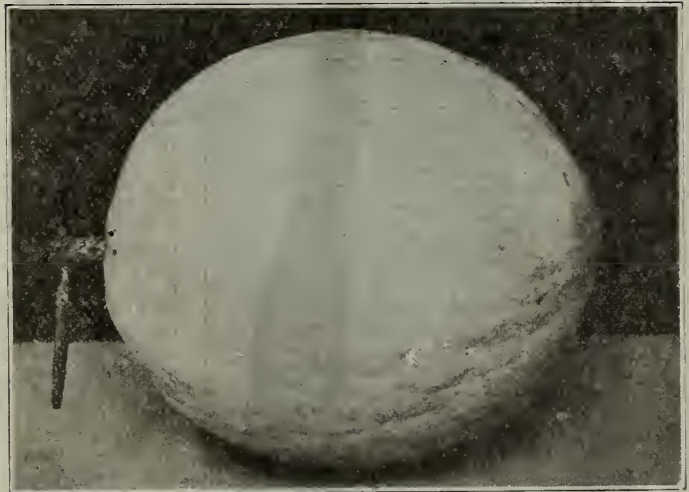

Honey Dew Cantaloupe.

HONEY DEW CANTALOUPE-See cut of 61/2-lb, melon. Photo taken at Augusta. The average size of the melon, 6 inches in diameter and 7 to 8 inches in length and weighs from 5 to 6 pounds. Skin is smooth with an occasional net, and is a creamy yellow when ripe. The flesh is green and very thick and fine grained, and can be eaten to the extreme rind. The seed cavity is very small, the rind impervious to water. The melon does not shrink in weight. It matures about 10 days later than the Rockyford strains, and is very prolific. The melon slips from the vine when ripe and will keep for several weeks, the late-maturing melons keeping until Christmas. The rind 
does not absorb water. The melon is very nutritious, as it runs as high as 10 per cent sugar. This amount of sugar helps preserve it, and in connection with its self-hermetically sealed rind makes it a very long keeper. Pack in $1 / 2$ Packet $10 \mathrm{c} ; 1$ ounce $15 \mathrm{c} ; 4$ ounces $50 \mathrm{c} ; 1$ pound $\$ 1.50$.

\section{Winter Casaba or Mexican Cantaloupe.}

WINTER CASABA, Or MEXICAN CANTALOUPELargely grown in California, which ships in December and January large amounts to New England markets. They

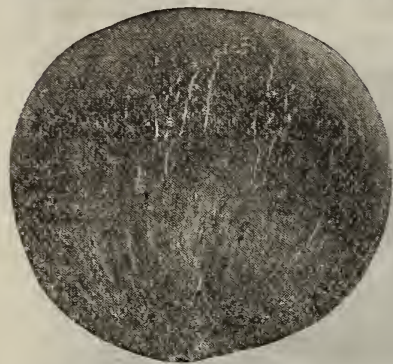
each. Size about 24 inches in circumference, round in shape; thin rind; flesh yellow cream white; soft and delicious. This is the famous "Sarda," or Sweet Melon of Afghanistan. Do not confound this with the Summer Pineapple Casaba-a different melon. The Winter Casaba yellow, green and ridged. Keep four or five months Keep four or five months Winter Casaba-6 $1 \frac{1}{2}$ Pounds. all the while. An Augusta party says: "Had splendid success with Casaba planted in new ground, and planted every few weeks during the late part of spring until July 1st, and had fine cantaloupes from the last of June until frost." See cut of $6 \frac{1}{2}-1 \mathrm{~b}$. melon. Culture-Plant late spring till last of June. Late ones ripen in September and can be kept several months. Can be eaten from the vine, or before frost, pull and store in outhouses. Fine for home use or shipping.

\section{Market Garden Corn}

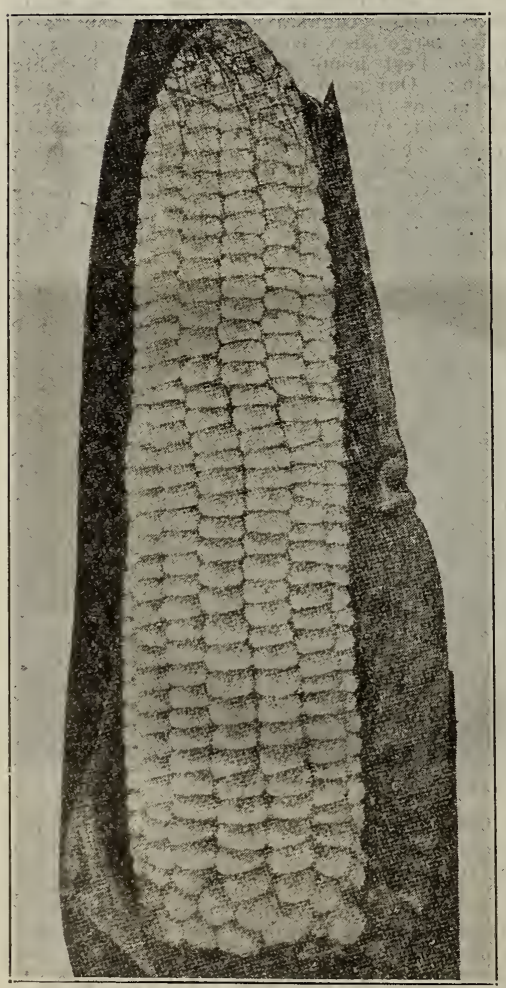

Trucker's Favorite. frequent, but
For Succession-Sweet Corn can be followed by sweet potato cuttings about June $15 \mathrm{th}$, can be followed by rape, onion sets or cabbage plants or lettuce plants in fall.

EXTRA EARLY ADAMS-(Not a Sugar Corn)-The earliest white corn in cultivation; makes a small ear and stalk, can be planted close together. Packet $5 \mathrm{c}$; pint $35 \mathrm{c}$ quart $65 \mathrm{c}$; peck $\$ 3.00$; bushel $\$ 10.00$.

EARLY ADAMS, or BURLINGTON-(Not a Sugar Corn) - Similar to Extra Early Adams, but a little later, and makes larger ears. Earlier and hardier than the suga corns, and as it makes a small stalk, can be planted very close. Packet $5 \mathrm{c}$; pint $35 \mathrm{c}$; quart $65 \mathrm{c}$; peck $\$ 3.00$; bushel $\$ 10.00$.

TRUCKER'S FAVORITE-(Not a Sugar Corn)-For a second-early; to follow Early Adams, unquestionably one of the best; or for planting late to mature quickly it is equally valuable. Is a white corn with a very good depth of grain sweet, and makes a most desirable size for roasting ears. Most market men prefer the largeeared table corns. Fine field corn, too, for late planting. 65 days for roasting ears and 80 days for meal. Packet $5 \mathrm{c}$; pint $25 \mathrm{c}$; quart $40 \mathrm{c}$; peck $\$ 2.00$; bushel $\$ 6.00$.

SNOWFLAKE CORN-(Not a Sugar Corn)-The universal Augusta market table corn, white, juicy, productive and ears as big as field corn. Packet $5 \mathrm{c}$; pint $25 \mathrm{c}$; quart $40 \mathrm{c}$; peck $\$ 2.00$; bushel $\$ 6.00$.

\section{SUGAR CORNS}

NOTE-Cook soon after pulling, as after pulling the sugar quickly changes to starch in the grains. Space $3 \mathrm{ft}$. in rows and 18 inches in drill. As sweet corn rapidly dries out we, therefore, sell them not in pounds, but by the measure.

COUNTRY GENTLEMAN-For middle season and late use. Irregular rows. Long slender shoe peg grains. Ears

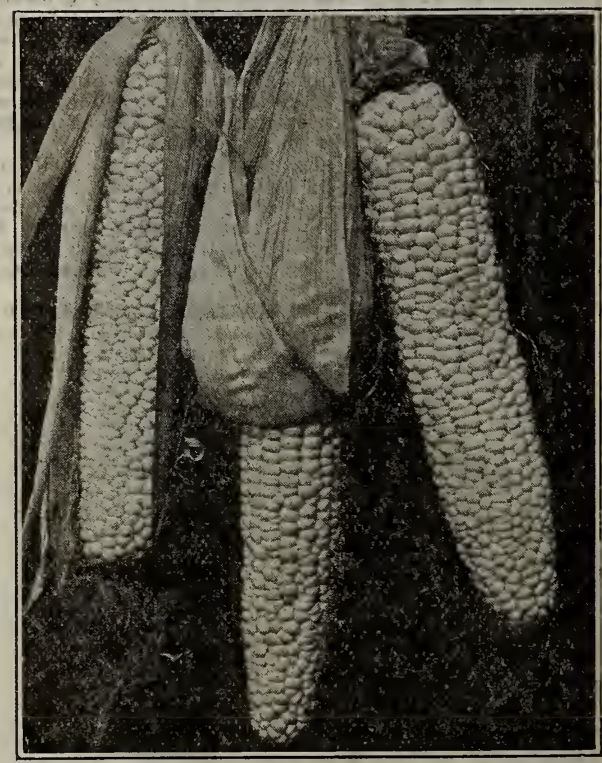

Country Gentleman Corn.

tem. D ril and feed ears b l a d e and stalk for early forage crop in green state, the suckers this gives the earliest perfect ration forage $c r o p$ n u a r t plants q u a r t plants 8 quarts 6 to 8 quarts one a c r e. Add corn, at rate 1 pound per pint.

CUITURFrich, w a $r \mathrm{~m}$, soil. Plant in corns are tennot be plantis warm. Give vation a $n$ d plantings a two weeks for roasting ears. 70 to 95 days. Market M a $\mathrm{F}$ or roastin ears, take off the s u c k e plant and and one of the best Sugar Corns known. While it has not been on the market as long as some, it is today the most popular. The ears are not only of good size, but are produced in great abundance frequently yielding three or four good ears to the stalk. Its quality is unsurpassed. Packet 5c; pint $45 \mathrm{c}$; quart $80 \mathrm{c}$; peck $\$ 5.00$.

WILLET'S GOLDEN SWEET CORN, or "BANTAM"Very early, and a tender table corn. Remains on the stalk longer without getting hard than most white varieties. It is very prolific and hardy. One of the great favorites in New England and rapidly supplanting the white varieties. Quite a number of our customers claim it the tenderest and sweetest table corn they have ever planted. Price, packet $5 \mathrm{c}$; pint $45 \mathrm{c}$; quart $80 \mathrm{c}$; peck $\$ 5.00$. IATE MAMMOTH SUGAR-This is the latest, but largest of all the Sugar Corns. The ears are immense, and are of fine quality and flavor. Packet $5 \mathrm{c}$; pint $40 \mathrm{c}$; quart $75 \mathrm{c}$ ! peck $\$ 4.50$. 
STOWELL'S EVERGREEN-For middle season and late use. Practically no other Sugar Corn but this is used at Atlantic City hotels. Extremely large ears, deep large

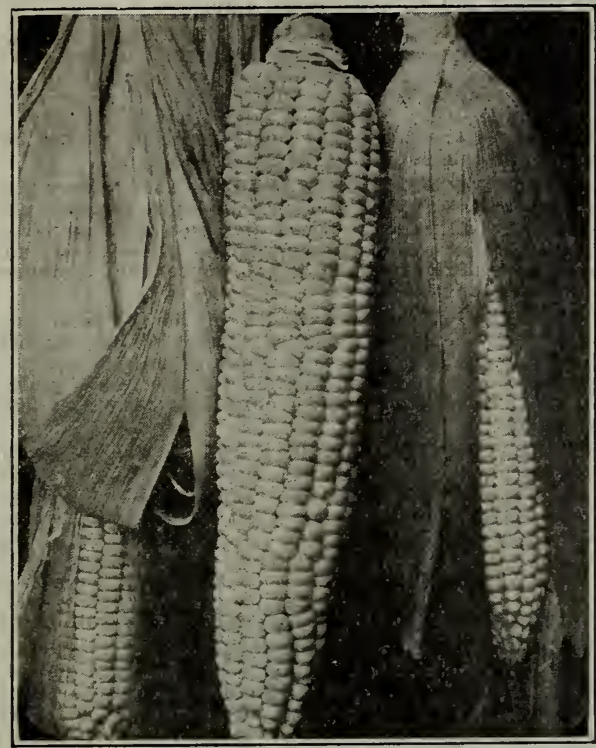

Stowell's Evergreen Corn.

juicy grains and tender. Medium late. This has long been a great favorite. Its strong point is that it will remain in the green state. Very tender and sugary. Packet $5 \mathrm{c}$; pint $40 \mathrm{c}$; quart $75 \mathrm{c}$; peck $\$ 4.50$.

\section{CUCUIMBERS.}

Culture-To have the earliest cucumbers, start in small paper boxes. For general crop, plant in the open ground about the middle of April or first of May, not orer an inch deep, in hills about 4 feet apart each way. The hills should be previously prepared by mixing well-rotted manure with soil. Put ten seeds in each hill, and when all danger of insects is past, thin out to four plants and give frequent, but shallow cultivation. The fruit should be gathered when large enough, whether wanted or not, for if left to ripen on the vine, it destroys its productiveness For productiveness in June pickling, plant in June
or July. Ready in 65 or July. Ready in 65 to 80 days. Market 1 st and October 1st to November 15th. One ounce will plant 50 hills; two pounds, one acre, the pounds, one largely infected with anthracnose, or spots, anthracnose, or spots, with Bordeaux Mixture dry. For Cucumber Aphis, use Black Leaf

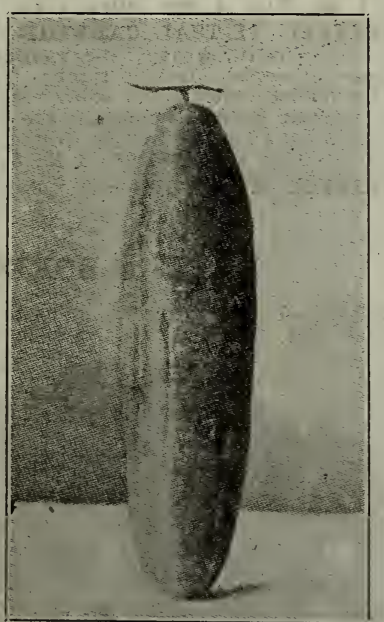

Improved Eárly White Spine Cucumber.
Page. Plant Cucumbers in Florida September to January,

IMPROVED EARLY WHITE SPINE-The well known standard trucker variety. One of the best for the table; tender, crisp, straight and dark green with few white spines. 5 to 7 inches long. Packet $5 \mathrm{c} ; 0 z$. $15 \mathrm{c} ; 4$ ozs. 40c; pound $\$ 1.10$.

KIONDYKE CUCUMBER-The fruit averages about 2 inches thick to 7 inches long, very dark green, striped with light green about one-third the length from the blos. som end. The flesh is waxy white, crisp and of excellent som end. The flesh is waxy white, crisp and of excellent
flavor. Comes in with the extra early sorts, for market gardener abundant yielder. Packet 5c; ounce $15 \mathrm{c} ; 4$ ounces $40 \mathrm{c}$; pound $\$ 1.10$.

EARLY FRAME, or SHORT GREEN -Excellent for table or pickling. 4 to 5 inches long. Fruit straight, handsome, smaller at each end, bright green; flesh tender, crisp, makes fine pickles. Packet 5c; bulk price same as Long Green.

DAVIS' PERFECT CUCUMBERNew, shy seeder and early. Holds color and brittleness long after cutting; disease-resistant; resembles in taste the hothouse product, and brings double price in market. Color is the same as Klondyke, but the fruits are longer averaging 9 to 10 inches long, when in market condition Packet $5 \mathrm{c}^{\circ}$ ounce $20 \mathrm{c} ; 4$ ounces $45 \mathrm{c}$; pound $\$ 1.25$.

CHICAGO PICKLING-The chief

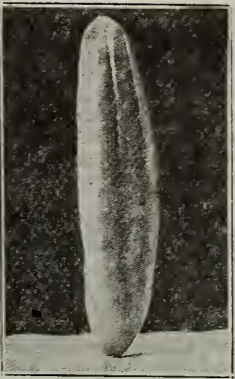
pickling cucumber in the Middle West and California. Carries a special fine Klondyke Cucumber. pickling uality and a very dark green

color. The fruit starts early and continues throughout a long season. The flavor as a pickling matter is delicious. In shape it is 1 inch thick and 3 inches long when at pickling size. Enormously prolific; bears in clusters. Must be used when ready and not allowed to yellow on the vines. Packet 5c; ounce $15 \mathrm{c} ; 4$ ounces $40 \mathrm{c}$; pound $\$ 1.10$.

EXTRA EARLY LONG GREEN-Very early, of attrac tive form and size, very prolific and especially valuable for

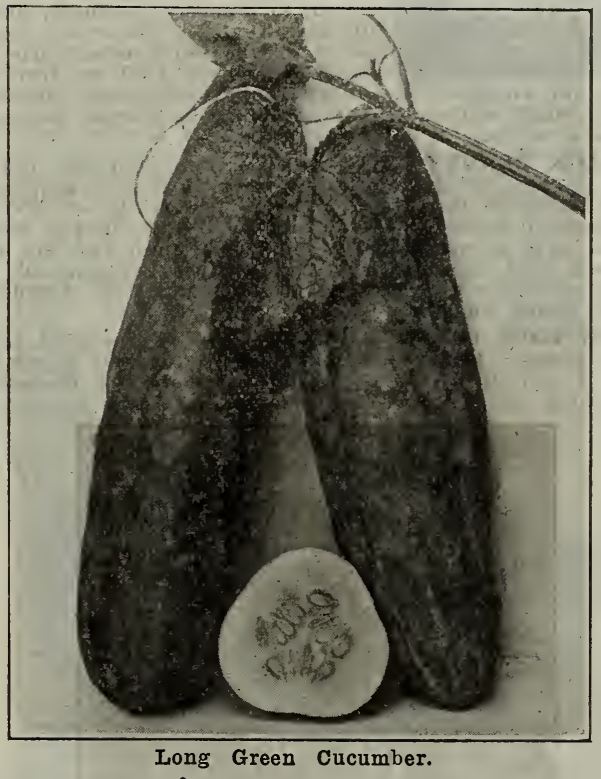

market gardens because of these valuable qualities. Particularly good for pickling. Packet 5c; ounce $20 \mathrm{c} ; 4$ ounces $45 \mathrm{c}$; pound $\$ 1.25$.

GHERKIN-West India or Burr-Used in pickling. Round, green, prickly. Packet $5 \mathrm{c}$; ounce $20 \mathrm{c} ; 4$ ounces $50 \mathrm{c} ;$ pound $\$ 1.50$.

DASHEEN-(See Cut.) The world eats more Dasheen than potatoes. Most easily digested-even an invalid's food. Tubers contain more protein, sugar, starch and fat

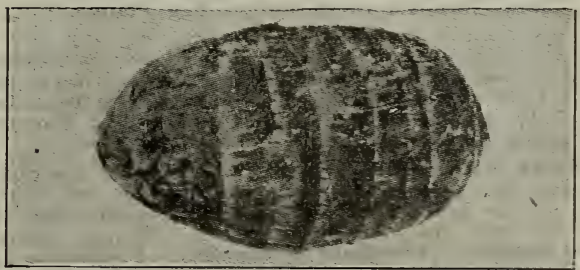

Dasheen. 
than Irish or Sweet Potatoes, and are more productive and keep and "ship" far more easily and safely. Taste like chestnuts. Cook in many ways-usually bake or use as "chips.", Get Farmer's Bulletin on "Dasheen." "Gather. about November 1st. Weight four ounces to three pounds. Require warm, frostless season of six months. Eat big corms; save small for seed; tear bulbs apart, dry for sevcorms; save small for seed; tear bulbs apart, dry for sev-
eral weeks, and bulk, and save. Young leaves make fine "greens"'; young inside white shoots are far better than asparagus. Cooks grayish white and mealy. Requires less time for cooking than the two above potatoes. When scrubbed and baked, eat the soft delicious crust along the inside. Growing the blanched forced shoots from the corms, in the dark during winter like mushrooms, is getting to be also of itself a large industry. (See plant industry circular 127.) In 1917, at Augusta, produced 15 to 18 tubers per hill, some 4 inches in diameter. Horses, cows, hogs, chickens and dogs are all fond of cooked Dasheen. Plant grows 5 to $6 \mathrm{ft}$., produces immense elephant ear leaves and largely ornamental. Our grower says: "I plant in $4 \mathrm{ft}$. rows, 20 ins. between the plants, 4 inches deep, cultivate often and on the level. Some plants grow $6 \mathrm{ft}$. tall; make enough corms per hill to fill $1 \frac{1 / 2}{2}$ peck measure. When the foliage dies November 1st it strips off easily from the corms." Price, peck 90c; bushel $\$ 2.75$.

\section{EGG PLANT.}

Culture-One ounce, 100-foot row. Plant February 1st in hotbed; transfer to cold frame in March, and later to field in growing weather. Mature about June 25th; about 300 bushels per acre. Plant will produce fruit until killed by frost. Set out plants early in warm weather in field in rows $2 \times 3 \mathrm{ft}$. For October to January shipment, seed should be sown during July and August. The result from an acre or two of egg plant at that season is often surprisingly satisfactory. Plant $1 / 2$ pound of seed to furnish plants for an acre. Ready in 100 to 125 days. Market July through winter. Plant egg plant in Florida September to January.

BLACK BEAUTY-Two weeks earlier than any other arge variety, producing large, thick, lustrous, purplishblack fruits of the finest quality. The fruits set freely and develop quickly. It holds its color exceptionally well. Not as large as our strain of New York Improved, but its earliness and splendid shipping qualities recommend it highly to market growers. Packet $10 \mathrm{c}$; ounce $75 \mathrm{c} ; 4$ ounces $\$ 2.00$; pound $\$ 6.00$.

NEW YORK IMPROVED PURPLE-The type most generally grown. Makes a large, thick fruit, having a purple 政

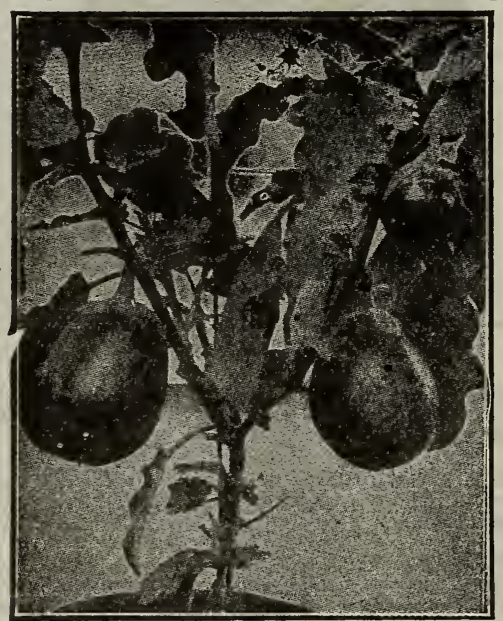

New York Improved Purple Egg Plant.

prickles. These spines or prickles have, by continuous selection of seed parents, been entirely eliminated and the spineless type is now most generally offered. Deep, lustrous purple; standard. Packet $10 \mathrm{c}$; ounce $75 \mathrm{c} ; 4$ ounces $\$ 2.00$; pound $\$ 6.00$.

FLORIDA HIGH BUSH-A great favorite in the South and in Florida. The fruit is large and purple, and is held well up off the ground. It is a splendid shipper and the commission men get high prices for it. Resists drought and wet weather. The plant is vigorous. Productvie and bears profusely. Price, packet $10 \mathrm{c}$; ounce $50 \mathrm{c} ; 4$ ounces $\$ 1.50$; pound $\$ 4.00$.
JAPANESE and CHINESE SEEDS.

For spring and early fall garden sowing. All are excel lent things with genuine great merit, and not the usual novelties to sell and to experiment with.

JAPANESE SPINACH-HORENSO-Of highest quality. Leaves exceedingly large, but very tender and of fine taste. The Japanese believe this to be the best spinach in the world. Sow $1 \mathrm{oz}$ to $100 \mathrm{ft} 8 \mathrm{lbs}$. per acre. Sow early spring and until May, September and August. Ready in 50 days. Leaves are large, but tender. Price, packet $5 \mathrm{c}$ 1 ounce $15 \mathrm{c} ; 4$ ounces $50 \mathrm{c} ; 1$ pound $\$ 1.50$

TURNIP TOKYO SUMMER MARKET-This is very popular and matures quickly, good variety for summer use. Flat round, pure white, solid sweet, and excellent fine flavor. Highly esteemed by the market gardeners. Sow seeds an time in spring. Price, packet 5c; 1 ounce $15 \mathrm{c} ; 4$ ounces $50 \mathrm{c} ; 1$ pound $\$ 1.50$.

TURNIP TENNOJI LARGE BALL-It is the most popular varicty of Japanese turnips. Snow white, smooth globe-shaped and has fine grained flesh of mild flavor. It forms a good root early, even in shape, and of good quality for table use. Price, packet $5 \mathrm{c} ; 1$ ounce $15 \mathrm{c} ; 4$ ounces $50 \mathrm{c}$. 1 pound $\$ 1.50$.

JAPANESE TURNIP (Shogoin)-The largest of all the Japanese Turnips-sometimes 15 pounds. White, solid, sweet. For human use or cattle. Withstands cold, keeps well, shape round and or corte. keeps planting-June, July and August. Carries not only large bottoms, but large tops. We weighed one in Augusta, December last weighing, tops and bottoms, seven pounds-a very beautiful round all white turnip. $1 \mathrm{oz}$. $100 \mathrm{ft} ; 4 \mathrm{lbs}$. an acre. Price, packet $5 \mathrm{c} ; 1 \mathrm{oz} .15 \mathrm{c} ; 4$ ozs. $50 \mathrm{c} ; 1 \mathrm{lb} . \$ 1.50$

JAPANESE RADISH (Mikado)-Large, long, snow white, sometimes several feet in length, or seven or eight pounds. Very sweet and crisp and firm. Slice. Eat raw, or cook, or pickle. Quick-growing. Great favorite. Used in Augusta quite largely by restaurants. August sowing is best. $1 \mathrm{oz}$.to $100 \mathrm{ft}$. Price, packet $5 \mathrm{c} ; 1 \mathrm{oz}$. $15 \mathrm{c} ; 4 \mathrm{ozs}$. $50 \mathrm{c}$; 1 lb. $\$ 1.50$.

CHINESE SANTOSAI-The quickest of growers among all vegetables, a hundred times better than mustard or turnip tops for greens. An enormous producer. Makes head of erect leaves with no stem; for fall quick heading -matures quicker than cabbage. In large use now in America. Leaves fold inward. Leaves thick, fleshy, sweet, tender, white. Can be boiled and served like ordinary cabbage, or can be eaten raw in salads or like celery or lettuce; in immense use in China. It is very hardy; an ideal fall vegetable; carries very much the same looks, being tall and slim and with leaves closely folded together, as Romaine. Fine for growing for poultry use. Price, packet, $5 \mathrm{c} ; 1$ oz. $20 \mathrm{c} ; 4$ ozs. $60 \mathrm{c} ; 1$ lb. $\$ 2.00$.

CHINESE PE-TSAI CABBAGE-Kinchiu type; grows more like head cabbage; the leading and famous Chinese cabbage; compact leaves tightly folded together; easily self-blanching, with heart snowy white; crisp and tender. The quickest grower among all the cabbages and deserving of universal adoption in the United States. Price, packet $5 \mathrm{c} ; 1$ oz. $35 \mathrm{c} ; 4$ ozs. $\$ 1.00 ; 1 \mathrm{lb}$. $\$ 3.50$.

CHINESE MUSTARD-See "Mustard" heading.

\section{KALE or BORECOLE.}

Culture-Used for greens, helps to make a boiled dinner; coarser and rougher than spinach and a larger yielder.

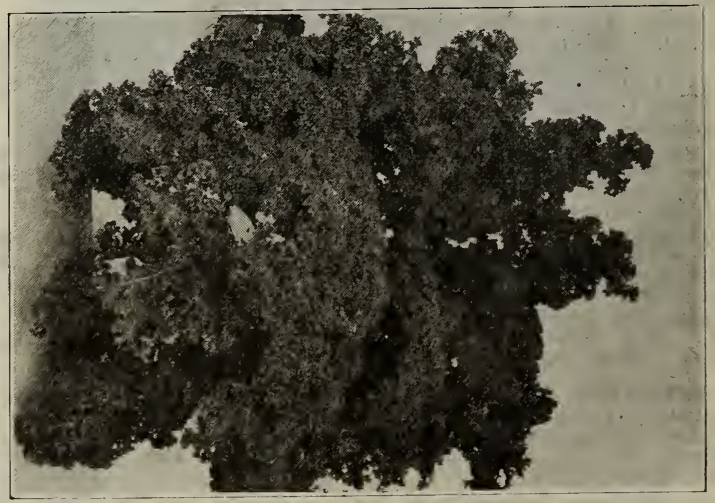

Dwarf Scotch Kale.

Market in the winter. One ounce for 1,000 plants; 8 pounds an acre. For winter greens sow from August to 
October in drills 2 feet apart; thin out to 3 inches in row, and cultivate as cabbage. We plant here August 1st up to November and still through mid-winter up until May 1st. Ready in 90 to 120 days. A quick-growing big market crop. Makes fine chicken food.

DWARF SCOTCH-Curled. Most tender and delicate of all the cabbage family : improved by frost. The leaves look like an immense feather. Grayish-green leaves, which are only slightly curled at the edges; extremely hardy. Packet $5 \mathrm{c}$; ounce $30 \mathrm{c} ; 4$ ounces $75 \mathrm{c}$; pound $\$ 2.50$

TALL SCOTCH-Curled. Similar in growth tothe dwarf, but larger and produces more, equally as tender and fine for market. Packet $5 \mathrm{c}$; ounce $30 \mathrm{c} ; 4$ ounces $75 \mathrm{c} ; \mathrm{lb}$. $\$ 2.50$.

\section{LETTUCE.}

Culture-One ounce for 200 feet drill; 1,500 plants; three pounds to acre. Plant in cold frames February 1 st and set out in ground March 1st, mature about May 1st. Sow in beds almost any month in the year. Reset plants 10 inches apart in row's; force to rapid growth if wanted tender; several crops in one season under glass frames. Ready in 50 to 85 days. Market March 1st to August 15th, and October 1st to December 15th. Plant all the year. For "Soft Rot"' in Lettuce spray with Formaldehyde, 1 pint to 30 gallons of water.

For Succession-Lettuce can be followed May 15th by snap beans, and by endive, parsley or spinach from August 1 st to September 1st. Plant lettuce in Florida October to January.

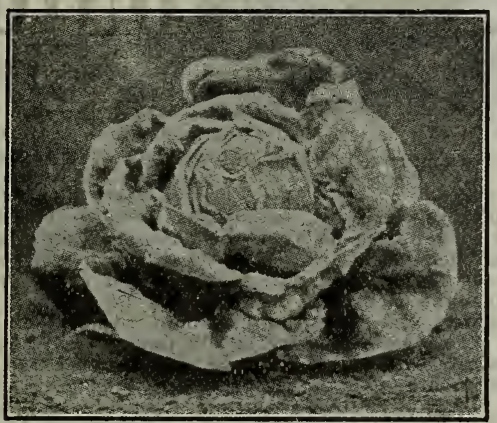

Deacon Cabbage Lettuce.

DEACON CABBAGE-Has large, solid head; cabbage lettuce for summer use. Packet $5 \mathrm{c}$; ounce $15 \mathrm{c} ; 4$ ounces $35 \mathrm{c}$; pound $\$ 1.00$

MAXIMUM, or IMMENSITY-A large heading sort. Prof. R. E. Mansell, of the Experiment Station at the University of California, who plants a very large number of samples annually, pronounces Maximum entirely to lead the list of all lettuces. Packet $5 \mathrm{c}$; ounce $15 \mathrm{c}$; 4 ounces $35 \mathrm{c}$; pound $\$ 1.00$.

MAX KING-A very early new variety, forming fine hard heads within a few weeks after planting. It is medium sized, light green, with buttery, but crisp heads. Packe $5 \mathrm{c}$; ounce $15 \mathrm{c} ; 4$ ounces $35 \mathrm{c}$; pound $\$ 1.00$.

SILVER BALL-The thick, light-green leaves have so much sheen that they actually look silvery white in some much sheen that they actually look silvery white in some
lights. The heads are of good size and fine quality. Packet $5 \mathrm{c}$; ounce $15 \mathrm{c} ; 4$ ounces $35 \mathrm{c}$; pound $\$ 1.00$.

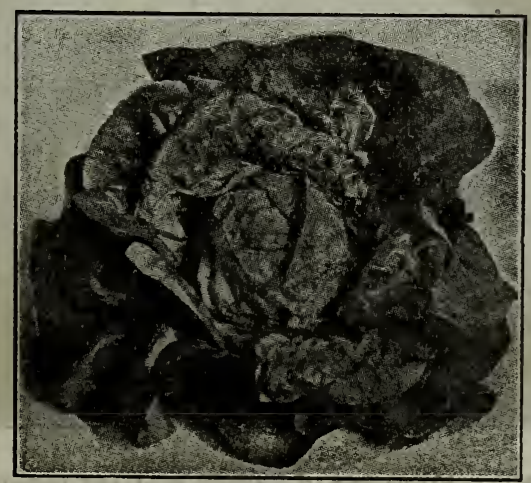

Big Boston Lettuce.

BIG BOSTON-Among the Southern truckers this is more preferred than any other for shipping. Preferred on

account of great size and solidity: Packet $5 \mathrm{c}$; ounce $15 \mathrm{c}$; 4 ounces $35 \mathrm{c}$; pound $\$ 1.00$.

IMPROVED HANSON-Forms large, firm heads, resembling cabbage, which are deliciously sweet, crisp and tender; heads green outside and white within; for outdoor culture unexcelled. Heat resisting. Packet $5 \mathrm{c}$; ounce $15 \mathrm{c}$; 4 ounces $35 \mathrm{c}$; pound $\$ 1.00$.

PARIS WHITE ROMAINE- "Celery Lettuce," or "Cos Lettuce." Now grown with great financial success in Florida and South Carolina lettuce trucking area. Somewhat a cross between lettuce and celcross between lettuce and celery. Plant almost any time with us, except in summer, usually 12 inches in the row and 18 inches between rows. The outside leaves fold in and over. and the inside leaves develop and in this shaded center are and whitened and manched and whitened and rior to other lettuces, because it always carries a special crispness and a tenderness and delicious flavor. Can be sold as a superior form of lettuce. Getting more popular than lettuce because it revives better after shipping, and because it makes more abundantly. The gardeners who get a very fine product out of this variety of lettuce usually tie the leaves together well up on the plant with string so that the inside leaves shall be quite completely blanched, and other gardeners plant the seed quite thick, so that the

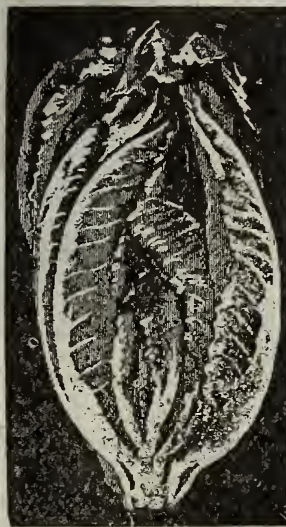

Romaine.

plants support each other and thus hold the leaves together with consequent proportional blanching. Cone-shaped. An exceedingly quick grower and a heavy producer. Price, packet $5 \mathrm{c} ; 1$ ounce $25 \mathrm{c} ; 4$ ounces $60 \mathrm{c} ; 1$ pound $\$ 1.75$.

\section{MUSTARD.}

Culture-One ounce to 100 feet. Sow in fall, winter or spring, in rows or shallow drills. Press earth well down; ready for use in five or six weeks, One ounce, $100 \mathrm{ft}$; 3 to 5 lbs. an acre. An easy, inexpensive vegetable to grow, and its "greens", are in demand in spring and fall; can be put down here all the year around.

For Succession-Mustard can be followed by English peas for late crop about April 1st; and by cabbage plants in August. Plant mustard in Florida any time.

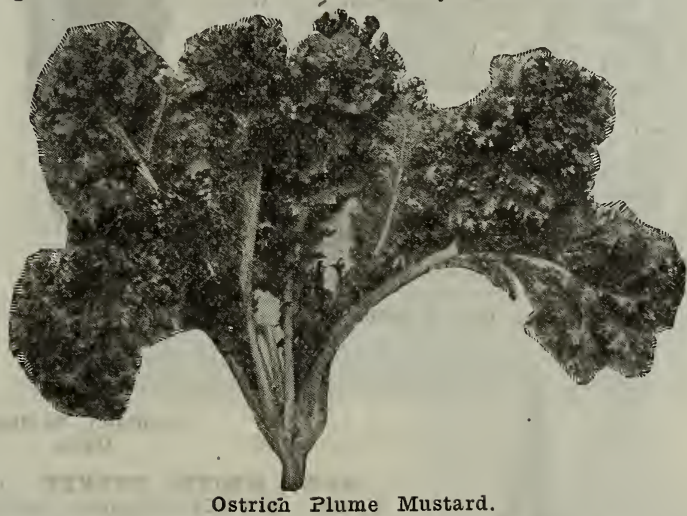

OSTRICH PLUME-Most beautiful mustard grown. Originated in Augusta. It was introduced by us to the seed trade of the United States. Many of them are putting it in novelty lists. Plumes are very tender, very long and fine crimped pretty as an ornamental plant. Looks like ostrich plumes. Plants large, of ten 5 to $6 \mathrm{lbs}$. Packet $5 \mathrm{c}$; ounce $15 \mathrm{c} ; 4$ ounces $35 \mathrm{c}$; pound $\$ 1.00$.

SOUTHERN GIANT CURLED-Highly esteemed in the South; sown in the fall produces enormous bunches. Excellent for salad and very generally used for greens, for which it is largely cultivated. Packet $5 \mathrm{c}$; ounce $15 \mathrm{c} ; 4$ ounces $35 \mathrm{c}$; pound $\$ 1.00$.

FORDHOOK-A strain intermediate in value between $\mathrm{S}$. G. C. and Ostrich Plume. Less curly and larger than O. P. but more curly than S. G. C. Packet $5 \mathrm{c}$; ounce $15 \mathrm{c} ; 4$ ounces $35 \mathrm{c}$; pound $\$ 1.00$. 
CHINESE-A variety producing larger and broader foliage and more succulent stems; of a deeper green color. Packet $5 \mathrm{c}$; ounce $15 \mathrm{c} ; 4$ ounces $35 \mathrm{c}$; pound $\$ 1.00$.

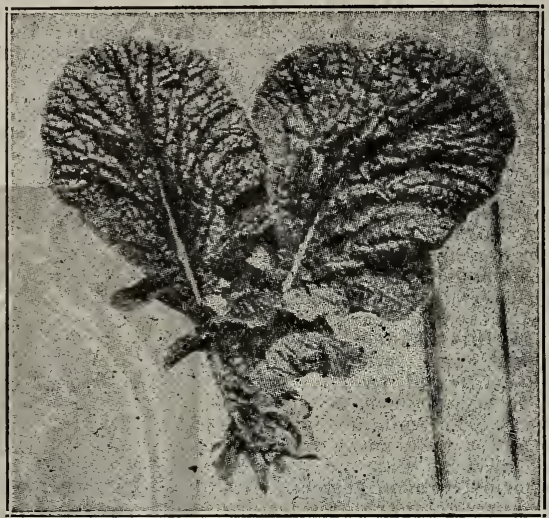

Chinese Mustard.

\section{OKRA.}

GEORGIA GROWN

These seeds are grown in Georgia. We supply the U. S. trade many thousands of pounds yearly. Large amounts dealt in-spot or contract. A staple article of itself, and a necessity in soups and creole jumbo. Flourishes wherever cotton grows and not affected by insect diseases and drought. Prolific; gather continuously the young pods and the plant Prolle; fruits up to frost. ooms and fruits up to frost. $50 \mathrm{ft}$ drill; 8 lbs in spring drills 2 ft apart, and leave one plant to late in spring drills $2 \mathrm{ft}$. apart, and leave one plant to every 15 inches. Cover one inch deep; use in 90 days. Pick off all pods soon as ready and new ones will come.

HUFFMAN'S EARLIEST-Two or three weeks earlier than other Okras; produced after eight or ten years of work through careful selection-two weeks earlier than any selection twonty varieties tested last out of twenty varieties tested last year. Blooms often when plant is no ing oftentimes when the fourth leaf appears; three feet high, and pods six to twelve inches lon.

The Agricultural Department at Washington has taken great interest in this Okra, as have our growers who have tested it this season. It is a dwarf variety and is the earliest of all the usually riety and is the earlest of all the usually sond while dwarf Okras have short pods, and while dwarf Okras have short pods, the Huffman has long pods, very long, and a bright green color. The pods are decidedly angular in shape rather than bearer. Packet 5c; ounce 10c; 4 ounces $20 \mathrm{c}$; pound $60 \mathrm{c}$.

LONG GREEN-Pods are dark green and stalks tall-about 7 feet. Packet $5 \mathrm{c} ; 2$ ounces $10 \mathrm{c} ; 4$ ounces $15 \mathrm{c} ;$ pound $40 \mathrm{c}$.

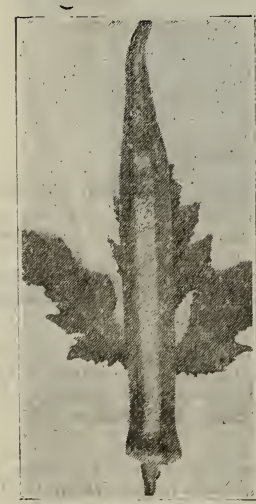

Long Green Okra.

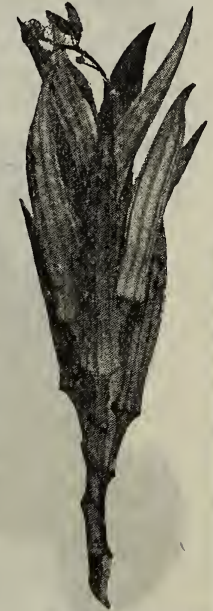

Huffman Earliest Okra.

NEW WHITE VELVET, or IADY FINGER_Tender, white pods, round and smooth; a distinct variety. Height, 5 to 6 feet. One stalk at Augusta, 1914, had 110 pods on it. Packet $5 \mathrm{c} ; 2$ ounce $10 \mathrm{c} ; 4$ ounces $15 \mathrm{c}$; pound $40 \mathrm{c}$. WILLET'S IMPROVED WHITE VELVET OKRA-Only listed by us. Has been bred by an Augusta party for some ten years. Now it is one of the earliest okras. Was on the market here at $\mathrm{Au}$. Was on the market here at $\mathrm{Au}$ gusta June 9 th selling at $\$ 1.00$
per peck, one month ahead of any ther okra. Our cut shows sim ply the top of the stalk as cu off. The stalk is usually head high. Each limb carries often 10 plenty of stalks carrying 100 to 125 pods. Cut pods young. Never let them mature,

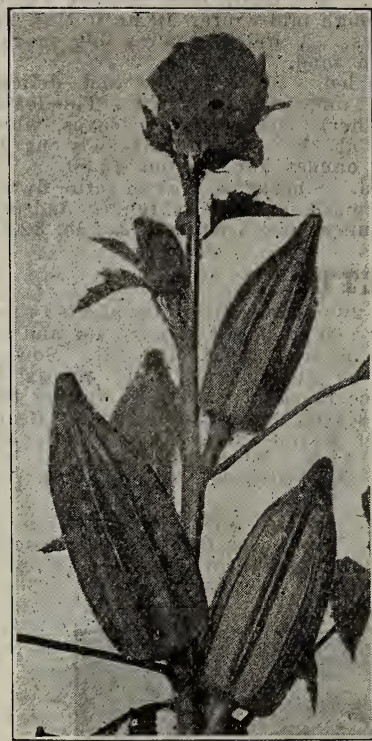
but kep cutting and new okra will keep coming on until frost. This is liest, the most prolific and the finest of all okras on the market. Price, 1 ounce 10c; 4 ounces $30 \mathrm{c}$; pound $75 \mathrm{c}$.

PERKINS IONG PODDED-New, very prolific; pods are intense green in color, of unusual length9 to 10 inches-very slim and do not get hard, as is the case with other okras. Height, 5 to 6 feet. Packet $5 \mathrm{c} ; 2$ ounces $10 \mathrm{c} ; 4$ ounces $15 \mathrm{c}$; pound $40 \mathrm{c}$.

NEW DWARF GREEN PROLIFIC - Early and will bear till frost. Height about 4 feet. Packet 5c; 2 ounces $10 \mathrm{c} ; 4$ ounces $15 \mathrm{c}$; pound $40 \mathrm{c}$.

Culture- Large Onions From Seed - To grow large Onions from seed Willet's Improved White Velvet uary or February in hotOkra. beds, and as soon as the weather opens and sets are size of a goose quill, transplant to rows 12 inches apart and 4 to 6 inches between the onions. Transplanting is of decided benefit. Can also be sown in open ground in February or March, and will make a good crop. The Italian, Spanish and Bermuda varieties can be sown in Aust Septomber September, and transplanted about the end of October or arly in Nove. March or early in April, 40 to 50 pounds an acre, and keep clean of weeds. In late summer, or whenever the tops die, remove the small bulbs, buttons, or sets, to a dry place, spreading them out thinly on trays made of laths, piling the trays one on top of the other, separated by blocks, so that the air can circulate freely. The larger sets should be sold for pickling, and only the smallest retained for planting.

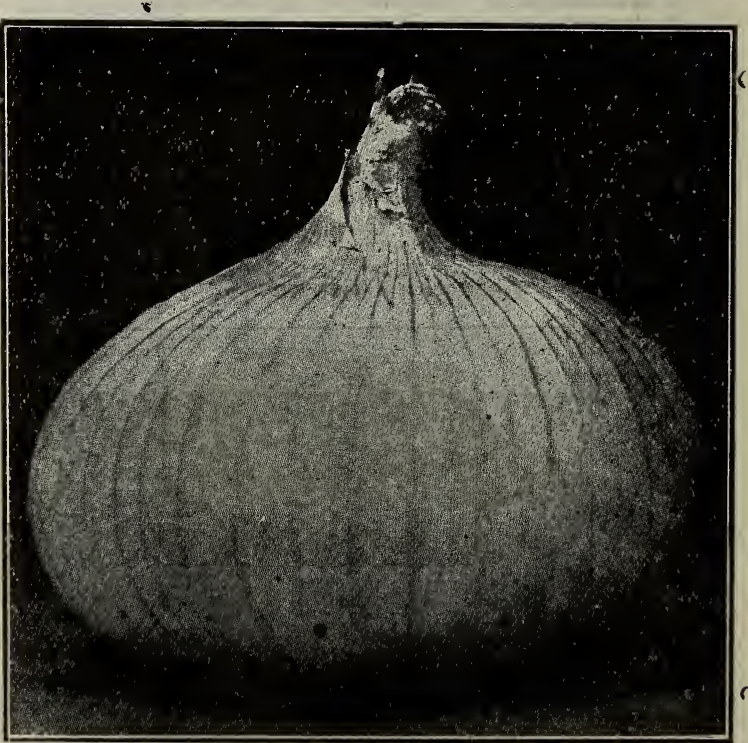

Silver Skin Onion.

WHITE SIIVERSKIN-Flavor mild and pleasant; skin silvery white, of handsome appearance. Extensively planted for white onion sets. Packet $5 \mathrm{c}$; ounce $50 \mathrm{c} ; 4$ ounces $\$ 1.50$; pound $\$ 4.00$. 
AUSTRALIAN BROWN-Deep rich brown, egg-shaped. Dug in spring and kept in sheds, will keep in summer and not rot. A most valuable onion for the South on account of its keeping qualities. Packet $5 \mathrm{c}$; ounce $35 \mathrm{c} ; 4$ ounces $\$ 1.00$; pound $\$ 3.00$.

YELLOW GLOBE DANVERS-Skin of a beautiful silver yellow color, flesh white, comparatively mild, well-flavored. Largely planted for yellow sets. Packet 5c; ounce 45c; 4 ounces $\$ 1.25$; pound $\$ 3.25$.

PRIZE TAKER-Large globe-shaped, light yellow skin; keeps well; weighs 2 to 3 pounds. Packet $5 \mathrm{c}$; ounce $50 \mathrm{c}$; 4 ounces $\$ 1.50$; pound $\$ 4.00$.

LARGE RED WEATHERSFIELD-Of a beautiful form, skin deep purplish red, flesh purplish white, and of a very fine grain. Packet $5 \mathrm{c}$; ounce $40 \mathrm{c} ; 4$ ounces $\$ 1.35$; pound $\$ 3.50$.

WHITE PEARL-Delicate; come off earliest of all; ready for market in January; not good keepers. Packet $10 \mathrm{c}$; ounce $50 \mathrm{c} ; 4$ ounces $\$ 1.50$; pound $\$ 4.00$.

BERMUDA VARIETIES-Of a mild and delicate flavor and keep long. They produce full-grown onions from seed the same season. In the South, seed sown in August or September, produce large onions for market for early spring. Second early varieties and later than Pearl, but spring. Second early varieties and later than Pearl, but flattened; about 4 inches in diameter. We import our seed flattened; about 4 inches in diameter. We import our seed
direct from Canary Islands, from best growers. Plant about 5 pounds to an acre, 1 ounce to $100 \mathrm{ft}$. Plant onions in Florida August to January.

WHITE BERMUDA-The standard market variety; has in reality a light yellow color. Packet $5 \mathrm{c}$; ounce $45 \mathrm{c} ; 4$ ounces $\$ 1.25$; pound $\$ 3.25$.

RED BERMUDA-This variety has the same shape, size and mildness as the white; color, pale red. Packet 5c; ounce $45 \mathrm{c} ; 4$ ounces $\$ 1.25$; pound $\$ 3.25$.

CRYSTAL WAX-This is the pure white Bermuda variety, having a splendid waxy appearance. Never fails to create a great sensation wherever grown. Packet $5 \mathrm{c}$; ounce 50 c; 4 ounces $\$ 1.50$; pound $\$ 4.00$.

\section{ONION SETS}

\section{(32 lbs. to bus.)}

If sent by mail, and for postage at the rate of $1 \mathrm{lb}$. for 1 pint.

OUR ONION SETS are grown on the Lakes in Illinois, screened to one-inch mesh, clean, firm and small. The cheap Kentucky sets are trashy, large, watery and heavy in weight-making a heavy loss to buyer. We can buy miscellaneous sets a great deal cheaper but truckers who plant for market would find them very expensive in the plant for market would find them very expensive in the end. We are large dealers in onion sets; where lare
quantities are wanted we can make very close prices.

Onions as a Succession Crop-The Pearl in green bunches can be sold as early as Christmas; Bermudas a little later; ripens first, Bermudas ripen second in order, and Yellow Danvers and White Silver Skin ripen last. A succession onion crop, both for selling in green bunches, and for selling in their ripened state full size, can be had by planting in the fall early, and at the same time, Pearl, Bermudas and Yellow Danvers and White Silver Skin.

Culture-One quart to $40 \mathrm{ft}$. drill; 8 to $10 \mathrm{bus}$. to acre. Sow early in spring or fall 4 ins. in row, $1 / 2$-in. deep-row 12 to 15 ins. apart. In all localities south of $\mathrm{Va}$. or $\mathrm{Ky}$. plant onion sets for big onions in Oct. and Nov., as by early autumn planting there is a gain in size and early maturing. Onions produced by this system can be placed in market long before those grown directly from the seed in market long before those grown directly from the seed; and the highest market price received for early onions war
rants the outlay. Gather for storing when the tops die rants the outlay. Gather for storing when the tops die; to start growing. For Succession, Onions can be followed by cantaloupes June 1 st, and by rape or mustard in September.

YELLOW DANVERS-The popular main crop sort for spring planting. For many generations the Yellow Danvers Onion has been standard. Possibly is more largely planted than any other onion. Carries a good color. Flatshaped, large in size. One of the principal main crop shaped, large in size. One of the principal main crop sorts for sets or large onions. Keeps well and is a most
desirable market or table onion. Pint $15 \mathrm{c}$; quart $25 \mathrm{c}$; peck desirable market or t
$\$ 1.25$; bushel $\$ 4.25$.

RED WEATHERSFIELD-A pretty onion, round, carrying a purplish red color, and is a fairly good keeper. This onion is the standard variety in the Eastern and Western States. Its color makes it quite an attractive matter to the buyer. A quick-growing, dark red sort, desirable for sets or large onions. Uniform in size and shape, close-

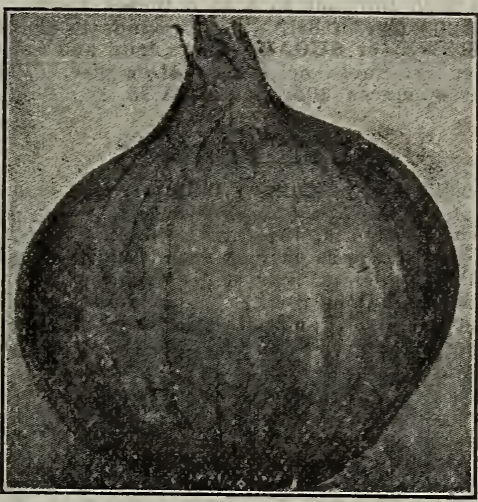

Red Weathersfield Onion. grai $n$ e d, of $\mathrm{m}$ i 1 d flavor. Pint 15c; qt. $25 \mathrm{c} ; \mathrm{pk} \$ 1.25$ bu. $\$ 4.25$.

W H I T E SIIVERSKIN

-The b e s white onions f o $r$ growing from sets in $\mathrm{t} h \mathrm{e}$ spring. $M$ ild flavor, and $l$ a $r$ g $e$ yielders. Their whiteness and tenderness are attractive qual. ities to housekeepers. It makes a good size o $n$ i o $n$
from the sets. All of the little white pick-

ling onions that are bought in the bottles are young white silverskin. Pint 20c; quart 35c; peck $\$ 1.50$; bushel $\$ 5.00$.

WHITE MULTIPLIER-36 lbs. to bushel summer, or 32 lbs. in winter. Plant from August to and through February. Grow like potatoes in a hill; yield enormously; mild flavor; called salad onions. Pint 20c; quart $35 \mathrm{c}$; peck $\$ 1.50$; bushel $\$ 5.00$

BERMUDA AND PEARI ONION SETS-SE Fall Catalog.

\section{PARSLEY}

Culture-For spring seeding sow in February, March or early in April. Soak a few days and then sow in rows a foot apart, and cover about half an inch. Slow to germinate, sometimes two or three weeks in coming up. One ounce will sow 150 feet of drill. Plant parsley in Florida any time.

For fall and winter use, sow in August or September. Fall and winter growing of parsley should prove very profitable for the South, owing to our mild climate. There is always a good sale at a remunerative price, both at home and in the Northern markets during the winter and spring. Ready in 85 to 110 days. For Succession Parsley can be followed May 1st by collards or beans; July 15th by sweet potato cuttings.

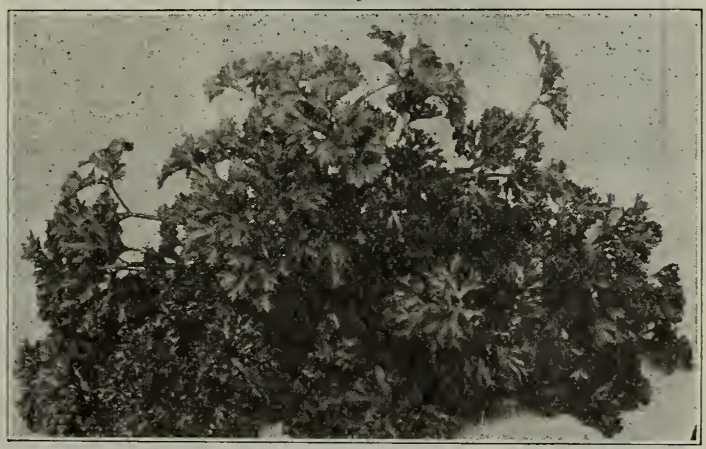

Moss Curled Parsley.

CHAMPION MOSS CURLED-The best and most improved strain. Beautifully curled and crimped, and is the best for garnishing and flavoring. Makes an ornamental plant for edging walks. Packet $5 \mathrm{c}$; ounce $10 \mathrm{c} ; 4$ ounces 30c: pound $\$ 1.00$.

PLAIN, or SINGLE-Very hardy, and stronger in flavor than the curled. Packet $5 \mathrm{c}$; ounce $10 \mathrm{c} ; 4$ ounces $25 \mathrm{c}$; pound $85 \mathrm{c}$.

\section{PARSNIP}

A most useful winter vegetable. The roots can remain in ground and be dug as wanted, or can be stored for use. Their nutritive and medicinal qualities are first-class, and they come in at a time when other vegetables are scarce. Should be largely grown, both by private gardeners, truckers and dairymen. Germinate in about 14 days. Better soak 24 hours. Ready in 120 to 160 days. Market August 20th to January. Plant August to April. 
Culture-A rich, sandy loam, deeply worked, is the best. Sow in spring, in drills 18 inches apart covering lightly. When 2 inches high thin out to 4 or 6 incbes apart. One ounce will sow 200 feet of drill. Five pounds to the acre. HOLLOW CROWN, or SUGAR-Roots long and smooth. The best either for table or stock-feeding use. Packet $5 \mathrm{c}$; ounce $20 \mathrm{c} ; 4$ ounces $60 \mathrm{c}$; pound $\$ 1.75$.

\section{GARDEN PEAS}

Culture-Inoculate with Mulford Cultures-for legumes; $1-8$ acre $25 \mathrm{c} ; 1-4$ acre $50 \mathrm{c}$. Peas succeed best in light rich, loamy soil, manured the previous season. Plant smooth varieties in spring as soon as ground can be worked, in rows 3 to 4 feet apart, 2 inches deep, giving taller va rieties more room between rows. The wrinkled varieties are tender and should be planted later than the smooth. For a succession, plant every two weeks. The dwarf varieties can be planted in rows $2 \frac{1 / 2}{2}$ to 3 . feet apart. Peas grown as a market crop are rarely ever staked. But when taller varieties are grown for private use, it is a good plan to sow them in double rows and stake with brush. Should be kept clean and the earth worked toward them two or three times during the growth. Plant January to Augustusually . February 10th, also September. Ready in 50 to 90 days. Yield about 100 bushels per acre. Market April 25 th to August. One and a half bushels plant an acre one quart plants 100 feet of drill. For Succession English Peas can be followed by bush beans, May to June, and by turnips or rutabagas in July and August; in October by beets and onion sets.

If to be sent by mail, add for postage at the rate of 1 pound for 1 pint. Packets mailed free. Plant in Florida September to March.

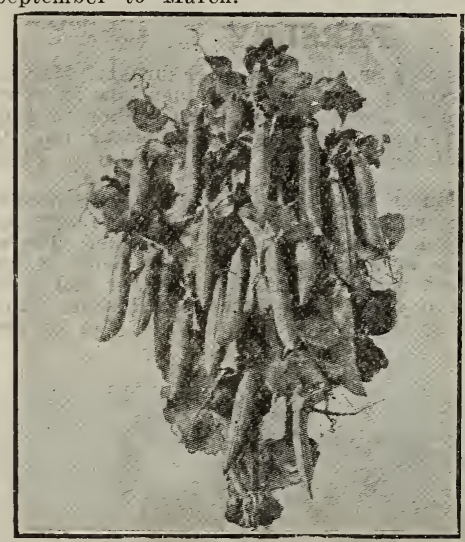

FIRST AND BEST, or PHIL ADELPHIA EXTRA EARLY Perhaps the earliest pea cultivated; produc tive and well flavored. Productive a $\mathrm{n}$ hardy, with strong, vigorous vine, which is light in color and uniform in growth. $P$ o d s straight, 2 1-2 inches 1 o $n \mathrm{~g}$ $\mathrm{r}$ o u $\mathrm{n} \mathrm{d}$, light green in color and blunt. See light cream color, round, and slightly dented. First and Best Peas. Height of straw Packet $5 \mathrm{c}$ and $10 \mathrm{c}$; pint $30 \mathrm{c}$; quart $50 \mathrm{c}$; half inches. Pack $\$ 3.00$; 100 ; pint $\$ 100$

peck $\$ 1.75$; peck $\$ 3.00$; bushel $\$ 10.00$.
ALASKA-Standard and the earliest of all the blue peas, proving to be not only several days earlier than most early sorts, but of a large size, and 10 per cent more productive. Popular with early market gardeners. Foliage light green, pods $2 \frac{1}{2}$ inches, straight, round, and retain fresh green color after picking. Seed medium small, slightly dented. Height 31 inches. Packet $5 \mathrm{c}$ and $10 \mathrm{c}$; pint $35 \mathrm{c}$; quart $60 \mathrm{c}$ half peck $\$ 2.00$; peck $\$ 3.50$; bushel $\$ 12.00$.

TELEPHONE-One of the most productive of the wrinkled sort. Of excellent sugary flavor pods large, containing 6 or 7 peas each. Rather late in maturing, but one of the best for main crop. Height 4 feet. The juicy sweet peas you eat in a can are apt to be Telephone. Packet $5 \mathrm{c}$ and $10 \mathrm{c}$; pint $35 \mathrm{c}$; quart $60 \mathrm{c}$; half peck $\$ 2.00$; peck $\$ 3.50$; bushel $\$ 12.00$.

AMEER-Called by some Mammoth Large Pod Alaska. Now used largely on the Carolina Coast. Pods longer and pea larger than Alaska and a trifle more dented, and bluish green color. Height 30 inches, pods 3 inches long. Pkt. 5c and $10 \mathrm{c}$; pt. $35 \mathrm{c}$; qt. $60 \mathrm{c} ; 1 / 2$ pk. $\$ 2.00 ; \mathrm{pk}$. $\$ 3.50 ;$ bu. $\$ 12$

GRADUS-A large wrinkled early pea with a pod nearly as large as Telephone, with large peas, tender, of good quality and flavor. Quick to germinate, maturing with the earliest sorts and with quick, warm, rich and favorable conditions, a good cropper. Foliage large and luxuriant, pale green. Pods 4 inches long slightly rounded at the point. Seed large wrinkled, cream color tinged with green Height of straw' 36 inches. Luscious peas, 8 to 10 or more in a pod. The peas are of the highest table quality. Packet $5 \mathrm{c}$ and $10 \mathrm{c}$; pint $40 \mathrm{c}$; quart $75 \mathrm{c}$; half peck $\$ 2.50$; peck $\$ 4.00$; bushel $\$ 13.50$.

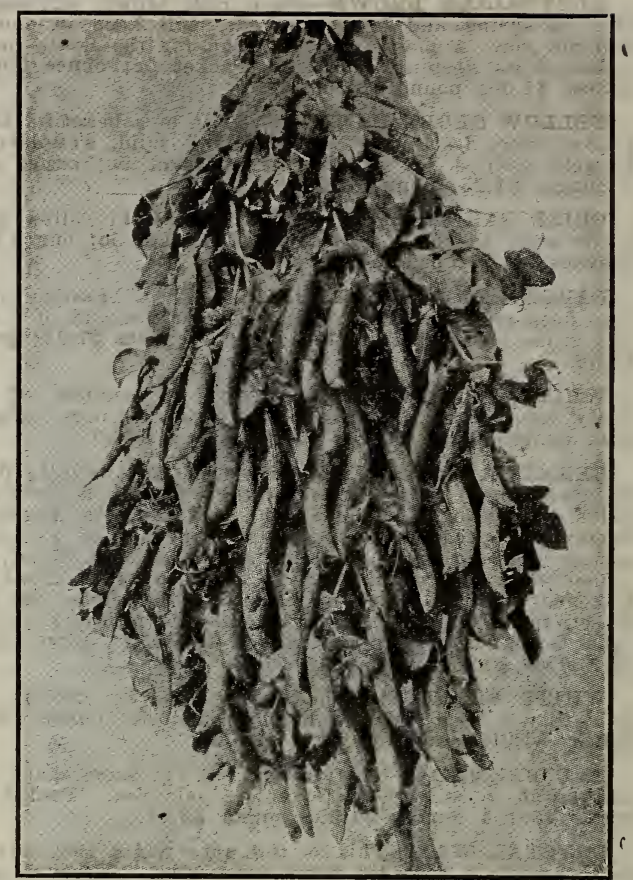

Gradus Pea.

SUTTON'S EXCELSIOR-The finest dwarf pea in cultivation, for private and market gardeners. A dwarf wrinkled pea in the front rank for earliness, with much larger and handsomer pods than any other variety in this class. Takes the place in $t \mathrm{~h}$ e Dwarf class filled by Stratagem a $\mathrm{n} \mathrm{d}$ Telephone in later sorts, and by Gradus and Laxtonian in the early class. Vine rugged and strong and require no support. An abundant cropper, frequently producing pods in pairs. pods in pairs. long, $b \mathrm{r}$ o a d straight, well filled to the end Seed pale green, wrinkled, medium large. Height of straw 15 inches.

Packet $5 \mathrm{c}$ and $10 \mathrm{c}$; pint 50c; quart pint 50c; quart 90c; half peck $\$ 3.00 ;$; ok.

CHAMPION OF E NGIA N DMuch prized by Much prized by those who are tender and lus eious pea. Hardy and vigorous in

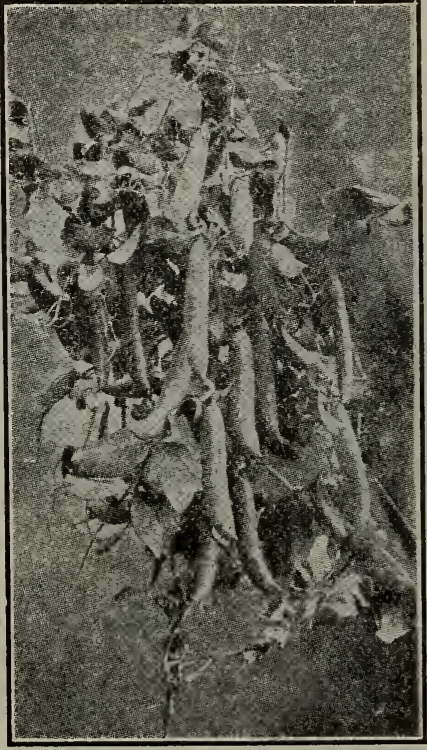

Sutton's Excelsior. growth, fol i a ge 3 inches long, blunt, medium dark green in color, broad and nearly straight. Seed light green very much wrinkled. Sow thick. Packet 5c and 10c preen, $30 \mathrm{c}$; quart $50 \mathrm{c}$; half peck $\$ 1.75$; peck $\$ 3.00$; bushel $\$ 100$. McLEAN'S PREMIUM GEM-Early dwarf; $11 \frac{1}{1 / 2}$ feet high; wrinkled pea; prime favorite. Packet 5c and 10c: pint $35 \mathrm{c}$; quart $60 \mathrm{c}$; half peck $\$ 2.00$; peck $\$ 3.50$; bushe $\$ 12.00$.

LARGE WHITE MARROWFAT-Vines hardy, vigorous. bearing leathery pods near the top Resembling in habit and appearance the Black-Eye Marrowfat. Foliage light green. Pods 3 inches long, blunt and of light green color. 
Seed large, smooth, white and slightly oval. Not especially sweet nor juicy. Height of sraw 48 inches. Main or late crop. Packet $5 \mathrm{c}$ and $10 \mathrm{c}$; pint $25 \mathrm{c}$; quart $45 \mathrm{c}$; half peck $\$ 1.50$; peck $\$ 2.75$; bushel $\$ 9.00$

BLACK-EYED MARROWFAT-Hardy, strong and vig orous, bearing broad, thick leathery pods, 3 inches long, near the top of the vines containing four or five large peas of indifferent quality for the table and but little used for that purpose since the introduction of the more desirable wrinkled varieties. Seed large round, white, with a distinct black eye; not especially sweet nor juicy. Height of straw 48 inches. Packet $5 \mathrm{c}$ and $10 \mathrm{c}$; bulk price same as White Marrowfat.

\section{Pepper}

Culture-Same culture as Egg Plant, sowing in hotbed in February or March and transpanting outside in May, 15 inches apart, in 2 or 3 -foot rows. When ground becomes warm, sow outside and transplant as above. Cultivate well. when the plants are 6 inches high, will materially increase the yield. One ounce will produce about 1,000 plants. Ready in 95 to 130 days. Market June 1 st to October 10 th. Plant peppers in Florida September to J Inuary.

SWEET GOLDEN DAWN, GOLDEN BELL OR QUEEN -Bell-shaped, mild flavor, golden yellow. Packet 10c; ounce $75 \mathrm{c} ; 4$ ounces $\$ 2.00$; pound $\$ 6.00$.

BULI NOSE, or SPANISH MONSTROUS-A favorite for pickling or for mangoes; rind thick and fleshy. Packet $10 \mathrm{c}$; ounce $75 \mathrm{c} ; 4$ ounces $\$ 2.00$; pound $\$ 6.00$.

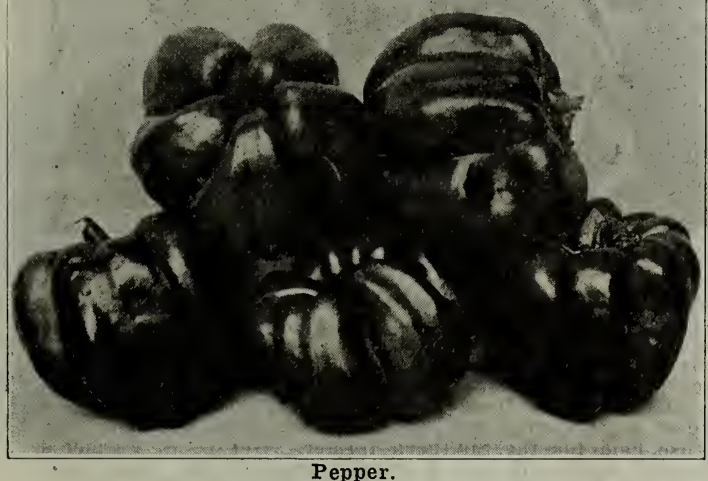

PERFECTION PIMENTO-The only canning pepper for making "pimento." Agricultural Department at Washington says that "Perfection" is the best of all "pimento" peppers. Slips skin when heated. Big size. Thick meat. Meat three times thick er than Bell Peppers, more edible product. Few seeds. Sweet flavor like an apple. The mildest of all peppers and sweet and percious. Smooth. Scarlet when ripe: yields let when ripe; yields until frost. Packet $10 \mathrm{c}$; ounce $35 \mathrm{c} ; 4$
$\$ 1.00 ; 1$

CHINESE GIANTEnormous size, thick, fleshy, form glassy scarlet. About 4 inche broad, 4 or 5 deep fruit sets in clusters, flesh tastes mild like apples. Slice, serve like tomatoes. Very few seed-hence high price of seed. Sometimes they are 14 ins. around. Packet $10 \mathrm{c}$ ounce $85 \mathrm{c} ; 4$ ounce $\$ 2.25$; pound $\$ 7.00$.

RUBY KING-Popular, large red pepper. Plants grow several feet high and bear fine crop of extra large crop of extra large scarlet fruits. sweet, and so mild that the peppers may

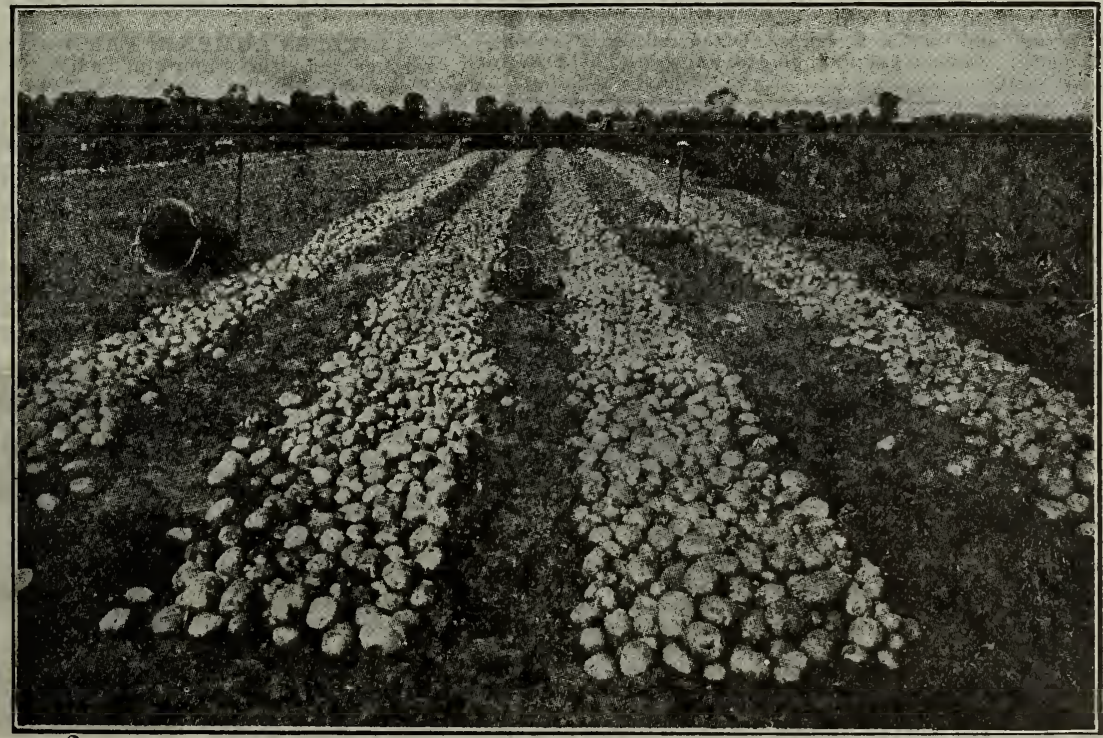

Field of Irish Cobbler Potatoes. be eaten like an apple; fine for mangoes. Packet $10 \mathrm{c}$; ounce $75 \mathrm{c} ; 4$ ounces $\$ 2.00$; pound $\$ 6.00$.

LONG RED CAYENNE-Small, long tapering, very hot fine for seasoning. Packet $10 \mathrm{c}$; ounce $50 \mathrm{c} ; 4$ ounces $\$ 1.50$; pound $\$ 4.50$.

PEPPER PLANTS-Note: Pepper, plants, in small amounts by mail, Chinese Giant, Ruby King, Large Bell,
Pimento shipments from April to June. CASH WITH ORDER, 40c per dozen, postpaid; 3 dozen for $\$ 1.10$ postpaid.

\section{Irish Potatoes}

IRISH POTATOES-Ten bushels per acre, or 1 peck to 125 hills in drills 3 feet apart; 3 or 4 cuttings to one potato. Plant from February 1 st to tApril 1 st. Produce 90 to 200 bushels per acre, maturing in 105 days-May 25 th to June 5 th. One sack holds ten pecks.

Our Seed Potatoes are all specially grown for seed purposes in the best potato districts in this country.

We do a large business in seed potatoes, our trade every year experiencing a constant and steady growth, resulting from the fact that our seed potatoes have acquired the very best reputation for quality, productiveness and satisfactory

Culture of Potatoes-Potatoes are usually planted in rows 3 feet apart, and the cut-pieces one foot apart in the row. Cut two eyes to the piece. Do not use stable manure on Irish potatoes. Irish potatoes, turnips and oats follow each other well.

For Succession Irish potatoes can be followed by watermelons, about June $1 \mathrm{st}$, and by spinach, turnips and winter radishes in October.

Prices of Potatoes Fluctuate-Crops are short this year, and prices are high.

"PRACTICAL POTATO CULTURE',-Is a 128-page book written by E. A. Rogers, giving in detail the State of Maine methods for growing potatoes where the average yield per acre is the largest of any state in the Union. There are 25 cuts of types of potatoes, together with illustrations showing the various methods, from preparing the soil to harvesting, storing, shipping. Price $50 \mathrm{c}$ parcel post.

Potato Diseases. For blight spray with Bordeaux Mixture. For Potato Bug-See Insecticide page. Irish Potato Scab-To one pint formalin add 35 gals. water in a bbl. Soak potatoes as held in a bag $11 / 2$ hours. Potatoes by bag 150 lbs. Bushel 60 lbs. Peck 15 lbs.

\section{Maine Grown Potatoes.}

IRISH COBBLER-We have never sold a variety of potatoes of which we have received more uniformly satisfactory and enthusiastic reports from our customers, and we recommend it strongly as a most desirable and productive extra early variety of excellent tab duces smooth, round, plump and handsome

The tubers are a beautiful creamy white, eyes strong, well developed and slightly indented which in potatoes always rop results. or market ten or twelve days earlier than Early Rose. 
proves a distinctive mark of fine quality. This potato is by far the most popular potato today in America for the trucker not only because it is productive but because the white Irish potato is twice as easily sold on the market as a Bliss potato th

HOULTON EARLY ROSE-The Rose still continues one of the most popular varieties, in our list. Productive, of most excellent table qualities, and a satisfactory all-around early variety. The Northern-grown stocks which we offer this variety. Peck $\$ 1.00 ;$ bushel $\$ 3.50 ; 10$-peck sack $\$ 7.00$.

EARLY RED BLISS TRIUMPH-An extra early potato, round in shape, pink skin, white flesh, and of handsome appearance. This seems to be specially adapted to Southern soil and climate, and is a great favorite with Southern truckers. Is also largely grown for second crop, and sold in Northern markets for New Bermuda Potatoes during the
late winter and early spring. Peck $\$ 1.35 ;$ bushel $\$ 4.25$; 10 -peck sack $\$ 8.00$.

WHITE BLISS-A variety similar to the Red Bliss in shape, but having a white skin. A very popular and productive early variety. Pk. $\$ 1.00$; bushel $\$ 3.50 ; 10$-peck sack $\$ 7.00$.

GREEN MOUNTAIN-A large handsome oval white potato. Medium late. One of the finest eating potatoes known to the trade. Shallow-eyed, fine texture, well flavored and a most prolific yielder. It is not susceptive to dis eases, and is fast becoming the standard white potato for late planting in 10 -peck sack $\$ 7.00$.

\section{SECOND CROP POTATOES.}

Second crops are gathered in fall from Southern summer plantings, and kept over for spring plantings, and sold in competition with Northern seed potatoes. Are equal in every way to Northern seed. Keep longer in spring before they sprout; and are the best potatoes for putting on cold storage in spring for late summer plantings.

EARLY RED BLISS, or TRIUMPH-Peck $\$ 1.35$; bushel $\$ 4.25 ; 10$-peck sack $\$ 8.00$

IRISH COBBLER-Peck $\$ 1.00$; bushel $\$ 3.50 ; 10$-peck sack $\$ 7.00$. $\$ 7.00$.

\section{Irish Potatoes-Summer Planting.}

LOOKOUT MOUNTAIN POTATOES-A distinctive type potato and sown only in summer for fall crop. Make orders early in season; deliveries between June 1 st and July 15 th, not later-cash with order. Tubers often weigh 2 pounds. Harvest about November 1st. Potatoes will keep in ground all winter. If kept properly in the barn there is often no shrinkage to June 1st-motatoes sound there is often no shrinkage to June 1st-motatoes sound
and unshrunken. The only sure fall crop; never fails to come up and make a crop. Often make 200 bush els per acre. Easiest keeping potato known. The best for fall and winter market. Always have sprouts on them in July, and this insures their coming up. To keep Looko u t Mountain potatoes, put potatoes in a dry room, 3 to 6 platform, shelves or $s$ h a 1 l o w boxes, or bank $\mathbf{R}$ e a d same $\underset{\text { "culture", as to }}{\mathbf{e} \text { a d , same }}$ other Irish potatoes. Bugs do not trouble this fall crop.

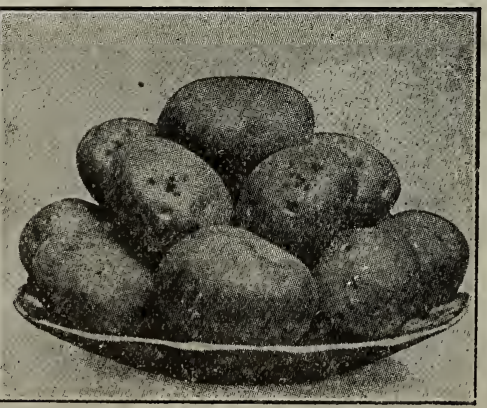

Selected Second Crop Seed Potatoes.
Keep in the dark all the time. Keep perfect for the table, from November 15th to May 15th, and then spur just in time to plant-more than eight months. No other Southern-grown potato will do this. Best on red clay land. Good money crop. We have three or four growers each who make 1,000 bushels. Never plant before June 10th. Lookouts are never put on cold storage.

Potatoes by Weight.-We quote and sell Lookouts by weight. Bag, $137 \frac{1 / 2}{2}$ lbs. Bushel, 55 lbs. Peck, $13 \frac{3}{4} \mathrm{lbs}$. Deliveries made between June 1st and July 15th, not later. Peck $\$ 1.50$; bushel $\$ 4.50$.

\section{Sweet Potatoes}

Sweet Potato Culture-We set out draws here in March, April and May, and set out vine cuttings June and July8,000 per acre. Usually rows are 4 feet apart and plants are 18 inches in drill. Average yield in United States per acre 94.5 bushels. Standard weight spring 55 pounds per bushel. Are frequently planted in the fall in Florida, mature in spring, and the crop is thus sold throughout the year.

For bedding use small potatoes whole; cut the large ones n half and bed with the eyes up.

Yield, 175 to 200 bushels per acre; 200 pounds Acid Phosphate is a good fertilizer. Do not use nitrate of soda.

We begin digging July, and our truckers sell out their full crop. We take vine cuttings and reset them in the same ground, and get grown potatoes in October. We have planted from the vine as late as August 22d, and 
ductive and improves with keeping. Leaf pointed. When parboiled and then sliced, baked with some sugar, it makes one of the richest-looking dishes ever put upon the table.' This potato is a trifle late. Sometimes cooks hard. Bag, 2 bushels for $\$ 4.50$.

EARLY TRIUMPH-Very early; canners favorite. Flesh light yellow, oblong, very prolific, earlier than the late potato Very large. potato. Smooth skin. Cr soft. Enormously productive a $\mathrm{n} d$
keeps late. Somewhat more mealy and dry than some potatoes. Vines short, dense, vigorous. The leaf is pointed and indented; veins in leaves are purple; good keeper; often weigh 3 lbs. We have dug them here 20 th of June as set out

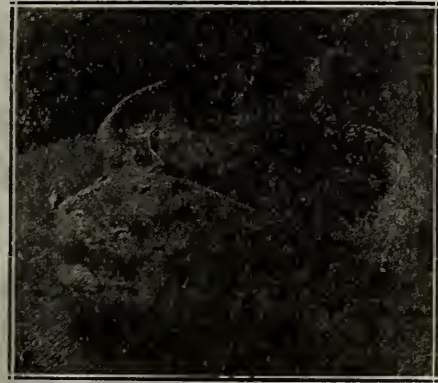

Early Triumph Sweet Potatoes. have set out from the vines on August $22 \mathrm{~d}$ and made good potatoes October 1 st. $\mathrm{Bag}, 2$ bushels, for $\$ 4.50$.

PORTO RICO YAM-Known, too, as Golden Beauty and New Providence. Around Norfolk a sensational potato;

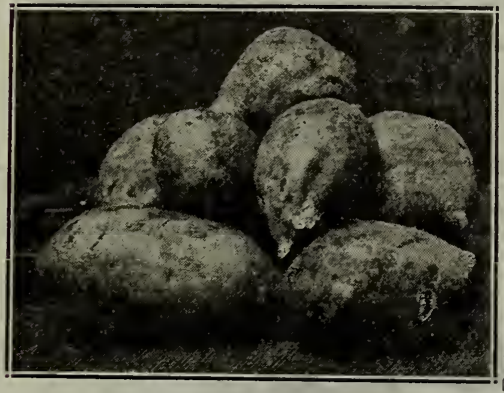

Porto Rico Sweet Potatoes. yellow fl e s h pink skin; fine quality; sprouts earlier $\mathrm{t} h$ a $\mathrm{n}$ $\checkmark$ a n c y Hall mature quickly very productive. G r o w quicker and larger than same color as Sumpkin. This superior potato now is sold in in place of the Pumpkin Yam. $F$ i n e keeper. Exp. Sta. rels per acre. Cooks always soft. In ports 277 bushels per acre. Cooks always soft. In Florida this is the leading potato, and has largely succeded Nancies and
other types. Unlike other potatoes the new early potatoes are delicious and sweet. This is also a fine keeper. The potatoes now in greatest demand are the Porto Rico and Nancy Hall. Bag, 2 bushels, $\$ 4.50$.

NANCY HALI-Known also as Providence, also Norton. Almost a bunch potato, easily cultivated; leaf pointed; color is reddish, skin is reddish, stem ditto. Late July planting from vines make good, large potatoes; elliptical like a beet in shape; a poor land potato. Round, smooth, very early-60 days after planting. Very good for table. Productive, good keeper. Grower says: "I plant $31 / 2$ feet rows and 14 inches in row. I made 200 bushels per acre Nancy Hall-yellow as gold, cook soft and sweet-good keepers." Experienced growers pronounce this potato as being the most delicious eating potato known. Sprouts or draws are more numerous and tougher than other kinds. The Georgia Experimental Station reports 200 bushels per

TRUCKERS' EARLY PROLIFIC-In size as large as Triumph. Carries a few small potatoes. Purplish vines. Eats soft. Color inside like Porto Rico; almost as deep as Pumpkin Yam. Vines short. Three weeks earlier than Pumpkin Yam. Makes two crops easily. Eats well and is our best keeper. This potato has pink skin like Nancy Hall outside. Planted here July 15,1916 , made potatoes weighing 2 pounds fully developed the whole crop making 140 bushels to the acre. The writer regards this potato as the best " "eater" or too dry. It has a distinctly individual flavor and differs from other potatoes, and is extremely palatable. Price: We sell only draws. See below.

WILLET'S EARLY RED SKIN or RED BERMUDA(Not the old Negro killer.) - Our experience covering about ten years is that this potato is the earliest of all potatoes in the fields. The beds themselves come off in the matter of draws earliest of all and make far more draws than other beds. With cut vines in August you can make big potatoes. A juicy yellow meat; smooth yam. More prolific than even Pumpkin Yam, and 25 per cent to one-third larger. Very early-makes good "eating" in June; the market-man's friend. Elliptical; very few small ones. Largely used by truckers about Charleston, who "get two crops a season. A fine eater. Called on coast "Peabody." We market here in July, and replant vines. Fine keepers; cipal Atlantic City Hotel potato in August. We sell only draws. See Potato Draws below.

GEORGIA SUGAR YAMS-The old-fashioned kind; not prolific, making only 60 to 75 bushels per acre, but the sweetest of all potatoes for home use. Tubers are medium size, oblong, light in color, cook soft and yellowish; leaves are forked with 4 or 5 slits; long vines; earlier than Pumpkin Yams, but later than early varieties. We sell only draws. See Potato Draws below.

YELLOW JERSEY RUNNING POTATO-A new potato; not akin to the "White Jersey," but superior to it. Russet color on the outside and canary yellow on the inside. Flavor is delicate, a good eater, but not so juicy as red yams. Flesh is fine-grained and not tough or stringy or fibrous. Shape is elongated-fine for baking. One hill produced last year 200 potatoes-from 2 ounces up to 2 pounds.

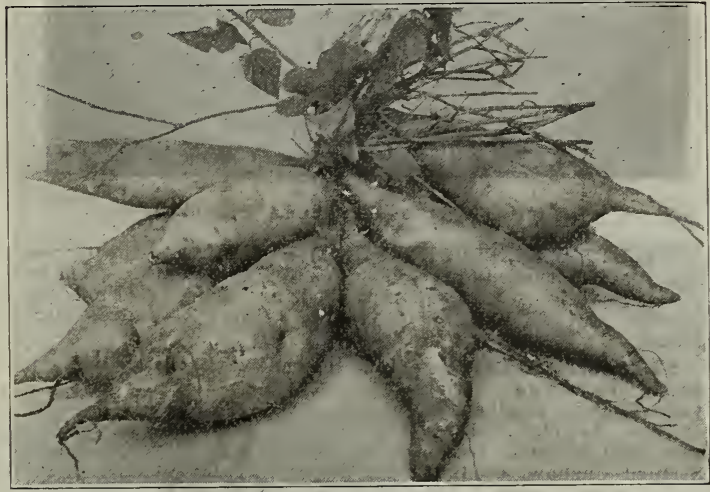

Yellow Jersey Running Potato.

They bear or produce literally all over the ground. Cultivate on the level. From each joint of the vines a root takes place which bears potatoes-not as large as other potatoes. The most prolific of all potatoes. For eating purposes this potato is liked by many better than the red juicy yams. Especially indicated in the South as a hog feed for hogging. One acre of them will produce more in root crops than any other known root crop. The hog man must get in the use of it. Draws only sold-Augusta draws.

\section{DRAWS}

FLORIDA EXTRA EARLY POTATO DRAWS-See CuIture previous page. Nancy Hall, Porto Rico, TriumphWe list the above f. o. b. Florida. Delivery according to season. March and April. $1,000 \$ 2.25 ; 5000$ to 10,000 $\$ 2.00$ per $M$ f. o. b. Florida, cash with order.

SWEET POTATO DRAWS, or SPROUTS, F. O. B. AUGUSTA-See Culture previous page. All varieties listed above. Send orders early. Entry of orders is in seriatim. Demand is usually more than supply. Shipments from $\mathrm{Au}$ gusta are usually in May and through eary June (See above for Florida early Draws). No orders booked except for cash. When you receive your plants dip roots in water until they are fully revived (do not wet the tops). Plenty of water to the roots in planting means success. Price. by Express, 1,000 to $2,000 \$ 2.00 ; 3,000$ at $\$ 1.85 ; 5,000$ to $10.000 \$ 1.75$ per $\mathrm{M}$.

SWEET POTATO CUTTINGS-We ship these cuttings 12 to 14 inches long usually in June or July, both from Augusta and Florida, by express. Types: Pumpkin Yam, Porto Rico and Nancy Hall. Cuttings usually make 25 bushels more per acre planted in June than draws, and just as big ones. For late potatoes, cuttings are best. Price, 1,000 to 2,000 at $\$ 1.75$ per thousand; 3,000 at $\$ 1.65$; 5,000 to 10,000 at $\$ 1.50$ per thousand, cash with order.

\section{PUMPKIN}

Culture-Plant April 15th to June in hills 8 to 10 feet apart, mixing well-rotted manure in each hill, 5 or 6 seeds in each hill, and cultivate till vines get strong, when they should be thinned out, leaving 2 or 3 in each hill. When planted in corn, plant at the same time as the corn, in every fourth row, 10 to 12 feet apart in the rows. Do not grow near squashes or melons. Keep off bugs by dusting with Slug Shot, Paris Green, on land plaster. One ounce will plant 20 hills; 3 lbs. one acre. Valuable, easily grown For human or cattle food. Eaten green, too, like squashes. 
WILLET'S KING OF MAMMOTH PUMPKIN-The best grower of it in America says: "It is extra vigorous ; shape oblong; fine orange color; size as large as 60 to 80 pounds; a good shipper; fine for pies and sauce, and gives good results to vegetable and market gardeners, and equally as good results to the farmer; a truly magnificent type of pumpkin." Price, 4 ounces $35 \mathrm{c}$; pound $\$ 1.00$.

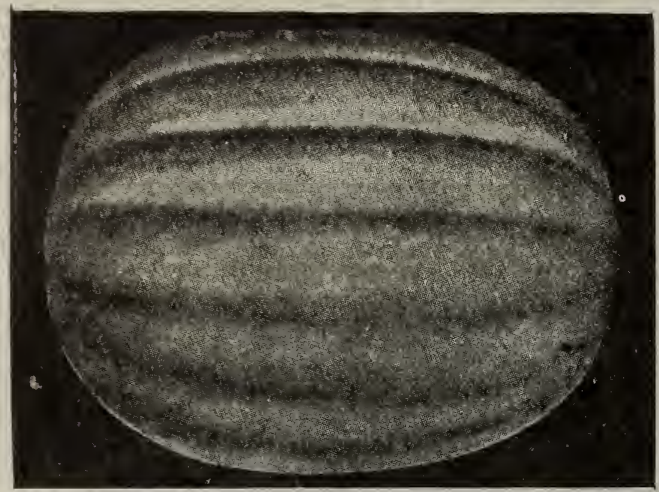

Willet's King of Mammoth Pumpkin.

WILLET'S KENTUCKY FIELD PUMPKIN-One of the best and most productive varieties for the South. Can be kept all through winter and used as desired. Fine for table or stock. Flesh a rich golden yellow. 4 ounces $20 \mathrm{c}$; pound $50 \mathrm{c}$.

STRIPED CUSHAW-Skin striped with mottled green bands of white. Rich yellow meat, tender and of fine flavor. This is the old-fashioned Green Striped Cushaw, crooked neck, very prolific; the best keeper and undoubtedly the finest table sort known for fall and win ter use We grew on in 1918 weighing 30 one in 1918 weighing 30 lbs. $40 \mathrm{c}$; pound $\$ 1.25$.

SEMINOLE PUMPKIN-Known well in Florida. Hardy, wildgrowing; grows on the ground or up a treethe Seminole Indians in Florida grow it on trees and cut the stems from off the fruit with their rifle balls. The vines take root at their joints -one vine thus covering a big space. My grower reports one vine spread- Striped Cushaw.
ing 50 feet, and making 134 pumpkins; from one acre he gathered 25 wagon loads. Average 2 pounds in weight color light yellow to gray. Plant up to June 15th. Make fine human and hog and chicken food. Keeps sound for a year-and six months in the open field. Shell is hard: split with a hatchet. Bake like a potato, or remove and cook the inside matter and then serve on the half-shell. Plant in cornfields, or in the open, $10 \times 10 \mathrm{ft}$., two seeds. Taste is between squash and pumpkin. Small secd. Price: 1 ounce $30 \mathrm{c} ; 4$ ounces $\$ 1.00 ; 1 \mathrm{lb}$. $\$ 3.50$.

\section{RADISHES.}

Culture-Plant February 1st to May; August to October. Ready in 25 to 40 days. Market April to June 15th, and September 15 th to December 15 th. To be tender and crisp, must be grown quickly. Commencing with the first mild spell in the spring, sow at intervals of ten days, in light, rich, deeply-worked soil. May also be sown as a catch crop between rows of beets, lettuce, onions, etc. Can be forced in hotbeds but must have plenty of rentilation and moisture. For fall and winter use, sow Rose China winter or the Spanish varieties in August or September. One ounce will sow 50 feet; 8 to $10 \mathrm{lbs}$. one acre. Many people cook the tops and roots together. For Succession Radishes can be followed by pepper or tomato palnts about April 1st, and by lettuce in September. Plant radishes in Florida any time.

EXTRA EARLY SCARLET TURNIP-One of the earliest radishes and one of the best for forcing. Makes a very small top of bright red color, and is very attractive, both in color and shape, making it a good seller. Mild, crisp, juicy and tender. Packet $5 \mathrm{c}$; ounce $15 \mathrm{c} ; 4$ ounces $40 \mathrm{c}$; pound $\$ 1.10$,

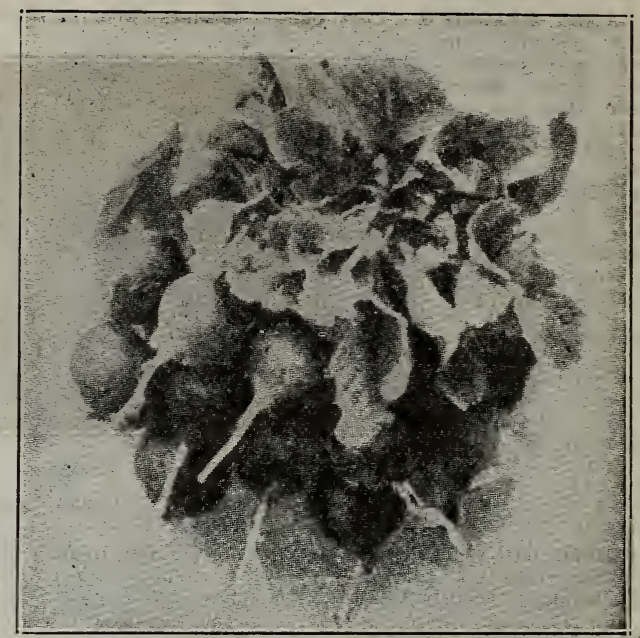

Early Scarlet Turnip Radish.

HALF-LONG SCARLET RADISH-A half-long, fine radish, well known. Packet $5 \mathrm{c}$; ounce $15 \mathrm{c} ; 4$ ounces $40 \mathrm{c}$; pound $\$ 1.10$.

LONG SCARLET SHORT TOP-A beautiful long radish, of a deep crimson, shading to white at the tip. Splendid for outdoor culture. Will keep tender longer than any other variety. Packet $5 \mathrm{c}$; ounce $15 \mathrm{c} ; 4$ ounces $40 \mathrm{c}$; pound $\$ 1.10$.

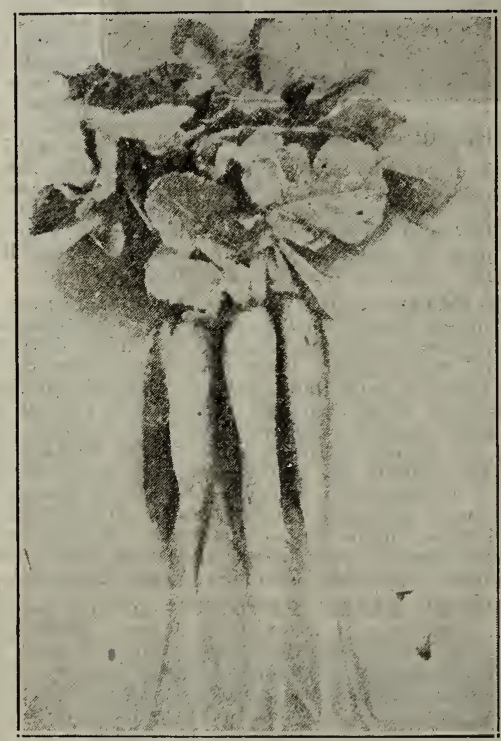

Long Scarlet Short Top.

FRENCH BREAKFAST-Of quick growth; crisp and tender. Color scarlet, except at tip, where it is pure white. Packet $5 \mathrm{c}$; ounce $15 \mathrm{c} ; 4$ ounces $40 \mathrm{c}$; pound $\$ 1.10$.

CHINESE ROSE WINTER-Best fall and winter variety. Packet $5 \mathrm{c}$; ounce $15 \mathrm{c} ; 4$ ounces $40 \mathrm{c}$; pound $\$ 1.10$.

IONG BLACK SPANISH-One of the latest as well as hardiest of radishes, an excellent sort for winter, oblong. black and flesh of firm texture. Packet $5 \mathrm{c}$; ounce $15 \mathrm{c}$; 4 ounces $40 \mathrm{c}$; pound $\$ 1.10$.

SCARLET TURNIP WHITE-TIPPED-An attractive short variety; globe-shaped; bright rose carmine; with bot- 
tom and tip clear white and leaves small. Packet 5c; ounce $15 \mathrm{c} ; 4$ ounces $45 \mathrm{c}$; pound $\$ 1.20$.

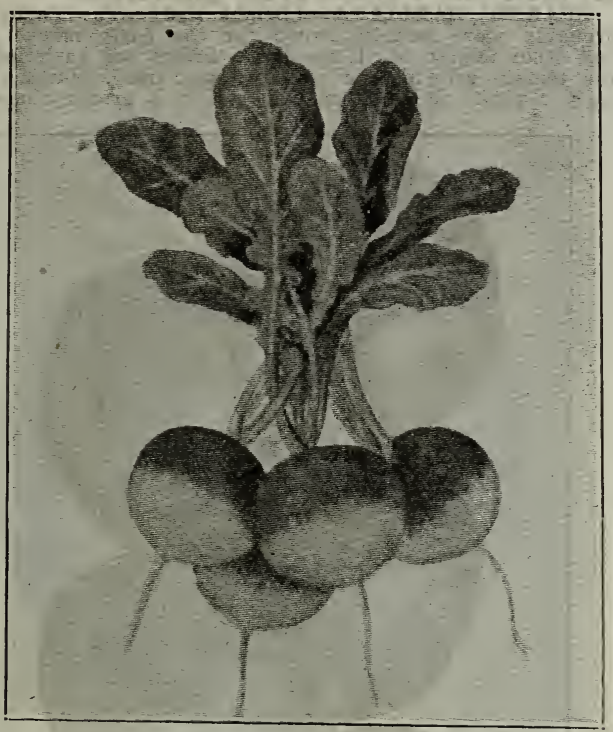

Scarlet Turnip White-Tipped.

DWARF ESSEX RAPE, for SALAD.

Culture-One ounce to 50 feet; drill thick in spring, rows 2 feet apart, or sow in August, September and October; 10 pounds to acre.

For the garden it practically can be sown and cut every month in the year except summer. Excellent for fall or spring greens when boiled. Thin out when 6 or 8 inches high to 6-inch plants, and col when sown in fall for greens cut of tops when 12 inches high above the bud and greens cut off tops when 12 inches high above the bud and
use. Tops grow out again and may be cut several times. use. Tops grow out again and may be cut several times. cheap greens. Price, packet 5c; 4ounces $10 \mathrm{c}$; pound $25 \mathrm{c}$ 5 pounds at $20 \mathrm{c}$ per pound.

\section{SALSIFY, or OYSTER PLANT.}

One of the best and most popular winter vegetables. Boil and serve in sauce, or make into fritters; the flavor is like fried oysters.

Culture-Sow in March or April in a rich, light, deeply worked soil, in rows 18 inches apart, and thin out 4 to 6 inches. Do not use coarse or fresh manure. Cultivate of ten to keep down weeds. It is hardy and may remain out all winter. Can also be sown in May and June, provided we get seasonable weather or boards be used to get the seeds up and shade the young sprouts until they get established. Market September to March 15th. Ready in 110 to 125 days. Plant also September to October. Let plants remain in the ground till used. One ounce sows 50 feet of drill; 8 pounds, one acre. Germinates within 1 or 2 weeks.

SANDWICH ISLAND MAMMOTH-The new salsify g:rows nearly twice the size of the old sort, and is superio in quality. Packet $5 \mathrm{c}$; ounce 20c; 4 ounces $60 \mathrm{c}$; pound $\$ 1.75$.

\section{SPINACH.}

Culture-Plant January 15th to April: August to November. One ounce to 100 feet of drill. 20 pounds to vember. For winter, sow in drills 1 inch deep rows 9 inches acre. For winter, sow in drills, 1 inch deep, rows 9 inches table. For summer use, sow in spring. Less coarse than some other "greens" ; largely used in the South. Southern truckers ship immense amounts. North. For Northern market plant in August. Yields 150 to 200 bushels per acre. Used as greens and helps to make a boiled dinner. Usually a winter crop and the ground occupied by it is then planted down to other crops. Germinates badly - takes 10 days. Ready in 60 to 70 days. Soak seed over night before plant-

ing; germinates within 1 or 2 weeks.
For Succession Spinach can be followed by bush squash from April 1st to April 15th; and by bush or pole snapbeans for late crop from. July 15th to August 1st.

NEW ZEALAND SPINACH (of the chenopodium family), also called New Giant. First cutting sixty days after sowing, and continuous cuttings for 100 days thereafter. Totally unlike other spinach. Remains in edible condition.10 times longer than other spinach. TWhenever broken off it sends out a fresh wide growth. The plant spreads five times as wide and rises about three times to height as or dinary spinach; thus affording 15 to 20 times the rolume of edible material. Its foliage is thick, juicy, and succu-

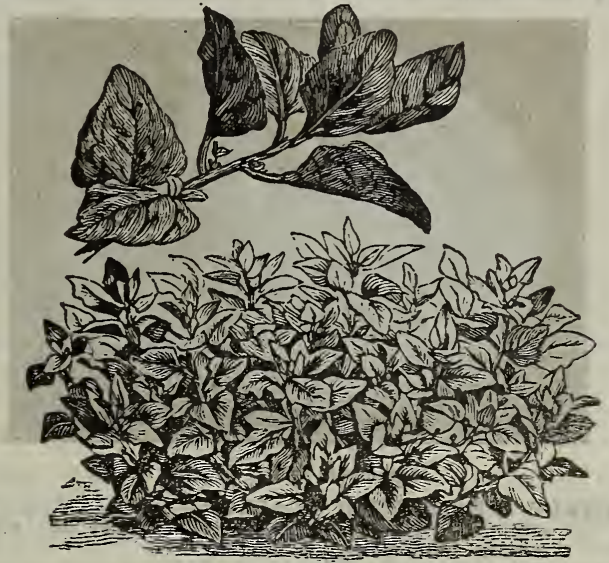

New Zealand Spinach.

lent, dark green, and absolutely heat resistant; and leaves lent, dark green, and absolutel like an ice plant. Can be are through hottest summer months, when other spinach is unobtainable, and remains in cutting condition until frost. Plant spring and fall, 1 ounce to 100 feet drilled, and 10 pounds to the acre. All epicures announce this as bein the choicest of all spinach. Is delicate as asparagus. Cooks tender like marrow. Fine for canning. Best to soak seed, plant sliallow March or April; will stay green till frost, continuously edible all the while, and will then reseed itself if allowed to do so. Price, packet $5 \mathrm{c} ; 1$ ounce $20 \mathrm{c} ; 4$ ounces $50 \mathrm{c}$; pound $\$ 1.50$.

LCNG S'TANDING-A deep green variety, with rather elongated, smooth leaves; seed round, stands a long time without running to seed. Packet $5 \mathrm{c}$; ounce $15 \mathrm{c}$; $1 / 4$ pound $40 \mathrm{c}$; pound $\$ 1.00$

BROAD IEAVED FLANDERS-A compact, broad-leaved sort. Leaves are round and rery thick, and of the best quality, not so early as Bloomsdale Savoy, but a desirable sort for main crop. Packet $5 \mathrm{c}$; ounce $15 \mathrm{c}$; $1 / 4$ pound $40 \mathrm{c}$; pound $\$ 1.00$.

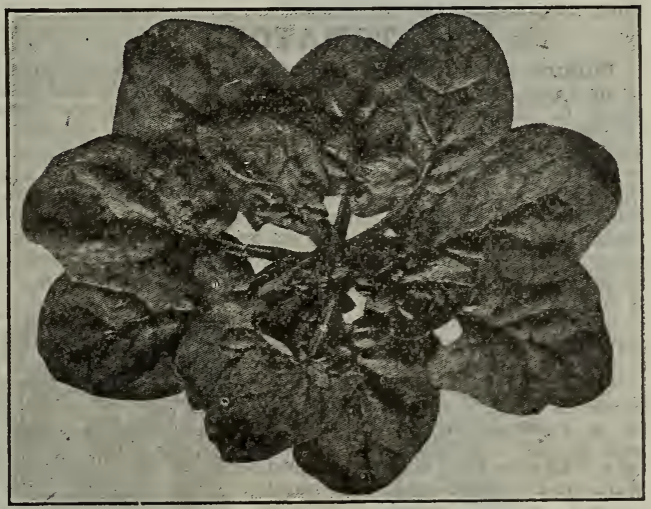

Bloomsdale Savoy Spinach.

BLOOMSDALE SAVOY-The variety most used in the East, and especially, throughout the South for shipping. Leaves are large, round and thick, very much savoyed and rich, deep green. One of the earliest varieties; seed round. Packet $5 \mathrm{c}$; ounce $15 \mathrm{c} ; 1 / 4$ pound $40 \mathrm{c}$; pound $\$ 1.00$.

\section{SQUASH.}

Culture-After frost is past, plant in a warm, well pulverized, rich soil April to August, 8 or 10 seeds to the hill, the bush varieties 4 to 6 feet apart, the running sorts 8 to 10 feet. When well grown thin out, leaving three of the strongest plants in each hill. Apply Slug Shot or Paris Green to keep off bugs. Summer sorts, 1 ounce to 25 hills 4 to 6 pounds to an acre. Winter sorts, 1 ounce to 100 hills : 4 to 5 pounds to an acre. Ready 70 to 80 days. Market Mav, through fall and winter.

MAMMOTH WHITE BUSH-Of true bush growth, nearly as early and double the size, as the Early White Bush, 
and produces large, thick fruits with scalloped edges-frequently 12 to 14 inches in diameter. Packet $5 \mathrm{c}$; ounce $20 \mathrm{c} ; 4$ ounces $50 \mathrm{c}$; pound $\$ 1.25$.

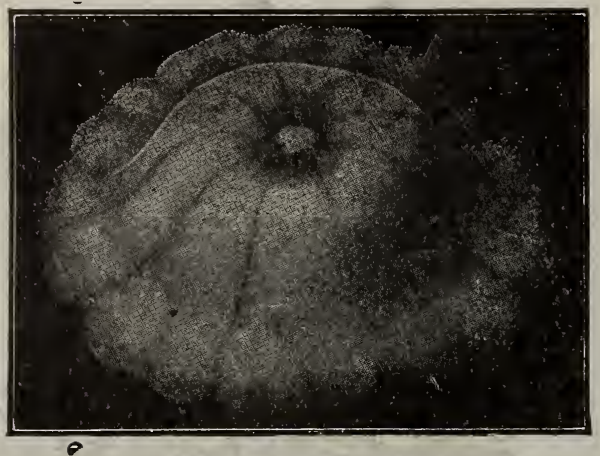

Mammoth White Bush.

EARLY WHITE BUSH SCALLOP-Early, well known by all; ships well; a summer dwarf. Packet 5c; ounce $20 \mathrm{c} ; 4$ ounces $50 \mathrm{c}$; pound $\$ 1.25$.

SUMMER CROOKNECK-Early; fruit yellow; hard shell; watery excrescences. Packet $5 c$; ounce $20 c ; 4$ ounces $50 c$; pound $\$ 1.25$.

BOSTON MARROW-A fall and winter variety; large size, oval form, skin thin; when ripe, bright orange with a netting of light cream color; flesh rich salmon yellow. Packet $5 \mathrm{c}$; ounce $20 \mathrm{c} ; 4$ ounces $50 \mathrm{c}$; pound $\$ 1.25$.

HUBBARD-The most popular of all winter varieties; an excellent keeper. Is of large size, often weighing from 9 to 20 pounds. Color is bluish green, occasionally marked with a brownish orange. Flesh is fine grain, dry and excellent flavor. Are also eaten in summer, being a better summer dish than White Bush. Make finest squash pies. Packet 5c; ounce 25c: 4 ounces 60c; pound $\$ 1.50$.

COCOZELIE, or ITALIAN MARROW-A distinct $\mathrm{va-}$ riety; skin smooth; of a dark green or pale green in stripes. The fruit is best when 8 to 10 inches long; very popular among the Italians. Look like an overgrown cucumber. Sliced and fried, can't be told from Eggplant. Boiled like White Bush Squash, they are a drier, sweeter dish. A fine summer squash. Plant up to August. A charming new squash. Have long vines, and should be given 8 feet between hills. Packet $5 \mathrm{c}$; ounce $25 \mathrm{c} ; 4$ ounces $65 \mathrm{c}$; pound $\$ 2.00$.

\section{TOMATOES}

Culture-Sow in late February in hotbeds; transplant after frost, three feet apart. Pinch off laterals and confine fruit to stem. Tie to a stake, or for a large acreage use the $V$ trellis system. For a fall crop are valuable for ripe or green fruit. Sow about June 1st for August 1st planting out, and for October crop, 1 ounce for 1,000 plants. Ready 90 to 100 days. Market May 15th through October. The V trellis system: Run a row of stakes in "middles', and place a continuous rider on top of same, and from the rider plos to base of tomato plants on either side, and cutting back laterals, train tomatoes to grow. This makes a convenient arbor of the middles

of rows. Plant tomatoes

in Florida September to January.

HUFFMAN'S EARLIEST Stalk is that of the Earliana, but is a week earlier, better color and better fruited; has no culls like Earliana; tomato round dark red; small core and small seeded cells. Large shipments were made last year weighin over a pound each, 12 to a baske and 72 to a crate.

Absolutely the earliest tomato known. It has been thoroughly tried out. Boggs, of Dalaware, and Pedrick, of New Jersey, to mato experts, declare this to be the earliest tomato, ripening with them June 5 th to June 15 th and them Jurlier than Ripe toDelaware by June 3d. Anyone familiar with the usual ripening time of tomatoes will see at once what a remarkable production, and what a valuable one, is thi Huffman Tomato. It was pro duced near Augusta, Ga. It has been known here three or folir years. One trucker here marketed 46 Huffman Tomatoes from early June to August 15 th from one plant. Packet $5 \mathrm{c}$; ounce $50 \mathrm{c} ; 4$ ounces $\$ 1.25$; pound $\$ 4.50$.

SPARKS' EARLIANA-(Bright Red) $\$ 4.50$. probably more largely grown for the early market than any other tomato of all the large, bright red varieties. In the tomato growing section of New Jersey, which practically controls the Eastern markets, it is grown almost ex-

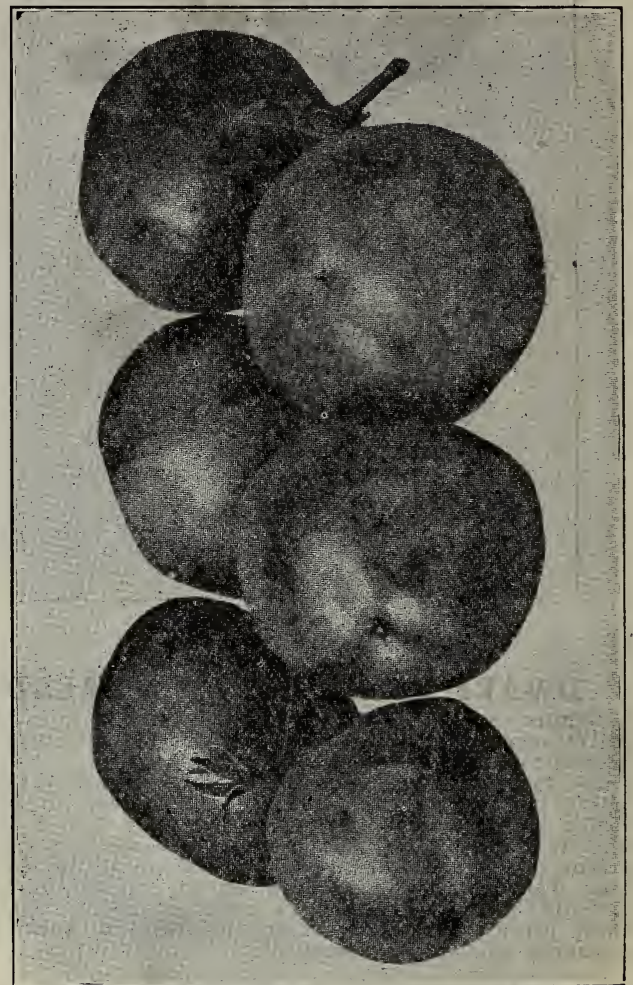

Sparks' Earliana.

clusively. It is of very handsome shape, quite solid, and of fine quality. The fruiting season only lasts about four weeks, so that if marketed early the crop may be sold before the markets are glutted with the later kinds. Our truckers here believe this to be our best tomato. Grows big (12 ounces often) and prolific; three or four often in bunches. Smooth, round, pink; no ridges. Packet 5c; ounce $30 \mathrm{c} ; 4$ ounces $80 \mathrm{c} ;$ pound $\$ 2.75$.

WIILET'S GOLDEN PONDEROSA-A new delightful delicate flavored tomato. Should be grown by every one.

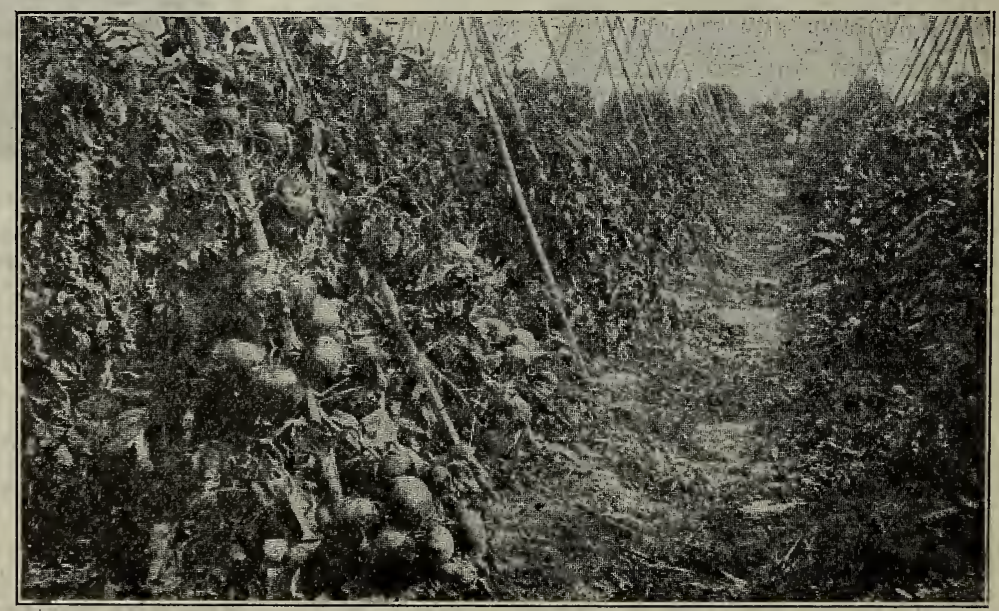

Huffman's Earliest. 
Weighs often two pounds. Immense in size. Exquisite individual flavor unlike Red Tomatoes. Tender and delicious. When ripe cut in half and eat with a spoon with powdered sugar. A decorative table effect is made with a mixed dish of Red and of this Golden Yellow Tomato. Packet $5 \mathrm{c} ;$ ounce $50 \mathrm{c} ; 4$ ounces $\$ 1.25$; pound $\$ 4.50$.

THE STONE TOMATO-Solid; good carrying qualities; color, rich red; shape, perfectly smooth and thicker than most kinds from blossom end to stem. Large in size and heavy cropper. Packet 5c; ounce 20c; 4 ounces 60c; pound $\$ 2.00$.

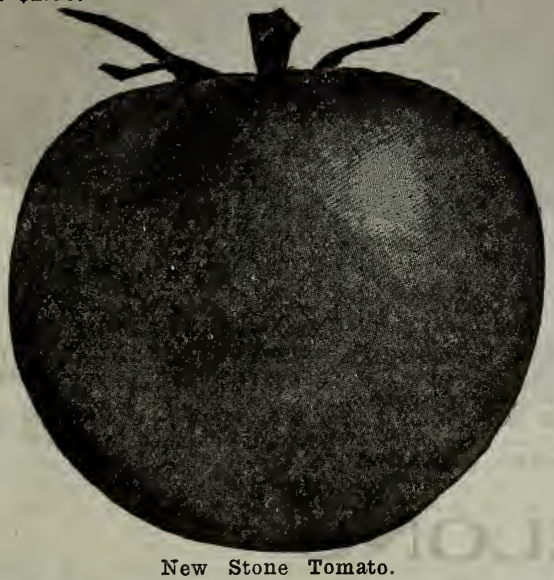

LIVINGSTON'S FAVORITE-Large, smooth, productive, good shipper; does not crack open. Packet $5 \mathrm{c}$; ounce $20 \mathrm{c}$; 4 ounces $60 \mathrm{c}$; pound $\$ 2.00$.

GOLDEN OUEEN-Yellow flesh, superior, distinct flavor: beautiful fruit. Packet $5 \mathrm{c}$; ounce $30 \mathrm{c} ; 4$ ounces $80 \mathrm{c}$; pound $\$ 2.50$

PONDEROSA-Very often 2 pounds; immense in size; a veritable curiosity. A large solid mass of meaty succulent flesh to each tomato. Irregular fruited variety; vine tall and fruit very solid and purplish carmine color. Packet $5 \mathrm{c}$; ounce $45 \mathrm{c} ; 4$ ounces $\$ 1.10$; pound $\$ 3.75$.

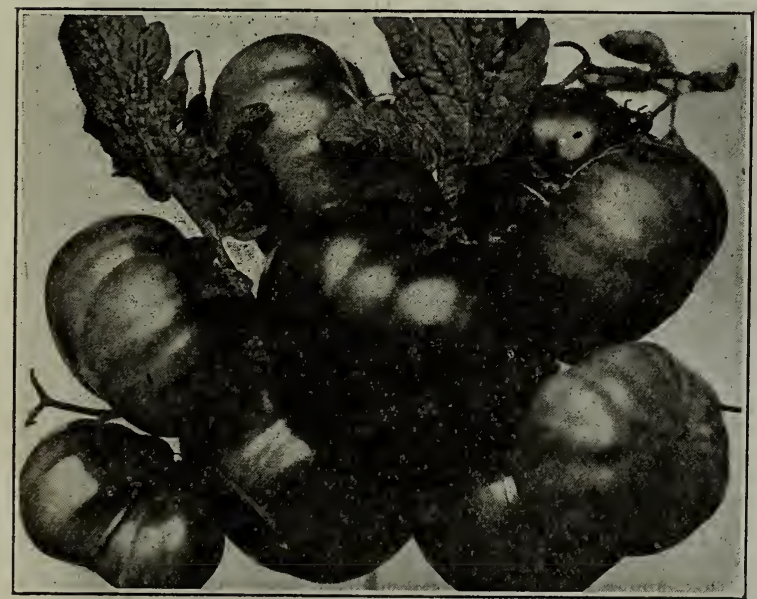

Ponderosa Tomato.

NEW EARLY ACME-Pinkish purple; heavy bearer; round, solid; bears till frost. Thin ckin. Packet $5 \mathrm{c}$; ounc $20 \mathrm{c} ; 4$ ounces $60 \mathrm{c}$; pound $\$ 2.00$.

MATCHLESS-The finest and best of the new canning tomatoes. Color same as Acme, but larger in size better shipper and canner. The canner's favorite. Packet $5 \mathrm{c}$; ounce $20 \mathrm{c} ; 4$ ounces $60 \mathrm{c}$; pound $\$ 2.00$

DWARF CHAMPION-A dwarf variety; upright growth ability to stand alone without trellising; fruit medium sized, smooth and of purplish carmine color. In largest use by truckers to save stakes and trellises. Packet 5c; ounce $40 \mathrm{c} ; 4$ ounces $\$ 1.00$; pound $\$ 3.00$

TOMATO PLANTS-We can furnish, from April until June, f. o. b. growers in Florida or South Carolina coast, Earliana, Globe, Ponderosa, Stone. Also for August ist delivery. 100 for $\$ 1.00 ; 500 \$ 2.50 ; 1000 \$ 4.00$. No orders shipped unless accompanied by cash.

\section{TURNIP and RUTABAGA SEED.}

Culture-Plant January to March; July, August, September, October. Spring sowing should be put in early so that they will attain a good size before hot weather, otherwise will become tough and bitter. For spring sowing the Milans, Strap Leaf (Flat Dutch and Purple Top), Globe and Salad Turnips, are best. For regular crop, sow varied sorts in July or August, September and October. Sow either broadcast or in drills, 2 feet apart, thinning out to 6 inches and roll the ground after sowing. Rutabagas should be sown in July and early in August, and earthed up as they grow. Ready in about 85 dasy. Market summer, fall and crimson clover and one pound of turnip seed mixed per acre in late summer time; gather turnips early in winter and graze crimson through winter, and in spring get a fine crop of hay. We import tremendous amounts of highest grade foreign seeds, and are heavy contractors of American-grown types, and heavy contractors, too, especially of Southern-grown types. One ounce for 100-foot drill. Sow 11/2 pounds to the acre in acre. Plant turnips in Florida any time, fall and winter.

WHITE-FLESHED VARIETIES.

EXTRA EARLY PURPLE TOP MILAN-The earliest of all flat turnips. The roots are clean, smooth, flat and handsome. The flesh is pure white, tender and sweet. Packet $5 \mathrm{c} ; 4$ ounces $90 \mathrm{c}$; pound $\$ 2.60$.

EXTRA EARLY WHITE MILAN-Similar to the above except that it is white all over. Packet $5 \mathrm{c} ; 4$ ounces $90 \mathrm{c}$; pound $\$ 2.60$.

EARLY WHITE FLAT D U T C H(Flat strap-leaved) -Exactly like Early Red or Purple Top, except that it is pure white. One of the best for the $f$ a mily garden; sweet and tender. Packet $5 c ; 4$ ounces $60 \mathrm{c}$; pound $\$ 1.35$. EARLY RED, or PURPLE T O P(Flat strap-leaved) -Flat, white with purple top; finegrained and tender. The most popular the best seller. Packet 5c; 4 ounces $65 \mathrm{c}$; pound $\$ 1.50$. E A R I Y MAMMOTH RED TOP WHITE GLOBEMakes large globeshaped roots, white with purple tops. A big yielder; fine

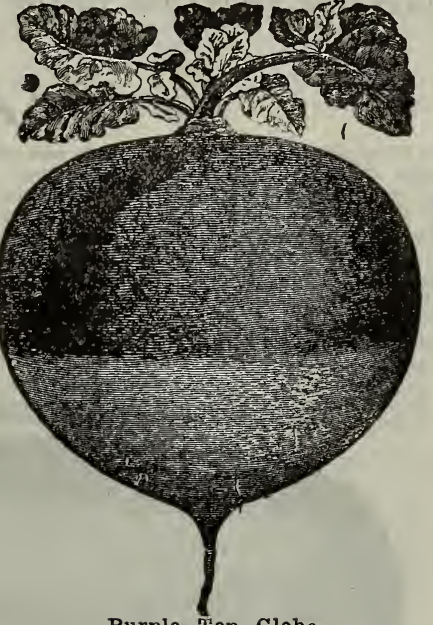

Purple Top Globe. for table, market and stock feeding. An Augusta favorite. Planted at Augusta February 6th made fine turnip weigh. ing $5 \mathrm{lbs}$. and over. Packet $5 \mathrm{c} ; 4$ ounces $80 \mathrm{c}$; pound $\$ 2.50$.

POMERANIAN WHITE GLOBE-Extra large, round, white; fine for table and stock; a big. yielder. Packet 5c; 4 ounces $60 \mathrm{c}$; pound $\$ 1.35$.

WHITE EGG-A quick-growing, egg-shaped, smooth, pure white variety with small tops. Flesh sweet, firm and mild. Packet 5c; 4 ounces $60 \mathrm{c} ;$ pound $\$ 1.35$.

LARGE WHITE COWHORN-A very productive quick-growing tur. nip of excellent quality, tine-grained and very sweet. Often used as a soil improver. $\$$ Pack

LARGE WHITE NORFOLK GLOBE-Makes large, round white roots, excellent for table or stock; also quite largely used for winter also quite largely used for winter salad. An Augusta trucker who had five acres of White Norfolk

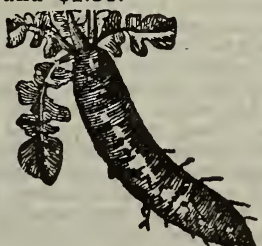

Cow Horn Turnip November turnips that weighed five pounds, tops and bot. toms-some of them bringing five and some of them $10 \mathrm{c}$ each retail. Packet $5 \mathrm{c} ; 4$ ounces $60 \mathrm{c}$; pound $\$ 1.35$.

GREYSTONE TURNIP-Great English favorite. Is darkish in color. Extra large turnip and an extra liardy turnip among all of the white turnips. Top is purple; flesh exceedingly firm; an excellent and perfect keeper among all of the winter turnips. Prime favorite. New here. Packet $5 \mathrm{c} ; 4$ ounces $60 \mathrm{c}$; pound $\$ 1.35$.

YELLOW FLESHED VARIETIES PURPLE-TOP YELLOW ABERDEEN-A splendid keeper. Flesh is yellow, very solid, tender and sweet. Hardy and 9 good rieller; fine stock turnip. Packet $5 \mathrm{c} ; 4$ ounces $60 \mathrm{c} ;$ pound $\$ 1.35$. 
LARGE AMBER, or YELLOW GLOBE-Of iarge sjze, globe-shaped, solid yellow flesh. Fine for table and stock; a fine keeper. Packet $5 \mathrm{c} ; 4$ ounces $60 \mathrm{c}$; pound $\$ 1.35$.

GOLDEN BALL, or ORANGE JELLY-One of the sweet est and best yellow turnips; hardy; flesh is firm ard of most excellent flavor. Packet $5 \mathrm{c} ; 4$ ounces $60 \mathrm{c}$; pound $\$ 1.35$. SALAD VARIETIES.

SEVEN-TOPS-Seed grown in Georgia (United States trade habit of stooling or branching into seven tops. Makes great amount of salad or greens. Does not make big roots. We are Southern headquarters for Seven-Tops. Packet quarters for Seven-Tops. Packet

GEORGIA FROST KING, or SOUTHERN PRIZE-Seed trade supplied. Differing from SevenTops which simply "tops," the Southern Prize has large, white tubers cellent, lasting through winter till late spring, when other turnips are pithy. This turnip's root is both large and tender, and finely flavored; superior foliage to other white turnips; it also provides foliage or greens as luxuriant and $\$ 1.25$.

\section{Rutabaga or Swede.}

IMPROVED PURPLE-TOP YELLOW-The old standard variety; largely grown for table stock. A large yielder and good keeper; hardy and solid. Packet $5 \mathrm{c} ; 4$ ounces $80 \mathrm{c}$; pound $\$ 2.50$.

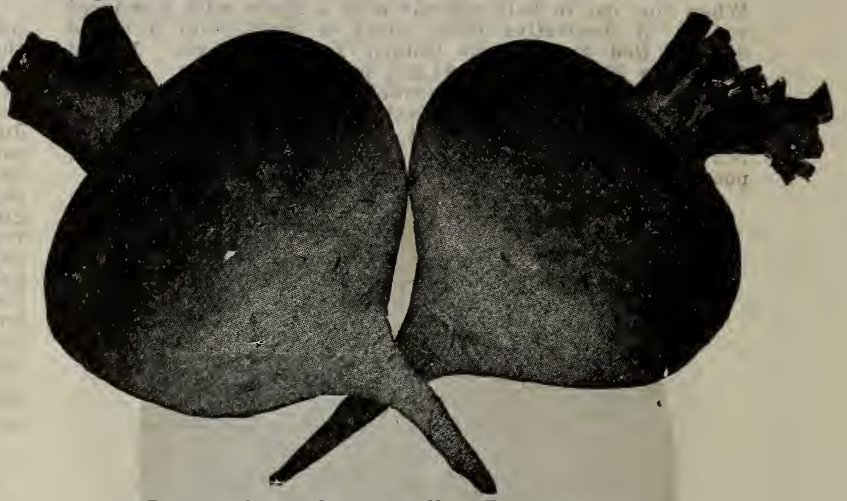

Improved Purple-Top Yellow Rutabaga.

BON AIR, or GOLDEN NECKLACE RUTABAGA-The largest rutabaga in existence. Strictly American. Packet $5 \mathrm{c} ; 4$ ounces $80 \mathrm{c} ;$ pound $\$ 2.50$.

LARGE WHITE, or RUSSIAN-Flesh is white, firm and sweet; grows large; fine for table and stock. Packet 5c; 4 ounces $75 \mathrm{c}$; pound $\$ 2.00$.

\section{WATERMELONS}

An important melon seed test was made for us by the South Carolina Experimental Station. This test showed that Augusta, Ga., grown seed produces melons 10 to 15 per cent larger than seed from Florida or Western melon seed; and that while Georgia seed made two large shipping melons to the vine Florida and Western seed produced 5 small melons per vine. Georgia seed, too, produces sweeter melons. Colorado, Kansas, Oklahoma melon seed produce here often, yellow, hard, cankered centers in melons-centers that do not mature.

Watermelon Diseases-Watermelons are largely infected with anthracnose or spots. To prevent anthracnose, spray vines thoroughly with dry Bordeaux Mixture 30 days be fore maturity of crop. For stem-end rot, rub with dry Bordeaux Mixture the freshly cut stem on the melon, as melons are being loaded on car. Get Farmer's Bulletin 821 . See Insecticide page.

For Melon Aphis-Use Black Leaf 40.

WATSON-See Cut. Almost seedless, some not having one-third as many seed as other melons. The biggest Florida shippers plant Watson. Weigh 30 to 60 pounds, one grown at Augusta
103 pounds. Our seed are the choicest. Originated near Augusta; very prolificsix carloads on ten acres often made. Shape long; color dark, deep green; no stripes; large-two melons to the vine: no ends; no necks to rot; better shipper no ends; no necks to rot; better shipper - than Rattlesnake; tougher rind; flesh low. The finest Watson grown this year were planted after oats and weighed 60 and 75 pounds here at Augusta. A large Georgia grower says: "I've grown all the melons; Watson is best of all. Will ship further and keep in commission house longer than any melon. Have kept them till Christmas." Ninety per cent of the till Christmas. Ninety per cent of the
melons now shipped North are Watson. Western-grown seed are mixed with Kleckley and no good. Meat firm and not

Watson Watermelon.

NOTE-We know individual Georgia melon truckers who have each lost $\$ 3,000$ to $\$ 5,000$ from using cheap Colorado melon seed, and the still cheaper Florida melon seed. We are the only seed house in America, we believe, who refuse to handle this Florida and Western watermelon seed-seed that can be bought by jobbers at 25 cents a pound.

All melon seed listed below are grown about Augusta, Ga. Seed trade supplied. We are in the largest and very best melon shipping district in the United States. Augusta inaugurated in 1867 melon shipping business Northward. Our seed are taken from 20-pound melons and above -8 to 10 melons to one pound of seed. We sell the large truckers who would not dare use the $25 \mathrm{c}$ contract melon seed as supplied to United States seed trade from Florida and

Culture-Plant in spring 10 seed to hill and thin out to two. One packet to 30 hills, and 4 ounces to 100 hills there being about 200 seed to the ounce. Plant 6 seed to hill and thin out to two. Plant melons in Florida January and May. Watermelons sometimes grow $1 \frac{1 / 2}{2}$ pounds per day in June.

Some plant hills $10 \times 10$ feet, and some $8 \times 12$ feet. The guano often used per acre is 200 ponds cotton seed meal, 100 pounds acid phosphate, and 100 pounds kainit; 400 melons, or one-half of a car per acre, usually obtained. Ripen from June 15th to July 3 d. The truckers about here plant about $1 \frac{1 / 2}{2}$ pounds per acre. We usually plant Spanish peanuts or Velvet Beans in middles. Plant March 15th to April 25 th, and June 15 th to July, after grain. so good an eater as Sugar Loaf, Rattlesnake and Kleckley. Through use of poor seed stock, much of Watson sadly degenerated in 1917-thin narrow melon with small ends. Buy our seed. We are the largest jobbers here of Augustagrown seed. Packet 10c; 4 ounces $30 \mathrm{c}$; pound $\$ 1.00$.

"JUNE 10TH" -Known as Augusta Round White and "Sheep Nose." Mature here June 12th to 15th. All others mature about July 4th. Best earliest home market. melon known. Not a good shipper. Short vines, but heavy bearers. Plant thick. Tender rind. Flesh light red. Sweet, brittle, good flavor. Shape round. Color whitish. Melon 15 to 20 pounds. A great acquisition among melons. Bears continually during season. This melon is grown here exclusively by all our market men for the earliest home market. Only listed by us. Packet $10 \mathrm{c} ; 4$ ounces $30 \mathrm{c}$; pound $\$ 1.00$.

AUGUSTA SUGAR LOAF-A long, gray or greenish white melon, with crisp, red flesh, with as thin rind as Rattlesnake. Grows to an immense size-a whole market wagon load running often to 60 pounds each. Medium early-ripens about July $3 \mathrm{~d}$. Originated around Augusta. A beauty to look at and a delight to eat. Never has gourd ends. No better eating melon known. The cut of Watson would do for Sugar Loaf. Same shape, but Sugar Loaf is green-white or gray, whereas Watson is deep green. Packet $10 \mathrm{c}$; 4 ounces $30 \mathrm{c}$; pound $\$ 1.00$. 
GENUINE AUGUSTA RATTLESNAKE-See Cut. Called, too, "Stripes" and "Gypsy." This melon seems to deteriorate the second year when grown elsewhere than in this county. It originated here in Augusta, and has been one of the most advertised of all melons. This seed should be had each year from this county. This was the original melon shipped North in 1867, which so whetted the Northern appetite for watermelon. It is an elongated gray, with green stripes; good size with maximum of 50 to 60 pounds; seed white, with black ears; flesh crisp and excellent; a choice home melon; ships with careful packing. Medium earlyripens about July $3 d$. Ours are the highest type of seed. Packet $10 \mathrm{c} ; 4$ ounces $40 \mathrm{c}$; pound $\$ 1.25$.

FLORIDA FAVORITE-A prime favorite for home consumption. Has dark skinfi light green stripes and crimson flesh; exceedingly sweet; early; ripens about June 28 th. Packet $10 \mathrm{c}$; 4 ounces $30 \mathrm{c}$; pound $\$ 1.00$

EXCEL MELON-Run 45 to 65 pounds Melon is grayish; looks much like Sugar Loaf. A heavy bearer; larger melon than Watson. Seed are some black, some white One serious Seed are some black, some white. One serious drawback is that the melon must not be picked
when seemingly grown, but must stay on the vine growing and mellowing, for a week, or else meat is not sweet and crystalline; is often pick ed therefore, too green. Packet 10c; 4 ounces $25 \mathrm{c}$; pound $90 \mathrm{c}$

HALBERT'S HONEY-Oblong, but blunt, 20 to 30 ins. long, weighs 25 to 60 lbs. Color glossy deep green. Seed dusty white, brown tips. This is the great Texas Eating Nelon. Thin rind Sugary sweet flesh. Not a shipper. Packet $10 \mathrm{c} ; 4$ ounces $30 \mathrm{c}$; pound $\$ 1.00$.

NEW HOLMES-Shape, large round, like Eden, but longer; color dark green, with very dark stripes; seed black; very prolific, matures as early as Eden. Mr. J. with 30 years' experience as a grower and shipper, writes us: "Now selling car after car New Holmes at $\$ 175$ pe car f. o. b. my station, while Watson, Kolb Gem and-Eden are bringing maximum of $\$ 150$. New Holmes grows large, perfect in shape, longer than Kolb Gem, and has a thick, durable rind, stands shipping to any point. About 750 Holmes melons fill a car 36 feet long, 8 feet wide, 4 ieet deep. I regard it as the finest, melon I ever saw, and I have raised tho $25 \mathrm{c}$; pound $90 \mathrm{c}$

SPANISH MELON-The favorite watermelon in Spain and might be tried out in a Home Experiment way. The Consul of U. S., Valencia, Spain, thinks highly of it. Packet $10 \mathrm{c} ; 4$ ounces $30 \mathrm{c}$; pound $\$ 1.00$.

KLECKLEY SWEET-Melts in the mouth. No pulp left. Oblong, of medium size and sweet, with but few whit seeds firmly set near the rind Vines strong growing, prolific and numerous $t$ othe vine; melons not large-about 20 pounds; rind too thin for shipping. So popular is this home-eating melon that the supply each year of seed i exhausted and the market is bare of seed before season is out. Rind dark green; flesh bright scarlet and ripens to

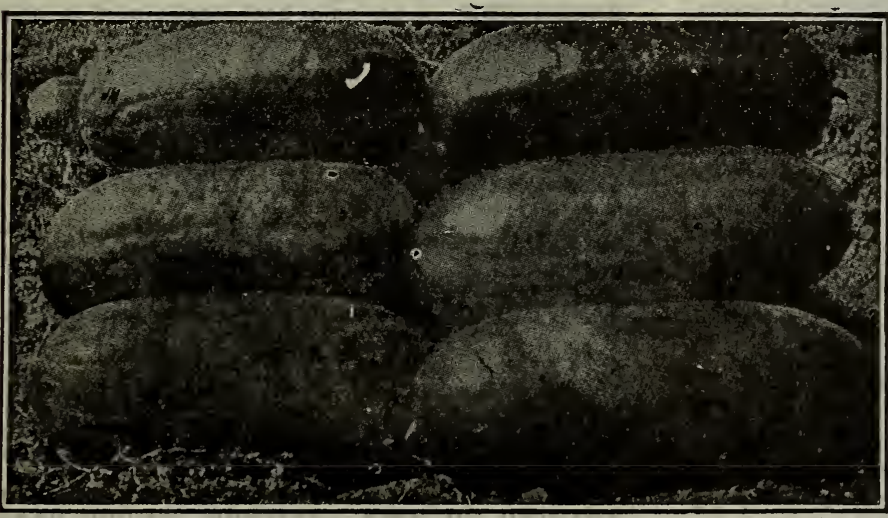

Klsckley Sweet Watermelon.

within half an inch of the rind. Quality of the meat is rich and sweet, hence its name. For the home market or family garden it is universally known as being without a stiperior. Ripens about July $3 d$; medium early. A favor ite in Northwest. We have fine Georgia-grown seed. All Northwestern seed seem to be mixed some with citron seed and some with Watson. Prolific, 3 to 4 to the vine. Packet $10 \mathrm{c}$; 4 ounces $30 \mathrm{c}$; pound $\$ 1.00$. $30 \mathrm{c}$; pound $\$ 1.00$
ALABAMA SWEET-Shape, long to oblong. Excellent shipping melon; the leading sort grown by Texas growers and some other Southern melon growers' associations, and rind is dark green, marked with a still darker green mot-

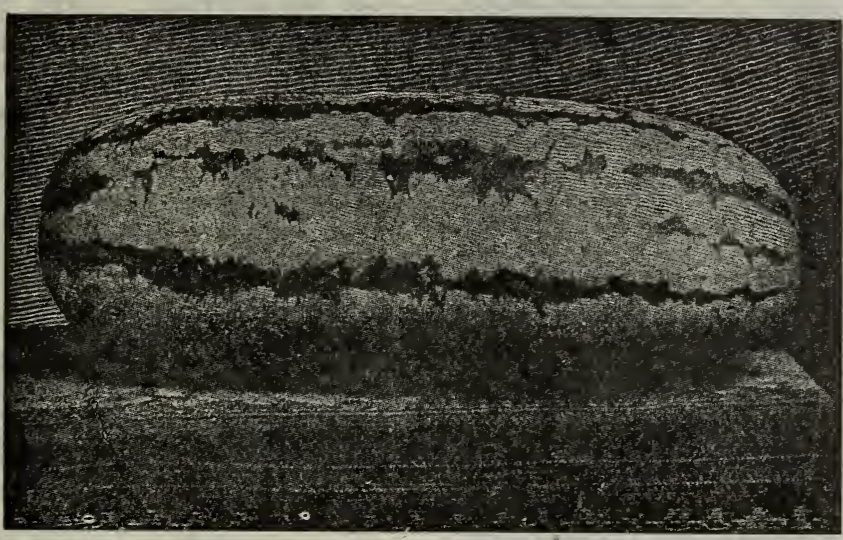

Augusta Rattlesnake Melon

tled stripe, and while thin, it is very tough. making the melon a first-class shipper. The flesh is bright red, finegrained, swcet and luscious, entirely stringless and very firm. The seeds are white, slightly tipped with brown, and are firmly set in small cavities near the rind. Packet $10 \mathrm{c}$ 4 oinces $30 \mathrm{c}$; pounü $\$ 1.00$

EDEN-Round; striped; cuts rich red; 1,000 to 1,100 to car. By shippers is thought to be better than Kolb Gem. Bluish cast melon and elongated; larger than Kolb Gem; far better eater and seller than Kolb Gem. Seed white. Medium early; ripens about July $3 \mathrm{~d}$. Planted in South Carnlina largely. Packet $10 \mathrm{c} ; 4$ ounces $25 \mathrm{c}$; pound $90 \mathrm{c}$.

BLUE GEM, or GLOUSSIER, or BLACK BOULDER, or ICE BERG-As good a shipping melon as Kolb Gem; quality better and flavor sweeter; a far better keeper; somewhat longer and heavier than Kolb Gem; very dark bluish green rind, small grayish stripes, bright red flesh; seed black; as good a shipper as Kolb Gem, while quality of meat is far better; will keep longer than any known melon; $10 \mathrm{c}$; ounse $25 \mathrm{c}$; pound $90 \mathrm{c}$.

THE JONES-Rind dark, flesh bright red; almost round in shape; rind trifle thicker than the above melon; 65 to 70 pounds frequently size of this melon. Originated near us some years ago, and is one of the very best. Medium early; ripens about July 3d. A grower at Augusta, this season, grew Jones melons weighing 80 pounds. Good for hrme markets, but they break in shipping. Has a thick rind and is better than all other melons for rind preserving purposes and pickling. Packet $10 \mathrm{c} ; 4$ ozs. $25 \mathrm{c}$; 1b. $90 \mathrm{c}$. TRIUMPH-Has given almost universal satisfaction for shipping and market purposes. The rind is dark green color, with indistinct stripe; flesh deep crimson, ripening up evenly and of very fine quality The largest of all melons-have weighed 120 pounds. Late, ripens about July 10 th. A favorite in its home state, pound $90 \mathrm{c}$.

IMPROVED KOLB GEM-Is about the same shape as the old-fashioned Kolb. Dark green rind, with a distinct stripe of lighter green. Black seed, more. pro lific and attractive than the old kind deep red flesh and not so tough and whitehearted as the old kind. 30 -pound fair 10c: 4 ipens about July $4 \mathrm{t}$

COLORADO PRESERVING CITRON-

A medium-sized round melon which grow about 6 to 8 inches in diameter and is striped with an alternate light and dark green stripe with green seed. Used for making sweet pickles and preserving. At Augusta these melons averaged 15 or 20 to the vine, averaging 15 pounds to the melon. Some ran as high as 31 pounds. Need no cultivation whatever and aside from their use for preserving and for sweet pickles, they are as fine for stock as is the Kansas Stock Melon. Will stay on the ground in winter and not rot. They are a most valuable farm crop. Hard, firm, white meat. Packet 5c; 4 ounces

KANSAS STOCK MELON-See Cut. Vines and culture same as watermelon. Resembles Citron and Apple Pie 
Melon, but is larger, weighing 30 to 40 pounds. Grow on poor soil best. Light green and striped in color. In large use in Kansas for hogs, cows and poultry. Will keep through the winter. Makes 15 tons food per acre, or 20 themselves for the next season, coming up and growing without cultivation nattle turned in on a field of same say in October, will fatten on it without other food and of South Carolina where it has been grown. The melon grows to a large size; rind dark green with darker stripes flesh red and remarkably tender and sweet; an excellen melon for home use; medium early; ripens about July 3d. Large, of ten 70 pounds. Rind tough. Packet 10c; 4 ounces $30 \mathrm{c}$; pound $\$ 1.00$.

APPIE PIE MIEION-1/2 pound per acre Vine, fruit and culture quite similar to a watermelon, and are easily

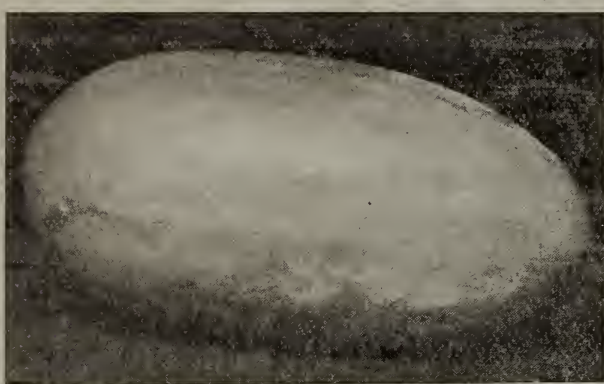

Kansas Stock Melon.

without water as long as the melons last. A party here in Augusta made 107 melons of about 20 pounds each on 27 hills, on the poorest of sandy worn-out land, without a particle of cultivation except the mere planting. Parties here like it better than the Pumpkin, for the Pumpkin is not prolific, requires rich land, and they require storing away. Horses, cows and hogs eat this melon as chopped up, with intense avidity. The meat is as solid as a pumpkin. We kept one melon last season for eight months in the store and cut it June 1st. and it was perfectly sound; it would have kept a year. Meat is a light yellow with a pleasant have kept a year. Meat is a light yellow with a pleasant pound $\$ 1.25$. Use $1 / 2$ pound per acre.

CAROIINA BRADFORD-Known as Hoke Smith, Mc Guire, Tinker and Pearson. Long a favorite in the section

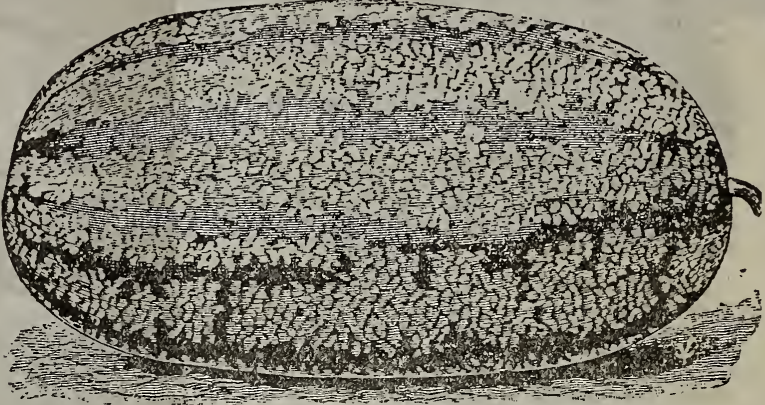

Carolina Bradford Melon.

grown on any good soil. Each vine produces from 5 to 15 fruits and one of the large size will make as many pies as $1 / 2$ bushel apples. Flesh is white, solid throughout, and of excellent quality for making pies, sauce, preserves, etc. and resembles apples in flavor. They keep nice and fresh all winter so they can be used any time and any surplus can be fed to the livestock. It will pay to raise them for this alone, as they can be kept and fed all winter. Is a big, very hard and solid melon, weighing usually 20 pounds, of a light yellowish green color. It can be used for every purpose that apples are used for except eating raw. They are good keepers, remaining sound until the next summer. pound $\$ 1.25$.

\section{HERBS FOR FLAVORING}

\section{AND MEDICINAL USE.}

Culture-Soil for herbs should be carefully prepared and well cultivated as the plants are for the most part delicate and easily choked out by weeds. Sow early in the spring, in drills 16 to 18 inches apart, and transplant as soon as the plants are large enough.

To Preserve the Plants for Use During the Winter, the plants should be cut when in bloom and wilted in the sun and thoroughly dried in the shade, and then kept in jars or bottles in order to preserve their seasoning and medicinal qualities.

ANISE-An annual, cultivated principally for its seeds, which have a pleasant taste and smell. The leaves are also used for seasoning, garnishing and medicinal purposes. Packet 5c.

BENE (Sesame)-Hardy annual. Its rich, oily seed make oil nutty food for putting in bread, cakes, candie and sausage. Plant in waste places and woodland lots in spring. Each 5 -foot plant produces 30,000 seed. Greedily eaten by birds and poultry. Cattle do not eat the plant's foliage. Greatest known attracter and feeder of birds in fields, parks and game preserves. Its sudden bursting pods, parks and game preserves. Its suden bursting pods give the magician his "Open Sesame." Every farmer all waste places. Bene reseeds itself. This reseeding is a great help to those who plant it and who wish a return o it year after year. Our seed Southern grown. Imported seed rarely germinate, and come dwarf. America import yearly thousands of tons from China, Turkey and India. All ripening seed scatter. It is a pretty plant, growing five or six feet, and always looks fresh. It yields about 500 to 700 pounds per acre. It is grown just about like cotton and cultivated. It is the till or gingeli of British India and largely eaten as a food, especially in sweet meats. The poor even eat it after the expressage of the oil. Packet 5c; 4 ounces $20 \mathrm{c}$; pound $50 \mathrm{c}$ ! 5 pounds $40 \mathrm{c}$ per pound.

CATNIP, or CATMINT-A hardy perennial, well known as a valuable mild nervine for infants. Can be sown either in the fall or spring in drills 20 inches apart. Packet 5c.

CARAWAY-Cultivated for its seed, which is used in confectionery, cakes, etc. The leaves are sometimes used in soups. Sow either in spring or fall, but fall is the best. as the plants will give a large yield of seed the following season. Packet 5 c.
CORIANDER - A hardy annual, cultivated for its seed, which has an agreeable taste and is used in confectionery and to dissuise the taste of medicine. Gather on a dry day, bruising the stems and leaves as little as possible, for when injured they have a disagreeable odor which they impart to the seed. Packet 5 c.

DILL-An annual, cultivated for its seed, which has an aromatic odor and a warm, pungent taste. It is used for flavoring soups, stews and pickles, being particularly desirable for use in cucumber pickles, as it heightens the flavor. Packet $5 \mathrm{c}$.

SWEET FENNEL-A hardy perennial. Leaves largely used in soups, fish sauces, garnishes and salads. Packet 5c. HOREHOUND-A perennial herb largely used in making cough syrup and lozenges. Packet $5 \mathrm{c}$.

LAVENDER - A hardy perennial, used to make lavender water, or dried and used as a perfume for linens, etc. should be picked before it becomes dry. Packet 5c.

LEEK-The oblong bulk or stalk has the flavor of an onion, and is used principally in the winter for flavoring soups and stews. Packet 5c.

SAGE-One of the most popular perennial herbs, possessing some medicinal properties, but used principally for flavoring and stuffing sausages, being more extensively used for this purpose than any other herb. Packet 5c.

TANSY-For making bitters. Packet 5c.

THYME-A perennial, used both medicinally and for culinary purposes. Sow early in the spring. Packet $5 \mathrm{c}$.

\section{SPRING FLOWER SEED.}

“Practieal Gardening" -By Hunn \& Bailey, Cornell University. Standard edition. The most complete book published on flower gardening, and quite complete on vege table gardening. 250 pages. Let us mail you this book. Price $65 \mathrm{c}$ postpaid.

OUR ESPECIALLY SELECTED IIST OF FLOWER SEED, ADAPTED TO THIS LATITUDE, WHICH HAVE PROVEN SUCCESSFUL AFTER CAREFUL TESTS:

AGERATUM-Blooms all the summer; 2 feet; annual. Packet 5c.

ALYSSUM-(Sweet Mad Wort)-Pretty for vases; little plants. Packet 5c.

ASTER VICTORIA-(Mixed.) The best Aster; 18 ins.

Packet 5c.

BACHELOR'S BUTTON-(Corn Flower.) Packet 5c.

BALIOON VINE-(Love in a Puff.) Annual; climbing. Packet 5c. 
CALENDULA-(Pot, Marigold.) 1 foot. Packet 5 c. CALIOPSIS-2 feet. Packet 5c. 1 fot. Packet 50

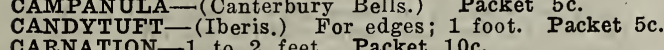

CARNATION-1 to 2 feet. Packet 10c.
COCKSCOMB-(Celosi.) Border plant and for pots. Packet 10c.

COSMOS-4 to 6 feet. July till frost. Packet 5c. CHINA PINK, or INDIAN PINK-Double and showy. Packet 5c.

CYPRESS VINE-(Ipomoea Cyclamen.) Climber; starshaped flower; 10 feet. Packet 5c.

DAISY BELLIS-Very popular; makes beautiful borders. Packet 10c.

DAISY SHASTA-Perennial, propagates by roots as well as seed. Flowers keep for two weeks; from 1 to 4 inches in diameter, 2 feet tall. Very handsome. Packet 10c.

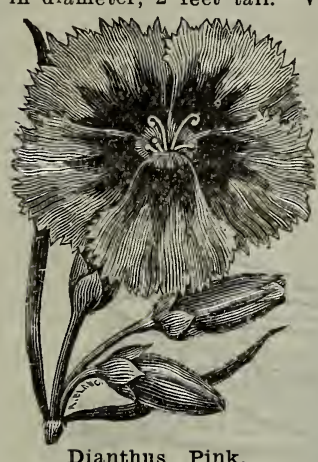
DIANTHUS, or PINKS-2 feet. Packet $5 c$.

D O L I C H O S-(Hyacinth Bean.) Annual climber; flowers freely; pretty seed pods: 10 to 50 feet. Packet $5 \mathrm{c}$

FORGET-ME-NOTS - (MYO sotis.) Little border; perennial, 6 to 10 inches. Packet $10 \mathrm{c}$. FOUR O'CLOCK- $\mathrm{Or}$ Marvel of Peru.) 2 feet. Packet $5 \mathrm{c}$.
FOX GLOVE, or DIGITALIS -Hardy; perennial. Packet $5 \mathrm{c}$ GAILLARDIA-Bouquets, or house decorations; 2 feet. Packet $5 c$.

GOLDEN GLOW-(Rubdeckia L. F. P.) Perennial; 8 feet: blooms July to September; deep yellow; effective for clumps or landscapes. Plant seed in early spring; also propagates by shoots. Packet seed 10c.

GOURDS-Mixed gourds. Packet $5 \mathrm{c}$.

HOLLYHOCK-(Athea Rosea.) Majestic; hardy; perennial. Packet 5c.

JAPANESE MORNING GLORY-(Imopeoa Imperialis.)

Climbing; handsomest of all Morning Glories. Packet 5c. LARKSPUR-Hardy, annual and showy. Packet 5c. MARIGOLD-(Tagetes.) Tall, hardy, annual, 1 to 3 feet. Packet $5 \mathrm{c}$.

MIGNONETTE-(Reseda.) Sow any time. Fragrant. Packet $5 \mathrm{c}$.

MOON FLOWER-(Ipomoea Grandiflora.) Climber, white flowers 5 to 6 inches diameter, fragrant evening. Pkt. 10c. NASTURTIUM-Dwarf or Tall; one of best annuals and the most popular of all flowers. Easy culture. Assorted colors. Packet 5c; ounce 20c; pound $\$ 1.25$.

PERIWINKLE-(Vinca.) Summer garden, winter house, 2 feet; large pink and white. Packet 5c.

PETUNIA-Blooms early summer till frost. Effective, $1 \frac{1}{2}$ to 2 feet. Packet 5c.

PHLOX DRUMMONDI-(Flame Flower.) Brilliant summer flowering annual; 1 foot. Packet 5c.

PORTULACA - (Moss Rose.) For edging or rock work; thrives anywhere; $11 / 2$ feet. Packet $5 \mathrm{c}$.
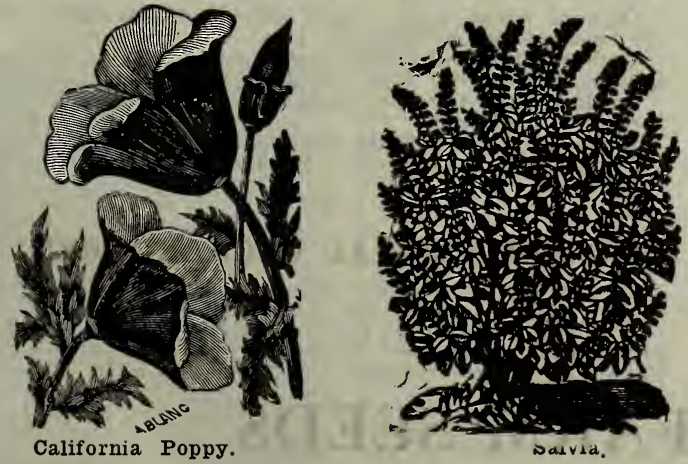

California Poppy.

POPPY-(California Single.) Desirable, wide color range,

2 to 3 feet. Packet $5 \mathrm{c}$.

POPPY - (Extra Large Double.) All colors; usual growth

3 to 5 feet. Packet $5 \mathrm{c}$.

PANSY - The world's favorite; perennial; sow August and September. Packet 10c.

RICINUS-(Castor Oil Bean.) Ornamental leaved; annual; 8 to 10 feet. Packet 5c.

SALVIA- SPLENDENS-(Flowering Sage.) Perennial; scarlet; 3 feet. Packet $10 \mathrm{c}$.

SUNFLOWER-CHRYSANTHEMUM-Flower double; tall, 7 feet; large yellow flowers, look like Chrysanthemums, new. Packet 5c.

SUNFLOWER-RUSSIAN-8 to $10 \mathrm{ft}$, large. Pkt. $5 \mathrm{c}$.
SWEET PEAS- (Willet's Special Mixed.) The very best mixture possible to obtain packet 5 $30 \mathrm{c}$; pound $\$ 1.00$.

SWEET PEASStraight varieties, which are specially which are specially
selected according to results they hav given after careful testing. Emily Henderson (early white). Blanche Burpee (extra large white); and white); Apple and white); Apple plossom ( b r i g h t cy (pink, light at edges); King Edward (scarlet); Captain of the Blues (bright blue and purple); Countess Randor (light blue and lavender); E $\mathrm{m}$ i $1 \mathrm{y}$ Eckford (delicate lavender); Hon. Mrs. $\mathrm{K}$ en y o n (primrose yellow); A merica (striped white and pink). All above

Sweet Peas price at:

.

VERBE

WALI FLOWER-Perennial. Packet 5c.

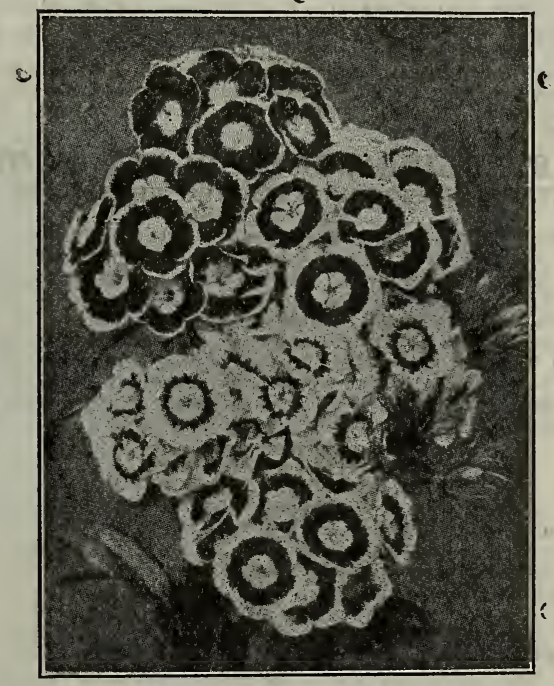

Sweet William.

SWEET WILLIAM-(Dianthus, Barathus.) Hardy pa ennial. 1 foot. Packet 5c.

WILD CUCUMBER VINE-The newest and best additis to climbers. Packet $10 \mathrm{c}$.

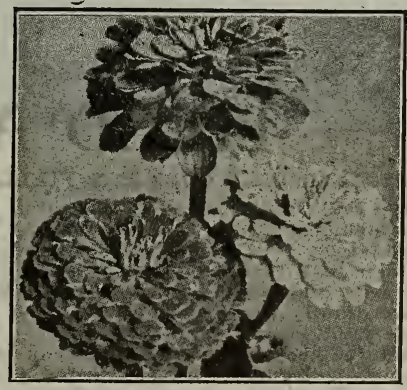

Zinnta.

ZINNIA-(Double.) Resembles Dahlias. Packet 5c. 
WILLET'S FLOWERING BULBS.

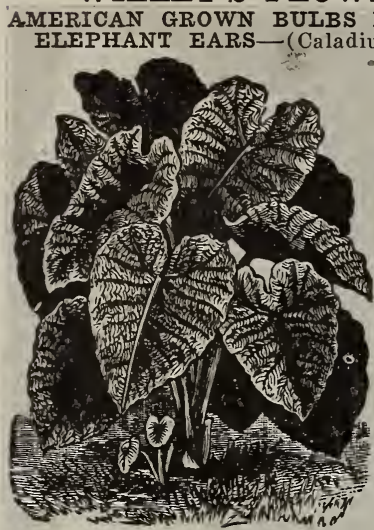

Elephant Ears. dozen $\$ 1.00$. for $\$ 1.50$. $75 \mathrm{c}$.

\section{FOR SPRING PLANTING.} early spring. 10c each; 1

DAHLIAS-Plant early spring until middle of summer; all leading va-
rieties, $15 \mathrm{c}$ each; 4 for rieties, 15c each; 4

GLADIOLI-Plant early spring and summer. 4 for $20 \mathrm{c}$; dozen for $50 \mathrm{c}$;

CANNAS - Plant early spring and summer. All colors. Each 10c; dozen

TUBE ROSES-Plant in early spring. 1 dozen $25 \mathrm{c}$ 25 for $40 \mathrm{c} ; 100$, $\$ 1.50$. For prices and descrip-
tion of all bulbs for fall planting, such as Hyacinths, Narcissus, Tulips, EVERGREFN LAWN GRASS.

Willet's Evergreen Lawn Grass forms a rich, deep, green, velvety lawn in a few weeks' time. Composed of various grasses that grow and flourish during different months of the year, so that witl proper care and attention, a beautithe year, so that with proper care and attention, a beautiused are those which years of experience have shown to succeed and do best in our Southern soils and climate. Sow at the rate of 60 pounds per acre, or for small yards, one pound to $10 \times 10$ feet. - Can be sown either in the spring or fall. When sown in the spring it should be put in early, although it can be satisfactorily seeded as late as April. Do not use stable manure-makes weeds and misceilaneous grasses. Use especially prepared fertilizers as listed below. Price, 1 pound $35 \mathrm{c} ; 5$ to 10 pounds $30 \mathrm{c} ; 25$ to 50 pounds $25 \mathrm{c}$.

\section{STERLINGWORTH PLANT FOOD.}

CONTAINS NITROGEN, AMMONIA, PHOSPHORIC ACID AND POTASH.

Takes place of liquid manure. Starts plants at once into healthy and vigorous growth, and makes them grow and bloom luxuriantly. These tablets drive troublesome insects and worms from the soil. They are odorless, nonpoisonous, uninjurious, and are clean and easy to handle. poisonous, uninjurious, and are clean and easy to handle. Food Tablets, and see how quickly they are benefited. Trial size box, sufficient for 10 house plants for 3 months, 10c, postpaid. Large size box, sufficient for 35 plants for 3 months, 25c, postpaid.

\section{FERTILIZERS.}

\section{FOR FLOWERS, LAWNS, ETC.}

The Fertilizers listed below are specially recommended for Flowers, Lawns, etc.:

Pulverized Sheep Manuire 100 lbs. $\$ 3.00$ Pulverized Sheep Manume $-1 \mathrm{~b}$ - cartons, each, 40c; $10-1 \mathrm{~b}$. cartons, each, 65c.

Pulverized Cow Manure.............................100 lbs. 2.50 Bone Meal, $1 \mathrm{lb} .10 \mathrm{c}$ Ladco Ground Limestone-We are Augusta Agents for this best of all Ground Limestone; used for sourness or acidity of land, and now being used in tremendous, amounts in our light soils, clay soils and in our swamp lands. Sold only $f .0$. b. mine North Georgia, car lots loose (35 tons), at $\$ 3.75$ per ton.

EARTHENWARE FLOWER POTS.

$$
\begin{array}{cr}
\text { 4-inch 5c } & 5 \text {-inch 7c } \\
6 \text {-inch 10c } & 7 \text {-inch } 12 \mathrm{c} \\
\text { 8-inch 15c } & 10 \text {-inch 35c } \\
12 \text {-inch 70c } & 14 \text {-inch } 1.15 \\
\text { each. Dozen lots deduct } 10 \%
\end{array}
$$

\section{FIELD AND}

AMERICAN INDIAN CORN FOR FIELD SEED.

Make 1919 the greatest of all Corn years! No man who makes an abundance of Corn, Oats, Wheat, Velvet Beans, Peanuts and Hogs, will find himself at winter's time in any other than good condition. Make early corn plantings. Also follow oats and wheat with corn (for June plantings use Mexican June), thus making two good money crops on the same land in the year.

By the side of every corn stalk, plant in late spring, or early summer, a legume-Velvet Beans, Cow Peas, Soy Beans, Beggar Weed-for turning under; also peanuts in corn make a good money crop. Where the above legumes are turned under follow in fall, 1919, with grains and use no guano, save acid phosphate:

\section{LAWN MOWERS.}

Anyone wanting a Lawn Mower will find it cheaper in the end to buy the best. While we offer cheap Lawn Mowers, we advise all of our customers to buy the Pennsylvania or the Great American. These will last a lifetime, with a little care. If parts wear out these can be replaced at small cost and the machine be as good as new, while the cheaper mowers take more time to replace broken parts and get in condition than to buy a new machine.

Red Bird-Wheel $7 \frac{1}{2}$ inches, blade 14 inches........\$ 5.50 Pennsylvania Plain Bearıng-8-inch wheel, 4 blades blades 16 inches Be..............

Pennsylvania Ball Bearing-101/2-inch wheel, 5

blades 15 inches....................................... 15.00

Pennsylvania Ball Bearing-10 1/2-inch wheel, 5
blades 17 inches

Great American Ball Bearing-101/2-inch wheel, 5

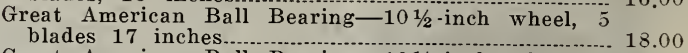
Great American Ball Bearing-10 1/2-inch wheel, 5 blades 19 inches............................................... 200

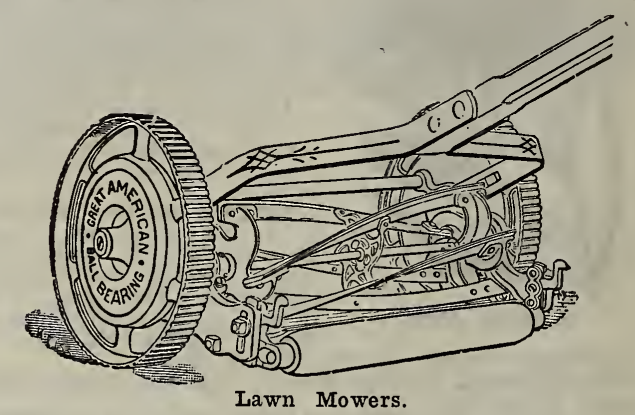

Grass Catchers-15 inches

17 inches 15 inches.............................................

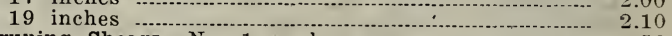

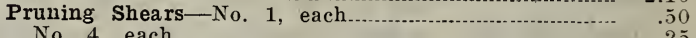

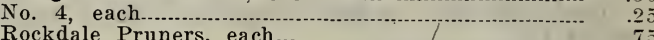

Rockdale Pruners, each

Rubber Hose for Lawn sprinkling-Best grade $3 / 4$-inch in 25 -foot lengths at 15 cents a foot.

SPRAY NOZZLES AND SPRINKLERS.

"Just Right" Spray Nozzles, each........ $\$ 0.60$

"Shower Bath" Spray Nozzles, each.

"Rainfall" Spray Sprinklers (new), each..................

"'Zenith" Sprinklers, each (new), each............... 1.2.

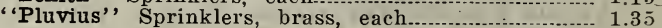

\section{OUR FRUIT INDUSTRY DEPARTIMENT.}

Orchard fruits, small fruits, shrubs, ornamentals. Te are agents here for wholesale growers of the following:

Orchard Fruits--Peaches, Apples,' Pears, Plums, Cherries, Quinces, Mulberries, Figs, Japanese Persimmons, etc.

Small Fruits-Currants, Raspberries, Blackberries, Dewberries, Grapes, etc.

Nuts-Pecans, Black Walnut, English Walnut, etc.

Ornamentals-Evergreens, Privets, Roses, Flowering Shrubs etc.

\section{TO COMIMERCIAL ORCHARD MEN!}

In 500 to 1,000 lots we can give you lowest prices-our grower being wholesale, and exclusively peaches.

NOTE!-This above Fruit Industry Department has grown to be a large and interesting one to us, and a prof itable one to our customers. Tell us your wants.

\section{FARM SEEDS}

Our seed Corn-We do not handle corn from higher latitudes-North or West-except. where extreme earliness in the crop is desired. Our sales of varied types of corn are confined almost exclusively to tCorn that is Southern grown, and from the best localities brought to us in carload lots from the original growers. The danger sometimes of feeding Western corn has enhanced the value of Southern corn. Southern corn is never pulled until fully mature on the stalk, is far dryer and carries better eating and feeding qualities and should bring some premium over Western corn.

Quality of Willet's Corn Seed-We sell thousands of bushels of Corn Séed. We have better and finer seed than ever before offered. We have, besides, the finest electric 
cleaning machines for our grains. Many thousands sell Corn for seed" ; only the few sell "Corn Seed."

Bisulphide of Carbon-For the keeping of corn, peas and all grains in barns and warehouses-an insecticide, too, for weevil-infested cotton-Pound 60c; 5-pound can for $\$ 2.50$. For grain, pour directly into the mass in several places, allowing 15 pounds to each 1,000 bushels. Cover places, allowing 15 pounds to each 1,000 bushels., Cover pound saves $1 / 2$ ton of seed. For weevils and any insects in grain that is to be stored away. Use in tight closed corn crib, in keeping corn 1 pound to 70 bushels of corn. Explosire; keep fire and pipes away. Can't be shipped by mail-express only.

Culture-Plant 6 quarts to acre. Usually planted in the South from March 5 th to June 25 th. Our best growers around Augusta are making now uniformly 40 bushels or more to the acre. Plant 5-foot rows 12 inches in drillthough controlled by strength of land. A good fertilizer consists of 250 pounds Acid Phosphate and 250 pounds cotton seed meal per acre. Never plow corn deep. Plant field corn in Florida January and February. We warn farmers against planting seed corn taken from fodderpulled stalks-such seed may decrease next corn crop by 10 to 15 per cent. We warn the farmer, too, against fodder pulling; it decreases quantity of corn in pounds, decreases chemical and feeding qualities, and causes 10 per cent of corn to rot.

EARLY DENT CORNS -Our Early Dent Corns are from the best habitats for this corn. Dents are called Hundred-Day Corns. For early farm corn, noth ing takes the place of the Dents. They come on for the farmer in the nick of time for feeding (or meal) 100 days from planting. The Dent Corns are not only used for Early, but also for Midsum mer, plantings.

WIILET'S IMPROVED GOLDEN DENT-The type GOLDEN DENT-The type ever before offered, ears are especially large, grains large, wide, deep and of deep, yellow color. The most valuable Yellow Corn today known. Our earliest field corn. Meal can be had from it about $\mathrm{Au}$ gust 15th. The sowing of Dent Corn increases each year. We offer especially large stocks this year of Improred Yellow Dent Corn. Its earliness makes it invaluable. Buy fresh seed each year. The Dent Corn grains are a trifle Willet's Improved Golden Dent. softer than many other

Corns.. One quat $30 \mathrm{c}$; peck $\$ 1.30$; bushel $\$ 4.25$; sack, $2 \frac{1}{2}$ bushels, $\$ 4.00$ per bushel.

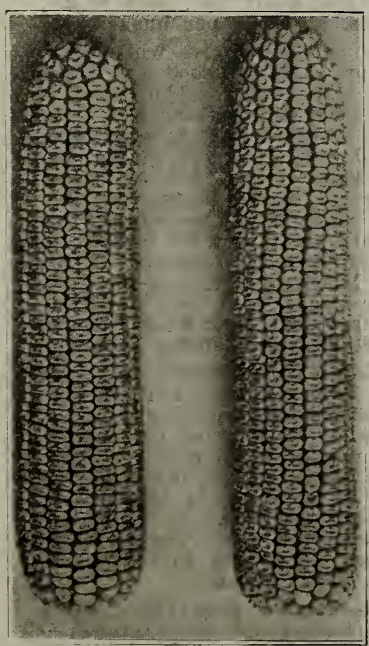

IMPROVED W H I T E DENT-Along with our extra heavy and choice stock of improved Yellow Dent, we are offering the heaviest stocks of a choice variety of selected White Dent this year. This is the main crop for feeding purposes grown in Virginia; oftentimes 60 to 90 bushels on good land, very large grain.

This corn is similar in every way to the Yellow Dent, except the grain is white. Some prefer this on account of the meal. One quart $30 \mathrm{c}$; peck $\$ 1.25$ bushel $\$ 4.10$; sack, $2 \frac{1}{2}$ bushels, $\$ 3.90$

WILLET'S PROLIFIC GOLDEN BEAUTY CORN -New and listed only by us. We have produced this corn through many years of crossing the Louisiana Yellow Creole, Marlboro and Georgia SixEar. The product is the best yellow corns in the South today, and the most Willet's Improved White Dent. corn, color of the richest yellow, ears a little larger than Georgia Six-Ear; very sim ilar to Marlboro. Very hard and prolific; very resistant to drought and almost weevilproof. Is very high in feed value. Grower claims will feed longer than any white variety. mand for a number of years for a hard, yellow prolific corn. We think we have succeeded in producing this and now offer same to the trade. Have only a limited amount of this variety to offer. Price, 1 quart $30 \mathrm{c}$; peck $\$ 1.35$; bushel $\$ 4.50$; $2 \frac{1}{2}$ bushels at $\$ 4.25$ bushel.

GARRICK-A white corn now supplanting Marlboro in South Carolina, and winning most of the farmers' corn prizes. (South Carolina today being the most advertised corngrowing state in the United States.) Has won more contests in South Carolina than any other Corn. One grower in S. C, got 500 bushels on five acres. Young Usher, of South Carolina, who won the South Carolina premium, and Willet's Golden Beauty. was given a trip by U. S Agricultural Department to Washington, D. C., free, planted Garrick. An Augusta grower made without any special cultivation, 700 bushels on 12 acres last year; another grower in 7 -foot rows and 12 inches to the row made 65 bushels per acre, and another good crop as a subsidiary crop in between the rows. Two to five ears. Stands drought. Planted after cucumbers here this past year, 25 acres made 1,500. bushels. One quart $25 \mathrm{c}$; peck $\$ 1.25$; bushel $\$ 4.10$; sack, $2 \frac{1}{2}$ bushels, at $\$ 3.90$ per bushel.

WILLET'S WHITE WEEVIL-PROOF PROLIFIC CORN -New and only listed by us. Agricultural Department, Washington, has been working for a number of years on a

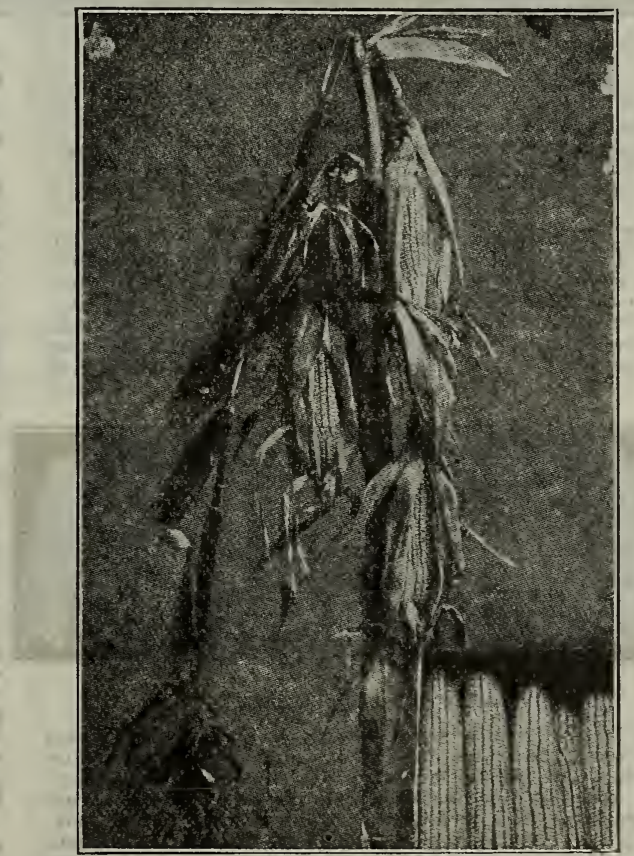

Willet's Weevil-Proof Corn

white weeril-prof corn They first tried to get a haro resistant corn; this failed. Second, to get a thick, heavy long shuck, to completely cover the small; often open end of the ear where the weevils enter, and many other insects attack the corn. They have succeeded in this, and it has proved a tremendous success against weevils. The corn (named above) now allows the growing of corn where weevils have largely heretofore made it impossible. This corn has a small ear, size of Marlboro; a red cob; grains long. Very prolific. We have only about 500 bushels of this new weevil-proof corn to offer. A weevil-proof corn has long weevil-proof corn to offer. A weevil-proof corn has long
been wanted, especially for South Georgia and Florida. 
An Augusta big corn grower says: "Not large stalks. Shucks long and cover ends. About three ears to stalk. Most prolific corn I ever raised." Shucks that extend besilks are weevil-proof, both in field and storage. (All other corn before storing had better be shucked.) Price 1 quart $30 \mathrm{c}$; peck $\$ 1.35 ;$ bushel $\$ 4.50 ; 2 \frac{1}{2}$ bushels at $\$ 4.25$ per bushel.

THOROUGHBRED BIG ROCKDALE CORN-Our grower has been breeding for eighteen years this corn out of big eared Shaw. He has now a big improvement over Shaw. It is among all the big-eared corns the modern "thoroughbred." Ears are about 12 inches long with large 'diameter. Grains white and big and fill out the extreme tip end (tong Grains white and big and fill out the extreme tip end (tong
shuck). Ears often $11 / 4$ pounds. Hardy, flinty grain. The shuck). Ears often $11 / 4$ pounds. Hardy, flinty grain. The ideal corn on rich bottom land in Georgia or black lands of
Southwest. Have seen one ear shell out one quart. Very prolific. An amazing corn. Price, 1 quart 25c; 1 peck $\$ 1.25$; bushel $\$ 4.10$; sack, $2 \frac{1}{2}$ bushels, at $\$ 3.90$ per bushel.

WILLET'S IMPROVED MARLBORO PROLIFIC-We have increased the size of grain. A beautiful white prolific
corn. Medium early, well adapted field purposes, just flinty enough for milling most beautiful hominy and meal. From practical experience and field test-out, Marlboro Pro-

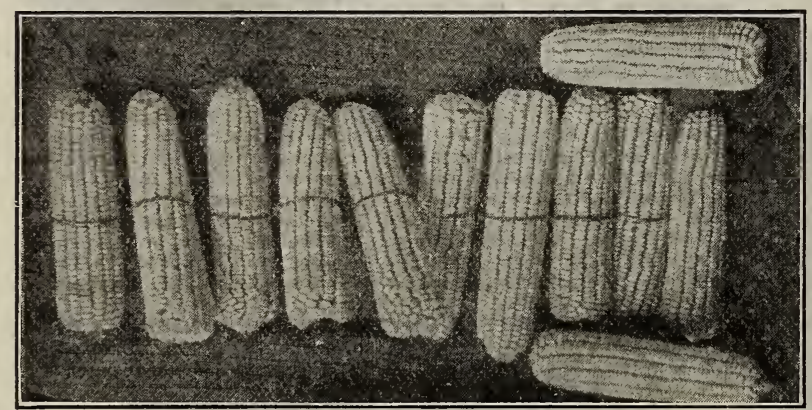

Willet's Marlboro Corn.

lific is one of the best of all prolific varieties; yields often from 2 to 4 ears to each stalk. Some of the largest yields of corn ever made in South Carolina were made from Marlboro, and it has probably won many large premiums. Grains and ears are some larger than Cockes. Quart 25c; peck $\$ 1.25$; bushel $\$ 4.10$; sack, $2 \frac{1}{2}$ bushels, at $\$ 3.90$ per bushel.

WHATLEY'S PROLIFIC CORN-New. Agricultural College at Athens for three years test in succession makes this corn to lead all. One of the prolific, many-eared corns. Runs two to three ears to stalk, and seemingly an improvement over all. Ready for milling ten days to two weeks before the Six-Ear corns. Has a larger stalk which grows off quicker and has a deeper root system and withstands
drought better. Ears are 5 to 8 inches long, grains,

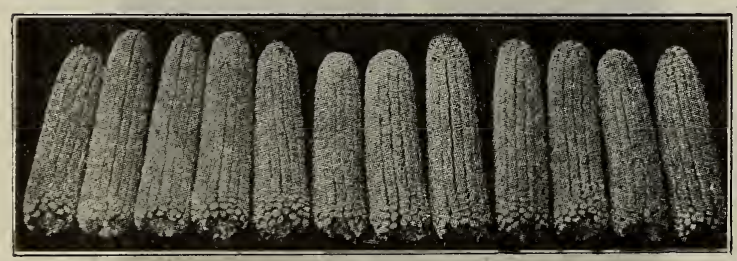

Whatley's Prolific Corn.

5-8-inch long, 3-8 inch wide, hardy, creamy white. Makes unsurpassed meal. Cob dark red. More prolific than SixEar corns. Grains are cream white, not flint; fine meal. Augusta truckers, beginning its marketing about August 5 th for roasting ears, a veraged 3 ears to stalk. Good root shells easily. We average 65 bushels. A great Augusta favorite. Made Augusta, 1918, 75 bushels per acre, averaged 3 ears to stalk. Ears bigger than Six-Ear Corn.
Price, quart 25c; peck $\$ 1.25$; bushel $\$ 4.10$; sack, $21 / 2$ bushels, at $\$ 3.90$.

MOSBY PROLIFIC CORN-Adapted to all soils. Early. Favorite in Miss and Ala. One to 2 big ears-8 $1 / 2$ to inches, 14 to 16 rows. - Weight ear about $14 \mathrm{oz}$. Small cob. Shelling perfect. A refined corn, making a maximum of grain with minimum of waste growth. Kernels white. $\$ 1.25$; bushel $\$ 4.10$; sack, $2 \frac{1}{2}$ bushels, at $\$ 3.90$ bushel.

WILLET'S PRIDE-This corn has been grown for the

past ten or fifteen year's in this vicinity. It is one of the best field corns wa have ever listed. Quite a number of growers call it poor land corn. Is a wonderful corn, stands more drought and adverse seasons than any we have ever tried. Extra deep, long grains; medium sized ear, very small red cob. Our grower the past season averaged 47 bushels per acre on his entire crop. One grower near $\mathrm{Au}$ gusta averaged 70 bushels on ten acres. We can recom. mend this corn to any farmer. Price, 1 quart $25 \mathrm{c}$; peck $\$ 1.25$; bushel $\$ 4.10$; sack, $2 \frac{1}{2}$ bushels, at $\$ 3.90$ bushel.

COCKE'S PROLIFIC-Flinty white, heavy. Stood highest test at Georgia Experimental Station. Our breeder has made a specialty of this corn for 10 years. He has increased its usual length of grain, set its habits to 2 ears, increased the width of the blade, and reduced the height of the stalks, which makes it a more desirable corn than the usual Cocke's Prolific. Out of 32 varieties N. C. Exp. Sta. for eight years ranked as having the highest a verage. It averages about 175 ears for 100 plants. Nothing better for ensilage. In Virginia grows 15 feet, often, or four ears to stalk; grains are flinty and glisten like silver; medium cob, large ear. Cocke's is considered one of the most bushel $\$ 4,10$; sack, $2 \frac{1}{1 / 2}$ bushels, at $\$ 3.90$ per bushel.

GEORGIA SIX-EAR-This corn is sold elsewhere under numerous names. Average length of ear 7 inches. In one lot, 20 acres, in North Carolina, not a stalk furnished less than three ears. Twenty acres produced 2,041 bushels, averaging 127 bushels to the acre. Largely grown about Augusta, and one of our most productive varieties, small ears and cob, long grains. A prize-grower 1918 got 102 bushels from one acre. White fint corn. Turns out remarkably well when shelled. Ears filled to the end. A most excellent shelled. Ears filled to the end. A most excellent
keeper. One grower from our seed this year made 1,000 bushels. The cob is absolutely insignificant. An Augusta grower made on 22 acres 98 bushels of corn per acre. One grower in South Carolina, on three acres of Six-Ear corn, made actual weight 116 bushels to the acre. Horses like it more than other corn. One quart $25 \mathrm{c}$; peck $\$ 1.25$; bushel $\$ 4.10$; sack, $21 / 2$ bushels, at $\$ 3.90$ per bushel.

SHAW'S IMPROVED-One of the largest eared corns grown. Ears average from 9 to 12 inches long, 16 to 20 rows, deeply set from butt to tip, grains white and almost perfect in shape. Shelling 85 per cent. The stalk is large, very strong and storm-resistant owing to its large rooting. Heavy in foliage, with generally two good ears. One of the most popular big-eared generally two good ears. One of the most popular big-eared corns planted today, having an average yield of about 80
bushels per acre. Quart 25c; peck $\$ 1.30$; bushel $\$ 4.25$; sack, $2 \frac{1}{2}$ bushels, at $\$ 4.00$ per bushel.

RED COB-The great Tennessee corn; known in Virginia as "Columbia Beauty"; large ears; medium early. rginia and Tennessee. A large white grain not flint, medium red cob. Largely used in sandy soil, and in the swamp. Almost drought-resistant. Has made 20 bushels in this county in sandy soil where other corns made 10. The best all purpose corn, and adapted to all lands that grow corn. This corn is the principal corn grown in the renowned corn lands in Orangeburg and Barnwell Counties in South Carolina-called, though, sometimes by other names than Red Cob. It is a prime favorite in all the coast counties in South Carolina. Can be planted March to July at Augusta. Ninety ears of this corn at Augusta weighed 79 pounds, which corn was made without guano. One quart $25 \mathrm{c}$; peck $\$ 1.25$; corn was made without guano. One quart $25 \mathrm{c} ;$ peck $\$ 1$
bushel $\$ 4.10$; sack, $2 \frac{1}{2}$ bushels, at $\$ 3.90$ per bushel.

HICKORY KING-A popular and productive white corn, especially for high land. It produces on good soil three or four averaged sized ears to the stalk. The grain is large, very broad and beautifully white, making the finest quality meal. The cob is of ten so small that a large sized grain will cover the end of it The biggest grains and the smallest cob of all corns. Matures in 115 to 125 days. Fine cornmeal corn. One Augusta farmer claims the past season from our seed to have made 2,000 bushels of this corn $_{2}$ and on some parts of his plantation 80 bushels to the acre. In Virginia, Hickory King is regarded as the best poor land corn. Down in Mississippi, on the contrary, no other corn in the rich lowlands has been found so productive and useful. One quart $25 \mathrm{c}$; peck $\$ 1.25$; bushel $\$ 4.10$; sack, $2 \frac{1 / 2}{2}$ bushels, at $\$ 3.90$ per bushel.

VIRGINIA ENSILAGE-Makes a larger growth and more fodder than other sorts. The universal Ensilage and fodder corn. A great Virginia favorite for corn and fodder. Known in Virginia as Eureka. Aside from its magnifi14 inches, and on rich land in Virginia it grows 12 to 16 feet high. It has been known to produce 142 bushels per feet high. It has been known to produce 142 bushels per acre. Often grows here 15 feet. Big white ears. A tall remarkable silo corn; largely exported to Germany. Yields $\$ 4.00$; sack, $21 / 2$ bushels, at $\$ 3.75$ per bushel.

BRAZILIAN FLOUR CORN-Grains good size. Stalk tall, 10 to 15 feet high, wide blades and quick grower80 to 90 days. Plant early or till July 10th. Used largely for roasting ears, for flour grinding, and for barn use, too. 
wheat. Each grain sends forth three or more stalks, main stalk has three ears and other stalks one or two. A wonderful yielder, The earliest of all corns. Fairly good roasting ears. Makes best meal of all corns. Grain dent in it. There is no hard part at all to the graingrain is all soft and can be chewed up like wheat. A most useful corn, but little known here. Price, quart $45 \mathrm{c}$; peck $\$ 2.00 ;$ bushel $\$ 7.00$.

MEXICAN JUNE CORN-(Georgia grown, see cut.)We sell only the tall, not the dwarf-the dwarf being a mixed corn. Grains silvery white and soft. Plant not before June ist and up to July 15 th. Grows 12 to 15 feet fore June 1st and up to July 15th. Grows 12 to 15 feet can be planted so late, nor grow so tall, nor make such an can be planted so late, nor grow so tall, nor make such an
amount of late forage. You can have roasting ears September till frost, while remaining stalks give fine green

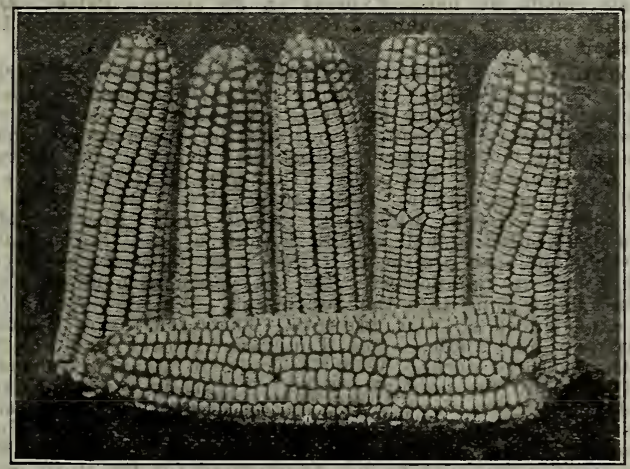

Mexican June Corn.

forage for cattle. Pull in December. Till then does not harden on stalks-keeps green and soft. The planted as late as July 15th and matured before frost, made 65 bushels to the acre. Our crop this year was planted June 16th. Yielded 65 bushels to the acre. A party here last year planted 1st of June, eight acres on rock land, Tall Mexican June Corn; on three acres he got 130 bushels shelled corn, and he put the five acres into silo, which after settling, etc, made 90 tons net silage, thus reaping 16 -tons silage per acre. Cultivated three times. Gathered about Norember 2 oth. A customer who has been growing 100 acres in Mexican June for seren years, says: "I plant as late as August and of ten hare roasting ears as late as De-
cember. Mexican June, giving a fine corn grain crop and a fin forage crop besides. Oftentimes perfectly green middle of November. We have improved the quality of our corn to the place where it will produce two large ears to the stalk, and each ear averaging frum 600 to 700 grains. Never pull the fodder. The cob is sappy; let it remain on the corn stalk until December. A safer corn planted after spring gathered grains than is other corn. Will stand drought. Made good hard corn here this year planted July 30 th. Quart 30c; peck $\$ 1.35$; bushel $\$ 4.25$; sack, $21 / 2$ bushels, $\$ 4.00$ per bushel.

\section{POP CORN}

WHITE RICE-This is probably the most popular of all pop corns. It pops pure white; the quality is excellent. $18 \mathrm{c} ; 100 \mathrm{lbs}$, at $16 \mathrm{c}$ per lb.

GOIDEN QUEEN-A large-eared and handsome yellow grains are large, pop perfectly. white and are exceedingly tender. About 6 feet high and yields three or four ears. Packet $5 \mathrm{c} ; 1 \mathrm{lb}$. $25 \mathrm{c} ; 5$ to $10 \mathrm{lbs}$, at $20 \mathrm{c} ; 25$ to $50 \mathrm{lbs}$. at $18 \mathrm{c} ; 100 \mathrm{lbs}$. at $16 \mathrm{c}$ per $\mathrm{lb}$.

POP GORN FCRAGE-Pop corn is usually thought of as only a "'popping", proposition, but it is, however one, of the best combination spring forages known. Earlier than oth.cr corns for forage, and is usually planted in three or four-foot rows, about six inches in the row, several grains to the hill. In June it is full grown, and has an abundance of ears of corn in the milk. It is marrelous to know the amount of forage that such a field planted in pop corn will make. Can plant up to July 4th. Stools heavily. The grain, corn and fodder make a perfect ration. Plant one peck to $1 / 2$ bushel per acre.

POP CORN AND COW PEAS MIXED-Mix one-fourth pop corn and three-fourths peas. The best and cheapest hay. Plant with pea planter. Gather when the corn is in the ear. Makes balanced ration. Cures more easily than peas with sorghum. Get prices.

BROOM CORN-Improved Evergreen. Grows about 8 feet high, stands up well. Free from crooked brush. Fibre long and fine. Will not get red in the field before it is cut. Strictly a green variety of •brush. One acre produces about 500 pounds of brush, and 30 or 40 bushels of seed. Plant in the spring like corn, the same cultivation, though somewhat later in the season. A tremendous crop in the TVest. Plant in drills $31 / 2$ feet apart, leaving six inches in the row, 20 pounds to the acre. Get Agricultural Depart. the row, 20 pounds to the acre. Get Agricultural Department at Washington to mail you a complete bulletin for preparation for the market. This crop has been tremen$25 \mathrm{c} ; 10$ pounds at $20 \mathrm{c} ; 100$ pounds at $18 \mathrm{c}$ per pound.

\section{High-Bred Cotton Seed}

\section{The Leading Early Types of Cotton Grown in the South Today and Description of Each \\ Ask for Carload Wholesale Prices.}

\section{IN COTTON SEED FOR PLANTING PURPOSES WE ARE LEADERS.}

WIITET'S EARIY COTTON SEED FOR BOLI WEEVIT STATES.

(Free of Boll Weevil.)

FUMIGATED COTTON SEED-As an extra precaution against boll weevil, and to make it absolutely safe, we are fumigating in the most approved and scientific manner, each sack of cotton seed as sent out by us into all noninfected territory. Each bag will carry the tag from our Ga. Entomological Department, showing said fumigation.

HIGH SPRING PRICES-Prices for oil mill seed in the South having been fixed by the Government there is no incentive for the farmer to hold tis seed as a speculative matter. It is to be feared that this will leave no Planting Cotton Seeds for Spring planting! Buy of us, then, your Planting Cotton Seed, now! High prices of seed, too, will bring great temptation to sellers to send out for planting seed ordinary mill seed.

THE BOLL WEEVII MAN'S safety is in the planting only of 90 and 100-day Cotton Seed. We specialize in Early and Anti-Boll Weevil Cotton, car lots (wire for price), and less, without which cotton lint would fetch today 50 cents a pound, and the world would be half naked! We are largest shippers-export and home use- of varied type cotton seeds in the United States. We list 25 types.

We are responsible, skilled, scientific cotton seed experts of 25 years' experience. and are not the usual and now so common, commercial cotton planting seed shippers. We are weil known in Boll Weeril areas and by the varied foreign gorernments now growing cotton Our seed are doubly attested" '- the grower's and ours.

QUALITY CF CUR COTTON SEEDS- Te buy our seeds of originators, or from scientific growers from seed bought rom originators, in carload lots. We know our growers; we know what is genuine seed of each type. When you buy of farmers or miscellaneous shippers you have no guarantee whatever. Our Planting Seed come almost exclusirely from the States of S. C. and N. C., from the finest Cotton Specialists and Cotton Planting originators in the South. We sell sacked, 30 pounds to the bushel; Sea Island 42 pounds; 1,000 bushels to the car; at the same points 1,200 bushels constitute a car. Wire for car lots delivered $\mathrm{f}$. o. b. you acked.

OUR COTTON PLANT CUTS-Our cuts are $\mathrm{n}$ t misleading, abnormal pictures made from plants on highly fertilized land, grown in 4-foot trenches, manured up to the top and plants watered. Our cuts are the normal plants on arerage land.

AN OUTRAGE, AND A WARNING-Hundreds of cars of supposedly "early cottonseed" have been sold in the past in the boll weevil districts by shippers who have used miscellaneous scrub stock bought from the oil mills. We also warn against much of the miscellaneous farmers' seeds of unknown types as advertised in the agricultural papers, grown by unscientific growers, uninformed as to what constitutes true type, and who are ignorant of the absolute heredity of their own seed. It is better always to come to scientific growers and shippers. 


\section{Varieties We Recommend for Boll Weevil States.}

EARIY SMALI, AND MEDIUM BOLI VARIETIESWillet's Perfection Early Cotton, Kings, Simpkins, Toole, Hites, Broadwell Double-Jointed, Money-Maker, CovingtonToole, Council Toole, Bates, Sawyer.

EARLY BIG BOLL VARIETIES-Express, Willet's Ideal Big Boll, Triumph, Cleveland, Rowden, Mexican Big Boll, Long Shank.

EARIY LONG STAPLE VARIETIES-Webber 49, Durango 1 1-4, Webber 821 1-4, Hartsville No. 111 1-4, Express 1 1-8, Dix-Afifi Wilt-Resistant 1 1-4, Keenan 1 1-4inch.

WILT-RESISTANTS-Dix-Afifi 1 1-4, Lewis No, 63 7-8inch, Council Toole 7-8-inch, Covington-Toole 7-8-inch.

BOLL WEEVIL NOTES-Plant above cottons early. Plant only cottons that set fruit early and rapidly and mature them quickly.

Write Clemson Agl. College, Clemson, S. C., for Prep. Bulletin 164, Mexican Boll Weevil and Regulations. Boll weevils prevented the production of about $2,000,000$ bales of cotton of 500 pounds gross weight and 970,000 tons of cotton seed in 1916 .

COTTON DISEASES-For "Red Spider"-lime sulphur or potassium sulphid; for "Mexican Boll Weevil"-calcium arsenate. See Insecticide page.

COTTON SEED TESTING-A test for germination is to cut the seed with a knife and examine and taste the kernel; if same is yellowish gray and tastes mealy and oily, seed is good. Always test your seed.

COTTON CULTURE-Break 8 or 10 inches deep with 2 -horse plow, and harrow with smoothing harrow; plant with corn planter; rows $3 \frac{1 / 4}{4}$ to 4 feet apart. Chop out
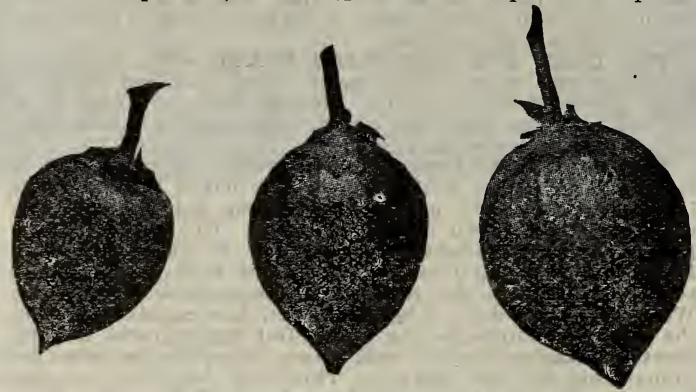

Small, Medium and Big Boll.

when cotton is up, spacing in rows 14 to 20 inches apart when cotton is up, spacing in rows 14 to 20 inches apart
in the drill, 1 or 2 plants to the hill, according to the land. in the drill, 1 or 2 plants to the hill, according to the land.
Some plant 18 inches in drill, 2 to hill. The "close spacing" plan is now largely used for early cottons in single stalk, 8 to 12 inches in row-hedge row fashion. Cultivate with cultivator shallow and level, about every 10 days, breaking crust and leaving a dust mulch to retard loss of moisture. Do not disturb roots. Manure on side late in season. Give wide spacing to long staples.

SYNONYMS-There are perhaps 25 cotton types standard (see this catalog). These cottons sail around in agricultural journals and elsewhere under thousands of names. Beware of synonyms or the alias. It is always a deception, and most often a fraud

"CAROLINA COTTON GRADER",-Eliminate in cotton seed all black and runty and lightweight seeds-thus increasing the cotton crop about 10 per cent, and giving, too, next year, a much higher grade of seed. It will pay even the one-horse farmer tot buy one of these $\$ 50.00 \mathrm{ma}$ chines. Hand Power. Good for big and little seed. We chines. Hand Power. Good for big and little seed. We Cotton Seed Grader on the market. We are local agents Cotton Seed Grader on the market. We are loce
and make large sales of them. Price $\$ 50.00$.

\section{Medium Size Bolls, Short Staple.}

WIITET'S SPECIAT “EXPRESS COTTON',- (Lint, 1 1.8 to 1 3-16.) New A most valuable Anti-Boll Weevil cotton. Bred by government. The two Miss. Exp. Stations report first pickings of Express 400 pounds more than any other cotton, and that it is the best cotton in Miss. Delta and boll weevil lands. Ira W. Williams, governmen expert in cotton breeding, writes that Express. Cotton is earlier than Kings or Simpkins. Felix Williams, employed by Ga. Com. of Agl., writes that Express yields as much seed as the very best. The lint is $11-8$ to $13-16$ (and in Miss. $11 / 4$ ), which gives it $3 \mathrm{c}$ to $4 \mathrm{c}$ a pound premium. Bolls are fairly large. Gives us extra earliness, productivity and lint length, and with some anthracnose resistant qualities, Express is a triumph in cotton breeding. A state college experiment made at Waynesboro, Ga., 1915, showed Express to be the earliest of 9 cottons as tried out; and from one acre first pickings made on September $7 \mathrm{th}$, and made in 4-foot rows, a 400 -pound bale of lint was made. First pickings, 1917, 'Waynesboro test, 1,404 lbs. Total two pickings, 1,914 lbs. G. P. K., Ga., says: "The best of all boll weevil cotton. Earlier than King's; in boll weevil lands it is the 'obligatory' cotton to grow. 'While it turns out less at the gin-about 31 per cent-yet I get an turns out less at the gin-about 31 per cent-yet I get an extra early crop, and get a premium for my lint.' Express sold Augusta Oct. 15, 1917, 5c premium. Near Augusta, M. P. $P_{2}$ who planted 191720 acres, got $11 / 2$ bales per acre,
first picking $1,200 \mathrm{lbs}$. cotton in seed, and $800 \mathrm{lbs}$ second picking per acre. The demand, 1919, will be immense Other " 90 -day" cottons make their crop all at once an then stop, while Express keeps on making. The plant is of good size and well-rounded and shapely and magnificently fruited. The finest cotton field in Augusta suburbs in 1918 was a 50-acre field of Express. Seed fairly large and some of them green. Tenn. Exp. Sta. says earliest and most prolific cotton known. Miss. Exp. Sta says our ear. liest and most prolific cotton. One party, i918, near Augusta, made 68 bales Express on 58 acres. Price: On bushel $\$ 3.00 ; 5$ bushels $\$ 2.75 ; 25$ to 50 bushels $\$ 2.60 ; 100$ bushels $\$ 2.50$.

WILIET'S SPECIAL TOOLE-(Short Staple.)-Early; for boll weevil lands. Of King's type; low bush; shapely. Hybrid of King's and Peterkin; originated at Augusta, A few days later than King's; but is taller, more prolific, more limby, lint longer, bigger bolled than King's. In Georgla $81 \%$ is picked by September 7 th. Can plant two stalks to hill, 18 inches in row. Gins 40 to $42 \%$. Bolls weigh 87 to pound. Height 3.63 feet. Small seed. Recommended and distributed in boll weevil sections by the United States government. So prolific is it that it is the best-known cotton today in the South! For ten years tremendous slipments have gone into the Southwest. We have a fine list of experienced So. Car oro have a fine list of experienced So. Car. growers. Three-fourths of Augusta territory use Toole. One Louisiana grower made 1,001
bales on 1,000 acres. Willet's Toole, in many cases, made bales on 1,000 acres. Willet's Toole, in many cases, made mological Dept.. Waynesboro, Ga., as made 1917, gave Toole first picking September $7 \mathrm{th}$ on one acre was $1.080 \mathrm{lbs}$. second picking $795 \mathrm{lbs}$; and the total two pickings 1,875 lbs., with a fair picking not enumerated for the third picking. Comparatively out of nine cottons as tested, Toole stood second in the summary of the first and second pickings The Toole we have is almost absolutely inime to anthracnose and boll rot. The goveriment expert at Fort Gibson, Miss., leading authority on early anti-boll weevil cottons, says that the best two cottons are King's and Toole, King's being slightly earlier, but Toole being more prolific. Pre-eminently the prolific small boll cotton for the South. Planted June 10th, Augusta, made 20 bales on 12 acres; one man made 22 bales to the plow. Here at

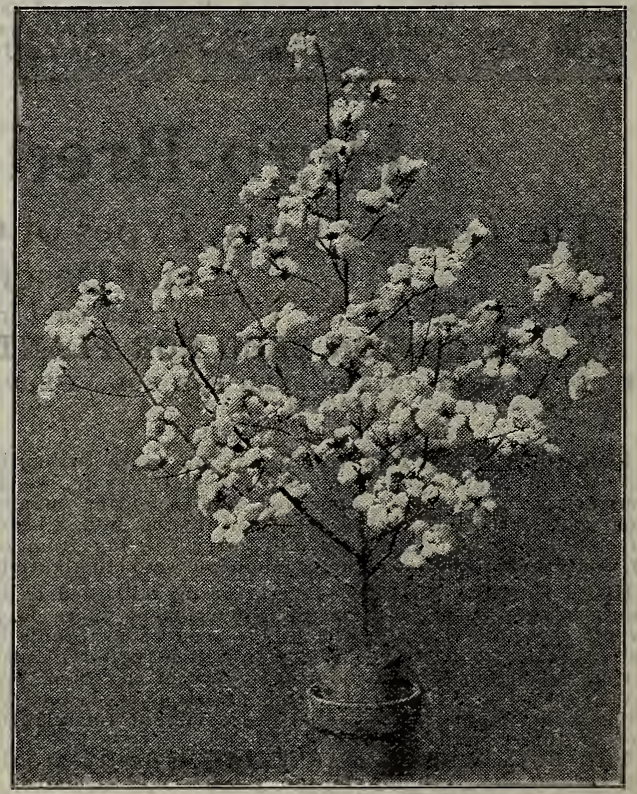

Toole Cotton.

Augusta, 107 bales of Toole have been made on 100 acres At test Alabama Experimental Station of 32 varieties, Toole stood first; also at Ga. Experimental Station. At South Carolina Experimental Station, three gin tests showed 40 to 42 per cent at gin. Large amounts sold in Texas for 
planting after Irish potatoes. Texas reports it does not shed with them as badly as others. 1,250 pounds gins ou. a bale 505 to 510 pounds. Alabama Experimental Station
reports 81 per cent picked from fields by September 7 thonly a few days later than King's. Magnificently productive. Comes early and holds on fruiting until late. Fine results on poor land. Stands drought and negro usage. Very stocky, limb close with short boll joints, often medium size, seeds small. Matures a heavy crop early, reacts quickly and hurries for a full top crop. Stalk, beautifully quickly and hurries for a full top crop. Stalk, beautifully We have a photograph showing 32 open bolls on one limb

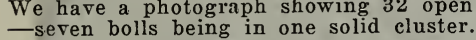

We have furnished a large number of carloads of Toole cotton seed through the various United States Agricultural demonstrators in the Southwest, because, as they say, Toole is not only early, but it is exceedingly prolific; and is especially valuable on the rich bottom lands of the Southis especially valuable on the rich bottom lands of the Southwest because the stalk of Toole does not grow too large. bushels at $\$ 2.25 ; 100$ bushels at $\$ 2.15$. Get prices delivered in car lots.

WILLET'S SPECIAL KINGS-(Short Staple, 7-8-in.) -Syn., "Sugar Loaf") -Small stalk, spreading limbs, pyramid shape. Planted at Augusta June 20th, past season made bale per acre. There are all kinds of King's cotton seed sold up in North Carolina and the poor kinds are not worth 25 per cent of the good kind.

The government expert at Port Gibson, Miss., leading authority today in the world on early anti-boll weevil cotton, says that the best two cottons are King's and Toole, King's being slightly earlier, but Toole being more prolific The earliest cotton in the United States. 103 bolls make 1 pound cotton seed. About $381 / 4$ pounds lint to 100 pounds seed cotton. Carolina growers report 82 per cent open by September 1st. Average about 3 feet high. King's opens September 1st. Average about 3 feet high. King's opens
in Texas, July 15th; in Georgia several weeks later. Proin Texas, July 15th; in Georgia several weeks later. Pro$30 \mathrm{th}$, and it had blooms in six weeks.

An Augusta party for many years from middle June plantings has gathered over a bale to the acre on a certain 20 acres of land without fertilization except that received from winter vetches sown in fall and cut May 1st. Boll is medium; seed very small and green-like. Sometimes makes fine top crop. Invaluable for planting after wheat, oats, beardless barley, and Irish potatoes. Wherever a short growing season is necessary, King's is above all others. The salvation of all boll weevil lands. King' makes its crop before boll weevils have become through

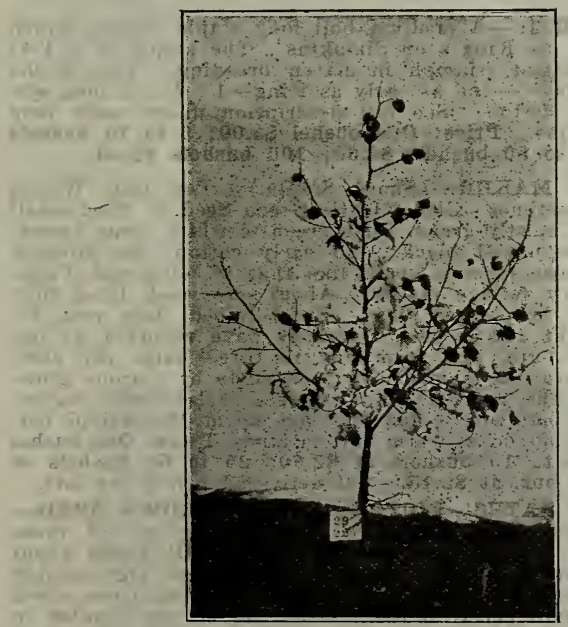

Willet's Special King Cotton.

their cycles numerous. Boll weevil states should come here every year for these and other seed in preference to weevil infested seed. The old name of this cotton was "Sugar Loaf," named on account of its pyramid shape, and with about 20 per cent of blooms showing red spots on them This is the King's as is annually sold today. Our North Carolina growers, whose crops we control, which we call Willet's Special King's, have bred this cotton so as to now show of ten 75 to 80 per cent blooms with red spots Largewith red spots Large ly immune to anthracnose, only 1 per cent. We offer this North Carolina King's stock, f. o. b. Augusta. Price: One at $\$ 2.35 ; 100$ bushels at $\$ 2.25$. Get delivered prices on car lots.
WILLET'S “PERFECTION” EARLY COTTON-(Short Staple.) New, only listed by us, Bred by one of the most scientific growers in Augusta territory. Was bred from

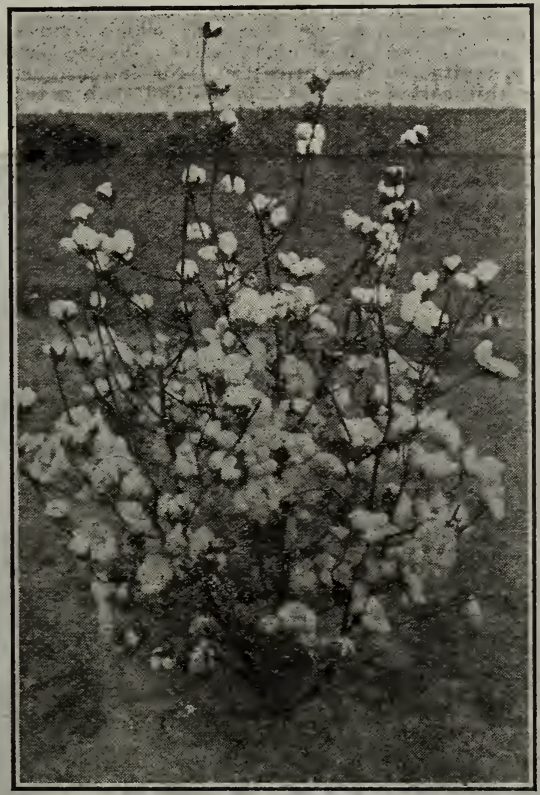

Perfection Cotton.

Toole; and for six years the breeder has been selecting his seed for earliness, productiveness and a larger size boll. We can say this is one of the most prolific early medium boll cottons we have ever seen. Each year there is, in early anti-boll weevil cottons, a betterment and an evolution. prettiest, most uniform and homogeneous known. Its points of superiority are: It is practically as early as King's, one of the most prolific, larger boll than Toole, less costly to pick than Toole, better lint and smaller seed-all strong, advantageous points. We predict for it a wide circulation. Our grower is the originator. There is only a limited Our grower is the originator. There is only a limited small amount. Our grower-last year got 1e a pound premium for Perfection lint, and actually made a 500-pound bale from 1,100 pounds cotton-in-the-seed. Bushel at $\$ 3.00$ 5 to 10 bushels at $\$ 2.75 ; 25$ to 50 bushels at $\$ 2.60 ; 100$ bushels at $\$ 2.40$.

WILLET'S SPECIAL SIMPIINS EARIY PROLIFIC(Short Staple.) Early for boll weevil lands. A selection from King's cotton. Resembles King's very much in growth and shape. Equally as early. Certain exploiters have advertised this cotton as being ten days earlier than King's and have made big money on it. This is wholly untrue, and is unjust to buyers. King's and Simpkins open at same time.

A grower says: "The superiority of this cotton consists in its extreme earliness and heavy fruiting. Has long limbs which come out at the ground; has close joints and small seed, and yields well at the gin. One grower in Louisiana who planted 1,200 acres in it in a completely in fested boll weevil district is reported to have made 509 pounds lint per acre with Simpkins, and made only 200 pounds with some later cotton.

The N. Car. Exp. Sta. writes us that Simpkins and King's cottons are of the same general type; Simpkins cotton is a strain of King's. The Exp. Sta. tests indicate that King's seed and good Simpkins seed are about of equal merit. We offer fancy North Carolina stock, f. o. b. Augusta. Price: One bushel $\$ 2.85 ; 5$ to 10 bushels at $\$ 2.60 ; 25$ to 50 bushels at $\$ 2.35 ; 100$ bushels at $\$ 2.25$. Get delivered prices on car lots.

WILLET'S SPECIAL HITE'S PROLIFIC-(Short Staple.) An Augusta origination. A most prolific cotton, also early, probably week later than King's. Easy to pick; good lint and staple. Weed inclined to be somewhat of dwarf nature, an open growth with distinctive forked leaf, thus admitting the sunshine. Long tap root, resists drought. Three to four branch limbs at or near ground branching out other limbs all the way to the top. They are all laden out; other limbs all the way to the top. They are all laden
down with bolls. If proper space is given usually spreads out as wide as it grows high. Medium size boll, 80 to 85 to the pound of seed cotton. Gins from 40 to 41 per cent of lint. While not entirely double-jainted cotton, you will 
find several limbs on each single plant with two bolls growing opposite each other as many as 10 to 16 bolls in 10 to ing opposite each other, as many as 10 to 16 bolis in fertilization, Hite's Prolific Cotton should produce $1 \frac{1 / 2}{2}$ bales per acre. Well suited to all soils. Clemson College pronounces this cotton absolutely free from anthracnose, which is a great consideration. See cut, which represents an average stalk from a field of 17 acres. Notice particularly that it is fruited to the entire top. No better recommendation for this cotton can possibly be had than a test at the Ala. Exp. Sta. at Auburn. Out of 29 varieties and strains

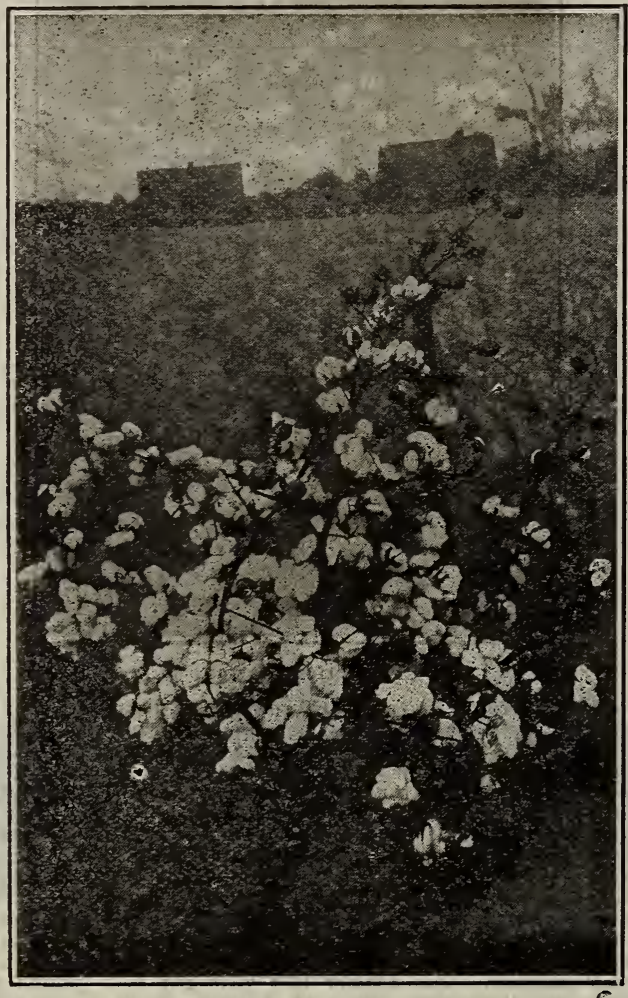

Hite's Prolific Cotton.

of cotton, Hite's led them all. It was the most productive variety, making net $\$ 5.22$ per acre more than the next most prolific, and $\$ 33.14$ more than the least productiv variety. In these tests cotton was planted on April 25 th on sandy upland soil and fertilized at the rate of 400 pounds per acre, consisting of Acid Phosphate, Nitrate of Potash and Nitrate of Soda. Out of a So. Car. test of 27 varieties, Hite's cotton was more immune to the red spider than other varieties-being open growth and admitting the than other varieties-being open growth and admitting the report in numerous cases more than 350 bolls per stalk of cotton and report out-turn to be so large that picking is the one and only consideration. Price: One bushel $\$ 2.75$ 5 to 10 bushels at $\$ 2.50 ; 25$ to 50 bushels at $\$ 2.25 ; 100$ bushels at $\$ 2.15$. Get delivered prices on car lots.

WILLET'S SPECIAL BROADWELL'S DOUBLEJOINTED-(Short Staple.) Very early; for boll weevi lands. Originated in Georgia. United States Agricultural Department says: "A strain of King; seeds very small, green or brown gray; flowers often have red spots; 100 bolls to the pound ; lint 13-16-inch" " Bolls medium; limbs under and close to the ground. The originator has i limbs tificate from his gin company showing that he gathered in 1905,12 bales of 400 pounds each from four acres. Very early; has the King cotton red spot in bloom and is close kin to King. The originator writes: "I have averaged three bales to the acre on my entire crop. I have made two bolls where one has been growing before; the limbs grow in pairs from the main stalk, and two bolls grow side by side on limb." There is not so large a percentage of red spot in the white bloom as obtained in King's cotton. It often has a more vigorous stalk, and is not so dwarf as is King's. This cotton close kin to and is practically what King's or Simpkins is. Price: One bushel $\$ 2.85 ; 5$ to 10 bushels at $\$ 2.60 ; 25$ to 50 bushels at $\$ 2.35 ; 100$ bushels at $\$ 2.25$. Get delivered prices on larger amounts.

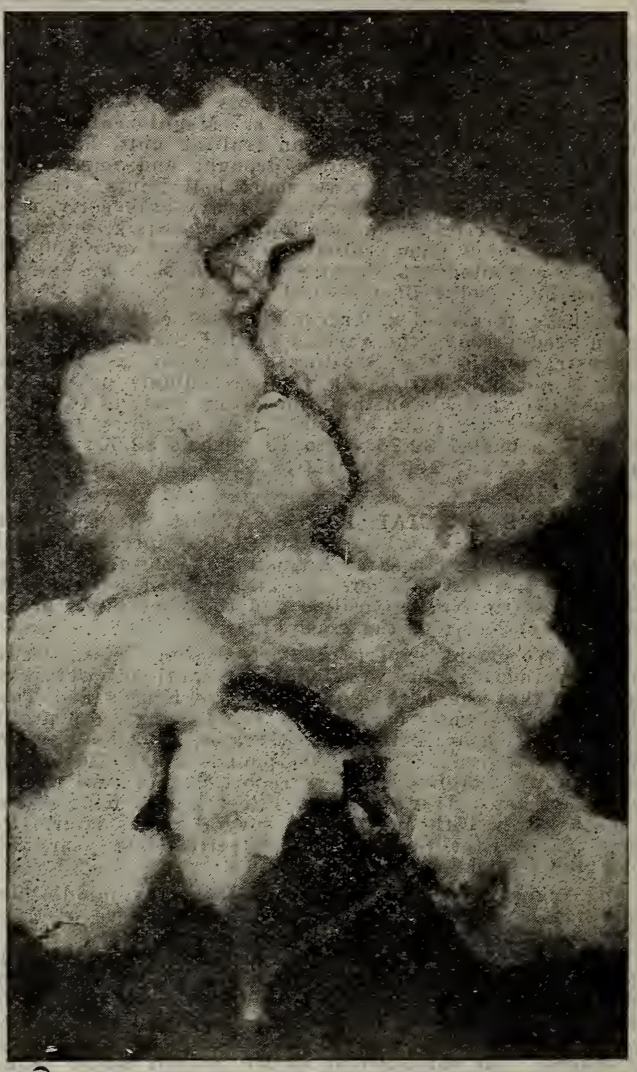

Broadwell Double-Jointed Cotton.

WEBBER 49-A medium boll long staple cotton, which is as early as King's or Simpkins. The staple is 11.4 ; it is our latest triumph in cotton breeding. This is the only "90-day" -and as early as King-1 1-4-inch long staple upland cotton. See full description under early long staple cottons. Price: One bushel $\$ 3.00 ; 5$ to 10 bushel $\$ 2.75 ; 25$ to 50 bushels $\$ 2.60 ; 100$ bushels $\$ 2.50$.

MONEY MAKER-(Short Staple.) For Boll Weevil lands. Sometimes called "Little Green Seed." "Sèd small to medium, mostly green, some green to white, some brown, with a few naked black. An early cotton, the growing type of whose form is small like that of King and Toole. Not a heavy foliage maker. About one week later than King. Can be planted close. Short-limbed, deep root, resists. drought and storms. Growers have reported 43 per sists drought and storms. Growers have reported 43 per cent at the gin, and from one to three bales per acre. $\mathrm{ers}$ as to the outcome in the field. Especially recommended in boll weevil districts and warm Mississippi bottoms and other moist warm bottom lands. Price: One bushe at $2.75 ; 5$ to 10 bushels at $\$ 2.50 ; 25$ to 50 bushels at $\$ 2.25 ; 100$ bus. at $\$ 2.15$. Get delivered prices car lots.

BATES; BATES' VICTOR; BATES' BROWN SEED(Short Staple.). This cotton is known by all of these names. It originated in South Carolina. It yields about 42 per cent of lint at the gin. These seed are possibly our smallest cotton seed. Exceedingly homogeneous; look all alike, with rarely a black seed. It is very similar in out-turn to Toole cotton. Some people erroneously call it "50 to 50." It is of the Peterkin type. One stalk at the Augusta Exposition in 1891 in the writer's possession, showed 681 opened, well-developed bolls on it. It takes over 100 bolls to make one pound of seed cotton. Seeds are brown. Possibly not quite so limby as Toole. Stalks fruit well. Medium early cotton. One bushel $\$ 2.75 ; 5$ to 10 bushels at $\$ 2.50 ; 25$ to 50 bushels at $\$ 2.25 ; 100$ bushels at $\$ 2.15$.

SAWYER COTTON-This cotton came out of a Toole field The boll, however is later than Tot of a Toole early or a trifle earlier than Cleveland. Carries a smaller stalk than Cleveland and a trifle larger percentage of outturn at the gin. It has only a small amount of foliage. Price: One bushel $\$ 2.85 ; 5$ to 10 Dushels $\$ 2.60 ; 25$ to 50 bushels $\$ 2.35 ; 100$ bushels $\$ 2.25$. 


\section{The Earliest Big Boll Varieties.}

\section{LENGTH OF LINT 1 TO 1.16 INCH.}

MEBANE'S EARLY TRIUMPH-BIG BOLI-(Short Staple.) Early for boll weevil lands. Largely storm proof. Largely immune to anthracnose. Originated in Texas. More largely used in Texas than any other big boll cotton-and Texas uses principally the big boll cottons-because they

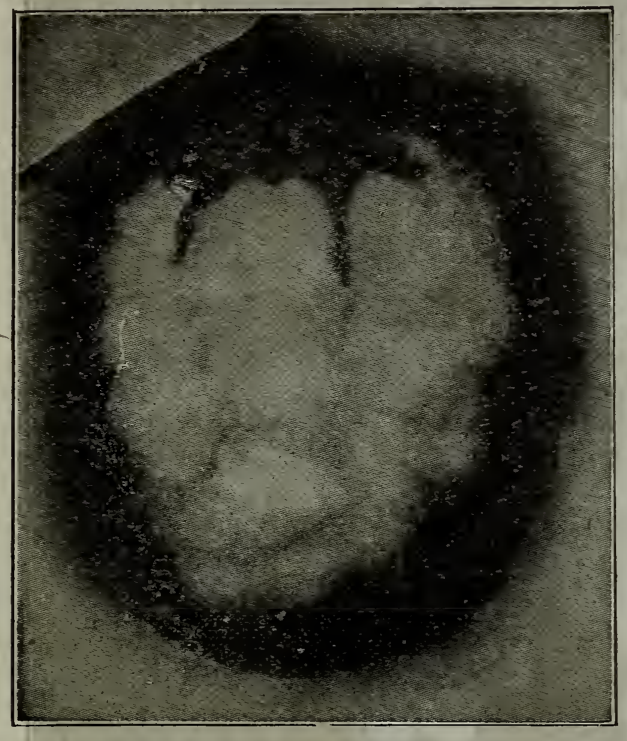

Mebane Triumph Cotton.

are more easily picked. Immense boll, 46 to 50 bolis mak ing one pound of seed cotton. Earlier than most big boll cottons. Seed fuzzy, medium in size, brownish and greenish white, with some green seeds showing its hybrid character. This variety has been especially satisfactory in reacter. This variety has been especially satisfactory in re gions infested with the boll weev
large amounts and at high prices.

The originator says: "This cotton has a strong, thrifty, deep-rooted stalk that resists drought well. Has long limbs with short points. Begins to form bolls near the ground with short points. Begins to form bolls near the ground and close to stalk. Bolls are large, mostly five-lock. Produces large, well-dereloped bolls at top of stalk and end
of limb to the end of the season. Fifty of the largest bolls make a pound. The cotton stays in well after opening. It is one of the earliest big boll cottons. 1,300 to 1,500 pounds seed cotton made 500 to 600 -pound bales. Price: One bushel $\$ 2.85 ; 5$ to 10 bushels at $\$ 2.60 ; 25$ to 50 bush els at $\$ 2.35 ; 100$ bushels at $\$ 2.25$. Get special delivered prices on car lots. See cut.

HALF AND HALF, or "FIFTY-FIFTY" -A largely advertised cotton; was bred out of the old-time Cooks cot-

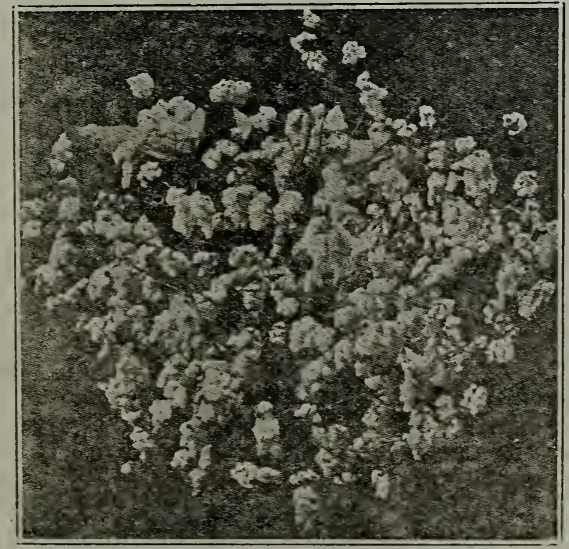

Half and Half Cotton. ton. Exceedingly prolific; high percentage at the gin. Great favorite with a large number of cotton growers. Boll is medium; early, iint about 7-8-inch.

This cotton is about as early as Cleveland and is really one of our most prolific cottons. Its very high percentage at the gin has given it its name of Half-and-Half. We have good stock. Price:-. One bushel $\$ 2.75 ; 5$ to 10 bushels $\$ 2.50 ; 25$ to 50 bushels $2.25 ; 100$ bushels $\$ 2.15$.

ROWDEN EARLY BIG BOLI-(Short Staple.) Early for boll weevil lands; lint 1 to 1 1-16 in. It originated in Texas. Big boll, 50 bolls making one pound seed cotton. Bolls are pointed. Quite storm-resistant. Locks mostly five; hang together, and picking with it is quite easy. Lint percentage is above medium; maturity medium. It is one of the prime favorite varieties in the boll weevil region of Texas. Price: One bushel $\$ 2.85 ; 5$ to 10 bushels Get special delivered prices on car lots.

POULNOT BIG BOLI-In Northeast Georgia this is one of the principal cottons as grown, and it has there an immense sale. The boll is the size of Cleveland, and it is as early as Cleveland. It carries an extra strong staple of 1 to $11-16$ inch. Adapted to boll weevil lands. It is exceedingly prolific. The largest planter in this county who grew nothing else this rear, averaged $11 / 2$ bales to Who grew nothing else this year, averaged $11 / 2$ bales to
the acre. The plant has rather a large stalk. A field of the acre. The plant has rather a large stalk. A field of 5 to 10 bushels $\$ 2.60 ; 25$ to 50 bushels $\$ 2.35 ; 100$ bushels $\$ 2.25$.

WILLET'S IDEAL BIG BOLI-(Extra early short staple.) The originator has been crossing and selecting for earliness the Ideal Big Boll varieties for a number of years. It is a hybrid of Clereland and Poulnot, crossed with the earliest varieties. After his cross was made, this cotton was selected for earliness and prolificness for seven years before being placed on the market. This hybrid is of the Cleveland type and quality. There is only a limited amount Cleveland type and quality. There is only a limited amount
of seed to be had. It has little foliage. It grows straight up. It has the same big boll as Cleveland, and the same lint-1 1-16 inches. This is more of a cluster cotton than the Cleveland, and can be planted closer together. See big cut on front outside cover.. Price: One bushel $\$ 3.25 ; 5$ to 10 bushels at $\$ 3.00 ; 25$ to 50 bushels at $\$ 2.75 ; 100$ bushels at $\$ 2.50$. Get special prices on larger amounts.

WILIET'S SPECIAL CLEVELAND BIG BOLI-(Short Staple, Early; for boll weevil lands. It has large bolls and good fiber, which measures from It has large bolls inches. No other cotton has from 1 inch to 1 .16 records, standing practically first, with them. Three-fourths out in field September 20 th, and all out October 5th. Ear liest among the big bolls. A picker can gather 100 pounds of Cleveland cotton while he gathers 71 of small bolls. Pickers are refusing to pick small boll cottons. More Clereland was therefore sown in 1918 than any other cotton, and the amount will be still increased in 1919thus making it the most popular of all cottons. Seed are light, though large. Kernels fit loosely.

The United States Agricultural Department says: "Quite early in maturity, 50 per cent five-locked, seeds largely fuzzy, light brown gray ; origin, Mississippi."

Large boll, 55 per pound. Cleveland carries less foliage than other big boll cottons. It is largely desired above them all, in the Mississippi and Louisiana bottoms. It is practically free from anthracnose, suffering less than most big bolls

The stalk is branching in growth with five or six primary limbs; the first limbs are long and begin near the ground, an essential feature in early cotton; 1,300 pounds per acre had been gathered from it this year by September 11 th, on strong bottom land. One of the best varieties for all parts of the South, whether the boll weevil be present or not.

An Experiment Station says: "Plants large and low spreading, rapid grower, heavy foliage, bolls are nearly round, mostly have five locks; 50 bolls to the pound; lint of the best quality, 1 to 1 1-16-inch. Largely free from disease. 1,210 pounds make 500-pound bale. Seed are medium size with a few black seed. One of our choicest big boll cottons." One Augusta cotton factor who sold 200 bales of Cleveland cotton found that 60 per cent of it ran to 1 1-16-inch lint length. The growers of Cleveland should insist that they be given a premium for the extra length over 1 inch. South Carolina mills pay a premium for Cleveover 1 inch. South carolina mils palf picked out. The two well known types of Cleveland are Reddings and Wannamaker. Order of us, either type that you may wish. While a cotton stalk will show more bolls of a medium size, and thus a field of it will appear more prolific than where the bolls run 55 to the pound, yet the field of big bolls will be easier to pick and the field may show in the end a larger field out-turn. Georgia Entomological Department, at Waynesboro, Ga., in experiment, picked out 1,120 pounds of Cleveland from one acre first pickings made September 
7 th; total from two pickings 1,740 pounds. See cut. 50 bushels at $\$ 2.35 ; 100$ bushels at $\$ 2.25$. Get special delivered prices on car lots.
DIX-AFIFI-Early; long staple. Wilt proof. Bred by Ga. Ent. Dept., being a cross of Dixie. Wilt Cotton and Egyptian Cotton. Has a lint of 1 1-4 inch, carrying a premium of $10 \mathrm{c}$ per pound. At Waynesboro, Ga., a test

\section{LONG SHANK, or SHANK-} HIGH-A favorite in North Georgia; and used in South Georgia; and used in South Tall stalks, big boll, short limbs, very few limbs and very few leaves and foliage. Productive. Makes rapidly. In the fall the stalk seems to turn to cotton which all opens and which never seems to catch the frost. Plant only in three foot rows, 10 inches in the row. Same earliness and easy picking as in Cleveland. Carries a long shank, for it does not limb until it gets to be 12 to 15 inches bigh and, therefore, can be plowed within five days after coming up. Resembles somewhat in growth the Old Jackson Limbless. Price: 1 bushel $\$ 3.00 ; 5$ to 10 bushels $\$ 2.75$. $\$ 3.00$; 50 to 10 bu bushels $\$ 2.40$. See Cut following page.

MEXICAN BIG BOLL-In large use in South Carolina and in Oklahoma. About as early as Cleveland, but carries a trifle better staple and frequently sold as 1 1-8 lint. Seed are white and very large. Large stalks, but limbs cluster and grow close together. Price: One bushel $\$ 2.85 ; 5$ to 10 bushels $\$ 260 ;$ $\$ 2.35 ; 100$ bushels $\$ 2.25$.

\section{Varieties We Recom- mend for Wilt-Infested Land.}

NOTE-In fields infested by Wilt, plant no cotton except other cottons means a loss of 60 to 80 per cent of the crop. Wilt is a soil fungus that through the root ducts gets up

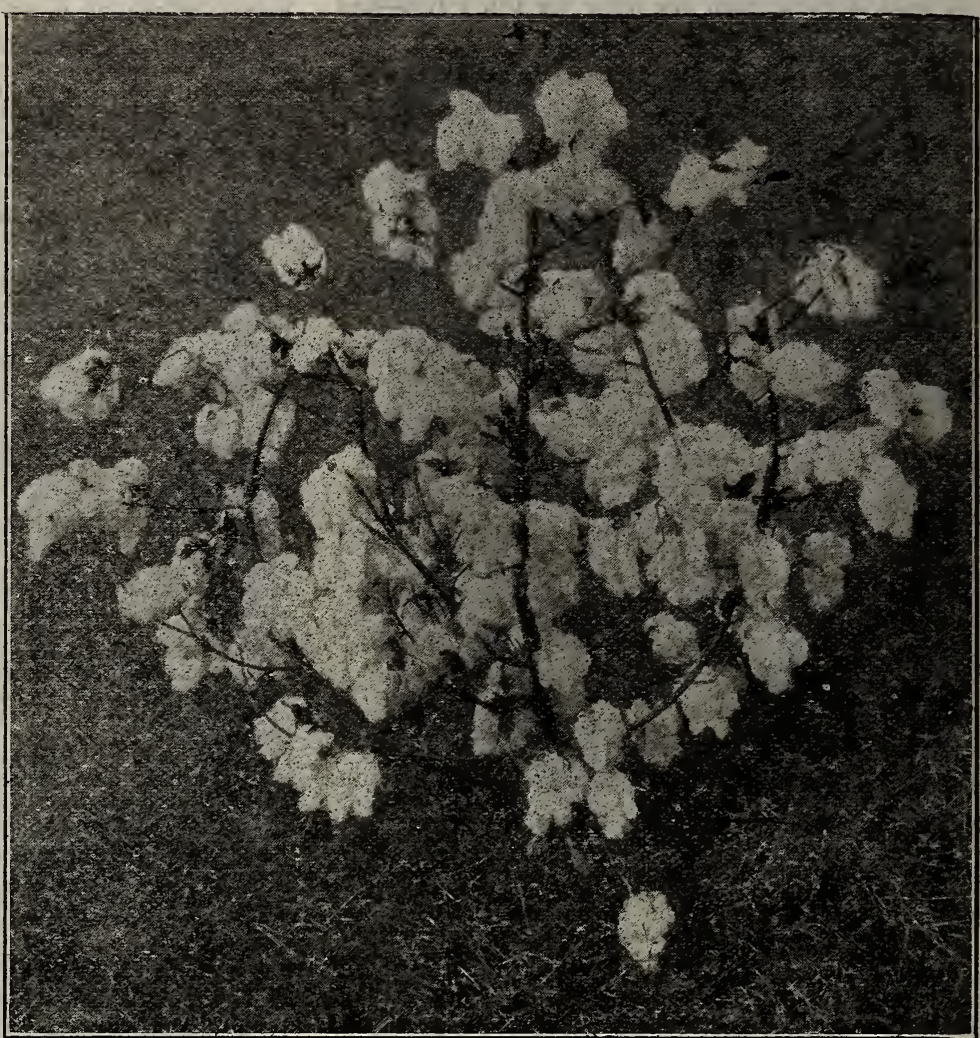
into the plant's sap ducts, and

growing, fills these ducts and prevents plant from getting water; the plant slowly wilts and dies. No other remedy here except a wilt-resistant cotton. Wilt lands are increasing by 10 per cent each year in the coun try and causing a loss often of 50 per cent of crop. Black root, or Root Knot, is a different disease, and caused by microscopical eel worms in the soil that attack cotton and a large number of other plants. The only remedy here is to plant land two years in velvet beans or Iron or Brab. ham cow peas in summer and follow with grains in the fall.

COUNCIL TOOLE-Anti-Wilt. In order to improve the old style Covington-Toole as an anti-wilt, our Ga. Ent. Dept. has for the past three or four years been making selections and has been breeding a cotton that is the more wilt-resistant and also more prolific. Council Toole has been put on the market by them as being the best Toole type wilt-resistant cotton. This cotton is like Toole in every respect except that it has been bred into absolute wilt-resistance. Our grower grows about 6,000 bushels and gets the finest results and has been growing it under the supervision of the Ent. Dept. of this state. Our grower with Council Toole made one bale to the acre on over 200 acres and on wilt land that had showed in loss nearly 50 per cent the ycar before. Price: Cne bushel $\$ 3.00 ; 5$ to 10 bushels at $\$ 2.75 ; 25$ to 50 bushels at $\$ 2.50 ; 100$ bushels at $\$ 2.40$.

WILLET'S IMPROVED DIXIE WILT-RESISTANT(Short Staple.) Credit of originating is due Mr. W. A. Orton, of the Department of Agriculture, Washington. Late, not adapted to boll weevil land. This is a medium size plant, and is now very prolific. Bolls small to medium, about 85 to make a pound of seed cotton. Staple length 7-8 to 15-16 and strong; per cent of lint, 38 to $40 \ldots$ One bushel $\$ 3.00 ; 5$ to 10 bushels at $\$ 2.75 ; 25$ to 50 bushels at $\$ 2.50 ; 100$ bushels at $\$ 2.40$. Get delivered prices on car lots.

Cleveland Cotton.

was made by the Ga. Ent Dept, 1916, and Dix-Afif gave September first picking 1,110 pounds; second picking, October 10 th, 570 pounds; total two pickings, 1,680 pounds per acre. This same test, 1917, at Waynesboro, gave 1,394 pounds sced cotton first picking. In a letter to a man in the weevil territory, Mr. E. L. Worsham, State Entomologist, wrote: "Probably there is no better cotton for you in your section than Dix-Afif. It is very resistant to wilt and root knot, and fruits as early as King." This statement of Mr. Worsham that the c:tton is early, and as early as King, and the result of September 10th first picking at Waynesboro being $1,110 \mathrm{p}$ )unds, shows a remarkable earliness for this cotton. This cotton, therefore, carries earliness, wilt-resistance, and premium in the matter of lint. N. C. H. says: "I lost 50 per cent of cotton crop through wilt. With Dix-Afifi I do not find three dead stalks on plantation." It is one week later than Express. Seed are small-s me white, some black (Egyptian). It is absolutely resistant to wilt and carries a certain superiority over all other anti-wilt cottons. For the grower who wants an early anti-wilt boll weevil cotton and aiso a long staple premium lint cotton, there is no other cott $\mathrm{n}$ for him to buy except Dix-Afifi. It is just as productive, too, as the short staple cottons. It is one of the most remarkable cottons that has becn developed in recent years. Seed in great demand and scarce. Price: Cne bus el $\$ 3.10 ; 5$ to 10 bushels $\$ 2.85 ; 25$ to 50 bushels $\$ 2.60 ; 100$ busisels $\$ 2.50$. See Cut on following page.

COVINGTON-TOOLE WILT-RESISTANT-Toole cotton, which is the principal cotton grown in the Augusta territory, and seems so well adapted to sandy lands, has been bred into a wilt-resistant cotton. Owing to the fact that very many people are wedded to Toole on account of its earliness and its productivity this Wilt-Resistant Toole is a most valuable addition to the cotton world. One lot of 125 acres near Augusta that had been abandoned for 
cotton planting on account of wilt, this past eason, as planted to Wilt-Resistant Toole, produced as fine cotton as there was in South Carolina. $\mathrm{T} \mathrm{h} \mathrm{e}$ earliest of all anti. wilt cotanti - wilt cottons. An excellent wilt-resistant cotton for lands. Price: 1 bushel $\$ 3.00 ; 5$ to 10 bushels at $\$ 2.75 ; 25$ to 50 bus, at $\$ 250$. 100 bushels at $\$ 2.40$. Get delivered prices on car lots. IEWIS' 63 WILT RESISTANT-(See cut) A cross between Dixie and Dillon wilt-resistants. Bolls me dium. Earlie $t h$ a $n$ Dixie. Short staplelint $7.8-38$ per cent at gin absolutely wiltabsolutely wiltby Mr. A. C. by Mr. A. C. Ent. Dept. Has a high record for productivity. In Bulletin No. 40, Ga. Board Ent, at Vienna, Ga., out of 16 cottons s t o o d cottons s t o o d
first, 1,829 lbs. first, 1,829 lbs. seed cotton per kin, Ga, out of 21 cottons it stood third; at Hawkinsville, Ga., out of 10 cottons it

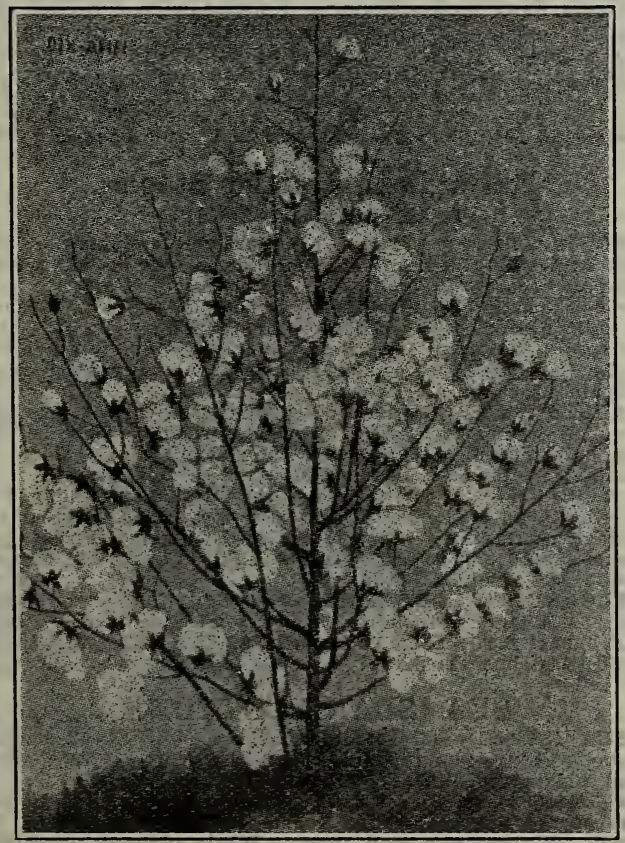

Stalk of Dix-Afifi Cotton. stood first. All these tests made on wilt lands, First pickings, Waynesboro, 1917 test, 1,394 pounds: total pickings 2,038 pounds. Our grower made one bale to the on 250 acres Lewis' 63 on wilt land where cotton had on 250 acres Lewis 63 on wilt land where cotton had
died 25 to 50 " per cent the year previous. For a short

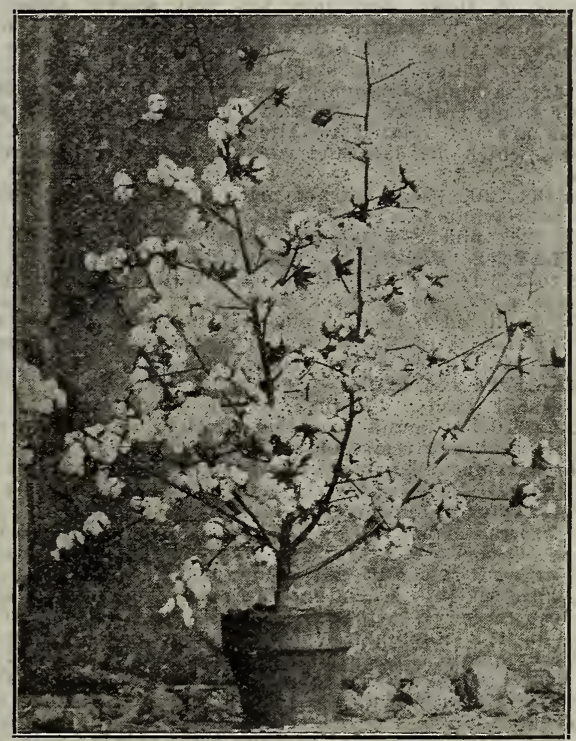

Stalk of Council-Toole Cotton.

staple, productive and fairly early, absolutely wilt-resist ant cotton, Lewis' 63 probably stands at the head. Price: One bushel $\$ 3.00 ; 5$ to 10 bushels at $\$ 2.75 ; 25$ to 50 bushels at $\$ 2.50 ; 100$ bushels at $\$ 2.40$.

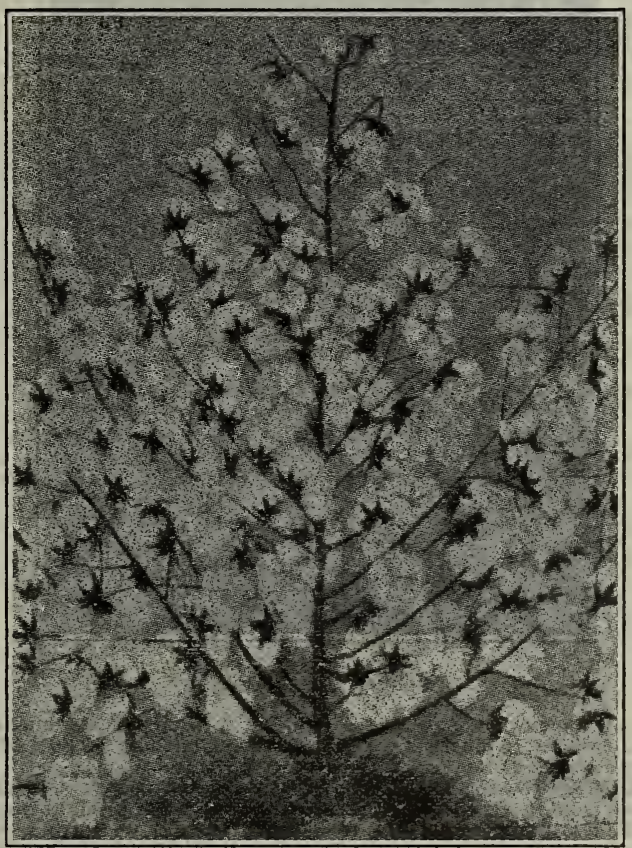

Lewis' 63 Wilt-Resistant.

Extra Early Long Staples-Big Boll (1 3-16 to 11-4-inch Staple).

NOTE-The only Long Staples possible in boll weevil territory are the Early Big Boll, 1 1-4-inch; strong, rough staples, the near equivalent of Egyptian cotton, and evolved 
some years ago by U, S. Gov, by crossing Egyptian and Am. big bolls. Fetch today about 10 cents premium. An good demand. Large amounts are grown in CarolinaIn good demand. Large amounts are grown in Carolinaamounts of these seed into the boll weevil areas. As grown in South Atlantic States, they are equal to Mississippi Delta types and are earlier and more prolific and have larger bills. Long staple cottons are in good demand and carry a high premium. There is an increasing demand for all staple cottuns. The early new big boll early staple cottons are not related to Allens, Floradora, etc., $1 \frac{1 / 2}{\text {-in }}$ cottons, which are late and can't be raised in boll weevil lands.

On Oct. 20,1918, market price of staples were as fol lows in Savannah: $13-16 \quad 36 \mathrm{c} ; 1 \quad 1-4 \quad 37 \mathrm{c} ; 1 \quad 3-8$ 39c $1-242 \mathrm{c}$; and Sea Island $68 \mathrm{c}$.

WILLET'S SPECIAL "EXPRESS COTTON"-(Lint 1 1-8 to $13-16$.) New. Bred by government. This $c$, thon is listed a few pages back under very early cottons. It should be listed here also amongst the extra long staples, as it carries extra staple and brings a premium. See decription and price a few pages back.

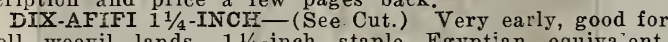
boll weevil lands, $1 \frac{1 / 4}{4}$-inch staple Egyptian equiva:ent, bringing $10 \mathrm{c}$ a pound premium, prolific and fairly early, and our best wilt-resistant cotton. See a few pages back for description and prices under "Wilt-Resistant Cottons."

WEBBtR 49-Originator says: "Earliest of all long staple cottons. Length 1 1-4 to $15-16$. Practically as early as any short staple. Good yielder. Universal report is Webber 49 is the best staple cottcn ever produced and improved this strain, until now it has proved by actual test to be the superior of any staple cotton yet produced in the combination of earliness and character of staple." Small stalk, identical in looks with King's. Cut shows average stalk, three feet high; pyramid shape exceedingly shy of foliage-practically none. Very early, earlier than Toole's or Cleveland. 75 per cent of it this year was open in August; medium boll; thirds itself at the gin. It bolls along the stem clean up to the top. Opens of the brecding of this cotton was to get a long staple

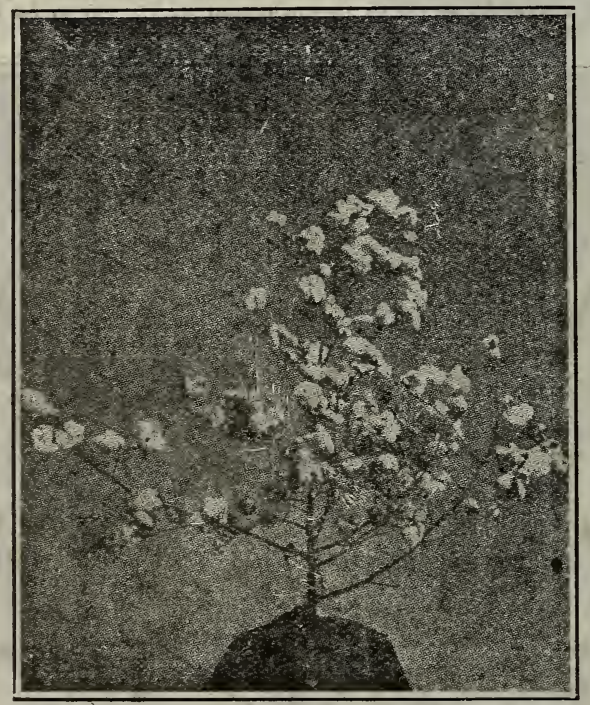

Webber 49 Cotton.

cotton that was as early as King's." Price: One bushel $\$ 3.10 ; 5$ to 10 bushels $\$ 2.85 ; 25$ to 50 bushels $\$ 2.60 ; 100$ bushels $\$ 2.50$.

DURANGO 11/4-INCH-U. S. Government says: “Durango is a newly acclimated Mexican variety, bred at first in Texas, but now proving to be adapted to a wide range of conditions in other states. Durango is distinctively earlier than Webber 11-4-inch or Columbia $11-4$, and has given better results than gated sections of the Southwest, and in the upland districts of the S outheast. The principal Long Staple Cotton as used in Mexico. Very early-one-third of it picked out at Augusta in August. Big boll, easy to pick, and has been grown in immense amounts about Augusta during the past two years. Augusta grower says: "Earlier than Cleveland, one week to 10 days." J. C. L., Augusta, says: "Great success for two years with Durango and averaging one bale to acre." J. B. W. says: "Have never seen cotton fruit so and make so fine a crop." W. B., Ga., says: "Will make as much and is as early as any cotton in the country." Even as far north as Norfolk, $\mathrm{Va}$, it has been grown on a commercial scale for the last five years, about 1,600 acres being planted in the season of 1916. Durango is very prolific. Has a distinctive, strong quality of staple, and has found a ready market, with substantial premiums above the regular prices for short cottons. Some 20,000 bales have been grown in the Imperial Valley of California this season by outyielding short staples. Its earliness gives it extra advantage under boll weevil conditions. Boll is large, 60 to a pound. 50 per cent five-locked. Price: One bushel $\$ 3.10 ; 5$ to 10 bushels at $\$ 2.85 ; 25$ to 50 bushels $\$ 2.60 ; 100$ bushels $\$ 2.50$. "WEBBER 82, or 11/4-INCH" - (See Cut.) The most productive of all Webber strains. The leading staple cotton in S. C, today. 10 per cent more productive than old style Webber. Our seed from pedigreed seed. Large bolls. Yields lint often of $13-8$. Lints $333-4$ to $341-2_{e}$ Fairly early. We began picking this cotton in August. Many regard it as the most productive cotton in $S$. $C$. and its extra lint and price has greatly stressed this cotton. One

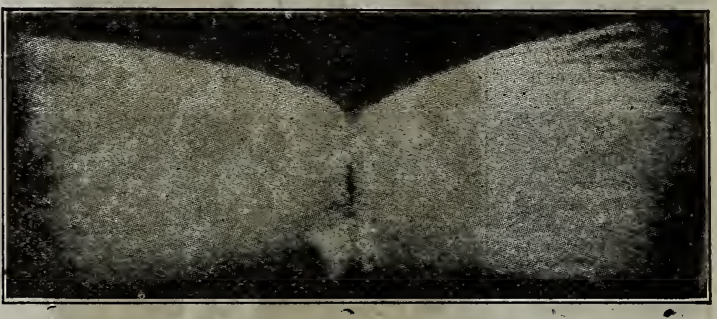

Webber No. 82 Lint.

grower here is making 350 bales this year. Says this cotton is better than Hartsville No. 11, being a better fruiter and that its yields are as good as short cotton. In $S$. C. is known as making the largest high-grade strong fiber of all big boll cottons. We saw on one stalk of Webber 82 this year 195 big bolls. Price: One bushel $\$ 310 ; 5$ to 10 bushels $\$ 2.85 ; 25$ to 50 bushels $\$ 2.60 ; 100$ bushels $\$ 2.50$. "COULETTE" LONG STAPLE, 1 5-8-New. This cotton is being listed and by us, for the first time. It has been bred out of the 'old Allen's, Floradora and Sunflower upland long staples. South Carolina grows more upland upland long staples. South Carolina grows more upland long staples (as she d res Sea Island) than any of our the very best of these cottons. The upland long staple buyers of S. C. are unanimous in declaring that Coulette's not only pulls longer-usually 15-8-but that it also carries a stronger and a better fiber than the old-time upland long staples. It is, a late cotton, but outside of the boll weevil territ $/ r y$ it is a most profitable cotton to grow. It is as productive as other cottons, - and carries usually $\$ 4$. to $\$ 50$ a bale premium. Price: Ona bushel $\$ 3.35 \cdot 5$ to 10 bustels $\$ 3.10 ; 25$ to 50 bushels $\$ 2.85 ; 100$ bushels $\$ 2.75$.

\section{Extra Long Upland Staples.} LATE MEDIUM BOLLS.

NOTE!-These 1 1-2 and 15-8 upland long staples, and long known in the South, can not be grown in boll weeril sections becarse they are all late cottons. This has produced a scarcity in these seeds. The boll weevil in South Georgia in all Sea Island land-thus cutting short this crop - stresses the value of these upland long staples, especially of the Coulette type, as never before, and they are largely indicated for non-boll weevil sections.

ALIEN'S IMPROVED LONG STAPLE-This cotton before boll weevil days was, outside of the Sea Islands, our principal source of supply for long staple lint. Immense amounts of it were raised in Miss., with lint running from 1 1-2 to $15-8$. This territory in Miss. now under $b, 11$ weevil can not raise it. But it is being raised to great advantage in territory not infected with weevil. Price: One bushel $\$ 3.10 ; 5$ to 10 bushels $2.85 ; 25$ to 50 bushels $\$ 2.60 ; 100$ bushels $\$ 2.50$.

FLORADORA LONG STAPLE-1 3-8. A late long staple akin to Allen's. In large use a few years ago. Price: One bushel $3.10 ; 5$ to 10 bushels $\$ 2.85 ; 25$ to 50 busheis $\$ 2.60 ; 100$ bushels $\$ 2.50$.

\section{SEA ISLAND COTTONS.}

SEA ISLAND-(Gossypium barbadense L.) - 42 pounds bushel. Extra long staple; lint $13-4$ to $17-8$ inches. Seed black and lintless. Plant $1 / 2$ bushel to the acre in row-5-foot rows, 3 feet drill. The famous Sea Island cottons of the South Carolina coasts are known all over the world. We get our seed there. While planted sometimcs 75 miles in the interior, yet seed must come regularly from coast or lint grows much shorter. R'ller gin is used, lint slipping the seed. Product of this cotton is usually twenty 
350-pound bales on 25 acres. Tall bush; yield about 30 pounds lint per 100 pounds seed. This lint brings now poc to $72 \mathrm{c}$. It is almost indistinguishable from silk.

WILT-RESISTANT EARLY EUREKA SEA ISIANDThe earliest Sea Island and wilt-resistant. An earlier The earliest Sea Island, and wilt-resistant. An earlier weeril areas with the late types only one-third crop under best conditions can be expected. Eureka has proren to be an earlier cotton. Furthermore Sea Islands are subject to wilt just as much as other cottons, and this cotton has been bred to wilt resistance. This gives this cotton extra value This Sea Island was bred and dereloped in the famous Edisto section of Carolina, and we get it there from the rery best producer. This cotton grades "fully fine", rields at gin $35 \frac{1 / 2}{2}$; exceptionally early, hardy. The grower says that in 38 rears in Sea Isiand experience, he nerer saw a better fruiter, and has never seen a withered stalk on his wilt land. This cotton carries 2 -inch staple and is by long odds the best of our Sca Islands for South Georgia and Finrida to plant. Price: Cne bushel $\$ 4.00 ; 5$ to 10 bushels $\$ 3.75 ; 25$ to 50 bushe's $\$ 3.50 ; 100$ bushels $\$ 3.35$ Fer bustel.

OTHER COTTON TYPES

Besides the above cottons we can supply Peterkin, Bank Account, Cooks, Columbia, Herlong, Russell, Truitt, Mortgage Lifter, Poulnot, Poor Land, Christopher, Half and Half, Dongola, Texas Oak, Hartsville No. 11, 1 1-4 ; Keenan 1 1-4, and Trice. State amounts you want.

\section{Forage and Miscellaneous Field Seeds}

MAKE EVERY IDLE ACRE BEAR FORAGE CROPS.

"Leguminous Crops in North Carolina." -Write for this bulletin to N. Car. Dep. of Agri., Raleigh, N. C.

Green Legumes Turned Under-Five tons of green foliage will yield in pounds nitrogen for s sil nutriment, as follows, riz.: Cow Peas 37 pounds, vetch 55 pounds, crimson clorer 46 pounds, velvet beans 54 pounds, Soys 65 pounds, alfalfa 74 pounds and Burr Clover 85 pounds. L.egumes, as turned under, equal Chilean nitrate; and their humus as a water holder and conservator, equals the direct rains of hearen. Build up your lands by filling in the middles of your clean cultured corn and cotton lands with legumes. We can increase by 25 per cent the yield of succeeding non-leguminous crops both in grain and straw, by turning under the leguminous crops.

\section{COW PEAS (Vigna Unguiculata) (60 lbs.} bushel.)

Use Mulford's Cultures. One-acre size $\$ 1.50$, postpaid; 5 -acre size for $\$ 5.00$.

One of the greatest soil improvers. A great economy rop.

There is an enormous increased use each sear for Cow Peas, Velret Beans and Soy Beans. The South must abolish her Northern has bill; also her guano bill; she must make two crops on her land in place of one per annum. All of the above can be accomplished by using Cow Peas, Siy Beans or Velvet Beans. In grounds rich in nitrates Cow Peas will make big vines, but few peas. Yield in peas 10 bushels (in corn) to 15 bushels (drilled) per acre. Freight on Cow Peas-Freight on Cow Peas, Velvet Beans and Soy Beans takes a " $D$ "' grain rate in So. Class, car or less.

GEORGIA COW PEAS-Augusta is the largest pea shipping point in America. This house is one of the largest pea jobbers in the South. We ship from Norember 1 st to July 15 th. Plant from early spring to July 15 th. Drill, broadeast or between hiils in corn. Broadcast $1 \frac{1 / 2}{2}$ bushels, drill 3 feet rows 1 bushel, or in corn rows $1 / 2$ bushel per acre Early planting makes vines, late planting makes

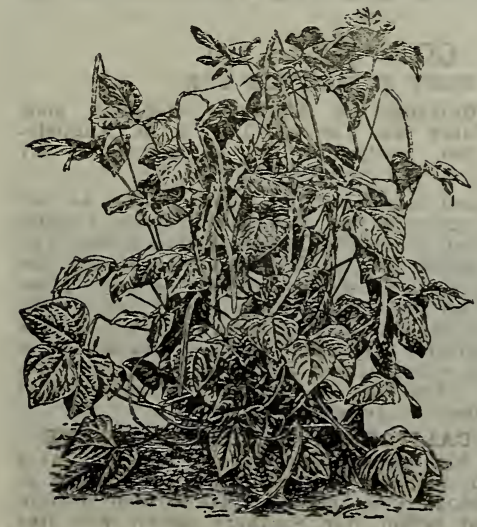

Cow Pea Plant. peas. Makes an excellent mixture to plant with Soy Beans, Sorghum, Kaffir Corn, German Millet and Japanese Millet. "Hog" A p r i l plantings in July, Tune plantings in September a $\mathrm{n}$ d October. Their best habitat is about us here The South's best friend. The clover of the South. Contains $m$ o $r$ nutriment as hay than clorer or al. falfa. Grow in poorest soil. Inraluable for hay, peas and soil renorator. Georgia per acre, 25,256 pounds green has, or 5,000 dry. For hay, cut when peas are forming and cure. Their full importance to Southern agriculture has not yet been realized. Large yearly increase in use, and extending now to Northern States. Augusta often gathers by July 15th, a crop of New Era, Ramshorn, Iron and Brabham Peas. A big winter-gathering money crop. Cow Peas have lon bcen a leading crop in the South for hay and pasture; and the green peas are staple human food throughout the summer season. In winter the dried peas are just as good as white Nary Beans.

PEAS IN A BUSHEL Count out as follows: Unknown 143,000; Whipps 157,000; Clay 161,000; B. I. White and Ramshorn 159,000; Peerless 165,000; Miller 207,000; Iron 230,000 ; New Eras 234,000; Brabham 236,160; Little Lady 301,000 .

THE FOUR BEST PEAS-Out of 220 types, Cow Peas tested by United States Agricultural Department, they say the four best are: Whippoorwill, Iron, Brabham and New Era.

FALL AND WINTER SOWING OF COW PEAS-Iron, Miller and Brabham can be fall or winter sown along with grain. Sow peas before breaking land. Break land deeply, then drill oats, barley or wheat; or harrow same in. Peas will come up in the spring. In mowing the grain in the out and produce more largely.

IRON, also called FLINT-A small, hardy, gravish-vellow, glassy or shiny pea, known sometimes as Buckshot. Exploited widely by United States Agricultural Departmen as being immune to root knot caused by eel worms. This pea is, therefore, an invaluable addition to the pea world is small and one bushel of it will go as far as one and a half bushels of the larger peas. It is tough and hard, and, therefore, largels weeril proof in the barn and in the pod in the field. The rine is resistant to cold; Iron and Brabham pea rines will stay green until frost; can be "picked" six or seven times, and vine then cut for has. Peas in pods in fields will remain undamaged until late picked. This is possibly the most valuable field pea today in the world. Being a root knot resistant pea, this pea, in preference to others, should be planted in all peach orchards and in the Sumatra tobar folds of Florida Earlier than Unknown. After rains often bears a second and sometimes a third After rains often bears a second and sometimes a third crop. Does not shed till peas are matured; therefore, suhere July 1st, in drill, grew 28 inches high and 36 inches broad in row; branches were 4 to 5 feet long, were immune to rust. Matures in about 100 dass. April plantings Augusta matures crop about Juls 20th, and ripe peas can be gathered, the rines can be cut for has, and by cultirating the stubble, the stubble will grow out and make the rating the stuble, the stubble will grow out and make the other pea will do this. Quart 25c. Larger amounts, get price

BRABHAM-New. First listed by us. Known as "Speckle Rio" - 60-day two-crop pea. A hybrid of Iron has the earliness of the Whippoorwill, and the wilt-resistant qualities of the Iron. Is as resistant to-wilt as Iron. A small, hard, speckled pea about the size of Iron and New Era. Will make two crops. Agricultural test at Washington, yield from Brabham 20 per cent more hay than Iron 27.1 bushels of seed as against 15.6 of Iron. than Iron and 27.1 bushels of seed as against 15.6 of Iron. A Florida grower says: "Brabham peas made the finest lot of vines I erer saw." This is practically the New Iron pea. As the New Era in the middle portion of the United States has taken the place wholly of the Whippoor will, so when stocks can be had, the Brabham, on account 
of its wilt-resistant qualities, will supplant in turn the New Era. This is the most valuable pea today in America. On account of its size, one bushel will go as far as one bushel and a half of the larger peas. Vigorous, prolific seed, hard, and retains vitality. Hold leaves better than others. Can be planted with fall grain, will lie in the ground all winter, and will germinate next spring. A Florida grower says: "My 20 acres of Brabhams made an aston. ishing amount of vines which were cut for hay and from the stems a second crop came which made a full large crop of peas." Sown here in ensilage corn, at laying by we cut corn with binders in August. We cultivated peas in knocked out middles, peas meeting in 5 foot rows. The originator reports the U. S. Department of Agriculture as saying: "This pea makes more vines than any known pea." Pods white and $6 \frac{1}{2}$ inches long about 18 peas to the pod. Brabham peas and Abruz zi Rye furnish an almost complate all the year proposition for hogs for "hogging." Iron and Brab ham pea vines will stay green until frost; can be and vine then cut for hay. Quart 30c. Larger amounts get price.

PEERLESS-Formerly known as "'Running Speckled." Pea is hard, does not stain, and color is lighter and more shiny than Whippoorwill; pea is longer, too, and very slim. Large, long, yellow hull average 12 inches in length. Does not rot so easily as Bush Whips. State College, Agricultural Department, A thens, Ga., reports: "Maturity, Peerless, October 1st; Whippoorwills mature August 20th. A less, October 1st; running pea with same large growth as Wonderful. Stood at the head of the list in point of hay yield, making 2.64 poorwill, 2.36; Wonderful, 2.27. Heavy foliage and large stalks, and is entirely a different pea from the Bunch Whippoorwill.' Unknown except in Georgia, where it originated. Today Georgia grows it -largely as the best forage pea, It must not be confounded with Whippoorwill peas. Planted in corn it covers tallest stalk and makes abundant peas. Some say one quart to the stalk. Easily threshed. Fine for eating green-shelled. Quart 25c. Larger amounts get price.

WHIPPOCRWILL, or SPECKLED, or SHINNEY, or BUNCH SPECKLES (two-crop peas)-Out of 220 varieties of Cow Peas tested by the U. S. Agricultural Department, they they say that the best four are: Whippoorwill, New Era, low pod, thick and rots easily, brown spotted pea. Earliest low pod, thick and rots easily, brown spotted pea. Earliest of all peas; liked in the North; not much vine to it; grown middle of Aurust. Mottled chocolate in color. Pea is darker and shorter than Peerless. On account of extreme earliness and before advent of New Era universally used in Northern latitudes and of tremendous use even today. Whippoorwill Cow Peas are now largely planted in the middle of cotton rows in mid-summer; and the vines are turned under and next season cotton is planted where peas were. Quart 25c. Larger amounts get price.

NEW ERA-Two weeks earlier than Whippoorwill, and one-third smaller. A bunch pea, erect. Ripens six to eight weeks, recommended where early maturing cow peas are wanted. Universal pea now used in Missouri in wheat stubwanted. Universal pea now used in Missouri in wheat stubJuly; has supplanted the Whippoorwill." Experiment StaJuly; has supplanted the "Whippoorwill." Experiment Sta-
tion, Arkansas, says: "New Era made 45 bushels per acre peas; Whipps, 27 bus.; Unknown and Clays, 6 bus.' New Era has 246 peas in an ounce, Whipps 137 peas in an ounce; hence, 40 pounds New Era will plant as much land as 60 pounds Whipps or Unknown; one-half bushel in a drill plants an acre. Introduced near Augusta, Ga., seventeen years ano Three crops were made one year at Georteen years ago. Three crops were made one year at Georthis is the most valuable pea today known in America; often this is the most valuable pea today known in America; of ten
matures in 60 days; bluish color; smallest seeded of all the cow peas, most easily handled by machinery, as in Missouri. April Augusta planting mature crop by July 10th. Vine holds color after peas ripen. Plant never falls down. New Era are seven weeks, two-crop peas, earliest pea grown. Quart 30c. Larger amounts get price.

UNKNOWN, or WONDERFUL, or BOSS-Finest combination pea for heavy vines and stock peas. Stands at the head as per U. S. Agricultural Department as "largest growing and most vigorous cow pea", Erect vines; late maturing; pale buff color peas. Seed large in size, and $\operatorname{lic}_{i \rightarrow 0}$ क्या , large in size, and 
two crops. Larger in size of peas and growth of vines than the usual Blackeye, and quicker to mature. The vine is exceedingly large, and the peas are exceptionally fine yielders. For table use the peas are more attractive and larger and sweeter than Blackeye, and curved up at both ends, sugary, and skin is a little rough. The best Blackeye pea known, and for table use this new pea will prove of immense value. Quart $40 \mathrm{c}$. Larger amounts get price.

BROWN EYE-Medium to large; white with brown eyes; universal table pea; good eater; largely. used in the South; rots easily in the pod; medium late. Quart 35c. Larger amounts get price.

LITTLE LADY-Bunch; has a delicate vine; very prolific bearer; the finest of all the white table peas; very sugary. The daintiest, -smallest and most highly prized of all the white peas for the table. Quart $45 \mathrm{c}$. Larger amounts get price.

CONCH, GENTLEMAN SEMINOLE, Or EVER-BEARING PEA-A small, pure white table pea, delicate and delicious. Profuse bearer. Planted in April begin bearing late in June, and vine bears continuously until frost. Pods brittle. The pods can be eaten green like snap beans, or the pods can be shelled for green peas, or dried peas can be saved. The more the pods are pulled from the vines, the more quickly and the more largely the successive crops come on. quickly and the more lants to the hill. Will run in every Plant $4 \times 4$ feet, two plants to the hill. 8 feet and cover prone all the ground. direction about 8 feet and cover prone all the ground.
Vigorous growth. Two quarts should sow an acre, and one quart will make enough seed for a family to consume at the table from June till frost. In large use in Florida-originally came from Seminole Indians. Quart 50c. Larger amounts get price.

CANADA FIELD PEAS-Small, round, smooth, whiteseeded pea. Used for cummercial purposes or-sown with other grains for feeding purposes. Height of straw 48 inches. Resembles a small extra early garden pea. Takes the place in the far North and Canada that the cow pea dues in the South. Not so resistant to hot weather as cow does in the south. it will stand most any temperature. Valuable hay and forage plant for the Southern farmer, because it grows at time of any time from September until March. Sown alone, broadcast like cow peas, at the rate of a bushel to a bushel and a half to the acre, and will afford fine grazing within 90 days after sowing, or allowed to mature will produce a valuable crop of hay of high feed value. Canada field peas valuable crop of hay of high feed value. Can up peas. Combination makes a perfect forage. Cut when oats just begin to turn. It makes large out-turn. Makes the very best of hay. Are also fine for the table; can be used for such until the crop is cut. Price fluctuates. Price: January 1st: Peck $\$ 1.75$; bushel $\$ 6.00$.

\section{SOY, or SOJA BEANS}

\section{GLYCINE HISPIDA- $(60 \mathrm{lbs}$. to bur. $)$}

Use Mulford Cultures-for Legumes-One-acre size, $\$ 1.50$ postpaid; 5 -acre size for $\$ 5.00$, f. 0 . b. Augusta. Also $1 / 4^{-}$ acre 50 c postpaid.

THE SOY BEAN-(Uses and Cultures.)-Soys carry more varied uses than any other plant; lead all other crops in production of digestible protein-exceeding corn 100 per cent. After threshing must not be sacked or piled per cent. After threshing must not be sacked or piled age and feed crop for Southern farmers. Carry superiority orer cow peas; carry wide uses in forage, pasturage, hogging, soil renovation, hay, cash crop, oil cake and canning (dry peas). Resist drought and cold better than cow peas. Can plant both later and earlier than cow peas. Sow at corn sowing time. For green manuring broadcast. For hogs, broadcast last cultivation of corn. Sow spring or summer. Sorghum, Sudan or Cow Peas all make good mix-

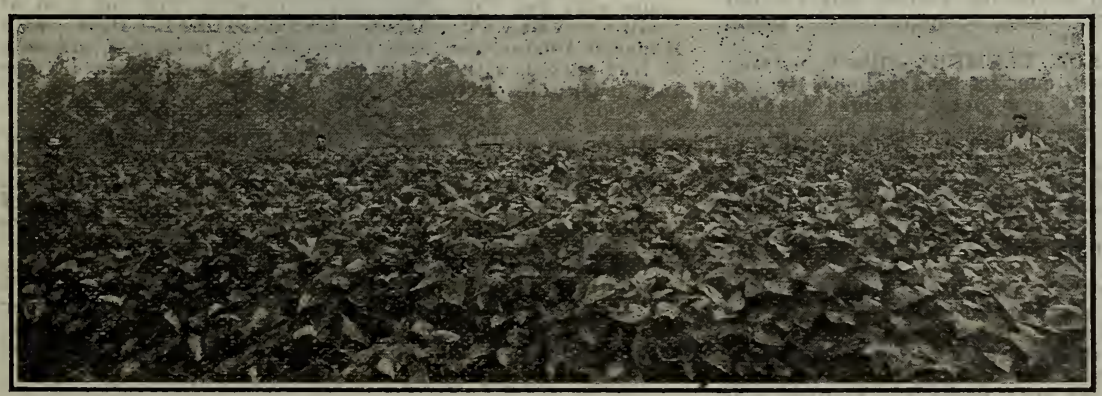

Soy Beans Neck High. tures with Soys. Yield 20 to 30 bushels per acre-far more t? an cow peas. For seed, drill $1 / 2$ bushel in 3 -foot Weevils do not attack. For hay or green manure, broadcast 1 to $11 / 2$ bushels per acre, or drill. Vines can be cut and seed beat out with flail. Can sow after oats for hay and make 2 to $2 \frac{1}{2}$ tons per acre. Broadcast at last corn plowing in corn and then will lie on ground up till February for hogs. Fine for hogging. For forage cut the vines when the beans just begin yellowing, save and feed

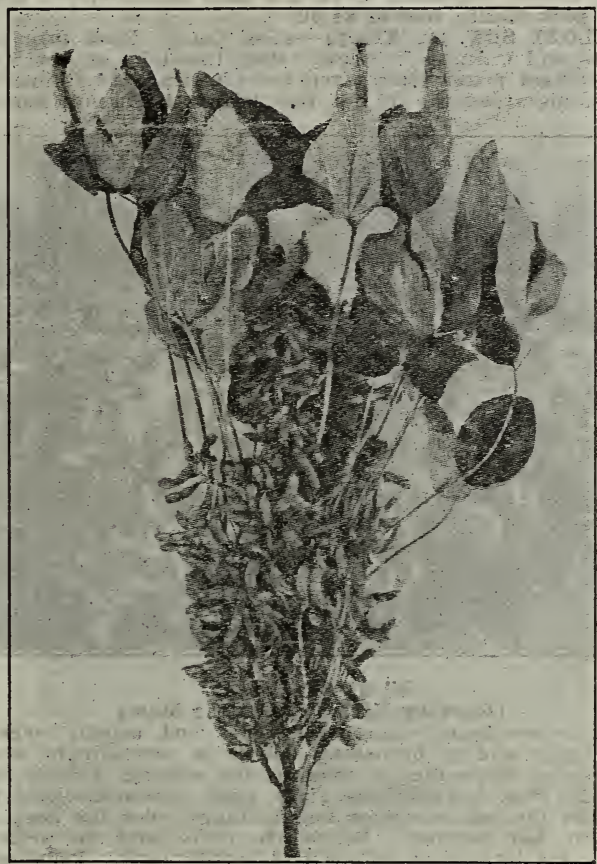

Soy Bean.

this combined ration of Beans and Vines. Sow with cow peas, to hold the vines up off the ground, so as to enable them to be cut and cured to better advantage; where sown with cow peas, sow at rate of half a bushel of Sojas to one bushel of cow peas. The combination is excellent. Soja Beans, forage and beans are very nutritious, containing more oil and fattennig properties than any other similar crop. The only crop that furnishes a balanced ration in one crop. Not necessary to feed corn, cotton seed meal or any oil-foods whatever when feeding Soja Beans. On sandy poor land 3 feet high. Each pod carries three beans and possibly 200 pods per stalk. Seed ripen at same time. Do equally well on light and heavy soils. A fine land im. prover. Yield is heavier in beans and vines than cow peas. Are easier raised, more productive, carry more nitrogen, hay is easier saved, and beans are easier threshed, and require only half as much seed as cow peas. As a source of protein, there are few things better. The pressed oil is not only edible, but is our best linseed paint oil substitute, also a solvent for cresol. The pressed cake is, for stite, also a solvent for cresol. The pressed cake is, for Being a bush-like plant, Soy Beans do not interfere with the cultivation of other crops when sown in the middles. Plant in corn middles and then thicken the stand of your corn in the cor row and get two good crops. Always inoculate seed. Fine in orchards. In Fine in orchards. In ing - 2,000 pounds Soys make 1,650-1b. cake and 30 gallons of oil. The $\mathrm{U}, \mathrm{S}$. is importing this year over last year, and free of duty, three times the amount of Soy Beans and Soy oil

MAMMOTH YELLOW SOY - Read foregoing "Uses and Eultures." Soy Beans. More large. 
ly planted than other varieties. Has produced in North Carolina and Tennessee in large areas an average of 40 bushels per acre. A medium late variety and usually a sure crop. Growers at Augusta pronounce inoculated Soys as making more pea forage per acre than cow peas; and say making more pea forage per acre than cow peas, and say green bean seeds make, a delicious cooked vegetable akin to green peas, and are canned with great ease. For canning Yellow Mammoth Soys are

BILOXI SOY (or Tracy)-(See Cut.) Read foregoing "Uses and Cultures." New. Only listed by us. A Miss. Government tester after seven years testing 100 China Soy types, discarded the 99 for this bean. Different from all

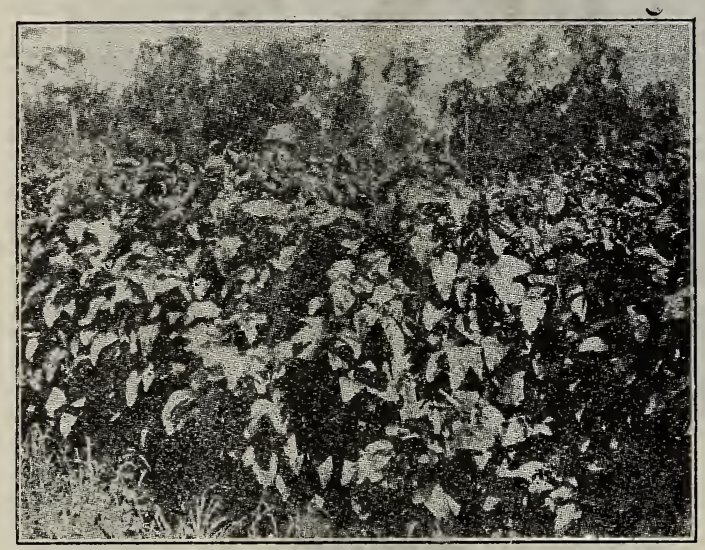

Biloxi Soy Beans.

(Growing Neck High to the Man.)

other Soys-larger than other types and usually over 6 feet high; widely branching and with exceedingly much foliage-so large that it requires for cutting, a corn harvester. This extra foliage gives great advantage here for
the silo, for soil renewing and turning under for hogging, the silo, for soil renewing and turning under for hogging,
and for hay making. Beans are extra high in protein. Stems are large, but hollow and, easily cure. Pods scatter seeds very little. For maturing seed, plant April or May-requires long season. For hay alone, or with cow peas, can plant even in July. Two weeks later than Mammoth Yellow. On account of rank growth one bushel plants 5 or 6 acres - three-fourths bushel as broadcasted. Give distance ábout like corn. Yields 20 to 25 bushels per acre. Seeds are large and red. Price: Quart 35c; peck $\$ 1.75 ;$ bushel $\$ 5.75$.

BROWN SOYS-Read foregoing "Uses and Cultures." A brown bean; as large as a cow pea, that has white tracings over it. Mature about like Yellow Mammoth, but are more prolific. We counted this season one stalk with 447 pods to one stalk, making a larger growth of vines and a better yield as regards the bean. Many North Caroand a better yield as regards the bean. Many North Carolina farmers broadcast brown soys in corn, and say they Quart 30c; peck $\$ 1.25$; bushel $\$ 4.00$.

HOLLYBROOK SOY'S-Read foregoing "'Uses and Cultures." Grow 25 to 36 inches. The branches are nearly as long as the main stem. Pods thickly set on the stems and branches. Seed medium in size, of a deep lemon yellow, and very shiny. Hollybrook will mature in 90 days. The pea is smaller than Mammoth Yellow, has a pinkish tinge; is inclined to be a dwarfish bean. The bush is poddcd right down to the ground. Hollybrooks are two or three weeks earlier than Mammoth Yellow, but are not $40 \mathrm{c}$; peck $\$ 1.50$; bushel $\$ 5.00$.

MAMMOTH EARLY BIACK TARHEEL-Black, notably free from disease and insect enemies and supposedly immune to the wilt that affects cow peas it makes a creditable yield hay and beans in a short growit makes a creditable yield hay and beans in a short grow-
ing period. The Tarheel Black Soy is earlier than the Mammoth Yellow, and gives more prolific growth and larger foliage. It is a better yielder of seed. For hay purposes it is far better than Mammoth Yellow. Early, ready to cut in 90 to 100 days. Beans 20 per cent larger than Mammoth Yellow. Popular in North Carolina. Price: Quart 30c; peck $\$ 1.25$; bushel $\$ 4.00$.

MIXED SOYS AND COW PEAS-For hay and forage; better than single soys or single cow peas. Mix half and half, and broadcast. $1 \frac{1 / 2}{2}$ bushels mixture per acre. Cure as pods begin yellowing. Makes more hay, far-more easils cured, and is a better ration than cow peas alone. In curing, the upright plant of the soys keeps the trailing cow pea vine off the ground; and as a ration, the beans of the Soys, as eaten with hay, gives double value. No better hay on earth, and no hay more easily cured than this mixture. Get prices.

\section{VELVET BEANS.}

VELVET BEANS-Uses and Culture. ( 1 bu. 60 lbs. shelled; 100 lbs. of pods shell out one bushel beans.) We are large dealers and contracting growers, and the leading exploiters of new types in South. Velvets are the most vigorous and rank growing annual forage legume in the U. S., and a most important crop carrying wide uses. The early types are adaptable wherever cotton is grown. A big cash crop in boll weevil lands. A crop that will make the South the center of the U. S. cattle industry. Ga. and Ala. alone now grow $3 \frac{3}{4}$ million acres in velvets. Have an immense surface root system (sometimes $20 \mathrm{ft}$.), and with big nitrogen nodules. CATTLE FEED-Pick the bunches of dry pods by hand (about 700 pounds a day), in winter after frost; and well dried they keep, piled in fields, and keep in pod indefinitely, in barn; and are sold largely carlots loose, for cattle feeding. One acre yields one ton dried pods shelling out 20 bushels. An immense industry is the grinding of velvets-in-the-pod as a commercial cat tle feed-making cheapest and possibly the best of concentrated feeds - one pound equalling one pound of wheat bran, or one pound corn on cob, or half pound best cotton seed meal. Or feed cattle and hogs velvets in pod, whole and dry; or soak pods over night; or for dairy, steam them. The green undried pods are edible and relished. WINTER GRAZING-Af ter hard frosts turn cattle and hogs in fields to same up to March. Vines and beans equally likedthey clean up the whole business. Nothing equals this crop for winter grazing protein crop; it spells ing protein crop; salvation to Southern cattlemen or hog men. $10 \mathrm{ft}$ or more, and up a tree or on arbor, $50 \mathrm{ft}$. An acre of Georgia velvets is as good as an acre of $\mathrm{Ne}$ braska alfalfa. For forage, soil renewing, or seed production velvets are worth two to four times more than cow peas. Make hard hog flesh. Grazing winter velvets is as cheap a food matter as is a green summer pasMENT-For soil building and immense humus mak. and immense humus mak-

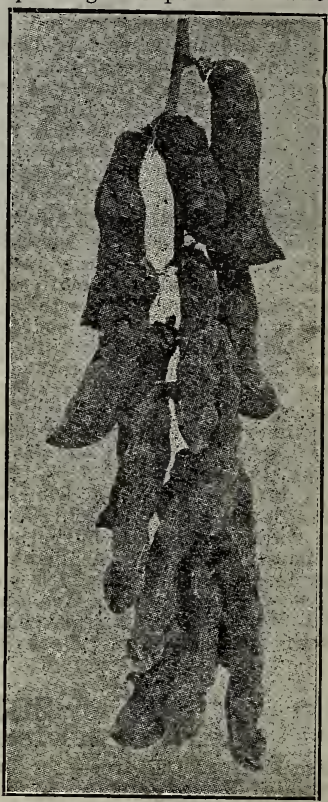

Bunch of Velvet Beans. vets. One acre velvets turned under adds $90 \mathrm{lbs}$. nitrogen per acre, and increases succeeding crops on the land as follows: Corn 12 bushels, Oats 17 bushels, Cotton 200 pounds lint. The good of this nitrogen and humus lasts four or five years in the soil. CULTURE-Plant in cornthe corn stalk is its best support; gives always a double value to the corn crop. Plant corn early and when nearly vnee high. plant two beans in the row beside knee high plant two beans in the row beside; each stalk; or plant in middle of corn row every 24 inches; or plant two rows of corn and one of velvets; or between seven feet corn rows plant one row of peanuts and one of velvets. DISEASE RESISTANT-Weevils do not at tack. Immune to root-knot and wilt diseases-two velvet crops with two fall grain crops following will rid land of Mint. Monarch Duster, per acre three pounds powdered arsenate of lead mixed with 12 lbs. air
only after one or two rains.

DIXIE VELVET BEAN HULLERS-(Also hulls cow peas and other commodities, ) Dixie Huller No, 5, 3-horsepeas and other commodities.) Dixie Huller No. 5, 3-horsepower, weight about 650 lbs. No hand power machine can
be made available for hulling the stiff-hull fuzzy type of velvet beans. Capacity 80 to 100 bus. per day. We have been selling this machine for 12 or 15 years with the highest satisfaction. Where the picked Osceola beans are to be shelled, we fit up a special machine which will hull Osceolas and Chinese, to be run at 250 revolutions per minute. The same machine will negotiate the 100-Day, minute. The same machine will negotiate the but must be
Price, $\$ 140.00$.

TO DISTINGUISH WHITE VELVET BEANS-Chinese are white, plump, large. Lyon bean is flat, squarish and size of Sievas. Yokoliama bean is smoky, dull white, dented, oval. 
GEORGIA 100-DAY SPECKLE VELVET BEAN-Introduced and named by us. Originated in Georgia, some-

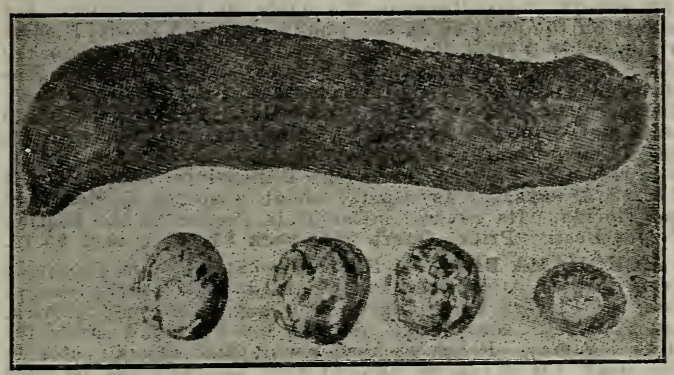

100-Day Speckle Velvet Beans and Pod.

times called the Georgia Velvet Bean. Bean resembles late Fla. Speckles, but is larger and lighter in color. A most valuable extra early Velvet-vines and beans worth double

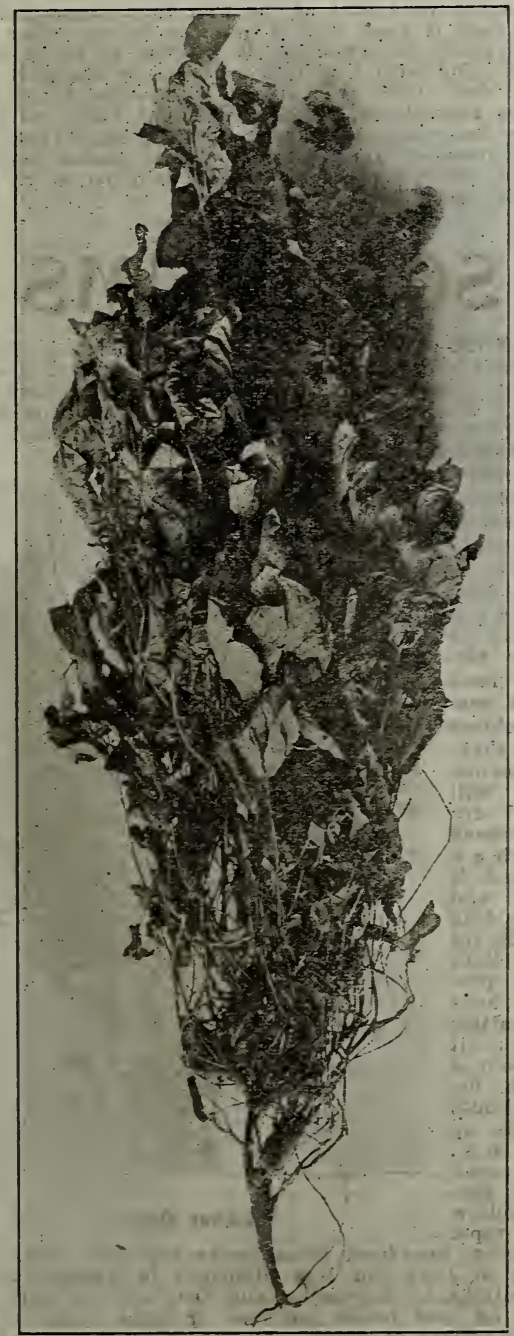

Georgia Bush Velvet (Root System Broken Off).

cow peas. One Augusta vine this season showed a length cow peas. as trained on a string of 30 feet, carrying in some cases
20 pods to the bunch; pods usually contain four beans and are 25.8 inches long. Plant spring or summer. Can plant after oats and use in time before fall oat planting time, as a quick September grazer; or for turning under for soil manuring.

These beans-in-the-hull are being largely ground up alone, or in connection with corn in the shuck, making a perfect ration in Southern cattle food. Plant 3 feet apart in corn middles in 5-foot rows; or alternate with corn in the row. meses. Make one Read above, ton beans-in-the-pod per acre. This bean is attracting wide attention and seems to solve for all sections the elvet
Bean question. Fully matured and threshed for seed purposes in middle North Carolina. One bunch at Augusta showed 24 pods with 112 beans. 100 pounds of beans in the pod shell out 1 bushel. The big bunches are easily gathered.

Yield 15 to 20 bushels shelled per acre. Planted in corn usually make more bushels of shelled beans than corn. Has the following adrantages orer the cow pea: Its seed cost is 75 per cent less; it is not attacked by weevils; it makes two or three times more rines than do cow peas; it is a larger and better soil renovator, and a larger and bette fall grazing matter; its pods are ground up (pods and beans); it is gathered more easily than the cow pea, for a man can gather 600 pounds a day and each acre ought to turn out about one ton of beans in the pod worth so. The meal is 19 per cent prot The meal is 19 per cent protein, 5 per cent rat, and 51 per cent carbohydrates. The bunch of 100-Day Speckle Velvet Beans, as shown in the photo, was taken when green. The
bunch carried 36 pods and weighed green $21 / 2$ pounds. bunch carried 36 pods and weighed green $21 / 2$ pounds
Note! The "Alabama 100-Day Speckle Velvet", is three weeks later than the "Georgia 100-Day Velvet.", The must not be confused. Seed look alike. Price: Quart 25c peck $\$ 1.00$; bushel $\$ 3.00$

GEORGIA BUSH VELVET BEAN-New. Only listed by us. See Cut Named by Mr. Willet, who has interested b us. See Cut. Named by Mr. Willet, who has interested U. S. Government in this new product. A wholly distinct and new velvet bean which carries most valuable and years ago. The bean is a bush bean and not a twining bean. The cut shows an upright bush $3 \frac{1}{2}$ feet high with limbs all branching from the bottom and with beans mostly near the bottom. Planted in the middle of $5 \mathrm{ft}$. corn rows it fills the whole middle, but does not twine or ever strangle the corn. Should be planted late in April in corn mid. dles rather than in corn rows. It grows up and stands sturdily as a bush. Beans and its small pods look like the Georgia 100-Day; but its growing and maturing season is three weeks later. In growing it needs three ft. space stands drought better than other velvets; carries a big root system. Stands alone and can be used finely for hay for its stems are hollow; it is not woody, therefore; and being bushy and not twining it cures excellently. For winter grazing, stock like it far better than the twining trpes. For hay purposes it can be planted to June 15 th. South Georgia growers assert that this bean will largely increase relvet bean growing; and it wil give us a type of bean carrying absolutely such new uses as will add largely to the value of the velvet bean industry. Price: 1 quart $50 \mathrm{c}$ peck $\$ 2.50$; bushel $\$ 8.00$.

CHINESE BEANS-(See Cut.) - First listed by us. Medium early, white. Month carlier than Florida Speckled and more iree of caterpillars and frost, and one month later than and one month later than Ga. 100-Day Speckles. Rankest grower of all the
Velvet Bean tribe and of more value in soil improvement. From China. Florida Exp. Sta. says: "It is a heavier crop than the other velvet beans and ripens usually about a ripens usually about a month earlier than either the Fla. or Lyon. It consequently gets out of the good habit of growing vigorously at the start.

Planted four feet apart in corn rows, these beans produce large amount soil humus, and soil nitrogen, forage. Make 20 to 25 bushels shelled beans per acre One bunch at pucure 18 inches gusta fair 18 inches lon Velret Beans planted with Mexican June Corn, here at Augusta, after oats, good yield of corn wa

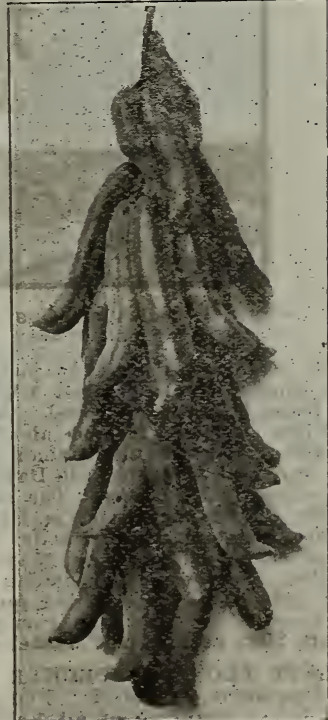

Chinese Velvet Beans. made, and-more forage for stock than any other crop ever tried on the land, Beans did not mature, but ihe irost- 
bitten,-immature beans were greedily eaten with the vines by cattle. Chinas make a world of forage for grazing after frost.

Beans are large, white, not gray, and ends are almost square; as big as butterbeans. Cattle men now plant in separate fields One Hundred Day. Speckles and Chinese, and get continuous grazing September to February 1st. At Augusta, with several inches of leaf mould in many places on ground, and as tall as the corn, and running 20 feet or more, Chinese made an impenetrable mass in the whole field, and it required four-horse plow to turn under. The pods are smooth and easy' to pick. China Beans in corn poit altogether is the most excellent thing yet known for cut altogether is the most excellent thing yet known for
silos. The feed content is excellent and the out-turn is tremendous. Price: Quart 30c; peck $\$ 1.35$; bushel $\$ 4.00$.

OSCEOLA VELVET BEANS-See two cuts. Only listed by us. A new hybrid from the Florida Experiment Station. Planted in Florida in May, were reaped in late September. The leaves shed about October 1 st, and this makes the bean pod and the corn ear gathering casy. Bean picking is less costly by $\$ 2.00$ a ton. Will make 20 per cent more beans than will the 100-Day. Blooms mostly purple Where beans in the pod for grinding up are wanted, this without doubt is the coming bean and will be in enormous demand. The leaves fall about October 1 st, and mulch the ground very heavily. At Augusta the Osceola was fully developed green, August 22d. On some bunches there were 21 pods. The vine out-turn is about the same as 100-Day. No fuzz on hull; cattle eat it better and it does not sting the pickers in picking. Does not pull down corn as badly as other types. Plant 24 inches in row with

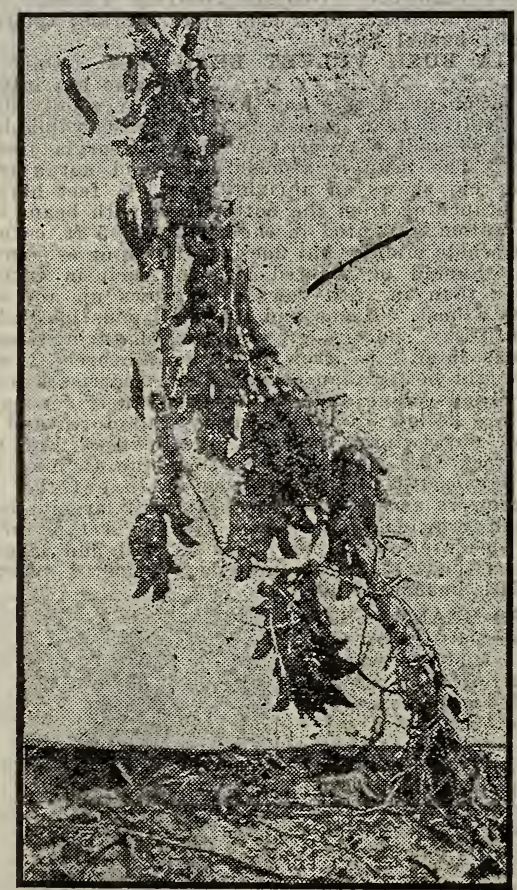

Osceolas on One Stalk of Corn.

corn. Our cut shows 216 pods to the one stalk of corn. One single bunch wegihed $13 / 4$ pounds green, and carried 23 pods, 5 beans to a pod. A trifle later than "Georgia 100-Day Varieties,", a pod. A trife later than "Georgia Chinese. Shatters more than fuzzy varieties. The beans are speckled like the 100-Day, but twice as large, being the size of the Lyons. The size of the pod is the same as the Chinese and twice as large as 100-Day. Pods are 5 inches long, carrying usually 5 big beans. The bunches often carry as many as 25 pods, and are often doublejointed, in many cases having two bunches to the joint. Big podded, big seeded, big forage out-turn, and with earliness - the Osceola Bean carries many advantages. Price: Quart 30c; peck $\$ 1.25$; bushel $\$ 4.00$.

IATE FLORIDA SPECKLE VELVET BEAN-(Mucuna Deeringianum.) Called "Florida Speckled", The oldest and latest maturing of all Velvet Beans, and only planted in Florida, Blooms till frost. Mature seed in 7 to 8 months in Florida. A big yielder-vine and pods. Late. Bean is speckled and round and small. Vine runs 20 feet.
Makes 15 to 20 bushels shelled beans per acre. Price: Quart 25c; peck $\$ 1.00$; bushel $\$ 3.25$.

LYON BEAN-(Macuna Lyoni.) Lyon Beans make as much cattle feed as Florida Speckle and stock prefer them and always choose them in the fields, as the dust does not collect on the pods as on the woolly podded Velvets. Blooms white, other Velvet Beans purple. Four to 6 beans to the pod. Seeds are white and inclined to be flat. Bean bunches often grow 2 feet in length and 40 to 50 pods to a bunch. Earlier than Florida Speckles, easier to pick and also to hull, makes more vine, and is a softer bean for cattle to eat. Beans smaller than Yokohamas and Chinese, white, flat, resemble Sievas. From the Philippines. The Florida Exp. Sta. says: "Is usually about a month earlier than Exp. Sta. says: "Is usually about a month earlier than
the Florida. Its general behavior is similar to the Florida Velvet Bean. Price: Quart 25c; peck $\$ 1.25$; bushel $\$ 3.75$.

YOKOHAMA BEAN, or SMOKY-(Stizolobium Hassjoo.) From Japan. Crop can be obtained two months earlier than the Florida Velvet Bean. For hay-making plant thick, say $2 \times 2$ feet. Grows well on soils too light and sandy for other legumes. Pecan orchard people find special value in this bean, for it can be planted very late and can be used or turned under before nut gathering time. Will mature heavy crop of seed in 100 days from planting. Can be grown successfully as far north as Arkansas. Moderate crops have matured as far north as Virginia and Missouri. Excellent grazing for cattle and hogs from about August until field is cleared. Plant same time as cotton, one peck per acre. Corn stalks are good supports. Growth of vine is not as heavy as that of the Florida or Lyon bean, but yield of seed is good, and it matures before either of the others is ready for grazing. Run often 10 to 12 pods to the bunch, and with 5 or 6 large beans to the pod. Vines 10 to 12 feet; pods are covered with white hairy matter. Seeds are ash-colored, often blackish at ends, oblong and flat, like butterbeans. Larger than Lyons. These beans make an immense crop beans. Pods are almost double the usual size. Should make 20 bushels seed per acre. Price: Quart 25 ; peck $\$ 1.25$; bushel $\$ 3.75$.

\section{SORGHUMS}

SORGHUM-(Andropogon.) (50 pounds bus.) The Sorghums make a larger yield in the same length of time than any other forage crop, with possibly the exception of Teosinte. The use of Sorghum as a forage crop has increased very rapidly. No food is more nutritious, or more greatly relish

ed by cattle. Should be one of the staple crops of every Southern farm er. An excel lent $g r$ e e $n$ feed. Can be cut over two or three times during a season, yielding two or three crops from one seeding. Will $\mathrm{s} t \mathrm{a} n \mathrm{~d}$ dry weather much better $t h$ a millet, and is a surer and larger yielding crop. Makes a n excellent summer pas ture for hogs a $n$ d cattle p a s t u reit when about a foot high, before it joints and sends up its $s \mathrm{t} e \mathrm{~m} \mathrm{~s}$ Makes excellent hog pasture to follow

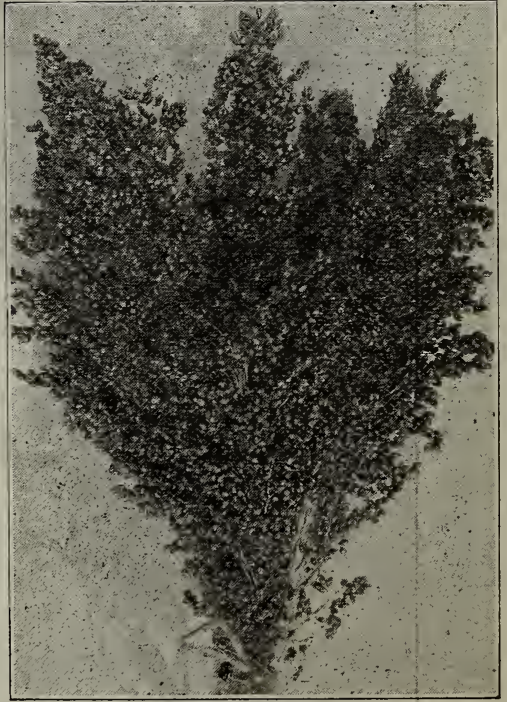

Amber Cane.
For hogging, broadcast three pecks per acre; graze April plantings in June and May plantings in August; and the July plantings in September and October. In syrup-making chop off seed heads and feed or make seed. One ton makes 20 gallons of syrup. The sweet sorghums and grain sorghum crops this year in U. S. somewhat a failure, which makes the seed high.

Culture-Plant from April 15th to August 1st. If in rows 3 feet apart 15 pounds to the acre, or broadcast, 1 bushel per acre. 


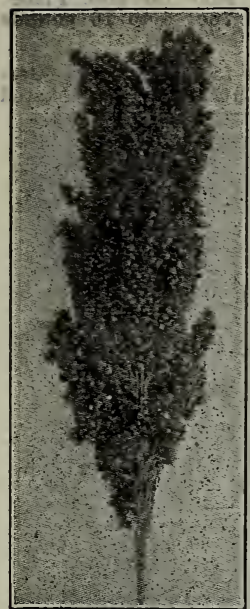

Head Early Orange Cane and better green forage than Amber. The standard. Better for syrup than Amber, and better for the shocking of ripened stalks for feeding. Earlier than Red Top. One pound 15c; peck $\$ 1.10$; bushel $\$ 3.50$.

RED TOP, or SUMAC SORGHUM-Stems sweeter and juicier than some other sorand go farther in planting. Hea gor planting. Yields about 5 tons per acre of forage. Seeds roundish and clean usually of hull. Medium early, 7 to 10 feet high. Leads all other varieties in portions of Tennessee and in North Georgia for syrup and forage; universally used and preferred seed bringing there a premium. About six days later than Orange. Stools well. One pound $15 \mathrm{c}$; peck $\$ 1.15 ;$ bushel $\$ 3.60$.

\section{GOOSE NECK SORGHUM-} Sometimes called "Crooked Head Texas Seeded." "Seed large as Orange, and in color the same; round in shape; never cleans well in threshing, but holds the outside hull, which is deep black. Largest of all sor- Head Red Top Sorghum. Stalks about $1 \frac{1 / 2}{20} 2$ inches at butt in diameter. Sow thinly for syrup. Later than any of the sorghums. Some plant in rows 3 feet wide and 18 inches apart, and 3 stalks to hill. Old growers say that it has the finest flavor of

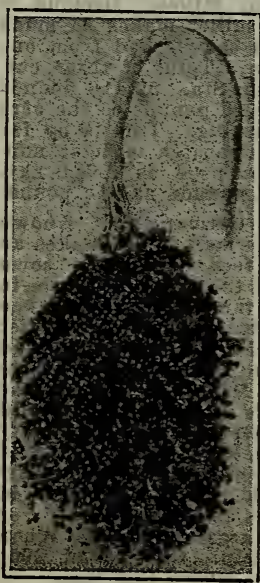

Goose Neck Sorghum. all sorghum syrup, and that the syrup keeps longer in a barrel or jug than other: sorghum without jellying. Heads bend over like a goose's neck, and are black, 5 to 9 inches long and 3 to 5 inches wide. Great demand and always scarce. Prolific in the finest syrup. One pound 30c; peck $\$ 2.25$; bushel $\$ 7.50$

SUGAR DRIP SORGHUMAlso called "Georgia Cane.' Falsely called "Texas Seeded Ribbon Cane.", Practically the same as Gooseneck, except it has straight head. Stalk at base 1 to 2 inches in diameter. One acre makes 200 or more gallons of syrup of good quality. Yields in forage three times amount Amber does. Seeds are larger than Orange, flatter, very much lighter in color; hull is maroon and shells clean. A new and separate and distinct sorghum. One of the best varieties for making syrup. An immense maker of forage; one seed pro. duces 7 to 8 stools and stalks. Largely planted in 4 -foot rows, 1 foot apart. Grows 12 to 15 feet high. Many growers think that it makes the sweetest and finest flavored of all syrups made of Sorghums. Seed often sold at fancy prices. On account of its especial sweetness, cattle are tremely fond of it. Much liked. A heavy seeder. In the Southwest it is called "Georgia Cane." The demand has been much more than the supply. One pound $20 \mathrm{c}$; peck $\$ 1.35$; bushel $\$ 4.50$

HONEY SORGHUM-Known in Tennessee as Japanese Seeded Ribbon Cane, and sold under this name by a number of seed houses. Mr. C. V. Piper, of the U. S. Dpt. Ag., says: "Was distributed by the Dept. for a number of years, and is the sweetest of all Sorghums." This new Sorghum makes an unusually large stalk, sometimes as large in diameter as Ribbon Cane and much taller. Prolific in juice, and runs higher in saccharine than any other Sorghum, being one of the heaviest yielders of molasses known. The product is thick and bright and much same flavor as our Sugar Cane. Thi syrup brings always a good price. New, and not much known; but much known; bu never yet has seed to supply one-fourth the demand. Seed head is a sprangled top one. S e ed husk is bright red. Is considered to be one of the most valuable Sorghums e $\nabla$ e known for syrup purposes, and as a forage crop. Price: One pound $20 \mathrm{c}$; peck $\$ 1.35$; bushel $\$ 4.50$.

\section{THE KAFFIRS} -Kaffir, Mr i 1 and Feterita and Shallu (called the grain Sorghums) for cattle feed and human feed, are in dry times a more certain

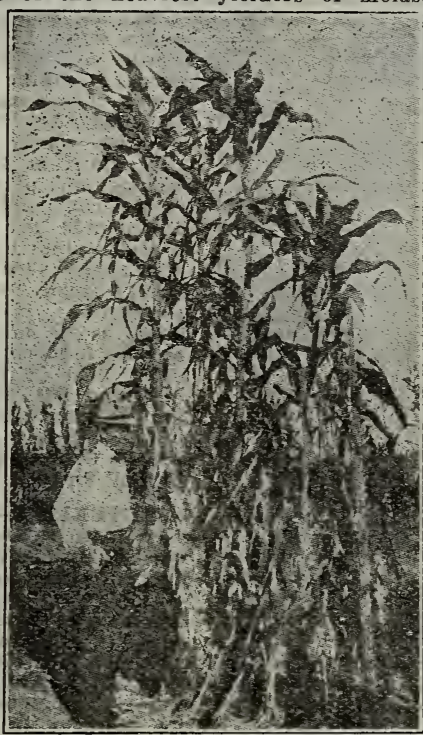

Honey Sorghum. crop for grain than corn. Easily make from 25 to 40 bushels per acre, 70 pounds of heads equal to 1 bushel corn. Cut stalk, shock, then cut off the heads and store in a dry place, and feed same on plank floor; and also feed the remaining roughage. Kaffir and Milo heads are sold loose in car lots, in a large way for feeding purposes in the West. Kaffirs are soft stalks (not hard like Sorghums). can be cut down and shocked up quickly. The Kaffir crops are inereasing rapidly. In the drier regions are wholly supplanting corn and are used for all the corn purposes.

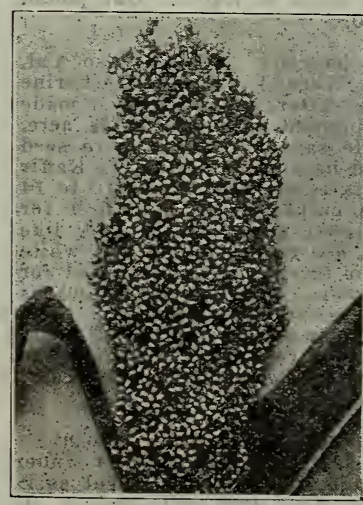

Head Kaffir Corn
KAFFIR CORN - $(50$ lbs. to bushel.) Miss. yield 30 bushels of seed on land making only 12 to 15 bushels corn. feeding 15 alue of Plant as late as July 20 -plenty of time to ma ture seed.' The principal crop in Oklahoma. Used as a part in all prepared chicken feeds. Sow with cow peas broadcast, at the rate of a peck of Kaffir corn to a bushel of cow peas per acre. Both can be cut together, making an enormous yielding crop of most nutritious feed. For a crop of forage by itself, sow broadcast at rate of from 1 to $11 / 2$ bushels per acre, or drill two pecks per acregood for three or four cuttings - 21,344 pounds of green per acre. For seed, plants should be from 4 to 6 inches apart. The ground grains make fine muffins, waf fles, etc.-700,000,000 people eat it. For mixed hay, one peck with $1 \frac{1 / 2}{2}$ bushels of cow peas; better than Sorghum, since Kaffir has a soft stalk and cures more easily. Get Bulletin 31, Agricultural College, Stillwater, Okla.

RED KAFFIR-This variety has red seed. Yields well on poor land and ripens earlier than the white and probably 
a little more hardy. Stalk is more tender and juicy. Heads are long and slender. Grows 5 to 6 feet, One pound 15c; peck $\$ 1.00$; bushel $\$ 3.25$.

WHITE KAFFIR-A straight, upright growth, with stalky stem and wide leaves. Yield in seed per acre, 30
to 40 bushels. Valuable for stock and poultry. A most to 40 bushels. Valuable for stock and poultry. A most attain unusual thickness, and put out enormous leaves, dense foliage, shades the ground, and absorbs the moisture. The stalks do not harden like other varieties of sorghum, but stap ripe. Fodder is relished by stock. Each stalk carries a large seed head. The ished by stock. Each stalk carries a large seed head. The joints look like sugar cane joints and from these joints
grow oftentimes suckers. Makes one or two quarts of grain per stalk. Price $1 \mathrm{lb}$. 15c; peck $\$ 1.00$; bushel $\$ 3.25$.

MILO MAIZE, or BRANCHING DHOURA-(50 pounds bushel.) A variety of Sorghum, non-saccharine, growing

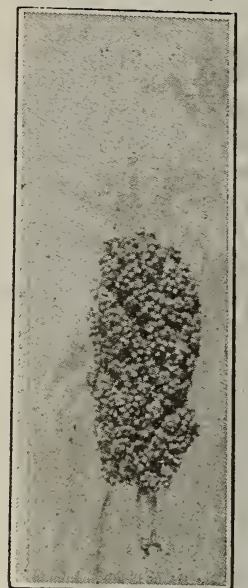

Head Milo Maize. stalks 8 to 10 feet high. Grows similar to Kqffir corn. Three weeks similar to Kqfirir corn. Three weeks earlier, making more grains per stalk. Texas matures Milo in July. its crop where corn would wholly fail. Plant in 3 -foot rows, leaving one or two plants every 6 inches in the row, and cultivate as corn; 12 pounds per acre, or drill 40 pounds; stool heavily- 5 to 6 stools from each seed; cut green many times; good for the silo. Very productive; makes sometimes as much as 40 bushels seed plus first cutting fodder. If hogs are turned on a field in Indian corn, Kaffir corn and Milo they will devour the entire Milo before touching either of the others. Seed larger than Kaffir One pound $15 \mathrm{c}$; peck $\$ 1.10$; bushel $\$ 3.40$.

FETERITA - (Sudan Durra), New. Also called "'Schriber corn." Resembles Kaffir and Milo, but is larger, softer grains and more digestible and makes sweeter flour. Popular in Texas and Okla, Same feeding yalue as corn. The earliest of the grain sorghums. White grains. Use as Kaffir. Joints look like sugar cane joints and from these joints grow suckers, each making a head; one or two quarts of grain per stalk. Feterita matures in quick time, being ready for the silo in 60 days, and thoroughly matures in 90 days. As a drought-resister, it surpasses Milo and Kaffir. Usually 7 to 8 feet high. A splendid hog and cattle feed; cut and shock, then cut off heads and store; feed heads on floor to horses and hogs, and the remaining roughage to floor to horses and hogs, and the remaining roughage to crop than an equivalent acreage in corn. Poor corn lands or droughty corn lands should go into Feterita for horse feed. 70 pounds heads make one bushel grain shelled. At Augusta stood 13 weeks' drought, made four cuttings for dried hay, and three weeks earlier than Kaffir. Stools 5 to 7 stalks per grain. Can be cut ripened and piled up for feed-head and stalks. Plant same as Kaffir. One pound $15 \mathrm{c}$; peck $\$ 1.20$; bushel $\$ 4.00$.

SHALLU-(50 pounds to bushel.) (Called also Cal. Rice, Cal. Wheat, Egyptian Wheat.) A non-saccharine Sorghum of widest use in India. Our Augusta grower made this year 30 bushels of seed planted very late on $3 / 4$ acre, and from 5 pints of seed. He says: "Makes more seed than any cane or sorghum, and nearly double that of Kaffir corn. Stools heavily, 4 to 6 stalks per hill, grows 10 to 14 feet high; planted early, two crops can be had, first for green cutting and second as seed crop. Heads look like large broom corn heads; seed are round, plump and white like Kaffir corn. Excellent for forage; seed unexcelled for chicken feed and good for cattle; excellent if ground as meal for the human." A grower in Alabama says: "We grow two crops in Alabama, and make as high as 70 bush. els to the acre." Plant in rows 3 feet apart, 10 pounds to the acre, or broadcast 25 pounds. Pound $20 \mathrm{c}$; peck $\$ 1.50$; bushel $\$ 5.00$.

TEOSINTE-(Euchlaena Luxuriana.) Stalk resembles Indian corn; stools heavily; sow in April, May or June. Cut when two or three feet high, and continue to cut as it grows out, all hrough summer. One acre will produce 30 tons green food in the season, and take-care of 10 head of cattle Miss. Exp. Sta. reports 22 tons per forage product. One seed makes 30 to 50 stalks or stools. On rich land grows 15 feet high, and produces larger amount of forage than any known plant. Have seen 225 pounds of forage from one seed; 10 per cent saccharine. Seeds only in extreme South. Plant 2 pounds to acre the last of. March, drills 4 feet apart, seeds 1 foot in the drill; cultivate as corn. Ripens last of November. It takes
85 degrees heat to germinate Teosinte; needs a long, hot season, rich soil, abundant moisture. Fine for silo. Price: One ounce, $10 \mathrm{c} ; 4$ ounces $25 \mathrm{c}$; pound $75 \mathrm{c} ; 5$ to 10 pounds at $65 \mathrm{c}$ per pound.

BROWN TOP MILLET-(Panicum fasciculatum.) (German Hay Grass; Kea Grass.) See Cut. New, only listed by us. In use here (an East Indian Grass) five years. Undoubtedly better than Sudan or Millets for grazing, green cutting or cured hay. Plant in April through July, well harrowed $r$ ic $h$ land, 3 to 4 lbs. per acre, 30 -in, drill, 18 to 24 -in rows, cultivate with swe or eight lbs. broadcast. An annual. Hay crop about 3 to. 5 tons per acre; cuttings in July, August and September. Stools heavily, averages 25 to 30 stems from 1 seed, and each stem makes a millet s e e d $h$ e a d resembling German Millet, but the se ed s them-

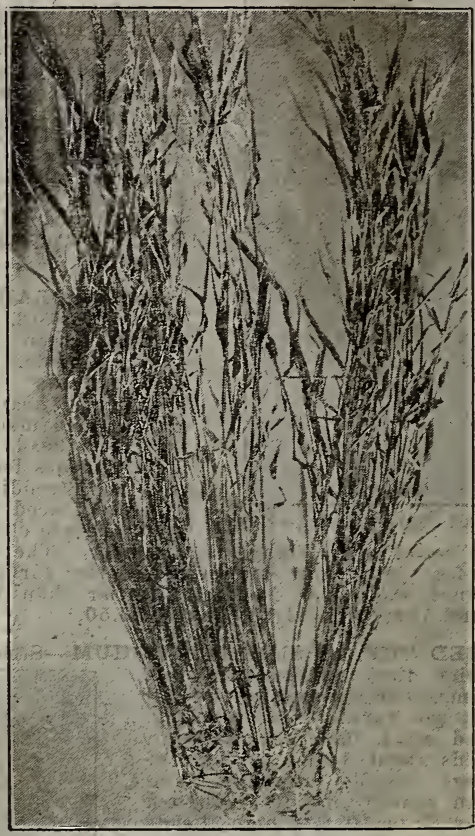

Brown Top Millet. larer much resembling Cat-tail Millet. Cut shows the product from one seed. Makes about 2,000 lbs, seed per acre; thresh like oats. A Ga, stockman says: "The best grazing grass I ever saw for hogs, mules and cows. They keep fat on it. Can graze in 5 weeks; in 6 weeks over laps rows; chickens feed on it green, or the ripe seed. Makes splendid, delicious hay, wide blades, tender stems.' A S. C. grower says: "Got 10 one-horse loads from $3 / 4$ acre, and my cattle ate the dried hay in preference to oats and corn cured in dough. Green till frost. About 3 feet high, 3 or 4 green cuttings per season if April planted. A wonderful addition to the grasses and millets. One grower says Brown Top Millet is worth to Southern Agriculture as much as is the Velvet Bean. Caution! This grass under a drought will go dwarf and head out; cut it back before heading, and a good season will bring it to a tall growth.

Price: One $1 \mathrm{lb}$. 90c; 5 to $10 \mathrm{lbs}$. at $75 \mathrm{c}$ per $\mathrm{lb}$.

GEORGIA PEARL, or GEORGIA CAT-TAIL MILLET(Pennisetum "Specatum)-Known also as Pencillaria, also Horse Millet, and Maud's Wonder Forage Plant. We are largest Southern handlers of Cat-Tail Millet. Demand is aways more than supply. No other millet makes so much green forage as this. Seven cuttings can be had from one planting about Augusta in one season. Total of three cuttings green forage per acre at Ga. Exp. Sta. 52,416 pounds - equals 10 tons cured fodder. Drill 10 pounds to the acr in 3. feet or closer rows. Plant in spring. This is by far the most popular of all the green quick-eaten millets; nonsaccharine, not sold by bushel. Not used as, dried hay. Pound $35 \mathrm{c} ; 5$ to 10 pounds $30 \mathrm{c} ; 50$ pounds at $25 \mathrm{c}$ pound.

GERMAN MILLET-(Chaetochia Germanica.) Known as Tennessee and Golden Wonder. German Millet makes an enormous yield of most nutritious feed. Must be sown thickly, about 1 bushel per acre, and the crop cut while in bloom, before the seed hardens in the head. Sow when weather gets warm in. May or any time during the summer until the end of July. Two crops have been seeded and grown during the summer on the same land; good hay com-
bination with cow peas. German Millet is one of the bination with cow peas. German Millet is one of the quickest maturing plants that we have as a hay crop. Could plant as late as the middle of August and make a pretty hay It is not considered safe to feed millet continuously to horses and mules for a long period, but if they are fed once a day on millet hay, no harm is likely to come. For hogging plant March and April and graze oin June. When cut the plant does not grow out again. One pound 20c: peck $\$ 1.35$; bushel $\$ 4.25$

JAPANESE MILLET - (Panicum Crusgalli) - (32 1 . $1 \mathrm{bs}$. bus.) In La. constitutes 50 to 75 per cent of food of ducks. 
Grower says: "In five weeks from seed, was 4 feet high, and heading well." "Rank grower, bushy head. Matures as high as Canada. Superior to German millet; stalks much thicker than German. Also called Billion-Dollar Grass, Barnyard Millet, Goose Grass, Louisiana Wild Rice, Blue Duck Food. For hay, grazing or green cutting; cut 5 or 6 times, or can be broadcast and cut for hay 3 or 4 times. Miss. Agl. Col. says: "Produces per acre 36,000 lbs. of fodder or makes 12,000 lbs. of cured hay, or 67 bushels of seed; hay surpasses a good corn fodder. Annual. Sow from April to August 1st, 32 lbs. per acre. Makes crop in 6 to 8 weeks. Can be cut for hay several times and then fall grazed. Stools heavily. Cut for hay just before seed heads form. Seed head large, $61 / 2$ inches long. In rich lands grows $3 \frac{1 / 2}{\text { to }} 4$ feet high. Resembles rice in growing; heavy bladed; grows in upland and is at home perfectly in wet black land; under water sometimes two weeks, a fine producer on waste wet lands. Japanese Millet in 32 days, as planted at Augusta, showed full grown seed heads and plant $5 \frac{1}{2}$ feet high with 8 or 10 stools per plant. One 1b. 20c; 25 to $50 \mathrm{lbs}$. at $12 \mathrm{c} ; 100 \mathrm{lbs}$. at $10 \mathrm{c} 1 \mathrm{~b}$.

POP CORN FOR FORAGE-Makes quick spring forage. Earlier than other corns. Full grown in June and stooling heavily, it makes a world of forage which, when cut and fed, the corn in the milk and green forage makes a perfect ration and a world of it. Can be sowed up to July 4th, in 3 or 4 -ootf rows, several grains every 6 inches, 1 peck to $1 / 2$ bushel per acre. $1 \mathrm{lb}$. $25 \mathrm{c} ; 5$ to $10 \mathrm{lbs}$. $20 \mathrm{c} ; 25$ to $50 \mathrm{lbs}$. at $18 \mathrm{c} ; 100 \mathrm{lbs}$. at $16 \mathrm{c}$ per $1 \mathrm{~b}$.

JAPANESE SUGAR CANE-We sell December 1st to April 1st, f. o. b. Florida. Highly prized and in largest use in Florida and South Georgia. Will probably produce

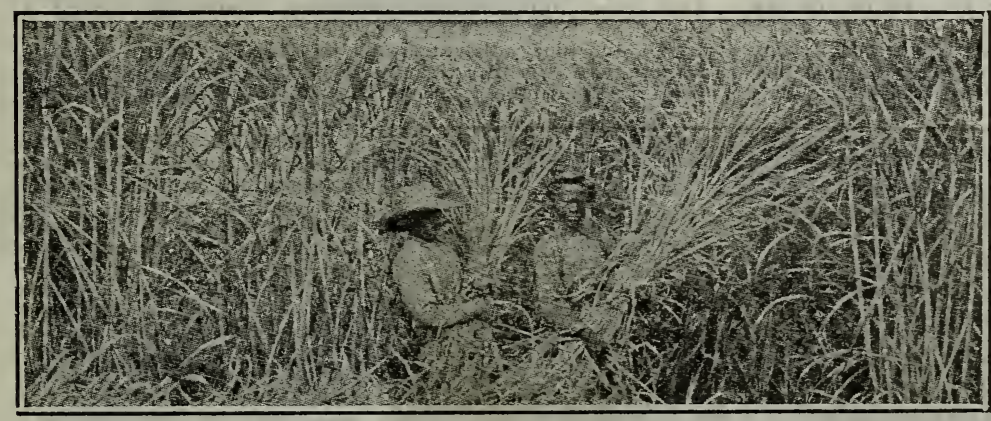

Japanese Sugar Cane.

more forage per acre than anything known. Also affords fine support for Velvet Beans when planted together; can be eaten at same time through the winter. It is not a Sorghum. Is strictly a sugar cane. Each joint of stalk has an eye. Each eye is a perennial, and when planted produces from 10 to 12 stools, and a maximum of 20 for produces from 10 to 12 stools, and a momething like 3 each eye. Has immense root ssytem, something like feet. Very prolific, making from 10 to 12 tons per acre, and 15 gallons of syrup per ton. Will do better farther
north than any variety of sugar cane. Once planted, if properly cared for, will last 3 to 8 years, sprouting from the stubble each spring. Its syrup is of excellent quality; can hardly be told from Ribbon Cane, and is preferred by some. The sugar cane grinders for sugar purposes, pay only 10 per cent less for Japanese canes than for Ribbon Canes. Cut the stalks before frost, stand them up against the hout the stalks before frost, stand them up against the house, spread pinestra-w over them to prevent frost, and feed cattle with same in February. One acre averages 2,-
150 hills averaging 18 stalks to the hill; the stalks running 4 to 6 feet high, making thus 154,800 feet of seed cane per acre. We ship full length stalks about 5 feet long simply tied in bundles of about 250 stalks for express or freight. Requires about 1,000 stalks per acre. Cut up stalks into lengths 12 to $14 \mathrm{ins}$. long and plant $4 \mathrm{ft}$. apart in 6-ft. rows. Price, cash with order, f. $0, \mathrm{~b}$. Florida. 1,000 stalks $1 c$ each; 500 stalks $11 / 2 \mathrm{c}$ each; less than 500 stalks 2c per stalk.

\section{PEANUTS}

THE PEANUT AND ITS CULTURE AND USES.(Arachis Hypogea)-An annual legume. Also called Pinders, Goobers and Ground Peas. One of the big cash crops in this country. Tremendous amounts are being grown. Get farmers' bulletin No. 751, "Peanut Oil,", Als "'Peanuts for Profit," from J. F. Jackson (C. R. R.), Savannah, Georgia.

Best soil, light sandy loam. Level culture best, prepare ground with disc harrow. Plant running peanuts in 36 -in. rows and 12 ins. between; bunch peanuts 30 -in. rows and 6 to 8 ins. apart in the row; plant $11 / 2$ ins. deep. To gather bunch peanuts, run a plow in the fall close to the pearoot knot. profitable a

cotton at 15 hard hog flesh.

nuts, take pitchfork and lift up peanuts with the vines; in 3 or 4 hours, stack peanuts with the vines, around a ridge ridge poles to be 8 feet high, with 2 cross-pieces above (See Cut.) In winter tound. hand or Lilliston machine, and feed the hay. For hog pur-

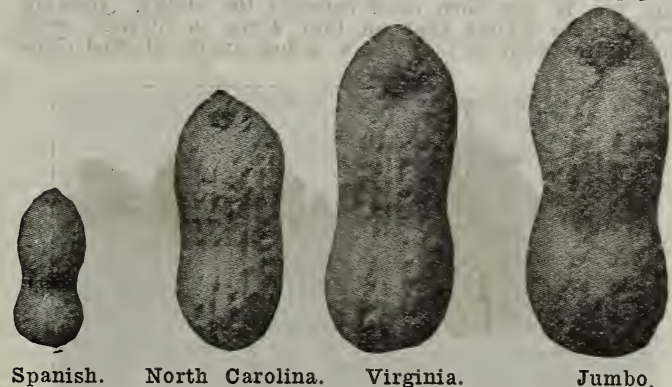

poses, plant 2 bushels per acre, April 15 th to July 15 th. Graze from August 15th to January 1st. To make hay, har vest before frost. One acre peanuts makes 1,000 pounds pork. Peanuts, like velvet beans, are not affected by wilt

USES-Parching, confections, butter, salad and cooking il, cattle and hog feeding, cake, ground hulls for feeding, and "hogging"' in field. A fine grade of peanut hay can be semowing the vines. Only a secondgrade hay and somewhat dirty and coarse can be secured from vines from which peanuts were threshed. WHITE SPANISH - (Arachis Hypogea - -30 lbs. to the bushel. acre; break pod in two parts, and plant at once. an plant at once. Lime sour land land, 500 to 800 lbs guano, 12 per cent. Phos. Acid and 2 per cent ammonia. Plant in $2 \frac{1}{2}$-foot rows and 6 or 8 inches in the rownever plant further apart. From 40 to 90 bushels should be made per acre, and the residue of hay should total the cost of the peanut crop being usually one ton peanut cellent hay worth about $\$ 22$. most valuable peanut of all the peanuts for oil-contains 5 to 10 per cent more oil than other types and the earliest. In tremendous use as ground up by oil mills for oil and cake-one ton of peanuts in pods yielding 80 gallons of delicious sweet oil and yielding also 750 pounds of the best feeding cake. Supplants cotton on sandy lands as a Southern money crop. As easily sold as cotton, and as

cents. Oil mills

pay $30 \mathrm{c}$ per bu. more than seed, and are using product using product acres or 70 , 000,000 b today 0 is. two years ago they w e $r$ grinding none. The oil and cake are superior to that f $r$ o cotton seed. $r$ Peanut meal $\mathrm{m}$ a $\mathrm{k}$ e One acre in pea nuts is worth 1 acre in cotton, pro d u c i n $\mathrm{g} 3 / 4$ bale per acre. One man in $\mathrm{S}$. C. made 100 bus. per acre on 300 acres. Hay equals alfalfa in $\nabla$ alue.

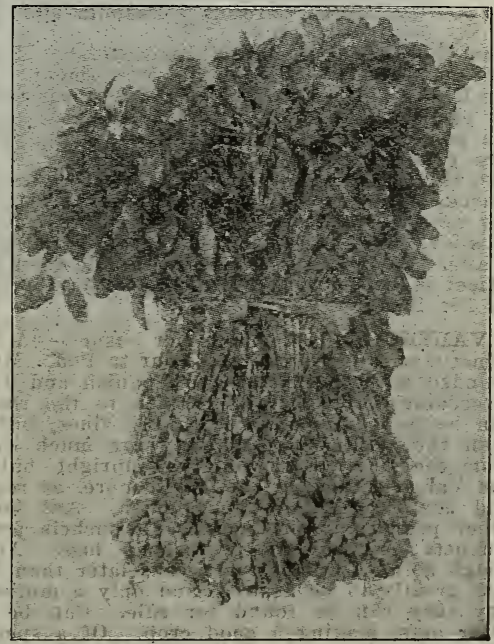

White Spanish Peanuts

Mature in 110 days. Small pods, strong growing up right stems, abundant and heary foliage, pods cluster a 
base of plant and attach to the roots. Magnificent hog crop. Plant April to July 15th or following after oats. Hogs can be turned in on patch or the vine can be fed all winter from the storage barn after peas have been picked. Plant, too, in late corn rows between the stalks. Georgia correspondent writes that on four acres in 30 -inch rows
planting one seed to the hill, 8 inches apart, planted June

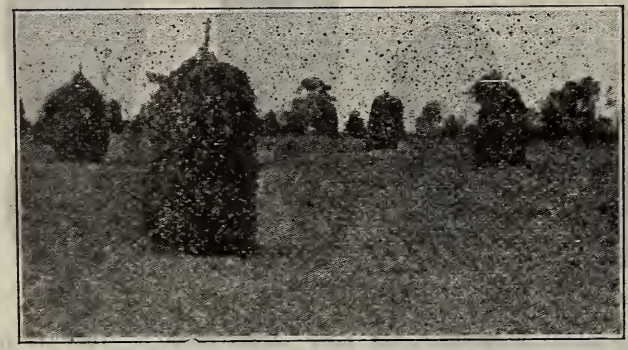

Field Spanish Peanuts Stacked.

10 th, dug October $23 \mathrm{~d}$, kept in shock until November 10 th, and then hand-picked at a cost of $10 \mathrm{c}$ per bushel, he made 230 bushels of peanuts on the four acres plus $\$ 60.00$ worth of pure hay. About 460 unshelled peanuts weigh a pound. Price: $5 \mathrm{lbs}$. at $18 \mathrm{c} ; 10$ to $25 \mathrm{lbs}$. at $15 \mathrm{c} ; 50$ to $100 \mathrm{lbs}$. at $12 \mathrm{c}$ per $1 \mathrm{~b}$.

LITTLE RED SPANISH-( 30 pounds to bushel)-Originated a few years ago in Georgia. They are a bunch peanut and pods adhere to the roots. The bunch is larger

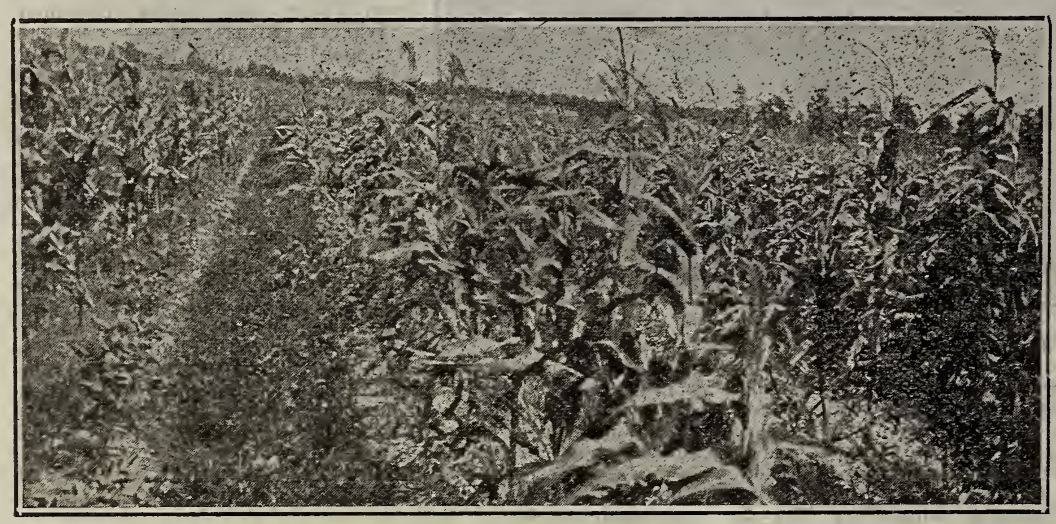

"North Carolina" Peanuts and Corn Growing in South Georgia. at $20 \mathrm{c} ; 100 \mathrm{ibs}$. at $18 \mathrm{c}$. lbs. at $18 \mathrm{c} ; 100 \mathrm{lbs}$. at $16 \mathrm{c}$. pod, and all sound, and eliminate pods carrying only 1 or 2 . Hand-picked graded peanuts of 3 and 4 to the pod always fetch a premium. Pick when they are ripe; they sprout in the erround sooner than other peanuts. The highest priced of all peanuts. Price: 5 to $10 \mathrm{lbs}$. at $25 \mathrm{c} ; 25$ to $50 \mathrm{lbs}$.

TENNESSEE RED-(24 pounds per bushel)-Run “' 3 's and 4's." Very hard shell, and hard to crack same with fingers Universal for red land peanut. A bunch pea, bright red, attach to the roots, contain from 3 to 4 peas to the pod; shell thick and tough; well adapted to hog. raising, as peas will stay in the ground all winter and come up in the spring. Better adapted for hog than human use. Bunch-tops, and peanuts can all be pulled up at one time with the hand, and afterwards the hay can be baled and the peanuts taken from the roots. Easily handled, shelled we earlier than Virginias. Smaller and harder pods weigh about $1 \mathrm{lb}$. Price: 5 to $10 \mathrm{lbs}$. at $20 \mathrm{c} ; 25$ to 50

NORTH CAROLINA, or IITTLE WILMINGTON-(24 pounds to bushel)-Known as African, Wilmington and Florida Peanut. A running peanut, smaller than the Virginia Running or Bunch, but somewhat larger than the White Spanish. The great hog peanut. In South Georgia and Florida are used in tremendous amounts for hog purposes, as the peanuts do not rot as lying in the soil through the winter. Hogs in the field do all the gathering. Peanuts fill the whole pod and contain no pops. Sometimes vines cut for hay, and nuts then hogged. Yields 60 to 90 bushels per acre. A small-podded variety, with very heavy dark-green foliage; stems creeping, sometimes having-a spread of 3 or 4 feet; pods scattered along procumbent stems and not adhering well in digging; small, a little larger than the Spanish variety, usually containing two peas. Price: 5 to $10 \mathrm{lbs}$. at $18 \mathrm{c} ; 25$ to $50 \mathrm{lbs}$. at $15 \mathrm{c} ; 100$ lbs. at $12 \mathrm{c} \mathrm{lb}$.

VIRGINIA RUNNER-(22 pounds to bushel) -120 days in maturing; resembles North Carolina in growth, except pods are larger, 279 pods weigh a pound. A large-podded variety with heavy foliage; stems creeping; pods scattered along procumbent stems and not adhering well in digging; pods and peas similar to those of the Virginia Bunch peanut. This variety is harder to cure than the bunch types, because the pods are scattered along the stems and can not be as well protected from the weather as the varieties with nuts clustered near the base of the plant. Is usual Norfolk parching peanut. Sold for parching. Price 5 to $10 \mathrm{lbs}$. at $15 \mathrm{c} ; 25$ to 50 lbs. at $13 \mathrm{c} ; 100 \mathrm{lbs}$. at $12 \frac{1 / 2}{2}$.

VIRGINIA BUNCH - (22 lbs. to bushel)-Plant as late as first of June in Virginia, and mature by frost. Exceedingly productive Stems upright; pods attach to the roots of plant; usually 2 to the pod. Peas light brown pods, bright and clean, and adhere well to the plant in digging. Pods and peanuts quite large. A large-podded variety with rather light foliage; stems upright; pods clustered about the base of the plant. Have a lower oil content and a smaller proportion of meats to shell than the Spanish; should not be grown for oil purposes. 280 pods to the
pound. Price: 5 to $10 \mathrm{lbs}$. at $15 \mathrm{c} ; 25$ to $50 \mathrm{lbs}$. at 13c; $100 \mathrm{lbs}$. at $121 / 2 \mathrm{c}$

BUNCH JUMBO-(22 pounds to bushel)-Grows upright, easily cultivated; maturing in 90 to 100 days; requires better land to make; does uot speck in stacks. Plant $2 \frac{1}{2}$ feet row, 12 inches in drill; usually ridge culture; good on red land. Our largest peanut. Price: 5 to $10 \mathrm{lbs}$. good on red land. Our largest peanut. Price: 5

RUNNING JUMBO-Same price as Bunch Jumbo.

HOG GOOBER-(Woandzeia Subterranen) - 25 pounds to bushel)-Used only for hogs. Come in pods like peanuts, except that the pods are single; are very large, as large as the end of your thumb; pods are thick on vines; peas inside are single. The taste of the pea is somewhat betwee nthat of a peanut and field pea. Will not sprout in the ground; will remain all winter in the ground for hogs. Nuts partly detach from vine in harvesting. Yield much greater than that of chufas Plant about 30 pounds per greater than that of chufas. Soak shells or shell the pods before planting. Many acre. Soak shells or shell the pods before planting. Many growers say yield per acre is double that of other peanuts.
Extra good hog feed. Planted in 3 -foot rows 16 inches to the row, and plowed only twice, these goobers here grew solid in row. Vines trail on the ground. Make hard and not soft hog flesh; and negroes do not eat up the crop. After pulling vines, dry for several days. Gather in October 
before frost. Each pod contains only one pea. Never make pops and keep well in ground. Our grower gathered on 8 acres 240 bushels and fed 25 hogs 3 months on bal ance in field. Price: $1 \mathrm{lb} .30 \mathrm{c} ; 10$ to $25 \mathrm{lbs}$. at $22 \mathrm{c} ; 50$ to $100 \mathrm{lbs}$. at $18 \mathrm{c}$ per $\mathrm{lb}$.

GEORGIA CHUFAS-(Cyperus Esculentus)-(44 pounds to bushel-Hognut; Ground Almond. (See two cuts.) Annual. Georgia-grown seed. Demand always consumes supply b e f o r e April 1st. One of our growers recently $\mathrm{m}$ a d e 1,000 bus. on 100 acres. An. other made 157 bus. on one acre planted July 4. These attach to the roots. The vines can be pulled up for saving seed and seven-eights will be found attached to the $r$ o o t $s$. The vines, after being pulled up, should be allowed to thoroughed to thoroughly dry for sev-
eral days. For feeding value an acre of Chufas

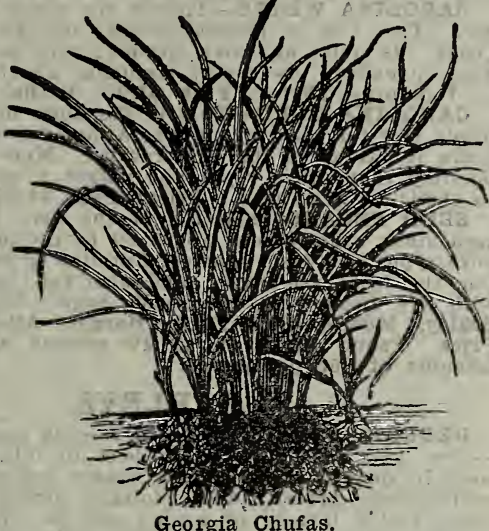

Georgia Chufas.

equals 40 bushels of corn. There is no better hog crop known. For hog purposes plant from April to about May. 10 th, turn in hogs September 15 th to tJanuary 15 th. Mature about October and will lie in ground without rotting until a Grow best in drill, rows $21 / 2$ feet apart. Do until eaten. Grow best in dril, rows and hoeings. If you get a poor stand, pull out shoots and transplant them. Chufas follow oats splendidly. Plant, June or July. Chufas are frequently matured and harvested within 90 days

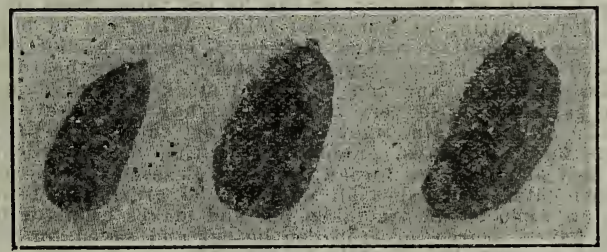

Chufas-Natural Size.

after planting. Plant 1 peck to acre, 10 inches in drill. Reproduce if left in ground. Hogs sometimes fed by pulling up vines and nuts together. Best of all crops for winter ego-making. turn in chickens in the field. Price: wuart $40 \mathrm{c}$; peck $\$ 2.50 ;$ bushel $\$ 8.00$.

JERUSALEM ARTICHOKE-(Helianthus Tuberosus)Georgia grown. Cut artichoke into four pieces, each one with two or three eyes. Plant at the same time as Irish potatoes 18 inches in drill and with rows 4 to 5 feet apart; pot't work after plants shade ground. Fine hog crop; produce in rich land 300 bushels per acre. Even in 5 -foot
rows run from row to row and make tubers-the underground being a network of artichokes. Will stay in ground

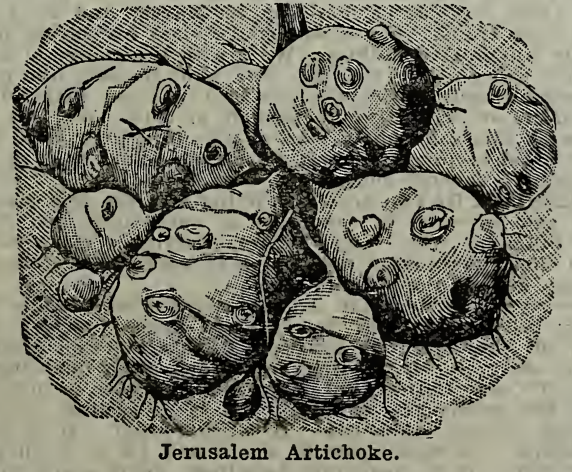

for gathering at any time all winter, and not freeze. Better and sweeter as a human food than anish preez. Better and mash, or fry. Productive on poor soils; cultivation and mash, or fry. Productive on poor soils; cultivation
is inexpensive. Can bed like sweet potatoes, and then transplant. Turn in hogs at any time. For hog purposes, plant 3 to 5 bushels to the acre from February 1 st to March 1st. Graze from November 1st to January 1st. If not eaten too close; crop will come up next spring without second planting. We sell by measured bushel in January and February-about 50 pounds. One peck $90 \mathrm{c}$; bu. $\$ 2.75$.

CASSAVA-A productive root crop-10 to 15 tons per acre. Roots remain in ground all year. Best for feeding November to April-dig and cut up roots and feed. Plant last year's canes or stalks in February or March, in light, sandy, dry soil 62 per cent starch and 19 per cent sugar. Juicy roots. Fine for horses, cows and hogs. An excellent table pudding food (tapioca). We only sell f. o. b. Florida. To save stalks for planting, cut bofore frost and bank same as Ribbon Cane. Highly edible. Roast like Irish potatoes. For pudding, grate and add one cup of sweet milk, two eggs, sugar and flour, and some milk and cream. We ship in 1 foot (12-inch) lengths; grower will cat to 4 to 6-inch lengths, with several eyes and plant in checks 4 feet by 4 feet-about 20004 -inch checks to the acre. Prices: Only f. o. b. Florida, $7001 \mathrm{ft}$. canes (for 1 acre) $\$ 9.00 ; 100$ for $\$ 1.75$ - for express.

RUSSIAN SUNFLOWER-Sow in spring, 5 pounds to the acre. Great improvement over the small sunflower. Some are 18 inches in diameter. In Russia are used for oil. Known here as the best of all poultry foods. 40 to 50 bushels grown per acre. In cities it is the parrots' feed. Not only a valuable seed to plant on farm, but every inch of waste space around the fences and yard and field ditches shold be planted in this seed; it will not only improve and beautify the place, but will produce large amounts of the beautify the place, but will produce large amounts of the
most valuable feed. Numbers of Georgia growers grow this now as a seed money crop. Fine bird attracter and feeder on the farm or game preserve. Plant in 3-foot rows and 8 to 12 inches in row. Cut off heads and shell by rubbing over a big rough stone or corrugated iron. Green stalks and seed as cut make a fine silo Price: Pound 20c; 5 pounds at $18 \mathrm{c} ; 25$ to 50 pounds at $15 \mathrm{c}$ per pound.

DWARF ESSEX RAPE-(Brassica Napius)-The universally grown forage crop in England, Germany and Canada for pasturing lambs, sheep and hogs, and also for

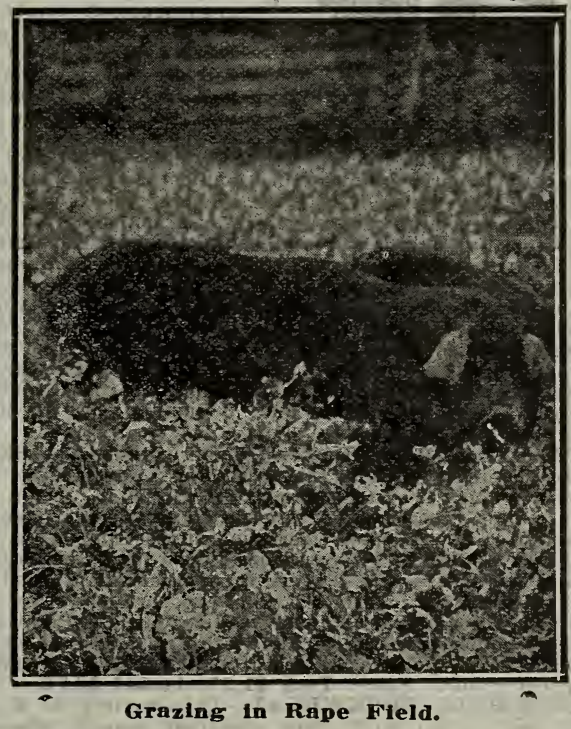

cows. Drill 10 pounds per acre, in 3 feet drills in spring rall lands, or drill in rich uplands. Many hog growers use Bermuda grass in summer and use for a winter grazing proposition, solely rape. Fla. Exp. Sta. says: "We hav raised as high as 22 toris to the acre in a single year. Fif teen tons of green matter can be expected almost every year. Especially adapted to feeding to hogs, sheep and cattle. Comes in during the latter part of November and contil the warm spring weather occurs." continues green makes in two months an enormous amount of green feed, makes in two months an enormous amount of green feed, two or three feet high and branching. Deserving of large use for green cattle feed in winter when rye is almost the only thing to be had; does not make milk "taste." Can be grazed or cut three or four times. Never cold-killed; fine for green winter chicken feed. The plants may be cu 4 inches above the ground, which enables them to throw South; thrives best in cold weather; furnishes an excellent 
winter pasture. At Augusta can be sown and cut almost every month in the year except in summer months. Splendid as a human food-cooked like spinach and a tender plant
can be cut over and over again. It makes one of the very can be cut over and over again. It makes one of the very
finest of salad greens and is produced in enormous amounts, making it the cheapest "greens that the grower can grow.
Price: $1 \mathrm{lb}$. $20 \mathrm{c} ; 5$ to 10 lbs. at 18c; 25 to $50 \mathrm{lbs}$. at 16c; 100 lbs. at $14 \mathrm{c}$ per $\mathrm{lb}$.

BEGGAR WEED-(Desmodium Tortuosum)-The Clover of Florida. Legume. Grows 4 to 8 feet high. Sow.12 to 15 pounds per acre; barely cover; drill or broadcast seed, or sow in June grains on top of ground in corn rows at last cultivation; comes up in June and matures in 80 days; can cut several times or pasture late summer and fall; cut is indigenous to upper and middle Florida. Comes up in

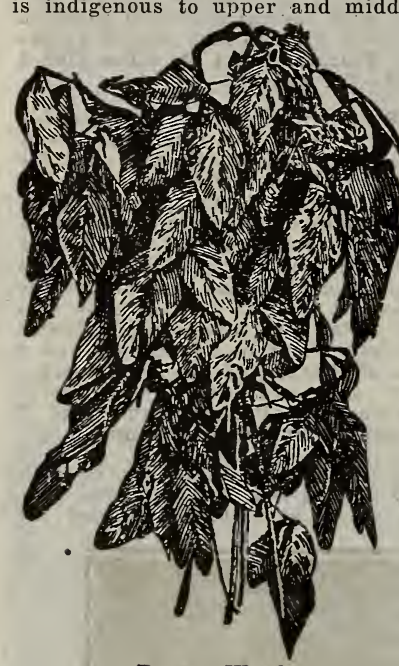

Beggar Weed cultivated fields about
first of June. In worn first of June. In worn of soil it has no superior. United States Senator F. M. Simmons, of "North satisfied it is the best of all leguminous forage and land improving crops for the lighter lands of the eastern part of the Fine for green cutting. For hay cut when 3 or 4 feet high. A wonderful cattle fattener. For hogging, broad cast 10 pounds per acre, graze when one foot high up Spreads rapidly; will take possession on land and come in as a voluntary crop exactly like crab grass. A single cultivation of the soil after Beggar Weed starts will kill it out so that it pest. Demonstration Fla. farm and planted June 6th, harvested 6,300 pounds August 6th. Wonderful for feeding; 21.7 per cent protein, 30.20 per cent carbohydrates, and 2.30 per cent fat. In Florida, an orange grove cover crop. Good for pasture, hay or green manure. Some plant after Fulghum Oats and make a crop in time to plant Feterita. Miss. Exp. Sta. reports 42.429 pounds again, making two cuttings as far north as North Carolina. Planted largely in game preserves. for attracting and feeding quail. Citrus trees do better on the humus and nitrogen from Beggar Weed than that from other legumes. The hay-two cuttings - is high in protein and cures easilyone day. Price: One p

JAPANESE BUCKWHEAT- $-(48$ lbs, to bushel)-Should e more generally sown in the South for poultry feed. Sow in early spring or late summer; matures in about two months. The Japanese is quite an improvement over the old varieties; the kernels are much larger and it is wel suited for the South. Grows on almost any soil, resists heat and drought. The blooms furnish excellent food for bees. Buckwheat, together with Bene, are the two best plants of all for attracting and feeding birds. Planted in Florida Demonstration Farm June 6th and gathered in $\mathrm{Au}$ gust made 2,637 pounds. A plant in large use for making Buckwheat Flour. Price: Peck $\$ 1.25$; bushel-\$3.75.

SILVER-HULL BUCKWHEAT-This variety is a well

known late variety and gives excellent results wherever planted in the South. A plant in large use for mak mine
Buckwheat Flour. Price: Peck $\$ 1.25 ;$ bushel $\$ 3.75$.

UPLAND RICE-(44 pounds to bushel)-The varieties

we list are the most popular, and the ones we recommend for planting throughout the South. For lowland culture get U. S. Farmers' Bulletin No. 417. The food of one-half 15 th, one bushel and roll, for uplands, in 20 -inch rows. For farmers who have lowlands that can be plowed, but are too wet for other purposes, the growing, either for home use or for selling to mills, of rice, can be profitably done. use or for selling to mills, of rice, can be profitably done.
The seed that we sell is free from wild rice. Threshed rice straw makes (baled) fine hay and in large use on South Carolina coast. Yields 25 to 75 bushels per acre, and one or two tons of dry straw for baling.

BLUE ROSE RICE-Originated in Louisiana. The largest Georgia Coast Rice grower declares it to be the best rice yet introduced. The stalk is sturdy, and of blue-green color, and retains its color after harvesting better than other straw, makes, therefore, finer forage. The grains are full and heavy, and the plants scatter less than any
known rice. The percentage of whole rice runs about 85 per cent or 90 per cent. Hull is same color as white rice, but the grain is shorter, more blunt, and of much greater thickness. It is the prettiest rice of the White Hull type on the market. A grower says: "It sticks to the head better than other rices and is the largest white-grained rice I have ever seen, and it pounds better than any other rice. Price: Peck $\$ 1.50$; bushel $\$ 5.00$

CAROLINA WHITE-This is the great Rice for upland use. This rice is planted largely on the South Atlantic Coast. Is quite an early species; very pearly and bright when pounded. Is early; maturing about the same time S Honduras. Price: Peck \$1.25; bushel \$4.50.

CAROIINA GOLD-This is the most popular and prof itable rice for planting on the Atlantic Coast. In average years it has given the best results. More largely planted possibly than other types and makes a good yield. 'Hard to shell; of firm head. Price: Peck $\$ 1.25$; bushel $\$ 4.50$. SEED PECANS - Selected of the very best type. Our seed stock usually runs about 60 to the pound. Our seed pure types and from fanciest Carolina grower. Diseasespure the leaf case-bearer, and also fall web worm, spray with Ars. Lead. See Insecticide page. Types are: Stuart, Schley, Mobile, Pan Yagil, Hermit, Atlantis, Frotscher. Price: Pound $\$ 1.25 ; 5$ to 10 pounds at $\$ 1.00$; larger amounts at $85 \mathrm{c}$ per pound.

\section{BARLEYS,}

GEORGIA BEARDED BARLEY-(48 pounds per bushel) - Sow $1 \frac{1 / 2}{2}$ bushels to acre; best in fall, though can be sown in spring; excellent fall, winter and spring pasturage; continuously grazed; dense foliage, strong and nutritious food; yields largely of grain; can be cut for grain two weeks earlier than wheat. For fall, winter and spring grazing, it stools out more and is, therefore, better than wheat or rye. See Fall Catalog. Price: Peck \$1.00; ushel $\$ 3.25$.

GEORGIA SPRING BEARDLESS BARLEY-Introduced into the South by us. We are large handlers. (48 pounds to bus.) Sow in August and cut in October, or sow for spring use February through March; ripens in June or before; makes fine fall grazing. Can be planted for fall grazing at the last laying by of cotton. Makes a big yield of seed, sown in February, or can be cut three times up to May 30 th, cutting at last waist high. When cut in bloom and before seeding makes fine hay; ripens earlier than bearded and is taller, larger and stiffer. Being beardless, is easily handled, and can be fed to stock without danger, same as oats; cattle very fond of the hay; heads are sixrowed; hulls remain tight after being cut; long heads: ripens 60 to 90 days. "February planting makes quickest and best of all spring forage; better and safer than springplanted oats. Furnishes all winter good grazing and then runs up when cattle are taken off, and makes crop for hay when hay is scarce, or crop can be cut and saved for seed purposes. Sow $11 / 2$ bushels to acre.

Good plan is to plant in fall, a combination of one bushel of beardless, 24 pounds of Vetch and one bushel of Rye. Cut Beardless in 60 to 75 days. Cut your Rye early next year and in early May your Vetch will be ready. Dairy men at Augusta use this plan largely. Peck $\$ 1.35$; bushel $\$ 4.50$

WINTER BEARDLESS BARLEY No. 50-New. See our fall catalog for this splendid never cold-killed winter barley that is strictly beardless and to be listed this win
the first time, Price: Peck $\$ 1.35 ;$ bushel $\$ 4.50$.

\section{OATS.}

SEED OATS-(32 pounds to bushel.) - Culture: Usually two bushels of oats are sown per acre broadcast. Drilling requires from one bushel to one and a half bushels per acre. Can be planted here up to March, and as a rule make good crops. The most popular oats for spring planting are Fulghum and Burt. We are in the center of a tremendous oat-growing section. For smut in oats, one pound of Formaldehyde (price 65c per pint), mixed with 50 gallons of water, will treat 50 bushels of oats. Wet the seed oats with this solution, spread on the hard ground or floor, throw a canvas over or sheet them, and allow them to stay covered for several hours.

FULGHUM OATS-Our Mr. Willet was the first man, 10 years ago, to write in the press as concerning and to explouth this unsurpas millions and millions of dollars.

Two weeks earlier than Appler; three weeks earlier than Texas; fully as early as Spring Oats. Ready for feed April 25 th; off the land by May 10th. This extreme earliness affords early Spring feeding and allows early planting for crops of Corn, Cotton, Sorghum, etc. Carries as much foliage, the grains are as large, and is as prolific in grain cold-killed. It withstands in the North 16 or 18 degrees below zero. It is absolutely beardless, drills easily and is a safe horse feed proposition. The best and most remarka safe horse feed proposition. The best and most remarkOats planted the middle of February made better oats than Applers that had been fall planted. Furthermore, they were cured and in the barn and the ground sowed to peas 
before the Applers were cut: Fulghum Oats planted even in in March, Augusta, 1918, made fair crops. This sall Catalog for full description. Price: One bushel $\$ 2.00 ; 5$ to 10 bushels at $\$ 1.85 ; 25$ bushels at $\$ 1.75$. Get prices on larger amounts.

GEORGIA APPLER OATS-(32 lbs. to bushel.)-One of the finest oats in the South. Rust-proof; hardier than Texas. Heavy, often 37 pounds to the bushel. Matures about ten days earlier than native rust-proof and week or ten days later than Burt. Exceedingly prolific; can be harrested about the last week in May. Georgia Experiment harvested about the last week in May. Georgia Experiment Station says about 10 to 15 per cent better in straw and oats than native rust-proof oats. One-third larger than Western rust-proof oats, and with far less immature oat and waste. Give far better yields and are less cold-killed cheaper, are not a good investment for Southern planting. For full particulars, see Willet's Fall Catalog.

Price: One bushel $\$ 1.75 ; 5$ bushels at $\$ 1.50 ; 10$ bushels at $\$ 1.40$ per bushel. Get prices in large amounts.

GEORGIA BANCROFT OATS-An improvement over Texas Rust-proof. Very little difference in these two oats, namely, the Appler and Bancroft. One party near $\mathrm{Au}$ gusta, with four acres last year, made 90 bushels to the acre. A Florida correspondent of ours, who made 4,000 or 5000 bushels of Bancroft reports average as being 50 bushels per acre. For full particulars see Willet's Fall Catalog. Price: One bushel $\$ 1.75 ; 5$ to 10 bushels at $\$ 1.50 ; 25$ bushels at $\$ 1.40$.

THE 100-BUSHEL OATS-An improved type of Southern oat, rust-proof, heavy grains, large straws, and extremely productive. We certainly can not, nor can anyon else, guarantee 100 bushels to the acre. For full particulars, see Willet's Fall Catalog. Price: One bushel $\$ 1.75$; 5 to 10 bushels at $\$ 1.50 ; 25$ bushels at $\$ 1.40$ per bushel. GEORGIA BURT OATS-Practically the only spring oats-far better and safer than any other oats sown in oats-far better and safer than any other oats sown in spring-and when oats are winter killed these oats are in-
valuable. The Burt Oat is also good oat sown in fall; three weeks earlier than Native Rust-proof. The most popular of the early varieties of oats which are largely used in Tennessee and the Southern States, both for hay crop as well as grain. The true stock of Burt Oats are unusually free from rust, heatlhy, clean, make a vigorous growth of straw besides a good yield of grain. Very desirable where a quick crop of eats is needed. Price: One bushel \$1.65; 5 bushels at $\$ 1.50 ; 10$ bushels at $\$ 1.40$ per bushel. Get prices in large amounts.

TURF, or GRAZING OATS-Do not resemble oats till they head; look like rye, and look, too, like orchard grass. No cold whatever seems to kill them. They can be winter grazed, and afterwards will grow off and head out in spring like rye. Blade as wide as wheat; 10 days later than Rustproof oats. For particulars, see Willet's Fall Catalog. Price: One bushel $\$ 2.00 ; 5$ bushels at $\$ 1.75 ; 10$ bushels at $\$ 1.65$ per bushel. Get prices in large amounts.

GENUINE TEXAS RUST-PROOF UATS-A trifle later than Appler; smaller in size, more bearded and will more easily cold kill-because, perhaps, planted the previous sea- son in the spring. For particulars, see Willet's Fall Catbushels at $\$ 1.25$ per bushel. Get prices in large amounts.

\section{Rye (56 Lbs. to Bushel.)}

NATIVE GEORGIA RYE-(56 pounds to bushel.) It stools heavily $1 / 4$ can be grazed several times and then allowed to go to seed; cut and feed green has made 10 tons green food per acre in five months. Our Georgia fall sown rye is called "Black Rye," Plant in September or October and through January and into spring, one bushel per acre: Graze December 1st to April 15th. Rye can be planted for late fall and winter grazing, at the last laying by of cotton. For particulars, see Willet's Fall Catalog. Get prices in large $\$ 3.25$;

BEECH ISLAND RYE-There are many farmers who believe that a rye grown below the latitude of Augusta is more liable to grow tall and never trail, than rye grown in Middle Georgia. Beech Island Rye is supposed to be the tallest of all ryes. For particulars, see Willet's Fall Catalog. Price: Peck $\$ 1.25$; bushel $\$ 3.75 ; 5$ bushels at $\$ 3.50$ per bushel. Get prices in large amounts.

ABRUZZI RYE - (Italian)-Seed are 25 per cent larger, less elongated and fatter than native rye, and have a bluish cast. A tremendous yielder of grain and forage. Best rye known for grazing, cover crop or seed purposes, and 50 per cent more prolific, and earlier than the other ryes. In tremendous demand for winter cover crops in cotton middles or otherwise. Makes 25 to 30 bushels per acre. Sometimes 15 stools per seed, each stool carrying an 8 -inch seed head. Upright, never trails. Six feet high. Will supplant ali other ryes. Will stand 10 degrees below zero. Price:

THE NEW "ROSEN" RYE-It stools remarkably. Straw is stiff and stands up. Grain is possibly the largest of all ryes-grayish white in color. In Virginia more satisfactory than Abruzzi. In Michigan is superceding all other ryes. Matures ten days later than Abruzzi. Withstands any cold. Probably a better winter grazing matter than Abruzzi, and as productive or more productive in seeding. A most valuable new rye from Russia. See Fall Catalog. Price: Peck $\$ 1.25$; bushel $\$ 3.75 ; 5$ bushels at $\$ 3.50$ per bu
WHEAT-( 60 lbs. to bushel. $)$ - Wheat is never cold-kill ed like oats. Should make 20 bushels per acre. Plant to January 15th. If rust comes, cut wheat in milk (beardless varieties), and save for hay. Get Bulletin No 179 on

"Wheat.; For full particulars, see Willet's Fall Catalog.

Beardiess or smooth Head Varieties we recommend for this section: Blue Stem. Early Red May, Leap's Prolific and Currell's Prolific. Prices: Peck $\$ 1.25$; bushel $\$ 4.00$ 5 bushels at $\$ 3.75$ per bushel. Bearded or Long Berry Varieties which we recommend for this section: Red Wonder and Bearded Fulcaster. Price: Peck, \$1.25; bushel $\$ 4.00 ; 5$ bushels $\$ 3.75$ per bushel.

WILIET'S GRAIN GRAZING MIXTURE-One of the best combination grazing mixtures we know. Is composed of Rye, Wheat, Beardless Barley, Turf Oats and Vetch. Use at the rate of 2 bushels per acre. Price: Bushel $\$ 3.25 ; 5$ bushels $\$ 3.00 ; 10$ bushels $\$ 2.85$ per bushel.

\section{Vetches, Clovers and Grasses}

\section{SUITABLE FOR THE SOUTH GET OUR FALL CATALOGUE FOR FULL DESCRIPTIONS}

NOTE-“Leguminous Crops in North Carolina." - A good bulletin. Experimental Station, Raleigh, N. C. Get it. A CULTURE FOR VETCH GROWING-Vetches grow to 5 feet and tiller heavily-Villosa 5 to 12 per cent, and Vicia Sativa, 4 to 6 . Sow August to January 15th.

Our best winter legume-vastly enriching the soil in winter. For full particulars, see Willet's Fall Catalog.

VETCHES IN COTTON FIELDS-Plant with harrow at last plowing, or about August 1st, or at first picking of cotton, 30 pounds vetches, 1 peck of oats. In winter, cotton stalks may be pulled out, and in May retches cut for hay. This soil enrichment and for the making of two crops per- year is coming universally into vogue.

The vetches will add 25 to 50 per cent to the fertility of cotton lands.

AUGUSTA VETCH, NARROW LEAF, VICIA ANGUSTIFOLIA-Sow August until February 15th. Not so tall as other vetches. Reseeds itself. The seed are small and it carries less seed cost than other vetches. We plant alone 25 pounds per acre, or with two quarts of oats, or half and half with Crimson Clover. Our earliest vetch, coming off and maturing April 15th to May 15th. Easier cured than and maturing April 15th to May 15th. Easier cured than Sativa; three weeks earlier than Hairy. The plant does Sativa; three weeks earlier than Hairy. The plant does
not seed synchronously. For hay, plant 20 pounds vetch and one bushel oats-same amounts for grazing or turning under. Its earliness allows cotton and corn and rice crops (without guano) to be grown as following it. It has been scattered through Augusta oats, throughout the South in a small way. In reseeding it germinates so slowly that it may gradually come up from Oct to Dec. Holds its own against native grasses, being wild and hardy. Can be gfazed. Seeds from bottom of the plant successively up to the top, through a season of three or four weeks. The hay, therefore, is a mixed matter of both grain and hay, while other hays are simply hay alone; therefore, "Augusta cattle better carries more feeding value, and is liked by $20 \mathrm{c} ; 5$ to 10 pounds $15 \mathrm{c} ; 25$ to 50 pounds $12 \mathrm{c} ; 100$ pounds $1.0 c$

VICIA VILLOSA, or HAIRY VETCH- $(60$ pounds to bushel.) An annual winter legume; 10 days later than Sativa; can be planted alone or in mixture. Nuch hardier than Sativa. Seed smaller than Sativa-30 to 40 pounds to the acre should be planted. The blooms are a beautiful purple, and appear in streamers on the end of the limbs. To grass so beautiful as hairy vetch. Plant till January 15th. For full particulars, see Willet's Fall Catalog.

Price: Cne pound $30 \mathrm{c} ; 10$ pounds at $28 \mathrm{c} ; 25$ to 50 pounc's at $25 \mathrm{c}$ per pound.

VICIA SATIVA, or OREGON, or ENGLISH WINTER VETCH-A legume. Stands climate here at Augusta excellently. For the latitude below here, usually no trouble in Sativa being cold-killed. Stands up better, is less twin- 
ing and cheaper than Hairy Vetch. Largely grown at Augusta, Ga. More easily cured than Hairy; an annual; tillers or stools 4 to 6 stalks per seed; seed larger than Hairy. Grows 3 to 5 feet, slightly earlier than Villosa. Usually cut here about May 10 th. Hay is of highest quality. Sow 40 pounds to the acre from August to January. 15th. Price: One pound 20 :

\section{CLOVERS}

GREEN LEGUMES TURNED UNDER-Five tons of the varied legumes, as turned under green, will yield in pounds nitrogen for soil improvement, as follows, viz.: Vetch, 55 pounds; crimson clover, 46 pounds; alfalfa, 74 pounds, and Burr Clover, 85 pounds.

ALFALFA, or LUCERNE CLOVER-A legume and soil. renovator. U'se Mulford Cultures; 1 -acre size, $\$ 1.50 ; 5$-acre size, $\$ 5.00$-all postpaid. (Medicago Sativa.) 60 pounds to bushel. Stools or multiplies and stems heavily -30 to 40 stalks from one root. These throw out numberless intertwined branches; average growth 3 feet. Drill or broadcast, 20 pounds per acre, spring or fall. Cut before blooming 4 to 6 times a season. Stand once set, lasts a lifetime. Deep feeder-needs a loose soil; grown throughout America; better than red clover. In place of successive cuttings, alfalfa can be cut in June and then pas tured until October 1st. Pound for pound, it has equal feeding value with bran or the grains. Thousands of cars of ground alfalfa mixed with ground grains, which is perfect ration for horses and cows, are now. annually used. At the Government Diversity Farm in Alabama there was netted $\$ 51$ an acre on alfalfa-five cuttings, $\$ 12$ per ton for hay on land rated at $\$ 15$ per acre. Georgia Agl. Col. made $61 / 2$ tons per acre with five cuttings. Best in Georgia to drill, 3-foot rows, and clean cultivate for several years the middle till weeds are driven out, then plant middles. Mississippi is growing it well in her black lands2,000 acres in one county. Alfalfa will lap when grown in $21 / 2$-foot rows. On a small scale, if a few rows are grown in a garden or around the border of the garden walks, it

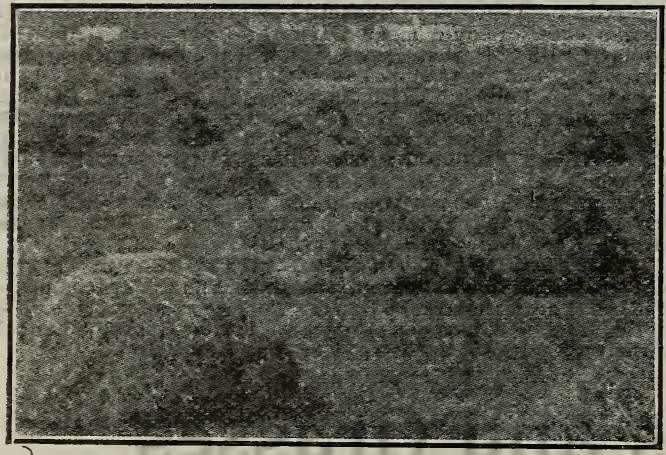

ALFALFA FIELD.

A Field of Alfalfa Near Augusta, Making Four Tons Acre. will furnish for many months in the year, in successive cuttings, goodly amounts of green forage, year after year, without replanting. A Thomasville, Ga., grower planted 13 acres in alfalfa in October and in May, first cutting. cut 15 tons of hay. The root plants had gone down four feet, eight inches. Many people grow alfalfa successfully by planting 15 or 20 pounds along with spring oats in February. Price: One pound $35 \mathrm{c} ; 5$ to 10 pounds $30 \mathrm{c}$; 25 to 50 pounds $28 \mathrm{c} ; 100$ pounds $25 \mathrm{c}$.

HAIRY PERUVIAN ALFALFA-Is fast supplanting in the Southwest the other 9 types of alfalfa. It carries a very much longer season and therefore carries more cuttings, and yields according to all tests $1 \frac{1 / 4}{4}$ to $1 \frac{1 / 2}{2}$ ton more of hay per acre than other types; the hay is of fines quality because of the greater abundance of leaves which are much larger than the usual types. Grows at a lower temperature than other alfalfas, and hence grows the earlier in spring and the later in fall. Remarkable to say, this alfalfa keeps practically green and an edible proposition throughout the whole year, while other alfalfas go down at frost. Takes on a fuzz in winter which protects the plant. Leaves off fuzz in summer. Large leaves grow up to the very top of the plant.

While fall is the best time for planting, we advise our friends early this spring to try out this type. Plant 10 lbs. per acre as drilled; make rows $2 \frac{1}{2}$ feet apart; cul tivate middles, free of grass for two years, and then plant middles. Price: One $1 \mathrm{~b} .65 \mathrm{c} ; 5 \mathrm{lbs}, 55 \mathrm{c} ; 10 \mathrm{lbs}$. $60 \mathrm{c}$ a $1 \mathrm{~b}$.
GEORGIA BURR CLOVER or SPOTTED BURR CIO-

VER-(See cut.) 10 pounds to bushel.) (Medicago Arabic.) Closer jointed, has much more foliage, is a great deal hardier than the California Burr. Clover, which is somewhat bunched and is sold much cheaper. Get Farmers (U. S.) Bulletin No. $693 \ldots$ Sold in burrs, unhulled. A

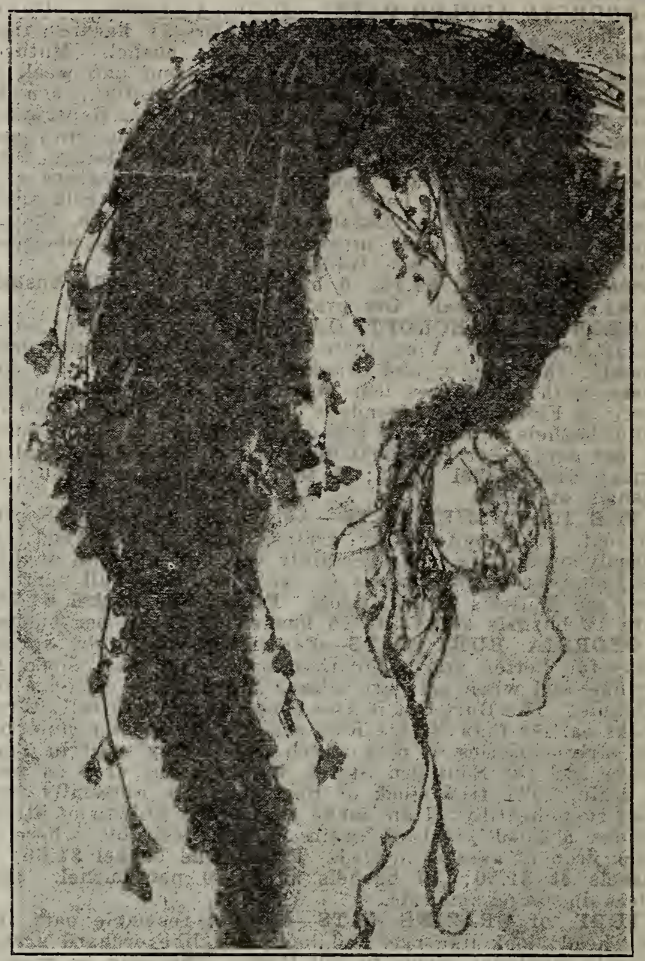

Burr Clover.

perennial legume. Ascending and branching. The cut is a plant covering $21 / 2$ to 4 feet square; carries 40 stems and each stem with-about 60 burrs; each burr 3 to 7 seed-the plant having about 2,400 burrs and 12,000 seed. Always wet and roll seed well in ashes or dust and can then be sown broadcast like cow peas. A hardy rank grower, 15 to 30 inches high, dense mass fiber roots. penetrating 12 to 18 inches, large nitrogen gatherer. Plant two bushels per acre. Sow July to middle of November. Smoothly harrow land and cover only one-third inch in depth. Matures about May 20th. When seeds ripen, plant land in corn or cotton, etc. For cattle and hogs scatter seed in corn late in summer, harrowing over with "Joe Harrow' '; or break land and sow in August, harrowing in: comes up in October. Turn cattle and hoos in in winter up to April 1st, and then let it go to seed. Furnishes immense grazing for cattle, sheep and hogs in winter. One planting lasts a lifetime. Burr Clover and Bermuda grass make a splendid combination for pasture or lawn, which is green all the year. Sow the Burr Clover ( 5 to 6 seed are in each burr) in September or October by running a disc over the Bermuda sod, then sow Burr Clover and drag the land; or sow on top of the ground. After planting June or July cow peas, sow Burr Clover on top of ground and mow cow peas later for hay, leaving clover undisturbed. Burrs carry inoculation. Good crop to plant between corn or cotton rows. Five tons of green Burr Clover, turned under, puts 85 pounds of nitrogen-into the soil. At South Carolina Fair exhibit showed cotton after two years of Burr Clover turned under, increased 300 per cent; and corn after two years of Burr Clover, showing the same results as corn using 900 pounds per acre of guano. Seed were planted in fall in cotton middles: and in the spring cotton and corn were planted leaving the middles or balks undisturbed, which Burr Clover after reseeding itself on the ground late in May was turned under. Never cultivate a field of it after August 25th. One pound 24c; 1 bushel $\$ 1.50 ; 5$ to 10 bushels $\$ 1.35 ; 25$ to 50 bushels $\$ 1.25$.

CAIIFORNIA BURR CLOVER-(Medicago Denticulata.) Use Mulford Cultures; 1 acre-size, $\$ 1.50 ; 5$-acre size for $\$ 5.00$, all postpaid. A perennial legume. Close kin to Georgia Burr. Not so hardy as Georgia Burr, nor is it so 
large. Used largely in California and Texas. Sell only the hulled. The burr is large and smooth; ends flattened, as compared with the burr of the Georgia Burr. The hulled seed are 15 per cent smaller and not so humpbacked hull are shorter. The Georgia Burr has spines all over the and are shorter. The Georgia Burr has spines all over the itself, or with Bermuda grass or winter vetches. Price: itself, or with Bermuda grass or winter vetches. Price:
One pound $25 \mathrm{c} ; 5$ to 10 pounds $22 \mathrm{c} ; 25$ to 50 pounds $20 \mathrm{c}$. JAPAN CLOVER-(Lespedeza Striata.) Use Mulford Cultures. 1 -acre size, $\$ 1.50$, postpaid; 5 -acre size for $\$ 5.00$; all postpaid. A perennial legume. Southern seed trade supplied, 25 pounds to bushel. Grows anywhere; is tenacious in any soil: lasts always; well known now in the South. Sow in fall or spring in permanent pastures by scarifying surface with disc harrow. Is eaten greedily by stock-June until frost. In some soils grows 20 inches high and is mowed, two tons to acre. Rich soil grows 30 inches. Appears in May. Can Plant in spring 25 pounds per acre alone, or fall with rye and oats. Spreading by per acre alone, or fall with rye and oats. Spreading by natural means rapidly through the whole South. Select well-drained bottom or fairly fertile upland, break in winter, let it lie till February 15 th, disc harrow and roll or
drag with a log. Sow one bushel seed and drag again with a very light log or roll. Cut September to November, as soon after blossoming as convenient. Leave strip of 6 inches around the mower for resetting. Thoroughly drag these 6-inch strips and the stand will be perfect the second year. Will grow on any land, sweet or sour. Stock and hogs are fond of it. Scatter it in the woods or pastures fall or spring. Sow seed in fields on top of ground after spring oats are planted. For reseeding do not cut till seed on lower stem have ripened, which then scatter. Price: 5 to $10 \mathrm{lbs}$. at $50 \mathrm{c} ; 25$ to $50 \mathrm{lbs}$. at $45 \mathrm{c} ; 100 \mathrm{lbs}$. at $40 \mathrm{c} \mathrm{lb}$. SCARLET OR CRIMSON CLOVER-(Trifolium Incarnatum.) Useful for soil improvement, late April or May cutting, and early spring grazing. Can be sown at second picking in cotton fields; adds 25 per cent to soil fertility when plowed under before cotton planting. Sow September or October, 20 pounds per acre, and cover lightly. Can pasture in December and January and still yield. Planted in corn last plowing, and plowed under in the spring, it can Catalog. Price: $1 \mathrm{lb} .35 \mathrm{c} ; 5$ to $10 \mathrm{lbs}, 30 \mathrm{c} ; 25$ to $50 \mathrm{lbs}$. $28 \mathrm{c} ; 100$ lbs. $25 \mathrm{c}$.

CRIMSON CLOVER IN THE CHAFF-(Native grown.) Always sow on top of the ground without covering. Thirty pounds per acre in chaff gives as good a stand as $15 \mathrm{lbs}$. hulled. The husks hold considerable moisture, which germinates the seed, for it gathers moisture daily from the dew. At the same time the continual moisture of the husk hew. At the same time the continual moisture of the husk $25 \mathrm{c} ; 10 \mathrm{lbs}$. 22c; $50 \mathrm{lbs}$. 20c; $100 \mathrm{lbs}$. $18 \mathrm{c} \mathrm{lb}$.
ALSIKE CLOVER-(Trifolium Hybridum.) Swedish clover. A legume. Is valuable for pasturage or soiling; makes finest hay. Perennial, sow 10 to 15 lbs. per acre Gers thicker, makes better hay and grazing than ver. Is hardier. The flowers are a distinct light pink and $1 \mathrm{lb} .50 \mathrm{c} ; 5$ to $10 \mathrm{lbs}$. $45 \mathrm{c} ; 25$ to $50 \mathrm{lbs}$. $42 \mathrm{c} ; 100 \mathrm{lbs} .40 \mathrm{c}$

WHITE CLOVER-(Trifolium Repens.) Not a heavy producer, but invaluable in permanent pastures and lawns. Sow 12 lbs. to acre in fall or spring. Price: $1 \mathrm{lb} .70 \mathrm{c}$; 5 to $10 \mathrm{lbs}$. $65 \mathrm{c} ; 25$ to $50 \mathrm{lbs}$. $60 \mathrm{c}$.

BLACK MEDIC-This clover seed heretofore unobtainable can now be had; can be substituted for Burr Clove and Crimson Clover, making in autumn, winter and early spring an excellent cover crop and good for soil improvement and an excellent annual legume for pasturage. Excellent to scarify in early fall, on Bermuda grass pastures. Hardier than Crimson Clover. Sow in Bermuda pastures 8 to 10 pounds, and sow alone 15 pounds per acre. Excellent in corn and cotton middles. Seed can be home-saved by threshing; or can be left to reseed ground following fall. Not used for spring sowing. See Fall Catalog. Price: $1 \mathrm{lb} .75 \mathrm{c} ; 5$ to $10 \mathrm{lbs}$. $70 \mathrm{c} ; 25$ to $50 \mathrm{lbs}$. $65 \mathrm{c}$ GEORGIA MELIILOTUS ALBA, or BOKHARA CLO VER-A legume. Use TMulford Cultures; 1-acre size, $\$ 1.50$. 5 -acre size for $\$ 5.00 \div$ all postpaid. 30 lbs. to bushel. Sow 1 bushel to acre, in March or April. Can be sown in the fall with grain, and when grain is cut off in spring clover will come out and be ready to cut for hay in a short time. One of the best crops for enriching soil. Can be pastured in spring and summer, and plowed under in the fall. When eut for hay the cutting should be done when fall. When cut for hay the cutting should be done whell black soil is best. Once planted, always planted. Fine hay crop-several cuttings. Begin cutting in June and before seeding. Does not seed first year, but reproduces from roots second year. Cut hay, and then allow to go to seed. Will reseed as long as the land is unbroken. Grows on soils too poor for clover or alfalfa. Grower says: "I cut per acre two tons in June, made a seed crop in August, and made a short hay crop later. Grows 5 feet high.' Makes water white honey-blooms May to August. Grows largely with Johnson Grass. making the sweetest of all
hays. First crop will be Mel Alba, and other cutitings will be mixed Johnson and Mel Alba. Cut about 20 inches high about May 10th. Seeds a bout July 15 th. Always reseeds as it begins seeding near ground-parties about here have grown it half a dozen years with Johnson without reseeding. We sell Mel Alba in the burr. (Never use the yellow type.) Price, native grown in the burr (30 lbs.): $1 \mathrm{lb} .45 \mathrm{c} ; 5$ to $10 \mathrm{lbs}$. at $42 \mathrm{c} ; 25$ to $50 \mathrm{lbs}$. at $40 \mathrm{c} ; 100$ lbs. at $36 \mathrm{c} \mathrm{lb}$.

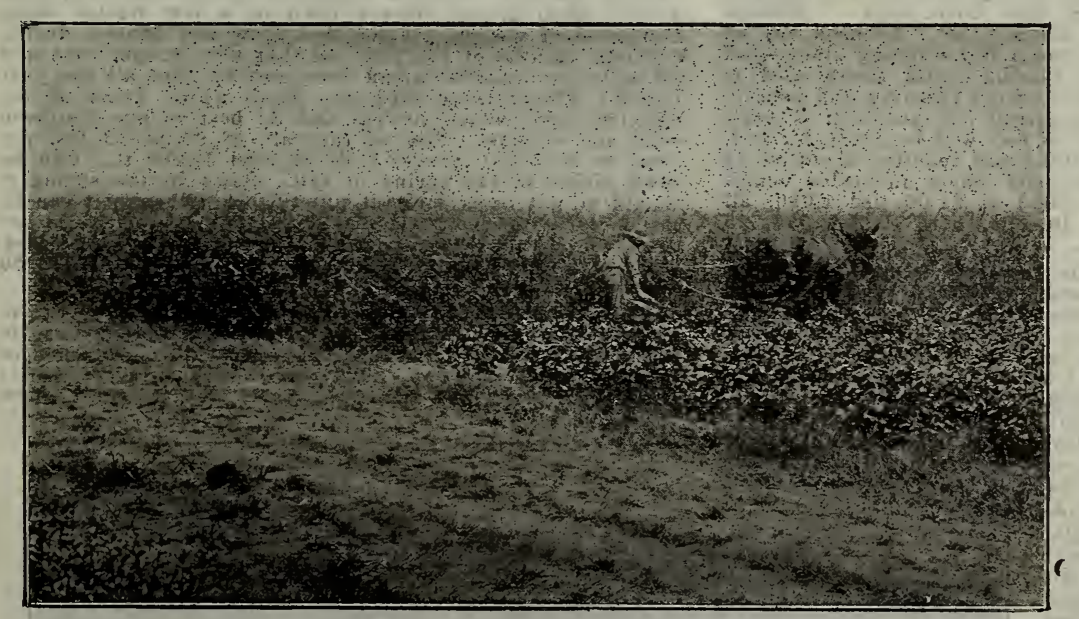

A Field of Sudan Grass.

LATE WHITE BLOOMING CRIMSON CLOVER-A legume. Is about three weeks later; makes a larger growth by 25 per cent; yields more hay and foliage and grazing than the regular early blooming crimson-headed clover. Plant same time as the Early Crimson. For full particulars see Willet's Fall Catalog. Price: $1 \mathrm{lb}$. 35c; 5 to 10 lbs. $30 \mathrm{c} ; 25$ to $50 \mathrm{lbs} .28 \mathrm{c} ; 100 \mathrm{lbs}$. $25 \mathrm{c}$.

RED CLOVER-(Trifolium Pratense.) A legume. Use Mulford Cultures. Sow broadcast in spring, September or October, $15 \mathrm{lbs}$. to the acre, or sow with any spring grain as early as ground is suitable for plowing; needs a stiff as early as ground is suitable for plowing; needs a stiff
soil. The most widely cultivated of all pasturage plants soil. The most widely cultivated of all pasturage plants
for pasture, hay and enricher of soil. Price: $1 \mathrm{lb}$. 65c; 5 to 10 lbs. $60 \mathrm{c} ; 25$ to 50 lbs. $55 \mathrm{c} ; 100 \mathrm{lbs}$. $50 \mathrm{c}$.

\section{GRASSES}

SUDAN GRASS-(See Cut.) (Andro Sorg. Var.) A new African sweet grass, fine stemmed like Johnson. An annual. Plant spring, or in summer here within 80 days of frost, in 30 -inch rows 5 to 8 lbs. bloom, and 45 days later can cut again. Fhree cuttings per season and 3 or 4 tons total per acre Grows 5 to 8 tieet, stools 20 to 40 per seed. Firect,
leafy stem. $1,00 \mathrm{ks}$ like Johnson, but is more leafy, and sweeter. Root system like oats-never a pest. Makes 600 lbs. seed per acre-1,800 seed per head. In Florida made 3 tons first cutting; month af ter was waist bigh.
Sweet, green or eured; is eaten ravenously. Probably the original form of sorghum. A North Georgia man writes us: "Sudan Grass bought of you turned out fine: it is certainly a wonderful plant. Made three full cuttings, at the rate of 6 tons per acre." Plant up to August 1st; usually planted in 14 to 24 -in. rows, 8 lbs. per acre. So sweet it is that the dried fodder after threshing is greedily eaten. Cut with a mower for hay just after full bloom, it renews its growth promptly and gives another cutting in perhaps 40 days. Stools abundantly after first cutting, sometimes as much as 100 stools per seed, and the second and third cuttings are fine stemmed. At Augusta, June, showed height of $5 \frac{1 / 2}{2}$ feet, 32 stools per one seed: June, showed height of $51 / 2$ feet, 32 stools per one seed:
length of root, 14 inches. Augusta parties who have used it here for three years claim it to be the best green-cutting grass. It grew here at Augusta this past year up to $8 \frac{1 / 2}{2}$ 
feet. Price: $1 \mathrm{lb}, 40 \mathrm{c} ; 5$ to $10 \mathrm{lbs}, 35 \mathrm{c} ; 25$ to $50 \mathrm{lbs} .30 \mathrm{c}$; $100 \mathrm{lbs}$. $25 \mathrm{c} \mathrm{lb}$

NATAL GRASS-(Tracholaena Rosea.) From Africa. In large use in Florida, where it is called Australian Red Top, and is growing in popular use. Used for hay or pas-

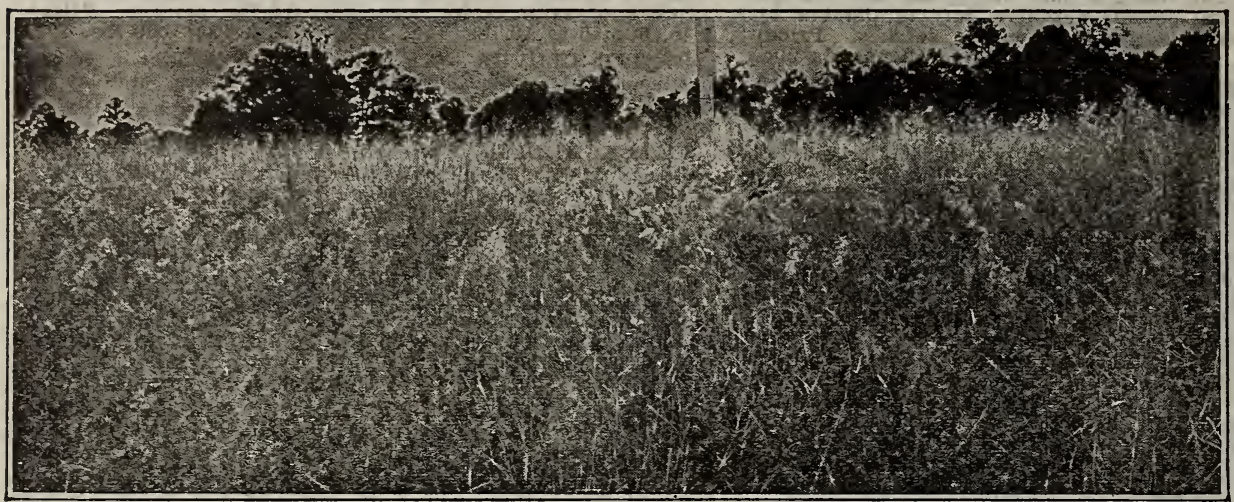

Natal Grass.

ture. Spreads rapidly. Height 2 or 4 feet. Stools heavily. Sreads rapidy. ily; sometimes 100 to the. seed. An annual, but reseeds 20 degrees cold. Comes up voluntarily after melons, potatoes and oats. Excellent late summer, fall and winter grazing. Hay as good as timothy. Comes early and stays late. Blooms all the time. Sow seed, drill or broadcast 6 lbs. per acre. Requires considerable moisture for germination. Some growers say May 1 st is the best planting time, though they set the time from February to July. Grows in clumps. Deep root system. Stools can be subdivided and transplanted; 80 days from seeding to maturity; three cuttings. Spreads, but can be eradicated by cultivation or cutting before seeding. Large fluffy seed heads. Seed matures on the Gulf late in October. Florida grower says: "Would rather have a field of Natal than Orange. Three cuttings and each gives one or one and a half tons per acre. We plant almost any time 5 lbs. per acre or transplant from root system. Grows well in winter. Seeds blow abroad and take root.", One Florida grower says: "In orange orchard my Natal gave four cuttingshalf ton each." "This hay has largely shut out timothy hay importation in Florida. U. S. Agri. Dept. says: "Florida land seeded to Natal carries extra value. As good hay as timothy. Florida should become a hay-shipping state-and hay of finest quality." In Florida Natal Grass seed is sown in melon fields at time of melon ripening and usually two crops of hay are then gathered. If the seed is sown about May 1st, the first crop of hay will be ready for harvesting about July 15th. Natal grass requires about 80 to 85 days from seeding to maturity under favorable conditions. 1,000 for $\$ 1.25$ or 5,000 at $\$ 1.00$ per 1,000 , all postpaid. Prices of seed, $1 \mathrm{lb}, 60 \mathrm{c} ; 5$ to $10 \mathrm{lbs}$. $50 \mathrm{c} ; 25$ to 50 lbs. $45 \mathrm{c} ; 100 \mathrm{lbs}$. $40 \mathrm{c}$.

RHODES GRASS-(Chloris Gayana.) New. From Africa. A perennial above 20 degrees climate, and an annual at below 18 degrees. Seed resembles Bluegrass. Hay palatable and nutritious, yielding sometimes six tons per acre, three cuttings. Plant in spring; cut from May until September. Can be propagated from the running branches like Bermuda. Easily eradicated. Plant lightly on smoothed land in wet seasons and roll,

8 lbs. per acre, in April, May, October and November. Grows continuously throughout the year. Good grazing. Blade wide as rye system, smaller than oats. Augusta grower says he tried 50 grasses on his sandy soils, and Rhodes is best of all. Easily cured. 4 feet high. Plant sends out runners, which take root and spread. Is also excellent for grazing purposes. It keeps green until cut back by severe frost, and then starts growing again as soon as warm weather returns. Well adapted to occupying land permanently. On the drained lands of Central and South Florida enormous yields are made; they prefer planting February through June. Noeds moisture for germination.

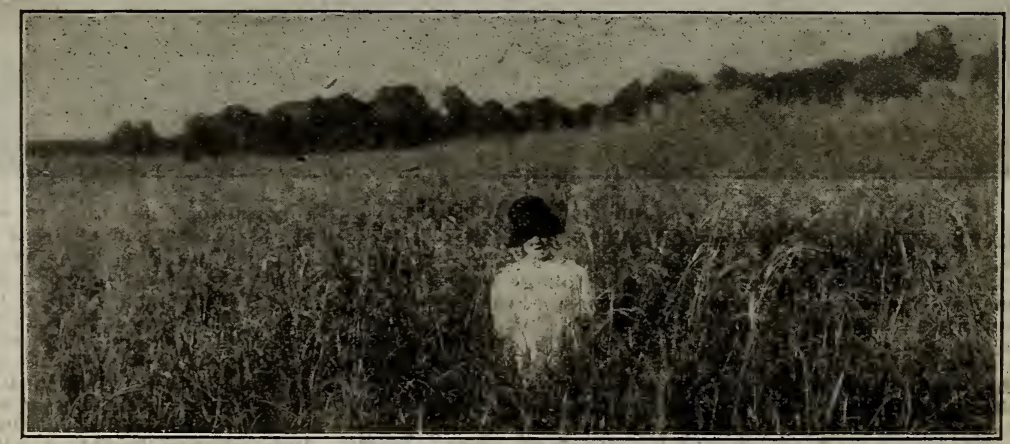

Bhodes Grass
Does well in sandy land; best adapted to low moist soil. In Florida Rhodes is largely used for pasturage, turning off cattle about July 1 st and let it grow until November, when it is used for winter pasture. Keeps green all winter. Price: $1 \mathrm{lb}$. $90 \mathrm{c} ; 5$ to $10 \mathrm{lbs}$. $85 \mathrm{c} ; 25$ to $50 \mathrm{lbs}$. $80 \mathrm{c}$ !b.

J O H N S O N GRASS - (Sorg h u m Halepense.) $28 \mathrm{lbs}$. to bu.) Known, too, as Means Grass, and falsely as Guinea. son Grass are son Grass are the standard $\mathrm{Au}$ gusta hay farm mixtures. Plant as soon as frost dis a p p e a s through June, 30 to 40 lbs. to fore head flowfore head flow-
ers ; 3 to 5 cuttings per season. Withstands drought; yields heavy c r o p s year after year without resetting though ground needs, each fall, disc harrowing. Do not let go to seed; spreads if you do; the root system develops only after plant seeds. Tender when young, making immense crops; hardy. Known, too, as Cuban Grassin large use there. We have grown Johnson here at Augusta for 75 years consecutively; this is a large distributing point of Johnson Grass hay. Large areas of Johnson Grass are to be found in Alabama, Texas and Mississippi. A few years ago these acres were thought to be quite without value, but today they, on account of the high quality and easy sale of Johnson Grass hay, are exceedingly raluable. Good combination with Bermuda, oats, vetch and crimson clover. Our cheapest hay grass, yet it contains more nutriment than timothy. In 1915 the English Gov. in feding army mules at New Orleans used it regardless in feeding army mules at New Orleans used it regardless of price in preference to timothy.
$25 \mathrm{lbs} .45 \mathrm{c} ; 50$ to $100 \mathrm{lbs}$. $40 \mathrm{c} \mathrm{lb}$.

TIMOTHY-This is one of the more strictly hay grasses, valuable for $\mathrm{N}$ Ga, ala and Miss and in mountainous sections of the Carolinas. Sow at the rate of 12 to 16 lbs. per acre. Price: $1 \mathrm{lb}$. $25 \mathrm{c}$; bu. $\$ 4.50$.

WILLET'S EVERGREEN LAWN AND PARK GRASS(14 lbs. to bu.) Willet's Evergreen Lawn Grass will form a rich, deep green, velvety lawn in a few weeks' time. Composed of various grasses that grow and flourish during different months of the year, so that with proper care and attention a beautiful green lawn can be kept all the year round. The grasses used are those which years of experience have shown success and do best in our S Juthern soils and climate. Sow at the rate of 60 to $75 \mathrm{lbs}$. per acre, or for small yards, $1 \mathrm{lb}$. to area $10 \times 10 \mathrm{ft}$. Can be sown either in the spring or fall. Sown in the spring it should be put in as early as practicable, although it can be satisfactorily seeded as late as the month of April. Do not use stable manure-makes weeds and miscellaneous grasses. Price of Lawn Grass: $1 \mathrm{lb}, 35 \mathrm{c} ; 5$ to $10 \mathrm{lbs}$. 30c; 25 to 50 lbs. 28c.

ORCHARD GRASS-(Dactylis Glomerata) (14 lbs, to bu.) Germinates within 1 to 2 weeks. Sow 2 bus. to acre. Fall or spring. Excellent perennial. Commences spring growth in Feb. Ready for hay cutting in April ; graze then until hot summer. Early autumn starts new 
set of leaves, making rich pasturage, remaining green all fall and winter. Mixes well with Red Top. A good shady woodland pasture. No better winter gg
heary clay lands. $1 \mathrm{lb}$. $40 \mathrm{c} ;$ bu. $\$ 4,50$.

KENTUCKY BLUE GRASS-(Poa Pratensis.) $14 \mathrm{lbs}$. to bu.) Germinates within 2 to 3 weeks. This grass is too well known to need a description. An excellent pasture grass. Usually sown in fall with other grasses-orchard grass, clover, etc.; also used in lawns and woodlands. Sow two bushels per acre. A perennial for hard-soiled low only. $1 \mathrm{lb}$. $35 \mathrm{c}$; bu. $\$ 4.25$

HERDS, or RED TOP-(Agrostis Vulgaris.) (10 lbs. to bu.) Good perennial. Generally sown on permanent moist land pastures. It is best when fed down close as a forage plant; not killed by overflows; improves with age each year. Its chief value is a pasture grass; altho. it is used largely in some sections for hay. It is used largely, too, in Sow in fall or spring, 2 bus. to acre. Can be successfully Sow in fall or spring, 2 bus. to acre Can be successfully The cheap kind is sold for half this price, but in the end is more expensive. $1 \mathrm{lb} .25 \mathrm{c}$; bus. $\$ 2.25$.

BERMUDA GRASS SEED-(Cynodon Dactylon.) (Couch Grass or Joint Grass.) Germinates within 2 or 3 weeks. A perennial sun-loving grass, spreading extensively by creeping stems. The most valuable of all grasses for pastures in the South. Grazing can be had from May to middle of Nov. Every 3 or 5 years disc harrow the sod bound soil in spring. Excellent soil binder. Ton rietics of soil. On rich land 2 to 4 cuttings can be had ( 2 ft. high) yeariy. Seed are planted (6 to $81 \mathrm{bs}$. per acre in ft. high yeariy. Seed are planted 6 to 8 los. per ace in with a roller. After the last cutting in the fall, plow the with a roller. After the last cutting in the fall, plow the
land and sow oats or vetch, or a mixture of the two. Soil should be thoroughly harrowed, both before and after the sowing, and if possible, smooth off with a heavy roller in order to give a level surface for mowing. The oats and vetches give a crop of hay in May and by July the Bermuda may be cut. For a combination with Burr Clover, which would give green pasture all the year, read our catalog description of "Georgia Burr Clover." Excellent, too, for lawns. Price: $1 \mathrm{lb} .75 \mathrm{c} ; 5$ to $10 \mathrm{lbs}$. at $60 \mathrm{c} ; 25$ to $50 \mathrm{lbs}$. at $50 \mathrm{c}$ por $\mathrm{lb}$.

BERMUDA GRASS ROOTS-Plant 25 to 50 bus. per acre. Grows anywhere; South's best grazer; soil preserver; terrace builder; stops washes; no heat hurts it; close cropping and tramping improrss it; of great value to cattle and hog man. Utilize Bermuda sod in winter by tearing it up and planting any of these: Oats, Rye, Burr. Clover, Vétch. Italian Rye Grass or Texas Blue Grass sets. It is best that these roots be set out in the spring months or early fall. Keep cuttings corered with wet earth till you are ready to plant. They can not be shipped and set out in extremely hot, dry weather, and it is best not to plant them, either, in mid-winter. Set out sets 1 ft. each way in premuda fields should be ripped up by a subsoil harrow in fall: These ruots often go down $6 \mathrm{ft}$. or more in the soil. Spring plantings are easily grown. Our principal Southern Lawn Grass used alone or with Burr Clover or Texas Blue Grass sets-combination making green effect all the year. Mixes well with Itailian Ray Grass and English Ray and Augusta Vetch. Our best grower says: "Separate roots into sprigs, cut them up with a feed or oat-cutter, and drop each sprig into furrows in the drill 12 inches apart in the furrow, and cover roots. Invaluable in the South for pasture hay and lawn purposes. To exterminate it, plow and winter-kill the roots and also shade in summer by large forage plants. Put up in $100-1 b$. bags, holding about 12 bu Prices: 1 bag $\$ 2.75 ; 5$ bags $\$ 2.50 ; 20$ bags $\$ 2.25$ per bag.

"GIANT" BERMUDA-(Paspalum Dist.) ' Valuable turf and pasture grass. Grows twice as fast and spreads twice does Bermuda; palatable; resists drought. Spreads above ground. Cut long runners to three inches, and plant cuttings in a furrow plowed three inches deep. 2,500 cut tings, $3 \times 6$ feet, plants an acre and ground will be quickly covered. Plant spring and summer. Price, postpaid, 100, $75 \mathrm{c} ; 500,60 \mathrm{c}$ per $100 ; 1,000, \$ 4.70 ;$ larger amounts, $\$ 3.75$ per $1,000.1000$ cuttings weigh about 15 pounds.

ITALIAN RYE GRASS-(Lolium Italicum.) (14 lbs. to bu.) Sow 40 to 60 lbs. per acre, in fair soil, Aug., Sept. Oct. Graze in winter. Makes abundant hay crop for Mch. or Apr. An annual. Makes 2 or 3 spring cuttings of hay. Seeds about May 1st. Wherever in the South where watering is impossible and where sandy soil and shade make lawn grass impossible Italian Rye will give largest and lawn grass impossible Italian Rye will give largest and finest results. See Willet's Fall Catalog. $1 \mathrm{lb}$. $25 \mathrm{c} ; 5$
$10 \mathrm{lbs}$. at $22 \mathrm{c} ; 25$ to $50 \mathrm{lbs}$. at $20 \mathrm{c} ; 100 \mathrm{lbs}$. at $18 \mathrm{c}$ lb.

ENGLISH PERENNIAL RYE GRASS-(Lolium Perenne.)

(14 lbs. to bu.) Sow about end of Oct. 40 to $60 \mathrm{lbs}$. per acre. Best adapted for lawn purposes and pasturage. Grows well on Bermuda grass sod, filling in the time in fall

ter and spring, when Bermuda is dormant. A quick, leafy matted growth for winter and spring grazing. Best adapted for pasture or lawn. Good for light sandy or heavy soil. at $20 \mathrm{c} ; 25$ to $50 \mathrm{lbs}$. at $18 \mathrm{c} ; 100 \mathrm{lbs}$. at $16 \mathrm{c} \mathrm{lb}$.

AWNLESS BROME GRASS-(Bromus Inermis.) Also called Hungarian Brome and Smooth Brome. Adapted to bare and sandy soil and withstands drought; not adapted to heavy wet soils. Better as a pasture grass than a hay crop. Good all the year round pasture gross. Almost erergreen in habit, growing during the entire winter. Sow 30 pounds $25 \mathrm{c}$ : 20 to $25 \mathrm{lbs}$. at $20 \mathrm{c}$; 50 to $100 \mathrm{lbs}$. at $18 \mathrm{c} \mathrm{lb}$.

RESCUE OR ARCTIC GRASS-(Bromus Unioloides.) Known, too, as Schrader's. Sow 30 pounds per acre in the

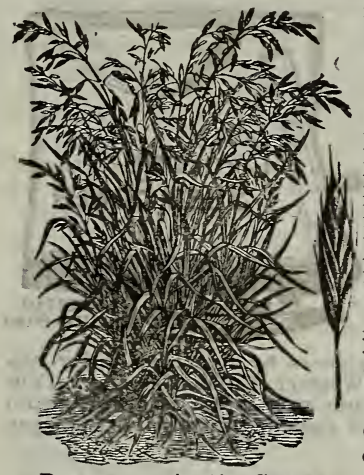

Rescue or Arctic Grass. fall. Ripens' seed in March, but for hay cut first crop and let second crop grow for a crop of seed. which allow mature and fall to the ground. Fine pasturage in winter months. Sisw with
Bermuda makes continuous year pästurage. Scarify Bermuda sod with dise harrow the Arctic Grass. For ful particulars see Willet's Fall Catalog., In North Georgia "Cheat", is falsely called
Arctic Grass. Price: One Arctic Grass. Price: One
lb. $25 \mathrm{c} ; 10$ to $25 \mathrm{lbs}$. 20c; 50 to 100 lbs. at $18 \mathrm{c} \mathrm{lb}$.

TALL MEADOW OAT GRASS - (Arrhena Avenaceum.) (11 pounds to bushel.) Evergreen grass in
Southern states. Related to the common oat. On sandy or gravelly soils succeeds ad mirably, growing 2 to 3 feet high. On rích, dry upland grows from 5 to 7 feet high. Sow in March or April and mow the same season; but for heavier yield better to sow in September or October. Ond of the most certain grasses to have a goid catch. Not less than 2 bushels per acre should be sown. Pisice: Cne 1b. 30c; 10 to $25 \mathrm{lbs}$. 25c; 50 to $100 \mathrm{lbs}$. at $20 \mathrm{c}$.

CARPET GRASS - (Paspalum Compressus.) Crop a total failure in the U. S., and seed can not be quoted 1919 by any one.

PASPALUM DILATATUM-Sow in spring, 5 to $10 \mathrm{lbs}$ per acre by hand, roll or plank under on harrowed land. A perennial. The great cattle permanent pasturage of tustralia, where one acre supports one cow year round. Grows 2 to 4 feet high. Make senormous pasturage, or several green cuttings. Grows in clumps; its broad leaves are near the ground. Mixes well with Bermuda. Known, also, by root stock and seed. Has crowfoot seed heads. Growth is sprawiing and in clumps, and spreads rapidiy. Has double feeding value of Bermuda and is a month earlier and also later for grazing. Plowing kills it. This grass is spreading naturally now in Georgia. Good amounts of Paspalum in Louisiana mixed with Japan Clover make good mixture. This grass has transformed New South Wales into nne of the greatest dairying countries in the world- -13 tons of green stuff per acre. Our city cut in her parks, etc., at least 150 tons of this splendid hay this past summer. Waist high in good lands. Known in Virginia and North Georgia
as Dallis Grass. Price: One $\mathrm{lb} . \$ 1.00 ; 5 \mathrm{lbs}$. at $90 \mathrm{c}$ per Ib.

GEORGIA “TEXAS BLUE GRASS” ROOTS-(Poa Arachnifern.) Perennial. Transplant sets or roots Aprì to November; run off rows 24 inches apart: drop sets 12 inches in rows: can be pushed into soil with an inch-wide stick; live easily. Cultivate first year with wide sweep; after this takes care of itself. Invaluable to dairymen in fall and winter; makes fine pastures from November to May. Do not too closely graze crop in summer. A mixed lawn of this and Bermuda is green all the year. Grows-2 to 3 feet high and thick; makes good cutting in spring; makes good lawn, and for terrace nothing superior. Price: postal packages add $15 \mathrm{c}$ per 1,000 sets.

KUDZU GRASS ROCTS-(Pueraria Thumbergians.) From Japan. Hay or pasturage. Broad leaf and very rapid grower. Grows from a tuberous root, takes root each joint of the vine. Cut at any time. Three or four cuttings. Covers ground, destroys other grasses and weeds. Fine for rolling washing lands for pasturage. A perennial. Plant in Florida November to June; in Georgia in March. 600 plants, $8 \times 10$ feet, sets an acre. We can't deliver later than March 20th. Plants are already inoculated and selfrooted. In Japan, its native habitat, is grown on rough, rocky land or steep bill sides impossible for cultivation, and in this country could be raised on lands too poor for otherwise profitable cultivation. One Georgia grower says:
"No plant whatever so valuable for hay or grazing on sandy 
coastal plain region. Am more and more pleased with it. I expect soon to put down 60 or 70 acres on very poor land. Two cuttings gave me two and a half tons per acre, and I practically lost one cutting, which should have been made June 15th." Kudzu is the only perennial forage legume that has made good in Florida. It does well on clay, limestone, and the better class of sandy soil. As for latitude even as high as Arlington, Va., it has produced two cuttings of hay per year, totolling five tons per acre. Price: Kudzu plants, 20 to 50 plants, $5 \mathrm{c}$ each, postpaid. 100 at $2 \frac{1}{2} \mathrm{c} ; 500$ at $2 \frac{1}{4} \mathrm{c} ; 1,000$ at $2 \mathrm{c}$ each for express.

\section{CYCLONE SEED SOWFR.}

A POPULAR SEEDER, AND EXTENSIVELY USED.

Guaranteed to distribute seed perfectly evenly ani? will not throw seed in an u p wa r d direction or against the operator, but direct and evenly to the land. Has automatic cutoff and regulator. Sows Clover, Timothy, Red Top, or Herds Grass, Alfalfa, Oats, Rye, Wheat, Millet Buckwheat, Turnips and other varieties of farm seeds. Also distributes bone dust, land plaster tage Price, $\$ 2.00$ each.

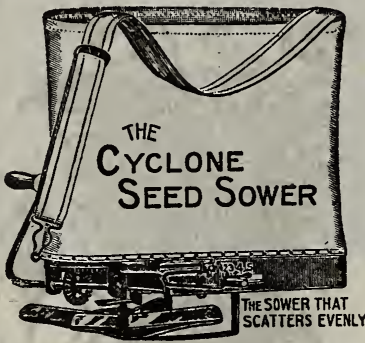

NOTE-Orders and remittances by telegraph under new arrangements made by the Western Union Telegraph Comany. You can now telegraph your order and the money in the same message. Call on your Western Union manager.

\section{Willet's Insecticides, Germi- cides, Spray Pumps, Etc.}

Get Best Price in Large Amounts. We Can't Mail Poisons.

FOR SAN JOSE SCALE ON PEACH TREES-Spray in late winter: Dry Lime-Sulfur, 10 pounds to 50 gallons of water, or Lime-Sulfur Solution, 1 gallon to 8 gallons of water. For summer spray: Use 2 to 3 pounds Dry LimeSulfur to 50 gallons of water in combination with 2 pounds Dry or 3 pounds Paste of Arsenate of Lead, for use on seed fruits, such as apples, pears, etc. Use 1 to $11 / 2$ pounds to 50 gallons of water in combination with 2 or pounds Arsenate of Lead for summe

FOR CURCULIO-Spray $1 \frac{1 / 2}{2}$ pounds Arsenate of Lead Paste or 2 pounds dried form together with 3 pounds slaked lime to each 50 gallons of water, and apply when and foliage.

FOR BROWN ROT-Mix 5 pounds Atomic Sulfur to each 50 gallons of water and apply three weeks after petals drop or the lead spraying. Never use Bordeaux Mixture for stone fruit trees.

PEACH LEAF CURE-Use lime sulphur same as for San Jose Scale.

IRISH POTATO BUGS-Dust with "Slug Shot"; or spray 2 lbs. Arsenate lead powder, or 2 lbs. Calc. Ars., or 3 pounds Arsenate lead paste, to 50 gallons water.

MEXICAN BOLL WEEVIL-Dust in morning on the dew-wet plants, 5 pounds powdered calcium arsenate per acre using Monarch Duster (see prices below). (Dusting is made at night or in the early morning before dew is off.) Get Farm Bulletin 731 .

RED SPIDER IN COTTON-Microscopic mite on under side of cotton leaf. Leaf shows red spot then, dies and falls and other leaves die. Usually called August "Rust.', Spray 3 pounds dry lime sulfur to 100 gallons water; or one pound potassium sulphide to 32 gals. water. Get Farm Bulletin No. 416, Washington.

DRY LIME-SULFUR-For San Jose Scale-Price, 1.lb.

at $30 \mathrm{c} ; 10 \mathrm{lbs}$. at $28 \mathrm{c} ; 25 \mathrm{lbs}$. at $25 \mathrm{c} ; 100 \mathrm{lbs}$. at $20 \mathrm{c}$ per lb. Mix $8 \mathrm{lbs}$. to $50 \mathrm{gal}$. of water.

COLD IIME-SULFUR WASH (Solution)-For San Jose Scale. 1 gal. $80 \mathrm{c}$; $1 / 2$ bbl. ( 30 gal.) at $32 \mathrm{c}$ gal.; bbl (50 gal.) at $30 \mathrm{c}$ gal. Mix 1 gal. to 8 of water.

PASTE ARSENATE OF IEAD-For leaf-eating insects. $4 \mathrm{lbs}$. to 50 gals water. Price, $1 \mathrm{lb}$. $40 \mathrm{c}$; $5 \mathrm{lbs}$. at $30 \mathrm{c}$ $25 \mathrm{lbs}$, at $25 \mathrm{c} 1 \mathrm{~b}$.

DRY ARSENATE OF LEAD-2 lbs, to 50 gals. water. Price, $1 \mathrm{lb}$. $50 \mathrm{c} ; 5$ lbs. at $45 \mathrm{c} ; 25 \mathrm{lbs}$. at $40 \mathrm{c} ; 100 \mathrm{lbs}$. at $35 \mathrm{c}$ per $1 \mathrm{~b}$.
ARSENATE OF IIME-Made especially for Cotton Leaf Worm and tender garden foliage. For cotton, dust $5 \mathrm{lbs}$. per acre on dew-wet plants (see Monarch Duster, $\$ 15.00$ ), or spray 4 lbs. to 50 gals. of water. $5 \mathrm{lbs}$. at $48 \mathrm{c} ; 25 \mathrm{lbs}$ at $39 \mathrm{c} ; 100 \mathrm{lbs}$. at $37 \mathrm{c} \mathrm{lb}$.

B. T. S.-Sulfur and Barium. Use same as Dry LimeSulfur. Use $8 \mathrm{lbs}$. to 50 gals. water. Price, 5 lbs. at $25 \mathrm{c} ; 10 \mathrm{lbs}$. at $20 \mathrm{c} ; 25 \mathrm{lbs}$. at $16 \mathrm{c} ; 50 \mathrm{lbs}$. at $15 \mathrm{c} \mathrm{lb}$.

"INSECTO," or DRY BORDEAUX MIXTURE-For fungus rots, blight, mildew and melon anthracnose and stem-end rot, etc. Use 8 lbs. to 50 gals water. Price, $1 \mathrm{lb}$. at $45 \mathrm{c}$; $5 \mathrm{lbs}$. at $40 \mathrm{c} ; 25 \mathrm{lbs}$. at $35 \mathrm{c} ; 50 \mathrm{lbs}$. at $33 \mathrm{c} \mathrm{lb}$. ATOMIC SULPHUR-For Brown Rot-Price, 5 lbs. at $20 \mathrm{c} ; 25 \mathrm{lbs}$. at $16 \mathrm{c} \mathrm{lb}$; $100 \mathrm{lbs}$. at $13 \mathrm{c} \mathrm{lb}$.

FLOUR SULFUR-(Best grade.) $10 \mathrm{lbs}$. at 15c lb.; 100 lbs. at $12 \mathrm{c} \mathrm{lb}$

FRESH LIME-1 barrel, $\$ 2.75$.

CALCIUM ARSENATE POWDER-The U. S. Gov. remdy for control of Mexican boll weevil. Dust (Use "Monarch" Hand Duster, \$15.00), 5 lbs. per acre. "Contains 42 per cent Ars. oxide-(Ars. Lead has 32 per cent and Paris Green 55 per cent) - and is the cheapest arsenical poison. Use also about 2 lbs. per acre dust, or 2 lbs. per 50 gals. water-for potato bugs, tobacco horn worm, coddling moths, Gypsy and brown-tail moths. Do not use on very tender or on stone fruit foliage. Price, $25 \mathrm{lbs}$. at $33 \mathrm{c}$; $50 \mathrm{lbs}$. at $32 \mathrm{c} ; 100 \mathrm{lbs}$. at $30 \mathrm{c}$ per $1 \mathrm{~b}$.

ANIMAL PARASITE KILLER-About two and one-half times stronger than carbolic acid. Mix 1 part to 25 of water. Kills fleas, lice, mites, itch and mange. One pint, $30 \mathrm{c} ; 1$ quart, 50c; 1 gallon, $\$ 1.25 ; 5$ gallons, $\$ 1.00,10$ gallons, $85 \mathrm{c}$ gallon, cans extra.

SUN SANITARY FUUID-Much stronger than carbolic acid. Mix 1 part to 50 of water. An ideal disinfectant, deodorizer and antiseptic for dwellings, stables, poultry houses, etc. One pint 20c; 1 quart $35 \mathrm{c} ; 1$ gallon $\$ 1.00$. 5 to 10 gallons at $85 \mathrm{c}$ per gallon, can extra; one barrel at $75 \mathrm{c}$ per gallon.

RUTHLESS INSECT EXTERMINATOR-For mosquitoes, dog fleas, Argentine ants, flies, etc. (Use No, 2 heavier-bodied for cattle fly spraying.) Prices: (Spraying machines are sent free with each package below.) Pts. 40c qts. $60 \mathrm{c} ; 1$ gal. $\$ 1.60 ; 10$ gals. $\$ 1.50$ a gal.; $1 / 2$ bbl. $\$ 1.35$ per gallon.

HOUSEHOLD CLEANSING FLUID-Removes spots, grease, oil, fats. varnish, paints. Harmless to fabric or colors. Odorless and non-inflammable-better than benine. Price, $1 \mathrm{lb}$. tin $50 \mathrm{c}$; postpaid $60 \mathrm{c} ; 5 \mathrm{lb}$. tin $\$ 1.75$.

PARIS GREEN-Wet Method: One pound to 100 gals. water; dry method, 1 pound to 100 pounds of flour. $1 / 2 \mathrm{lb}$. $40 \mathrm{c} ; 1$ lb. 60c; 2 lbs. for $\$ 1.00$.

"BLACK LEAF 40 ', - A contact poison for sucking insects, plant lice and young bugs that attack cabbage and collards, cucumbers and melons for leaf hoppers, aphides and thrips, and all soft-bodied sucking insects. Use teaspoonful to $1 / 2$ gal. water in small amounts. A better spray is made by dissolving soap, and then adding "Black Leaf $40^{\prime}$ ' in order to produce suds. One ounce bottle (makes 6 gals.), 25c; 1/2 lb. (for 50 gals.), $75 \mathrm{c} ; 2 \mathrm{lbs}$. (for 200 gals.), $\$ 2.50$.

WHATE OIL SOAP-Lice and delicate larvae, 1 pound to 5 gallons of water. For White Flies, use $1 \frac{1 / 2}{\text { ounces of }}$ Whale Oil Soap per gallon of water and spray. Prices: $1 \mathrm{lb} .25 \mathrm{c} ; 5 \mathrm{lbs}, 20 \mathrm{c} ; 25$ to $50 \mathrm{lbs}$. $15 \mathrm{c} ; 100 \mathrm{lbs}$. $14 \mathrm{c} \mathrm{lb}$ KEROSENE EMULSION-A remedy against soft-bodied and sucking insects, such as plant lice, leaf aphis, squash bug, mealy bug, cabbage worms, etc. Make solution on part to twenty of water. One quart $80 \mathrm{c} ; 1$ gallon $\$ 1.50$.

LEMON OIL-Mix one tablespoonful with two cups of warm water. Apply sprayer or sponge. Destroys mealy bugs, scale, red spider, also mildew on plants, vines, hedges, etc. $1 / 2$ pint $25 c ; 1$ pint $40 c ; 1$ quart $75 c ; 1 / 2$ gallon $\$ 1.25$; 1 gallon $\$ 2.00$

SULPHO TOBACCO SOAP-For spraying flowers, vines, shrubs, vegetables, etc., for insects, such as red spiders, and for lice and sucking insects, two ounces makes gallon solution. 3-0z. cake, $10 \mathrm{c} ; 8-0 z$. cake $20 \mathrm{c} ; 10$-1b. cake $\$ 3.00$.

BISULPHIDE OF CARBON-For weevils and insects in grain to be stored away. Use in corn crib, in keeping corn, 1 pound to 70 bushels of corn, or 500 cubic fee space. Used to fumigate planting cotton seed-killing boll weevil. Put liquid in a vessel on top of material for fumigation; close room tight 24 hours; keep all fire away (fumes explosive). Pour teaspoonful in hole of any bur. rowing animal and cover hole with earth and it will kill it. Price: One lb. can 60c; 5-1b. cans $\$ 2.75$.

HAMMOND'S SLUG SHOT-(Arsenic, carbolic acid, tobacco, lime and sulphur-insecticide and fungicide.) Nonpoisonous to animal. For all biting and chewing insects, cabbage worm, cut worm (dust the roots), potato bug larvae, hairy caterpillar, sour bug, hard shell wood lice, etc. For the florist a, fine harmless fungicide and insecticide. Dust on dew wet plants, or spray liquid 5 pounds
to 50 gallons water. Price: 1 lb. $20 \mathrm{c} ; 5$ lbs. $50 \mathrm{c} ; 10 \mathrm{lbs}$. for $\$ 1.00$. Parcel Post extra. 
BUG DEATH-Read "Slug Shot" notes above and use for same purposes and similarly. Price: $1 \mathrm{lb}$. with per-

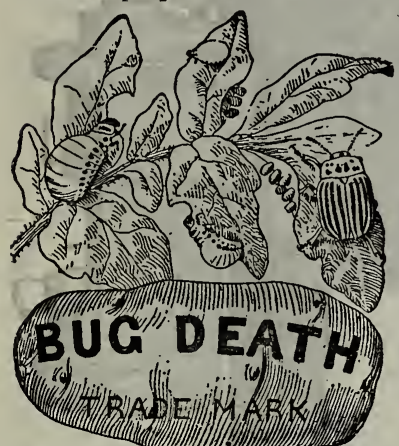
forated metal top $20 \mathrm{c}$; lbs. $45 \mathrm{c} ; 5 \mathrm{lbs} .60 \mathrm{c} ; 12 \frac{1 / 2}{2}$ lbs. $\$ 1.35$. Express or postage extra. Can be sent by parcel post.
FORMALIN (formal ehyde) 65c per pint. BLUE STONE 1 ib. $30 \mathrm{c} ; 5$ lbs. at $25 \mathrm{c}$ lb. For wheat, prevents smut, one ounce to $11 / 2$ gallons of water, soak 12 hours.

TOBACCO DUST AND STEMS-Cne lb. $15 \mathrm{c}$; lbs. at $14 \mathrm{c} ; 25$ lbs. a $12 \mathrm{c} ; 100 \mathrm{lbs}$. at $9 \mathrm{c}$. TICIDE-For white fly, scale, mealy bugs, rust scale, mealy bugs, rust
mite and red spider. Ap. mite and red spider. Apply 1 gallon Schnarr to Price: 1 gal. $\$ 1.50 ; 5$ gals. $\$ 6.00 ; 10$ gals.

Pat. in Canada Nov, 2,1897 and Jan. 2 ;, 1900 $\$ 10.00$.

Use for Slug Shot or Bug Death. Each.

Use for Slug Shot or Bug Death on larger scale. Each $75 \mathrm{c}$

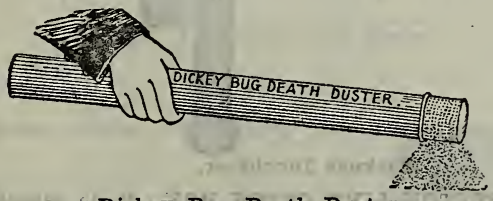

Dickey Bug Death Duster.

COOPER'S FLUID-Disinfectant; germicide-Cows, hogs, sheep, horses, dogs. For hog lice, etc., spray one tablespoonful to one pint water. For mange, ringworm, eczema, wash parts three times a day, one tablespoonful fluid to one pint water. Wounds and sores, bathe solution, two one pint water. Wounds and sores, bathe solution, two tablespoonfuls to five pints water. For sheep scab, ollt
gallon to 120 gallons water-two dippings. Price: One-half gallon to 120 gallons water-two dippings. Price: $O$
pint, $25 \mathrm{c}$; quart $75 \mathrm{c} ; 1 / 2$ gal. $\$ 1.25 ; 1$ gallon $\$ 2.00$. pint, $25 \mathrm{c}$; quart $75 \mathrm{c} ; 1 / 2$ gal. $\$ 1.25 ; 1$ gallon $\$ 2.00$.
COOPER'S CATTLE DIP TO DESTROY THE CATTLE TICK-Texas Fever Ticks can be absolutely eradicated by dipping or spraying with Cooper's Cattle Dip. Is a concentrated liquid immediately mixable - with cold water centrated liquid immediately mixable with cold water lution. Has official recognition for U. S. Dept. of Agricullution. Has official r
ture for official work.

Equally Effective for Dipping or Spraying.

The small cattleman only needs a spray pump. No expensive apparatus necessary-no cooking or danger. Safest cattle dip for the small or large operator. A gallon or cattle dip for the small or large operator. A gallon or 100 gallons can be mixed as wauted. Keeps indefinitely. Is efficient; doesn't scald or injure hide; has be

by many governments throughout the world.

$$
\text { Dangerous to Use Home-Made Dips. }
$$

While coal tar and like dips are worthless for destroying ticks and money paid for them thrown away, there is much danger attending the making of arsenic dips. Arsenic is a poison and unless handled scientifically may couse is a poiso.

\section{Incubators, Brooders}

WE ARE AGENTS FOR THE BUCKEYE INCUBATORS AND BROODERS.

We haven't sufficient space to give full description of all Incubators and Brooders that this company manufactures, but will be glad to send you one of their complete descriptive catalogs upnn request.

BUCKEYE INCUBATORS-These Incubators are all guaranteed by the manufacturer and each machine carries the- following guarantee:

GUARANTEE-The Buckeye is graranteed to hatch more chicks and stronger chicks than any other Incubator.

It Is Furtzer Guaranteed-To require no artificial mois ture. To operate satisfactorily in any temperature down to freezing and to require no attention to the regulation from the time a hatch is started until it is finished.

The perfect construction of all its mechanical parts is also guaranteed and any Incubator or part thereof that does also guaranteed and any Incubator or part thereof that does without question any time within forty days. (Signed)

Each machine carries the underwriter's label which shows it to be fireproof and approved by the National Board of Fire Underwriters. The Buckeye Incubator Co manufacture two grades of Incubators; one a medium price machine, and the other the highest class that can
Price of Cooper's Cattle Dip-One quart, $\$ 1.25$ (makes 38 gallons); $1 / 2$ gallon, $\$ 1.75 ; 1$ gallon, $\$ 3.00$ (makes 155 gallons).

\section{SPRAY IMACHINES.}

We are sole Augusta agents for the H. L. Hurst Mfg. Co. (Ohio) Spray Machines. Get large catalog-Machines, Plant Diseases and materials.

Hurst's Fitz-all No. $1 \mathrm{~A}$ with bbl., $18 \mathrm{ft}$. hose, $2 \frac{1}{2}$-inch cylinder for two men. Price, $\$ 30.50$.

Hurst's Fitz-all No. 7, with bbl., $2 \frac{1}{2}$-inch cylinder, $18 \mathrm{ft}$. hose and 10 gal. galv. iron compression tank for one man. Price, $\$ 36.70$.

Hurst's Man Power No. 3, 10 gal. with wheel; wide spray. Price, $\$ 37.50$

Hurst's Bucket Pump, galv. iron No. 9. Price, $\$ 5.00$.

Hurst's Bucket Spray, brass, No. 8. Price, $\$ 8.00$.

Hurst's Aero mist compressed air sprayer with shoulder straps; galv, iron No. $10 \mathrm{D}$. Price, $\$ 6.65$.

DEMING'S No. 6591/2-Used largely for spraying cattit. "Veterinary Success" Sprayer.

Complete, with 10-ft. lead and nozzle.............\$7.00 LOWELL'S FOUNTAIN COMPRESSED AIR SPRAYER

No, 110-The latest and most improved sprayer for small orchards, gardens and truckers. Price........................ $\$ 7.00$

LOWELL'S BUSINESS SPRAYER No. 123-Continuous compressed air with shut-off; galvanized steel.

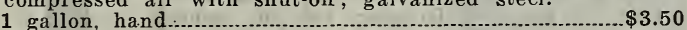
AUTO SPRAY PUMPS- "Brown's Knapsack." The best knapsack compressed air sprayer known. Convenient and easy to operate.

Galv. Iron, 1D, each...............\$ 7.50 Brass, each, 1B...... 11.00 SPRAYER MACHINE No. 662Deeming's "Universal," "the only small spray pump we know that can be used successfully for both spraying and whitewashing. Six pumps in one.

Price, Galvanized Iron, com-

plete -.................................. 130

Price, Brass, complete........... 17.00 THE STANDARD SPRAY PUMP - For small orchards, truck or to use as a bucket pump; has no equal. Price, complete with hose.........\$5.00 HAND SPRAYERS. Every one knows the use of a brayer, and no home should be without one. We hand sprayer, and no home should be without one. We
earry a complete line-one of the best assortments we can possibly find.

Hudson No. 4512 Hand Sprayer, 1 quart..................\$0.60 Lowell's No. 101 Glass Tank Hand Sprayer, 1 quart .85 -This Sprayer has a glass tank that is easy to remove and clean, and any kind of liquid can be used and no dam.

age to the tank. The best hand sprayer known. 1 quart

Lowell's No. 108 Dust Blower. Eeach..................... $\$ 1.00$ Nothing is better for spraying lice powders and dry insecticides.

MONARCH DUSTER-Hand power. The Government says is the best for dusting Mexican Boll Weevil (Coad process), cotton leaf worm, Irish potatoes, melons and all vegetables. Price, $\$ 15.00$.

\section{and Poultry Supplies}

possibly be manufactured. We carry a complete stock of each of these machines.

Buckøye No. 14, Style E-65 egg capacity, each....\$10.50 Buckeye No. 15, Style H-65 egg capacity, each... 14.50 Buckeye No. 16, Style E-120 egg capacity, each ... 18.50 BUCKEYE INCUBATOR STANDARD HIGH PRICE.
BUCK

Buckeye Standard No. 60,65 egg capacity, each....\$17.50 Buckeye Standard No. 1, 120 egg capacity, each.... 24.50 Buckeye Standard No. 2, 175 egg capacity, each.... 29.50 Buckeye Standard No. 3, 250 egg capacity, each.... 39.50 Buckeye Standard No. 4, 350 egg capacity, each....47.50 Buckeye Standard No. 5, 600 egg capacity, each.... 70.00 The Buckeye Incubator Company also manufacture MAM. MOTH INCUBATORS capacity $2,440 \mathrm{eggs}$. If interested in this machine, would bs pleased to quote special price delivered, shipped direct from the manufacturer.

BUCKEYE BROODERS-Brooders as manufactured by the Buckeye-people carry a guarantee, and you will find the following on each machine

Guaranteed to raise more chicks and bigger chicks than any other Brooder.

Guaranteed to furnish an abundance of heat in any temperature down to freezing. 
Guaranteed to be absolutely free from all gases or odors and to provide a circulation of pure, fresh air every minute in the day. Sold on Thirty Days' Approval-and if not satisfactory you can get your money ack

BUCKEYE OIL BURNER BROODERSThese are the best oil burner Brooders made today, well built and so constructed that chicks never crowd. This feature is lacking be a failure.

BUCKEYE PORTABLE BROODERS.

No. 20 , capacity 60 chicks

No. 21 , capacity 100 chicks

No. 22, capacity 150 chick SECURITY, capacity 150 chicks......... 12.50 BUCKEYE COAL BURNING BROODERS -This is the latest in Brooders that will take care of a large number of chicks. These are guaranteed the same as other Brooders listed above.

STANDARD No. 18 , capacity any num-

ber up to 500 chicks, each............
STANDARD No. 19 , capacity any num-

ber up to 1,000 chicks, each

$\$ 17.50$

BU up 21.50 est Colony House ever built or offered. It makes an ideal Brooder House equipped with a Buckeye Portable Brooder, size 60 inches long, 36 inches wide and 36 inches high. Complete with floor, etc., $\$ 12.50$ each, f. o. b. factory.

POULTRY NETTING-(50 $\mathrm{yds}$. to roll.) Used for fencing houses, chick runs, and many other things about the farm. We handle only the Best Grade.

1 ft. 2-inch mesh............................. $\$ 1.50$

2 ft. 2 -inch mesh

3 ft. 2 -inch mesh

4 ft. 2-inch mesh 2.60
3.50 3.50
4.50

5 ft. 2 -inch mesh

6 ft. 2 -inch mesh........ 6.50

$1 \mathrm{ft}$. 1 -inch mesh.........\$3.25

2 ft. 1-inch mesh

4 ft. 1-inch mesh. we will be glad to give you a special price. UNION POULTRY LOCK FENCING-Union Lock is the standard poultry fence of the day, making not only one of the neatest, but the strongest and cheapest fence that can

e built. Price per roll of ten rods, or 165 feet-

ft. high, $165 \mathrm{ft}$. long $\$ 2.75 \quad 4 \mathrm{ft}$. high, $165 \mathrm{ft}$. long $\$ 4.00$ ft. high, $165 \mathrm{ft}$. long $3.10 \quad 5 \mathrm{ft}$. high, $165 \mathrm{ft}$. long 4.50

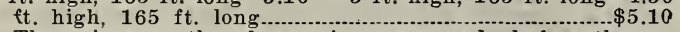

The prices on the above wire were made before the retent advance, but we will not change our prices until what stock we have on hand is sold.

THE BLACK HAWK GRIST MILI_Price............... $\$ 3.50$ THE BLACK HAWK CORN SHELLER-Price............ 3.00 EMPIRE TRAINING AND EXHIBITION COOPS.

We are agents for the Empire Cooping Company, and can furnish any coops listed by them. We carry a full line in stock. Write for their catalog, giving full descriptions. Prices, f. "o. b. Augusta.

Style AA-One apartment cage, wire front, top and back. Solid veneered ends. Length $2 \mathrm{ft}$., width $2 \mathrm{ft}$., height 27 in. Each, \$4.00.

Style C-Standard two-apartment poultry coops with wire front, top and back. Solid 3-ply veneered ends and partitions, or wire ends and partitions. Length of section $4 \mathrm{ft}$. Size of apartments $22 \times 24 \times 27$ in. Each, $\$ 6.00$.

Style A-Standard 3-apartment poultry coop with wire front, top and back. Solid veneered ends and partitions. Length of section $5 \mathrm{ft}$. 6 in. Size of apartment $22 \times 24 \times 27$ in. Each, $\$ 6.50$

Style B-Standard 3-apartment poultry coop, with wire front and top. Solid 3-ply veneered back, ends and partitions. Length of section $5 \mathrm{ft}$. 6 in. Size of apartment $22 \times 24 \times 27$ in. Each, $\$ 7.00$.

Style $H-P \in n$ Exhibition Coop, with veneered or wire cnds. Earh, $\$ 6.00$

With solid 3-ply veneered back. Each, \$6.50.

Length of pen $4 \mathrm{ft}$., width 30 in., height 30 in.

Style E-Standard 4-apartment Bantam or Pigeon coop, with wire front, top and back. Solid 3-ply veneered ends and partitions. Length of section $6 \mathrm{ft}$. Size of apartments $18 \times 18 \times 18$ in. Each, $\$ 7.00$.

ERIE SHIPPING COOPS-This coop is especially adapted for use in shipping fancy fowls. The tops and bottoms are made of wood. The body is made from extra heavy cor. rugated paper, which protects the fowls from draughts and from heat or cold. Each Doz.

Erie No. A, $12 \times 16 \times 17$ Each Doz.

Erie No. B, $12 \times 18 \times 22$ $\$ 6.30$
7.15

Erie No. C, $12 \times 22 \times 22$
Erie No. D, $20 \times 22 \times 22$

Erie No. E, $20 \times 24 \times 22$

1.20
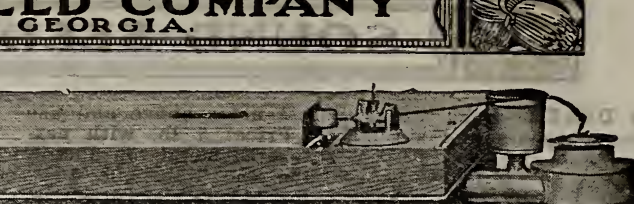

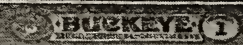
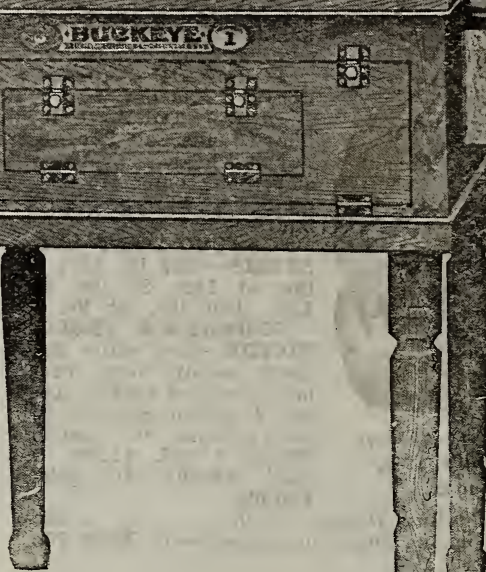

Buckeye Incubator.

THE SEFTON LIVE CHICK BOX-Made especially for shipping live chicks. Amount saved in express will alone pay for boxes. Each Doz.

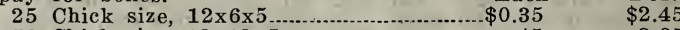

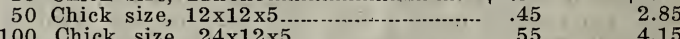

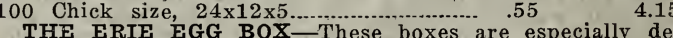
THE ERIE EGG BOX-These boxes are especially designed for shipping settine is protected upon all sides with one thickness of corrugated paper. When the top is on and the handle is inserted it locks the box so there can be no substitution of

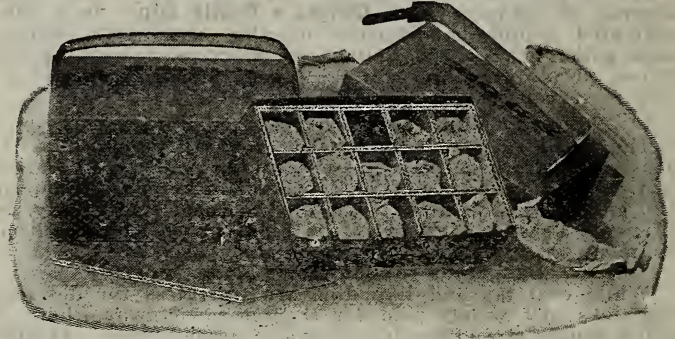

Erie Egg Box.

inferior eggs. The handle serves its purpose in carrying the package and also the expressmen are not liable to drop everything on a box with-a veneer handle, as it is a re-

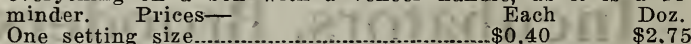
One setting size........................................ \$0.40 $\$ 2.75$ Two setting size.................................. packıng eggs for setting purposes in quantity. PricesFolded flat for shipment: 50 -egg size, each $55 \mathrm{c}$; dozen, $\$ 4.15 ; 100-\mathrm{egg}$ size, each $80 \mathrm{c}$; dozen, $\$ 6.65$.

PAPER EGG BOXES FOR MARKET EGGS-Dozen, 35c $100, \$ 1.25 ; 1,000, \$ 9.00$.

We can furnish these printed in any style customers may wish at $50 \mathrm{c}$ per 1,000 additional.

FARMERS' MODERN FGG CARRIERS-Holds $12 \mathrm{doz}$ en. No breaking. Especially constructed for handling market eggs.

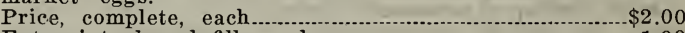

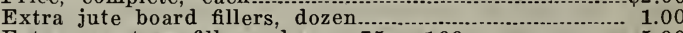

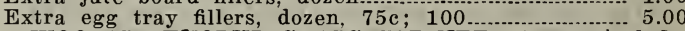

WOOD'S REVOLVING EGG CABINET-A practical de vice for taking care of and turning eggs that are kept for hatching purposes.

150-egg size, weight 30 lbs., each.............................. $\$ 4.00$ 288 -egg size, weight 55 lbs, each..................................... 6.00 560 -egg size, weight 75 lbs., each

KNOX LICE EXPELLING NEST EGGS A Lice Killer and Nest Egg combined in one. These are effective, lasting, not expensive, and superior to others in form, size and 
appearance. They look exactly like natural eggs. Price, each $10 \mathrm{c}$; dozen $75 \mathrm{c}$

CHINA NEST EGGS-The most ideal china nest egg known Price, each $5 \mathrm{c}$; dozen $35 \mathrm{c}$

CORNELI'S TRAP NEST-This is positively the only means by which a laying strain can be attained. When made made practicable they are not as inconvenient as one would
at first suppose. This is one of the best nests on the market today, strongly built and will last with proper care indefinitely. Price, each, $\$ 2.00$

IEG BANDS-Why are leg bands used? We are often asked this question. Every breeder of note is today using them. Different individuals and strains are kept separate in

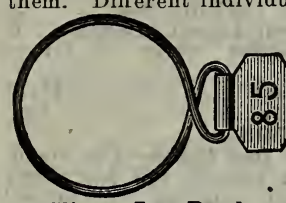
this way. Poultrymen exhibiting birds are Poultrymen exhibiting in order that judges will have (D) some method of identifying indiI. vidual birds on score cards. The age of birds, too, can be kept able should be disposed of. You have to band in order to keep Climax Ieg Band. correct egg records. There should be more bands used. We carry a complete line. In ordering Leg. Bands always give sizes wanted or name of breed of fowls and number of males and females.

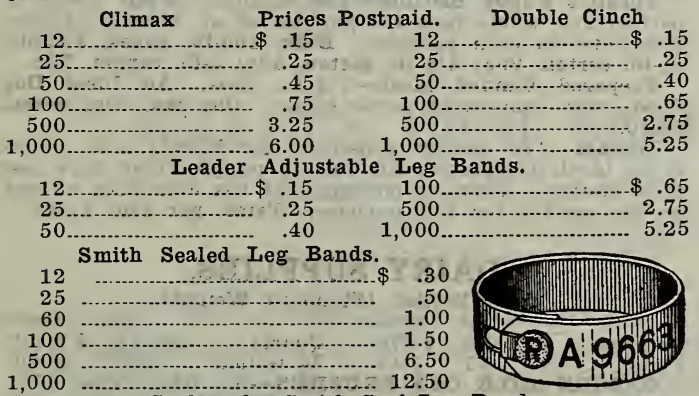
$1,000 \quad$ Sealers for Smith Seal Leg Bands. $\$ .65$

Plain, each
Open Pigeon Leg Bands-Bantams and Pigeons. \begin{tabular}{c}
12 Open Pigeon Leg Bands-Bantams and Pigeons, $\$ .65$ \\
\hline 15
\end{tabular}

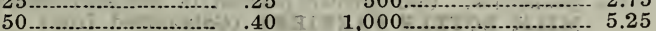
Pilling's French Poultry Killing Knives-Price, postpaid, $50 \mathrm{c}$.

Poultry Markers-You should keep a record of your birds, mark them as soon as hatched; the different dates of hatches, etc., should be kept. We carry several makes of the best.

Model Poultry Marker-Each.

Lambert's Marker-Each

Petty's Marker-Each PILLINE - PHILA.

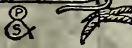
Judging Sticks-Prices, small, $65 \mathrm{c}$; medium, 85c; large, $\$ 1.00$. Pilling Fow

CAPONIZING INSTRUMENTS-We carry in stock a complete line of Caponizing Instruments and Poultry Surgical Cases. Write us for literature if interested.

Pilling's, Philadelphia Caponizing Sets, complete with instructions, $\$ 2.50$.

Pilling's Farmer Caponizing Sets, complete with instructions, $\$ 3.00$.

Pilling's Cupped Forcep Caponizing Sets, complete with instructions. $\$ 5.00$.

Farmer Miles' Caponizing Sets, complete with instructions, $\$ 7.50$.

Pilling's Poultry Surgical Cases-Pilling's Poultry Sur-

gical Case No. $15, \$ 1.50$.

Pilling's Poultry Medical and Surgical Case No. 30, $\$ 3.00$. Pilling's Poultry Medical and Surgical Case No. 50, $\$ 5.00$. Pilling's Poultry Medical and Surgical Case No. 75, $\$ 7.50$. FOOD HOPPERS-Different style food hoppers are made according to different methods of feeding, and are practical and often save their cost in feed bills the first month. We carry a complete line of all standard tested kinds.

COAT'S AUTOMATIC POULTRY EXERCISER AND FEEDER-IT IS THREE MACHINES IN ONE-Three sets of different size wire mesh accompanying each feeder. It takes but a minute to change it to a grain feeder. Changing the mesh does the trick. These feeders are guaran teed by the manufacturer to give satisfaction. PRICE:

No. 1 holds 6 quarts, $\$ 1.25$, for little Chicks.

No. 2 holds 8 quarts, $\$ 2.00$, for Hens.

No. 3 holds 12 quarts, $\$ 3.00$, for Hens.

No. 4 holds 20 quarts, $\$ 3.50$, for Hens.

NORWICH AUTOMATIC FEEDERS-This is one of the best Automatic Grain Feeders on the market. It can be kept out of doors at all times and will last a lifetime. Price: No. $1-1$ peck............. $\$ 2.50$ No. $3-1$ bushel........... $\$ 4.10$
SIX IN ONE EXERCISER AND FEEDER-The Six in fered on the market. It has a large compartment in the center for mixed grain, which is fed automatically. $\mathrm{Be}$ sides this it has five other compartments for dry mash, oys ter shell, grit and charcoal. They are all intact, ready, and is the only Feeder known on the market today that the is the only Feeder. known on the market today that the his flock will be properly fed and systematically during his absence. They are strongly built and with care will last forever. We advise all poultry raisers to at least try one of these. 20-quart size, each, $\$ 3,75$.

MODEL DRY FOOD HOPPERS-Made of heavy galvan ized iron and should with little care last a lifetime. Suit able for Dry Grain and Beef Scraps. Price, each, $\$ 1.00$; $1 / 2$ dozen, $\$ 5.00$.

FAVORITE DRY FOOD HOPPERS-Rust-proof and will never clog. Has round bottom made of heavy galvanized iron. The best wall dry mash Food Hopper known.

12-in., each..\$1.25 18-in., each..\$1.50 24-in., each..\$1.75

FAVORITE CHICK FEEDERS-This is the only prac tical dry mash wall chick feeder that we have ever offered. These are well made and are very. handy to use in a Brooder house. 10-inch, each ..........................75c

MODEL GRIT AND SHELL BOX No poultryman can be without heavy galvanized iron and will last a lifetime. The top keeps contents clean and protects from rain. Made especially for holding. Oyster Shell, Grit, Charcoal, Bone, etc. and can be hung on side of walls of pen, keeping these necessities constantly before your birds. Price each, $75 \mathrm{c} ; 1 / 2$ dozen THE OVERALL FEEDER-Thi is one of the best Feeders on the market today, especially for feeding mash feeds. There is no waste of feed, and they are easily accessible. There is no clogging of feed, and can be cleaned without waste of time. This feeder is
strong and will last a lifetime with strong and will last a lifetime with
any care. Price:

Chick size $\$ 0.55$

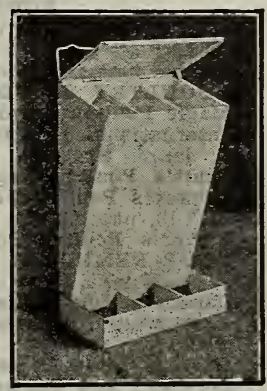

Model Grit and Shell

Boxes.
Six-quart size

DRINKING FOUNTS-Every poultryman knows the necessity of keeping before his birds at all times fresh clean water; for results your birds will require this. We carry a complete line of drinking founts, all sizes and suitable for any conditions.

HALLOCK FOOD AND WATER HOLDERS-Excellent to feed wet mash feed or suitable to water ducks or any fowl. Wires protect food and birds can not get in pan and soil feed or water. The holder can be carried about with perfect safety, as the greater the weight the tighter the grip of the wires. Price-1-gallon size, each, $\$ 1.00$; one-half dozen, $\$ 5.00$.

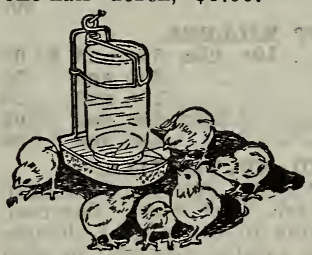

DAVIS FOOD AND WATER FOUNTAINS-A very cheap and practical fount or feed a water fount or a fruit jar as a feed hopper. Hangs against the wall in brooder houses. Little chicks can easily drink, yet do not get wet. Each, 25c; $1 / 2$ dozen, $\$ 1.25 ; 1$ dozen, $\$ 2.25$. MODEL DRINK FOUNTSof heavy galvanized iron and will not rust or freeze. Made in several sizes suitable for baby chicks or grown birds. 1 qt. size, 30c; $1 / 2$ doz., $\$ 1.50 ; 2$ qt. size, $35 \mathrm{c} ; 1 / 2$ doz. $\$ 1.80$ 3 qt. size, $40 \mathrm{c} ; 1 / 2$ doz. $\$ 2.20 ; 4$ qt. size, $50 \mathrm{c} ; 1 / 2$ doz. $\$ 2.75$ Sanitary Stone Drinking Founts - Made in sizes suitable for baby chicks or grown birds, easy to clean and especially fine for summer use keeping water fresh and cool

1 qt. size, each $30 \mathrm{c} ; 1 / 2 \mathrm{dz}$., $\$ 1.50$ 2 qt. size, each $35 \mathrm{c} ; 1 / 2$ dz., $\$ 1.80$ 4 qt. size, each $50 \mathrm{c} ; 1 / 2 \mathrm{dz}$., $\$ 2.75$

Model wall Founts (Square and Round Bottom) - This fount is very handy and can be rung on wall a few feet above the floor in the houses, pens, or yards, and keeps birds from getting dirt in them yet enables the birds in them, yet enables the birds Made of galvanized iron and guarMade of galvanized iron and guar-

Gallon size, each $75 \mathrm{c} ; 1 / 2$ dozen, Model Drink Founts.
$\$ 4.00 ; 2$ gallon size, each, $\$ 1.00 ; 1 / 2$ dozen, $\$ 5.00$.

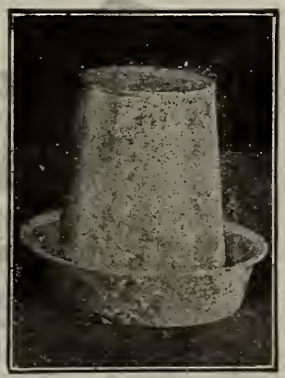


FEED AND WATER CUPSThese are especially adapted to use in exhibition or conditioning coops. Single size, each, $15 c ; 1 / 2$ dozen $75 c$; 1 dozen $\$ 1.35$. Pen size, each 20c; $1 / 2$ dozen $\$ 1.20 ; 1$ dozen $\$ 2.00$.

BEISE DRINKING FOUNTS-One of the best founts, made of galvanized iron and nicely finished. Fills same as a pail, does not spill when laid down for use and the convex front prevents bursting in winter also makes it easy to clean. No. 1 holds 3 qts., Little Chicks, $45 \mathrm{c}$; No. 2 holds 2 gals., Grown Fowls, $75 \mathrm{c}$; No. 3 holds 3 gals., gals. Grown Fowls, 95c.

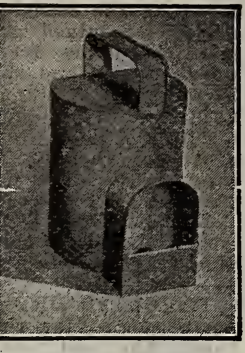

Model Wall Founts. gals., Grown Fowls, 95c.

is a small fount, handy and easy to clean. Nothing better to use for young chicks in brooder houses, or for an old hen in brood coop. Do not break easily, and last indef initely. Each, $15 \mathrm{c} ; 1 / 2$ dozen, $75 \mathrm{c} ; 1$ dozen, $\$ 1.25$.

\section{POULTRY REMEDIES.}

All remedies listed below we have handled for a number of years; all are reliable. For some we are agents. Any listed we can recommend.

POULTRY POWDERS AND EGG PRODUCERS.

Magic Poultry Powder, small size, 25c; large size, 50c.

International Poultry Powder, small size, $25 \mathrm{c}$; medium, $50 \mathrm{c}$; large, $\$ 1.00$

Pratt's Poultry Regulator, $15 \mathrm{c}, 30 \mathrm{c}, 60 \mathrm{c}, \$ 1.20$.

Conkey's Poultry Tonic, $1 \frac{1}{2}-\mathrm{lb}$. pkg., 25c; $31 / 4-1 \mathrm{~b}$. pkg.,

$50 \mathrm{c} ; 7-1 \mathrm{~b}$. pkg., $\$ 1.00$.

Saylor's Poultry Powder, 25c.

ROUP REMEDIES-Conkey's Roup Remedy, small size,

$25 \mathrm{c}$; medium, 50c; large size, $\$ 1.00$.

Conkey's Roup Pills-25c and $50 \mathrm{c}$.

Rust Roup Pills-Small size, 25c; medium, 50c; large, $\$ 1.00$.

Willet's Roup Remedy-Small size, 25c; large, 50c.

Sorehead and Chicken Pox Remedies-Conkey's Chicken

Pox Remedy-Small size, 25c; large, $50 \mathrm{c}$

Conkey's Healing Ointment-25c.

Southern Wonder-\$1.00.

White Diarrkoea Remedies-Conkey's $25 \mathrm{c}$ and $50 \mathrm{c}$.

Cholera Remedies-Conkey's Cholera Remedy, small size, $25 \mathrm{c}$; large, $50 \mathrm{c}$.

Willet's Cholera Remedy-Small size, 25c; large, 50c. MISCELLANEOUS POULTRY REMEDIES.

Conkey's Scaly Leg Remedy.

Conkey's Worm Powder

Conkey's Gape 'Remedy

Conkey's Limber Neck Remedy

$25 \mathrm{c}$ and $50 \mathrm{c}$

Conkey's Rheumatic Remedy.............................................

Conkey's Canker Remedy.................................................50

Conkey's Flea Salve.......
Oculum

\section{LICE AND INSECT KILLERS.}

Lambert's Death to Lice...............10c, 25c,50c and $\$ 1.00$

Conkey's Insect Powder.

Conkey's Head Lice Ointment

Conkey's Lice Liquid..

Conkey's Noxicide $\begin{array}{rr}25 \mathrm{c} \text { and } & .50 \\ .10 \mathrm{c} \text { and } & .25\end{array}$ $35 \mathrm{c}$ and .60

We POULTRY FEEDS AND NECESSITIES.

We carry a complete line of Poultry Feeds and Necessi ties, such as: Scratch Feed, Mash, Beef Scrap, Charcoal, Grit, Oyster Shell, etc. But owing to the market changes we are unable to quote prices in catalog, but will be glad to do so on request.

\section{DOG FOODS AND REIMEDIES.}

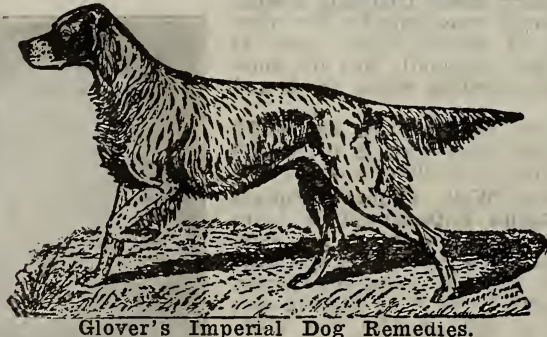

Distemper Remedy........\$1.00

Mange Remedy ........... $\quad .50$

Vermifuge

$\$ 0.50$

Black Tongue Remedy .50

Liver Pill

Condition Pills

Liniment

50 Digestive Pills

Diarrhoea Remedy
We carry a full line of the above remedies, which are known by all dog owners. If interested, write for Dr.

Glover's book on dog diseases-free.
SERGEANT'S DOG REMEDIES (PER BOX).

Mange Cure................. \$.50 Sure Shot Capsules......\$ .50 Condition Pills, large.. 1.00 Rheumatic Pills............ .50 Condition Pills, small.. .50 Flea Remedy, bot.......... .25 Iron and Arsenic Pills, large 1.00

Iron and Arsenic Pills, $\begin{array}{ll}\text { Flea Remedy, bot......... } & .25 \\ \text { Canker Wash, bot........ } & .50\end{array}$ Arsenic Pils, 50 Constipation Cure....... .25 Sure Shot Liquid, bot. .50 Soft Carbolic Soap..... .25 We are agents for the above. well known remedies. If interested in bogs and their diseases, write for "Free Booklet.'

Spratt's Dog Soap, 25c cake; dozen............................\$1.75 Lister's Dog Soap, $10 \mathrm{c}$ cake; dozen...

1.00

Spratt's Meat Fibrine Vegetable Dog Cakes-The standard dog food. Used at the leading kennels and dog shows throughout the world, a staple and constant food for all breeds of dogs.

Bulk, $100-\mathrm{lb}$. boxes, $\$ 12.00 ; 3 / 4-\mathrm{lb}$. carton, $20 \mathrm{c} ; 2 \frac{1}{2}-\mathrm{lb}$. carton, 40c; 5-lb. carton, $75 \mathrm{c}$.

Spratt's Puppy Biscuits-The standard puppy food. A perfect and whole food for puppies of all breeds. Follow directions on each package. Bulk, 100-lb. boxes, $\$ 12.00$; $3 / 4-1 \mathrm{lb}$. carton, 20c; $21 / 2-1 \mathrm{~b}$. carton, $40 \mathrm{c} ; 5-1 \mathrm{~b}$. carton, $75 \mathrm{c}$. Prepared Canned Meat-2 $1 / 2-1 b$ cans. An Ideal Dog Food., very convenient, never spoils. One can, $50 \mathrm{c}$; dozen, $\$ 4.00$.

Weanol-The perfect substitute for bitch's milk. This is an ideal preparation for raising puppies that have los their mother. There is nothing that has ever been offered on the market for this purpose. Price, per can, $\$ 1.00$.

\section{DAIRY SUPPLIES.}

Milk Bottles (Standard Weight).

Doz. Gross Doz. Gross

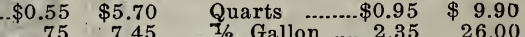
OSBORN MTLK CAN BRUSHES-No. 08. Price, 35c. MILK BOTTLE AND JAR BRUSHES-No. 86; each, $\$ 0.40 ;$ dozen, $\$ 4.00$

MILK BOTTLE CAPS-Regular, per box of $5,000, \$ 2.10$ Certified, per box $5,000, \$ 2.60$. Special prices made in large quantities. Can furnish printed in any style wanted. MILK BOTTLE CARRIERS (Galvanized Iron).

6 pt. size, each............\$1.00 6 qt. size, each............. $\$ 1.25$ 8 pt size $150 \quad 8$ qt size, each ............. 2.00 pt. size, each-....... 1.50 8 qt. size, each......... $\$ 5.00$ and 5 gal. Ice DE LAVAL CREAM SEPARATORS.

For more than 30 years this has been the standard Cream Separator of the world. Farm. ers, as well as dairymen, are finding out the advantages of a separator and that they pay for themselves within a year. Sooner or later you will buy a separator, and when you do insist on getting the best. N one keeping two or more cows can afford to be without a separator today, butter you are making with out a separator you can make 4 pounds or more with a De Laval, besides the labor saved. We Carry in StockNo. 5; Capacity guaranteed 135 lbs. per hour $\$ 50.00$ No. 10, Capacity guaranteed $335 \mathrm{lbs}$. per hour .....\$75.00 No. 12, Capacity guaranteed 450 lbs. per hour .......................... $\$ 85$ 750 , Capacity guaranteed 750 lbs. per hour....\$100.00 No. 101 Turbine..........\$200.0 De Laval Milk Clarifiers
No. 100 ............ $\$ 200.00$ If interested, get special catalog.

Champion Milk Coolers.

No. 2, Capacity 4 gallons, each: No. 3, Capacity 8 gallons, 9.50

No. 4, Capacity 12 gallons, each ....................... 11.50 STERITAC SANITARY MILK PAILS-Most sanitary milk pail known; recommended by the Board of Health. Ten per cent discount on lots of 6 or more. Price-Standard Pails, each................................\$2.50 Price-Seamless Pails, each...................................... 3.00 


\section{DAVIS SWING CHURNS.}

No. 1, 4 gallons or less

No. 1,4 gallons or less

No. 3,8 gallons or less.

No. 4,10 gallons or less

No. 5,13 gallons or less

No. 6, 17 gallons or less.

No. 7, 30 gallons or less.

No. 8, 40 gallons or less.

BUTTER PAPER-Heavily paraffined for wrapping but-

ter. 1 lb., $40 \mathrm{c} ; 10$ to 25 lbs. at $35 \mathrm{c}$ lb.

BUTTER CARTONS-Hold 1 lb. butter. Price, 100 $\$ 1.75$

WYANDOTTE DAIRY CLEANER AND CLEANSERFor Dairy, Hotels, etc.-Barrels, \$5.55; 80-pound kegs, $6 \frac{1}{2} \mathrm{c}$ pound.

- For dairy use, 10 times Sare to use; not poisonous. g milk bottles, churns, separators and killing germs in milk houses, and for use on cow udders. Price, one quart, $\$ 1.00 ; 1$ gallon, $\$ 2.75$. BUTTER COLORING.

15.25

15.50

8.50

19.50
23.50
Wells \& Richardson, bottle, 50c; one-half dozen, $\$ 2.25$

We carry a full line of all Dairy Supplies. Write us for what you want.

Bird Manna

Bird Bitters

Song Restorer .

Plumage Restorer

Bird Eye Water..

Mite Exterminator

Moulting Pepper

Bird Seed (1-lb. packages)

Silver Gravel

Cuttle Fish Bone, per pound

Mixed Bird Seed (bulk) 10 pounds, $20 \mathrm{c}$ pounds, $18 \mathrm{c} ; 100$ pounds, $16 \mathrm{c}$ per pound

We also list and carry in stock a full line of Animal Feeds and Animal Remedies, and Bird Supplies, Cages, etc. Write for our complete Poultry and Pet Stock Supply Catalog.

Wells \& Richardson, bottle, $25 \mathrm{c} ;$ one-half dozen, $\$ 1.25$.

\section{WILLET'S HIGH GRADE TRUCK FERTILIZER}

Ammonia, 7 1-2 per cent.

Phosphoric Acid (available), 4 per cent.

Potash, 21-2 per cent.

The above high-grade goods-71-2, 4, 21-2-are made especially for us and by the best manufacturers in this section, and from high-grade materials-the Ammonia being derived from pigeon manure, Nitrate of Soda and Ground Blood, and Potash is made from the best grade of Western Muriate. Truckers and Gardeners will find this fertilizer to be just what they want for quick, fine-growing spring crops. Every sack is guaranteed to be first-class in every way.

Price, f. o. b. Augusta, small package, 12 pounds

Price, f. o. b. Augusta, 1 sack, 200 pounds

Price, f. o. b. Augusta, 1 ton.

105.00

Price, f. o. b. Savannah, 1 carload of 30 tons, per ton

96.50

NOTE! We can quote low prices cash, ton and carlot, f. o. b. Savannah, on 3-Ammonia, 8-Phos., 3-Pot., and 3-Ammonia, 9-Phos. and 4-Pot. for Cotton and Corn.

\section{NEW THINGS WE STRESS}

We call especial attention to the below things, new, and of high value as found in this catalog:

Japanese Garden Seeds, Hog Goobers, Brown Top Millet, Biloxi Soy Beans, Giant Bermuda, Hairy Peruvian Alfalfa, Georgia Bush Velvet Bean, Winter Beardless Barley, Lewis' 63 Wilt-Resistant Cotton, Whatley Field Corn, Golden Beauty Corn.

Willet's New Wonder Garden Pea-(Received too late for publication in "Garden Peas" in catalog.) New, and a wonder in Garden Peas. Medium late; seed are the same size as First and Best; could be called Winter Pea, for they can be planted in December and January; will stand more cold than any other pea. Vine is dark. Very few seed are necessary for planting a given area. Plant one pea every four or five inches in single rows (never in double rows). Its remarkable quality is that each seed stools four to ten times - there being these many stems to each seed. Dwarf; does not need sticking. Spreads out in the row almost as wide as it is high. The most prolific of all Garden Peas. It originated here at Augusta about ten years ago, but has not been commercially sold. Our grower this year after marketing through a long season his green peas then gathered twenty bushels of dry peas on one acre. Without doubt it is the best trucking pea today in the South. Stock very limited, and we are only listing it in order to introduce it in a small way this year. PRICE-One Pint, 75c; one quart, \$1.25. 


\section{THE FRUIT TREE INDUSTRY}

\section{ORCHARD FRUITS; SIMALL FRUITS; ORNAMENTALS; NUTS AND OTHER TREES}

The N. L. Willet Seed Company have intimate connection with three large nursery tree companies, wholesale (Tennessee and Alabama). We offer our services to those who want reliable goods.

State your wants.

\section{TO THE COMIMERCIAL PEACH GROWER:}

We are agents for the largest wholesale exclusive Peach Nursery in the South. In lots of from 500 to 1,000 trees we can quote, quick acceptance at amazing low prices on the following types: Mayflower, Greensboro, Gordon (Uneda), Red Bird Cling. (Early Rose), Arp, Beauty, Dixie Queen, Carman, Elberta, Hale, Hiley, Belle of Georgia-given here in order of ripening season.

\section{TO THE HOMF FRUIT GROWER:}

We are agents for the two largest. Wholesale Nurseries in the South growing assorted fruit and ornamental tree and shrub types, and can make you lowest prices. Tell us your wants in-

ORCHARD FRUITS-Peaches, Apples, Pears, Japanese Plums, Cherries, Quinces, Mulberries, Figs, Japanese Persimmons, Fruit Pomegranates, etc.

SMALL FRUITS-Currants, Raspberries, Blackberries, Dewberries, Grapes, Strawberries, etc.

NUTS-Pecan, Black Walnut, English Walnut, etc.

SUNDRIES-Evergreens, Amoor River Privets, Trifoliata, Roses, Peonies, Flowering Shrubs, Shade and Ornamental Trees, etc.

\section{ADDRESS: N. L. WILLET SEED COIMPANY, AUGUSTA, GEORGIA}




\section{N. L. Willet Seed Company, Augusta, Ga. MANUFACTURERS}

RUTHLESS INSECT EXTERMINATOR-Pleasant Odored Liquid, sprayed is best preparation as yet known for Mosquitoes when sprayed in the room at night; for Dog Fleas, Argentine Ants and House Flies. Do not spray on cats. Use No. 1 for the above purposes.

PRICES-Full pints (16 oz.) with mouth sprajer, $40 \mathrm{c}$; full quarts (32 oz.) with mouth sprayer, $60 \mathrm{c}$; one gallon can with 1 quart sprayer, $\$ 1.75 ; 5$-gallon can with 1 quart sprayer, $\$ 1.60$ per gallon; 10 -gallon can with 1 quart, $\$ 1.50$ per gallon; $1 / 2$ barrel with 1 gallon sprayer at $\$ 1.35$ per gallon; 1 barrel with 1 gallon "Business"' sprayer free, at $\$ 1.25$ per gallon.

RUTHLESS INSECT EXTERMINATOR-No. 2. Same as No. 1 , but heavier-bodied for use against flies, etc., on dairy cows, horses, etc., in the fields or in the stables. Price: Same as No. 1.

HOUSEHOLD CLEANSING FLUID removes spots, grease, oil, fats, varnish, paints. Harmless to fabric or colors. Odorless and non-inflammable-better than Benzine. Price: 1-lb. tins $50 \mathrm{c}$; postpaid $60 \mathrm{c} ; 5$-lb. tins $\$ 1.75$; postpaid, $\$ 2.00$.

CARTWRIGHT'S DOG MANGE CURE, liquid form, or in powder form (same as our liquid). This is the only Mange Cure in powder and which can be mailed, as put up in the United States. Price: Liquid, 50c; Powder, 50c postpaid, $55 \mathrm{c}$. Guaranteed or money refunded. This remedy cured all the mangy dogs out of several hundred impounded this past season in Augusta. A wonderful discovery for the quick and absolute cure of Mange, the scourge of the kennel and dread of the dog-owner everywhere.

CARTWRIGHT'S BLACK TONGUE REMEDY, for Black Tongue and Hook-Worm in dogs. One package contains symptoms and the complete remedy, including a box of Dog Tonic Pills for convalescence. Dry form, 1 package, postpaid, $\$ 1.00$. Get literature.

SYMPTOMS-Paleness of tongue and mouth, which finaily become black, abnormal appetite for the eating of dirt and clay, cough and vomiting, dribbling of thick and ropy saliva, champing of jaws (most cases of supposed rabies are simply Black Tongue), sore mouth, loss of appetite and inability to swallow, breath, vomits and excrements of bloody mucus and bile offensive, skin hide-bound, weakness of legs and hindquarters, and great weakness which increases up to death.

CARTWRIGHT'S DOG SOAP-1 cake 20c; postpaid, 25 c; 1 box 3 cakes for 60 c postpaid.

ANIMAL PARASITE KILLER-Carries strength even greater than that of carbolic acid. Mix one part to twentyfive of water. Kills fleas, lice, mites, itch and mange. One pint, 30c; 1 quart, $50 \mathrm{c} ; 1$ gallon, $\$ 1.25 ; 5$ gallons at $\$ 1.00$, and 10 gallons at $85 \mathrm{c}$ per gallon-cans extra.

SUN SANITARY FLUID-Mix one part to fifty of water. An ideal disinfeçtant, deodorizer, and antiseptic, for dwellings, stables, poultry houses, etc. About $2 \frac{1}{2}$ times stronger than crude carbolic acid. One pint, 20c; 1 quart, $35 \mathrm{c} ; 1$ gallon, $\$ 1.00 ; 5$ gallons at $85 \mathrm{c}$ and 10 gallons at $75 \mathrm{c}$ per gallon-cans extra.

CONTAGION RAT DEATH-A germ fed on bread gives rat or mouse eating it (hurtful to no other animal) a contagious disease fatal in ten days and which he spreads to the whole tribe. The rat is mummified and is odorless when dead. One box, 50c postpaid.

WILLET'S RAT AND ROACH POISON-A poison for rats, mice and cock roaches. A paste in collapsible tubes.
Press the tube and the poison spreads itself. Two oz. to the tube. We guarantee this to give satisfaction. $25 \mathrm{c}$ postpaid.

COTTON MARKING AND BRANDING INK-"Rex Brand',-Colors, Green, Blue, Red, Purple, Black (powder); simply mix in water), pkg. for 50 gal. Ink $\$ 5.00$; postpaid, $\$ 5.15$; for 25 gal. $\$ 2.75$; postpaid $\$ 2.85$, and 10 gal. $\$ 1.50$; postpaid $\$ 1.60$. Fadeless Blue,, pkg. for 25 gal. Ink (no smaller size), 3.50 ; postpaid $\$ 3.60$.

COTTON BRANDING BRUSHES-With Handles, $50 \mathrm{c}$ each; postpaid $60 \mathrm{c} ; 1$ dozen $\$ 4.50$.

COTTON MARKING BRUSHES-Sterling No. $3 \$ 1.00$, and Mobile $\$ 2.50$; No. $37830 \mathrm{c}$, and $37740 \mathrm{c}$ postpaid.

COTTON STENCILS-In tin only. State your wants.

COTTON BALE TAGS-Numbered inseriatim and with detachable coupon. Get prices and literature.

\section{'WILLET'S FARM MACHINERY.}

No. 5 "DIXIE" VELVET BEAN AND PEA HULLER -Hulls Velvet Beans fro mthe Dry Pod. Hulls Cow Peas from the Dry Pod. CAPACITY-20 to 30 bushels per hour. Operated by $3 \mathrm{H}$. P. engine or motor. Weight 650 pounds. This is the most successful Velvet Bean Huller on the market. State whether wanted to hull the Hundred-Day or the large Chinese and Osceola Velvet Beans. We have had nearly 20 years' experience in Velvet Bean Machines, and this is the most successful machine known today. Price, $\$ 140.00$.

\section{CANNING CUTFITS AND DEHYDRATORS.}

EL FLOR CANNERS-No. 14 (for 14-qt. Jars), price $\$ 5.50$; Nos. 21 and 24 (for 24-qt. Jars), price $\$ 12.50 ;$ No. 30 (30-qt. Jars), $\$ 17.50$; No. 64 (64-qt. Jars), $\$ 33.00$. TWe carry also Tin Cans; Canning Accessories.

COMMERCIAL DEHYDRATORS-Powerful satisfactory. Rigidly constructed. Draft is uniformly distributed. Capacity per day 16 bushels, fruits or vegetables- $\$ 125.00$.

KITCFIEN DEHYDRATORS-Get prices for these smaller Evaporators. Circular letters on all above furnished on application.

CAROLINA COTTON SEED GRADER-The only machine we have ever found that will do rapid work and will clean successfully big cotton seed, little seed, black seed, runty seed and trash, and leave you a homogeneous seed of the size as wanted.

In planting the ungraded seeds, the smaller seeds and the black seeds will always come up first and at cottonchopping time will be the most advanced plants, and these most undesirable and unwanted plants will be the very ones that will be left. The farmer can not afford this; in these days of high-priced cotton and Boll Weevil, the man who plants an acre in cotton wants to get and must get the very highest outturn possible from this acre. It is impossible to do this without a Cotton Seed Grader. Price of the above machine $\$ 50.00$ Augusta.

WILLET'S FARM MACHINERY-Master's Plant Setter, $\$ 5.50$; Carolina Cotton Seed Grader, $\$ 50.00$; Tom Huston Peanut Sheller, $\$ 6.00$, factory; Tom Huston Peanut Digger, $\$ 3.50$ delivered; Black Hawk Grist Mill, \$3.50; Black Hawk Corn Sheller, $\$ 2.50$; Bostrom Improved Farm Level, $\$ 20.00$; Dixie Velvet Bean Huller, No. 5, \$140.00; Cyclone Seed Sower, $\$ 2.00$; Perfection Garden Drill and Seeder, $\$ 2.25$; Monarch Duster (cotton, tobacco, potatoes, etc.), $\$ 15.00$. 
WILLET'S SPRING 1919 CATALOGUE FOR GARDENERS, TRUCKERS AND FARMERS. AN ENCYCLOPEDIA AS CONCERNING SOUTHERN SEEDS FOR SPRING AND SUMMER PLANTING

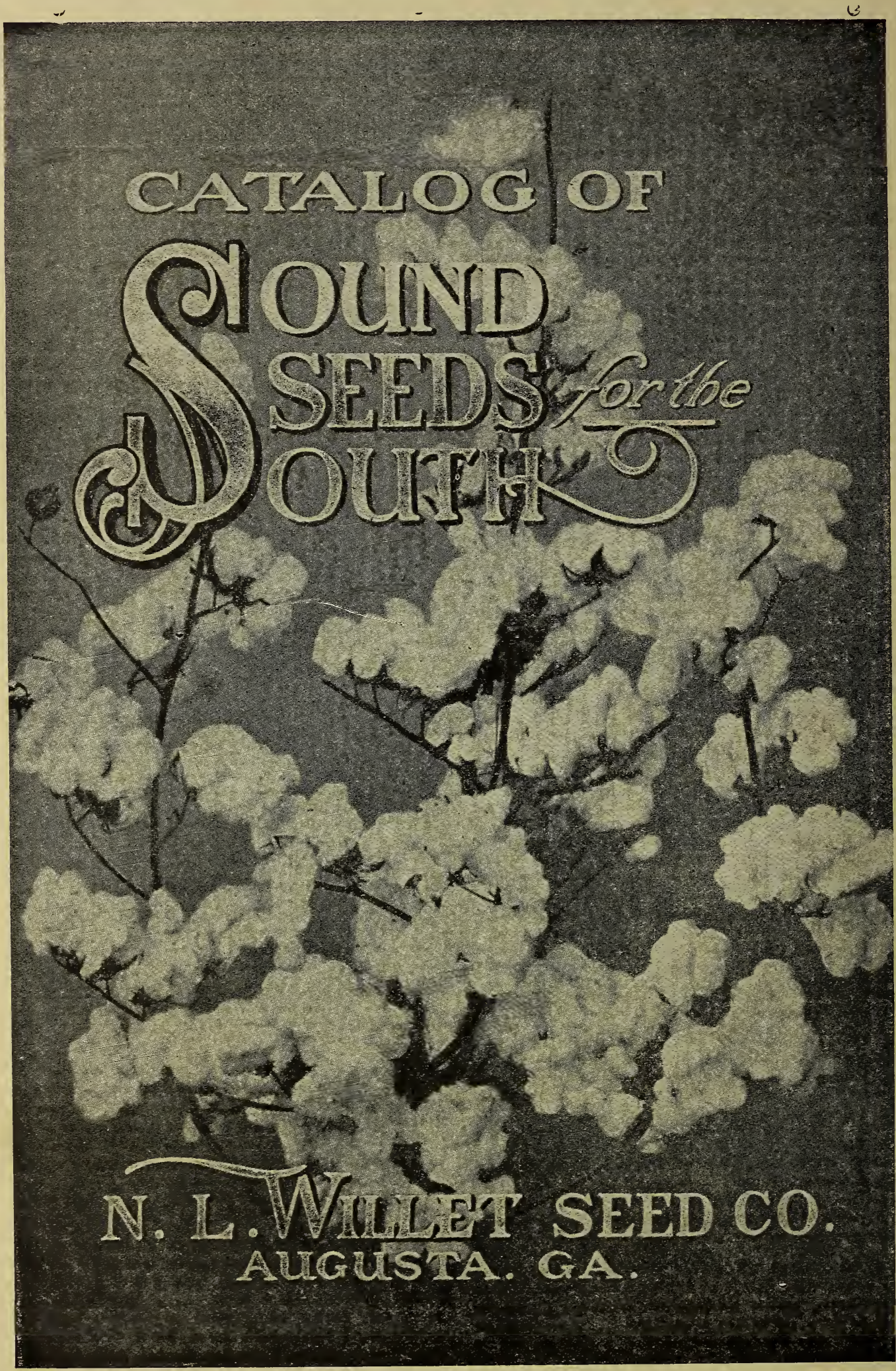

A Stalk of Willet's "Ideal" Cotton seed.

NOTE! The farmer who wishes to divergify his crops in 1919, should read this catalog as a whole. It will put him in the way for Mixed Home-Feeding Farming. After reading, hang it up! 